National Water-Quality Assessment Program Transport of Anthropogenic and Natural Contaminants (TANC) to Public-Supply Wells

\title{
Aquifer Chemistry and Transport Processes in the Zone of Contribution to a Public-Supply Well in Woodbury, Connecticut, 2002-06
}

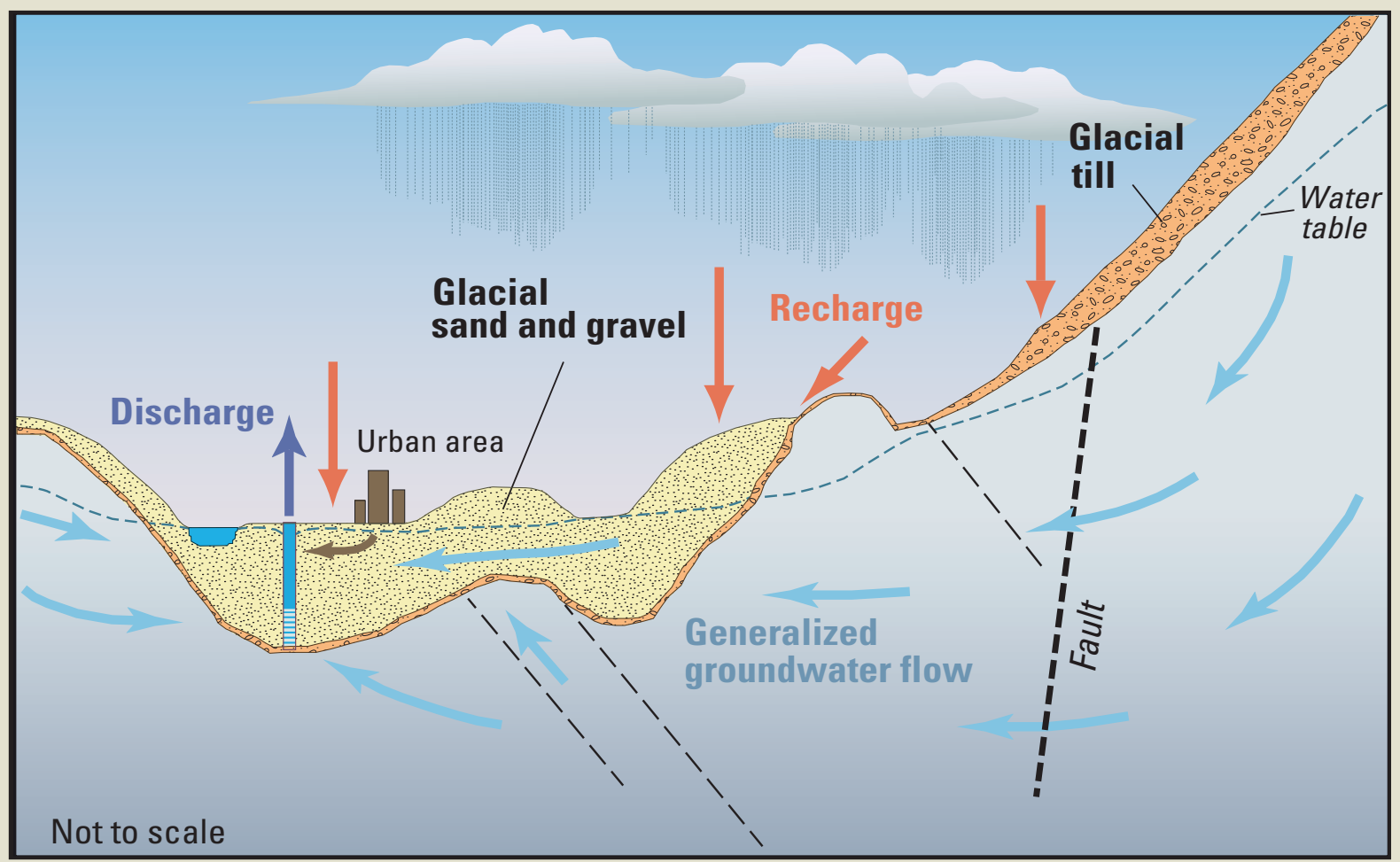

Scientific Investigations Report 2009-5051 
This page has been left blank intentionally. 


\section{National Water Quality Assessment Program}

\section{Aquifer Chemistry and Transport Processes in the Zone of Contribution to a Public-Supply Well in Woodbury, Connecticut, 2002-06}

By Craig J. Brown, J. Jeffrey Starn, Kenneth G. Stollenwerk, Remo A. Mondazzi, and Thomas J. Trombley

Scientific Investigations Report 2009-5051 


\title{
U.S. Department of the Interior \\ KEN SALAZAR, Secretary \\ U.S. Geological Survey \\ Marcia K. McNutt, Director
}

\section{U.S. Geological Survey, Reston, Virginia: 2009}

\author{
For more information on the USGS — the Federal source for science about the Earth, its natural and living resources, \\ natural hazards, and the environment, visit http://www.usgs.gov or call 1-888-ASK-USGS \\ For an overview of USGS information products, including maps, imagery, and publications, \\ visit http://www.usgs.gov/pubprod \\ To order this and other USGS information products, visit http://store.usgs.gov
}

\begin{abstract}
Any use of trade, product, or firm names is for descriptive purposes only and does not imply endorsement by the U.S. Government.

Although this report is in the public domain, permission must be secured from the individual copyright owners to reproduce any copyrighted materials contained within this report.
\end{abstract}

Suggested citation:

Brown, C.J., Starn, J.J., Stollenwerk, K.G., Mondazzi, R.A., and Trombley, T.J., 2009, Aquifer chemistry and transport processes in the zone of contribution to a public-supply well in Woodbury, Connecticut, 2002-06: U.S. Geological Survey Scientific Investigations Report 2009-5051, 158 p. Also available at http://pubs.usgs.gov/sir/2009-5051/. 


\section{Foreword}

The U.S. Geological Survey (USGS) is committed to providing the Nation with credible scientific information that helps to enhance and protect the overall quality of life and that facilitates effective management of water, biological, energy, and mineral resources (http://www.usgs. gov/). Information on the Nation's water resources is critical to ensuring long-term availability of water that is safe for drinking and recreation and is suitable for industry, irrigation, and fish and wildlife. Population growth and increasing demands for water make the availability of that water, now measured in terms of quantity and quality, even more essential to the long-term sustainability of our communities and ecosystems.

The USGS implemented the National Water-Quality Assessment (NAWQA) Program in 1991 to support national, regional, State, and local information needs and decisions related to water-quality management and policy (http://water.usgs.gov/nawqa). The NAWQA Program is designed to answer: What is the condition of our Nation's streams and groundwater? How are conditions changing over time? How do natural features and human activities affect the quality of streams and groundwater, and where are those effects most pronounced? By combining information on water chemistry, physical characteristics, stream habitat, and aquatic life, the NAWQA Program aims to provide science-based insights for current and emerging water issues and priorities. From 1991-2001, the NAWQA Program completed interdisciplinary assessments and established a baseline understanding of water-quality conditions in 51 of the Nation's river basins and aquifers, referred to as Study Units (http://water.usgs.gov/nawqa/studyu.html).

In the second decade of the Program (2001-2012), a major focus is on regional assessments of water-quality conditions and trends. These regional assessments are based on major river basins and principal aquifers, which encompass larger regions of the country than the Study Units. Regional assessments extend the findings in the Study Units by filling critical gaps in characterizing the quality of surface water and groundwater, and by determining status and trends at sites that have been consistently monitored for more than a decade. In addition, the regional assessments continue to build an understanding of how natural features and human activities affect water quality. Many of the regional assessments employ modeling and other scientific tools, developed on the basis of data collected at individual sites, to help extend knowledge of water quality to unmonitored, yet comparable areas within the regions. The models thereby enhance the value of our existing data and our understanding of the hydrologic system. In addition, the models are useful in evaluating various resource-management scenarios and in predicting how our actions, such as reducing or managing nonpoint and point sources of contamination, land conversion, and altering flow and (or) pumping regimes, are likely to affect water conditions within a region.

Other activities planned during the second decade include continuing national syntheses of information on pesticides, volatile organic compounds (VOCs), nutrients, selected trace elements, and aquatic ecology; and continuing national topical studies on the fate of agricultural chemicals, effects of urbanization on stream ecosystems, bioaccumulation of mercury in stream ecosystems, effects of nutrient enrichment on stream ecosystems, and transport of contaminants to public-supply wells. 
The USGS aims to disseminate credible, timely, and relevant science information to address practical and effective water-resource management and strategies that protect and restore water quality. We hope this NAWQA publication will provide you with insights and information to meet your needs, and will foster increased citizen awareness and involvement in the protection and restoration of our Nation's waters.

The USGS recognizes that a national assessment by a single program cannot address all water-resource issues of interest. External coordination at all levels is critical for cost-effective management, regulation, and conservation of our Nation's water resources. The NAWQA Program, therefore, depends on advice and information from other agencies-Federal, State, regional, interstate, Tribal, and local—as well as nongovernmental organizations, industry, academia, and other stakeholder groups. Your assistance and suggestions are greatly appreciated

Matthew C. Larsen

Associate Director for Water 


\section{Contents}

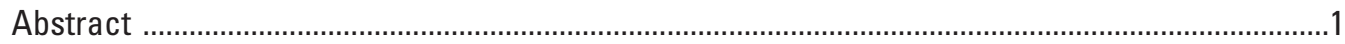

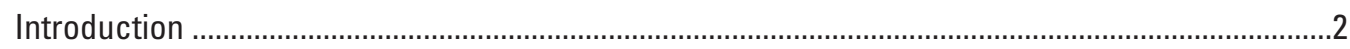

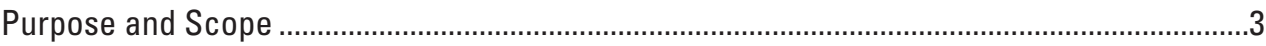

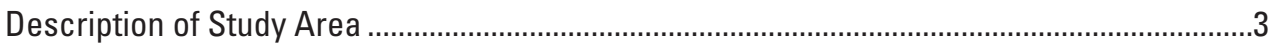

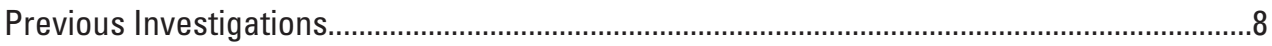

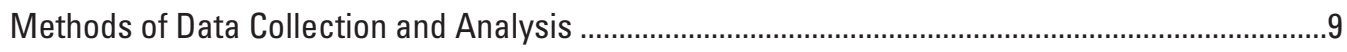

Design of Well Network ...............................................................................................

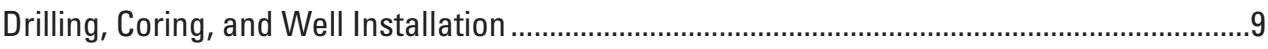

Analysis of Glacial Deposits and Bedrock ..........................................................................

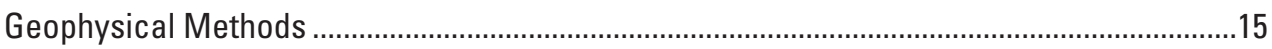

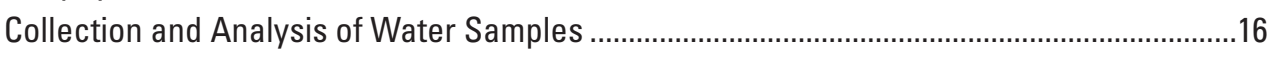

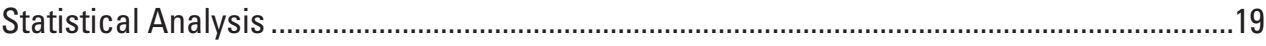

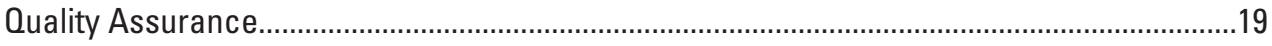

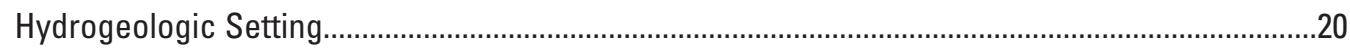

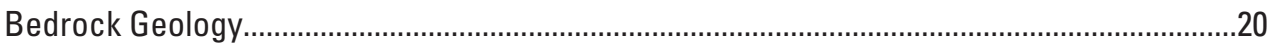

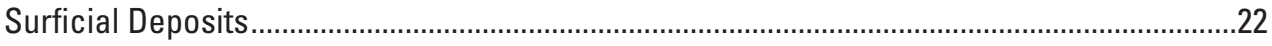

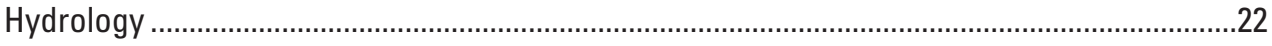

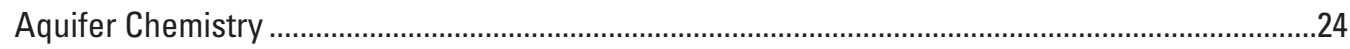

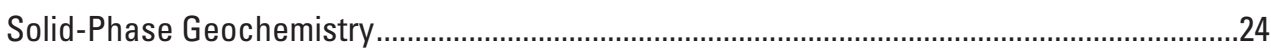

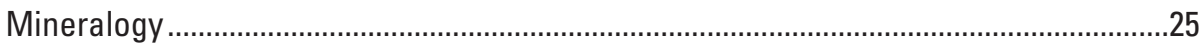

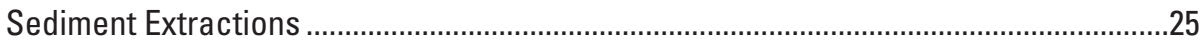

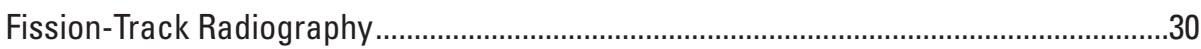

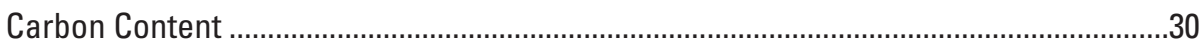

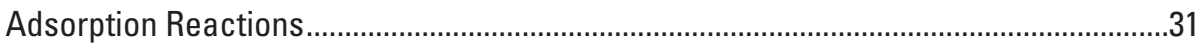

Groundwater Chemistry..................................................................................................

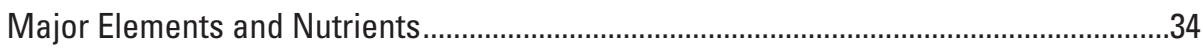

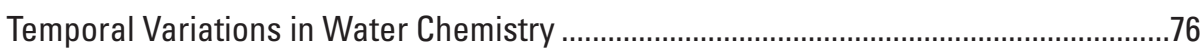

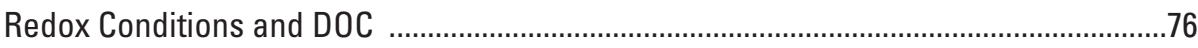

Naturally Occurring Constituents of Concern..................................................................81

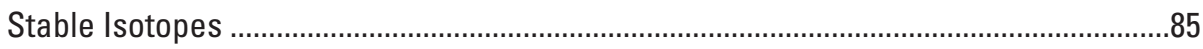

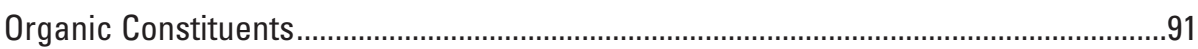

Volatile Organic Compounds...............................................................................92

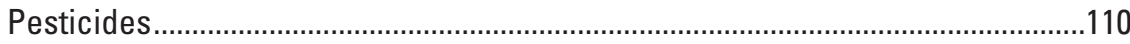

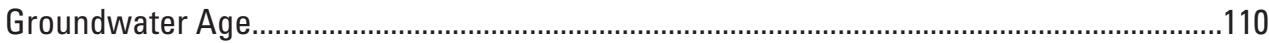

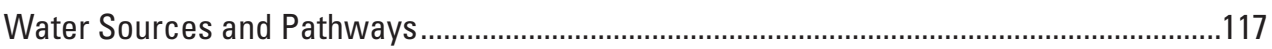

Factors Affecting the Water Chemistry at the Public-Supply Well .......................................121

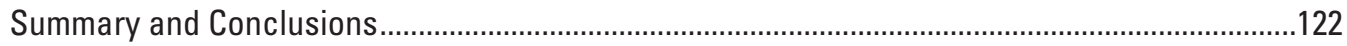

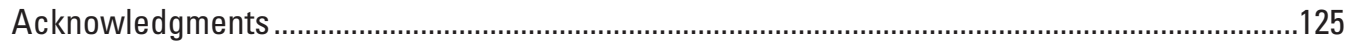

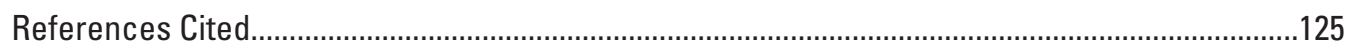

Appendix 1. Depths of sediment and rock samples and description of texture and lithology, color, and sorting, from monitoring-well boreholes in the study area, Woodbury,

Connecticut. 
Appendix 2. Gamma, fluid temperature, fluid conductivity, and caliper logs, and acoustic travel time, acoustic televiewer amplitude, and optical televiewer images for bedrock monitoring wells WY86 (2-1), WY87 (2-2), WY97 (2-3), and WY106 (2-4) in relation to depth in the study area, Woodbury, Connecticut.....

Appendix 3. Quality-control summary for constituents detected in field blanks and percent recovery for surrogates in the study area, Woodbury, Connecticut, 2003-05 152

Appendix 4. Oxidation-reduction (redox) classification scheme developed for the transport of anthropogenic and natural contaminants to public-supply wells 154

\section{Figures}

1. Map showing locations of the regional- and local-scale areas for the study of the transport of anthropogenic and natural contaminants (TANC) to public-supply wells, monitoring and supply wells used for this study in Connecticut, and the glacial stratified deposits in the Connecticut, Housatonic, and Thames River Basins (CONN) study unit and surrounding area.

2. Map showing modeled area showing wells, geologic materials, altitude of top of bedrock, lines of hydrogeologic section, and the contributing recharge area to the public-supply well (PSW-1) in the study area, Woodbury, Connecticut

3. Diagrams showing hydrogeologic sections showing locations and identifiers of wells installed in thestudy area, Woodbury, Connecticut.

4. Map showing $(A)$ land use/land cover for 2002 with Significant Potential Contaminant Sources, simulated paths of flow to monitoring wells, and the modeled contributing recharge area to well PSW-1 based on particle tracking with MODPATH, and (B) methyl-tert-butyl ether (MTBE) concentrations, in parts per billion ( $\mathrm{ppb}$ ), in samples collected September 8, 2004, from wells of shallow (less than 6 meters) and intermediate (about 9 meters) depths, Woodbury, Connecticut ........7

5. Diagram showing construction and lithology at public-supply well PSW-1, and screened intervals for PSW-1 and adjacent monitoring wells WY100, 101, 102, 103, and 106, Woodbury, Connecticut

6. Diagram showing construction and lithology at monitoring wells WY91 and 92, and multilevel samplers WY92c and WY92e, Woodbury, Connecticut.

7. Map showing bedrock geology of the Pomperaug and Connecticut structural basins and the study area, and simulated paths of flow to monitoring wells and the modeled contributing recharge area to PSW-1 based on particle tracking with MODPATH, Woodbury, Connecticut

8. Diagram showing selected groundwater characteristics measured in well WY103, May 2005, with a water-quality monitor, and October 2004, with borehole geophysical tools, in relation to altitude, Woodbury, Connecticut

9. Photographs showing optical microscope images of a sample of glacial deposits from 17 meters depth from land surface at borehole WY75, showing (A) an iron-oxide grain, and (B) fission tracks recorded after irradiation with uranium-235 on the same sample, Woodbury, Connecticut.

10. Graph showing concentrations of (A) arsenic (V) in water as a function of arsenic sorbed, and (B) uranium (VI) in water as a function of uranium sorbed, based on column experiments of core sediments from WY83 (7.3 meters depth below land surface), WY90 (6.7 meters depth below land surface), WY92 (3.7 meters depth below land surface), WY94 (4.3 meters depth below land surface), and WY100 (4.8 meters depth below land surface), and simulated sorption for these samples using PHREEQC 
11. Graph showing specific conductance as a function of depth of well screen below land surface for groundwater samples from wells in the Woodbury study area, and from selected wells elsewhere in the Pomperaug and Hartford Basins, Connecticut

12. Diagram showing distribution of $(\mathrm{A}) \mathrm{pH}$, and (B) bicarbonate concentrations in groundwater samples from well screens in the (1) shallow parts of the glacial aquifer, greater than 3 meters above bedrock, (2) deep glacial aquifer, less than 3 meters above bedrock, (3) shallow bedrock, less than 30 meters below bedrock surface, and (4) deep bedrock, greater than 30 meters below bedrock surface in the study area, Woodbury, Connecticut.

13. Piper diagram showing the percentage of total equivalents of major cations and anions in groundwater samples from wells in the Woodbury study area, and from selected wells elsewhere in the Pomperaug and Hartford Basins, Connecticut

14. Diagram showing concentrations of $(A)$ magnesium as a function of calcium, and (B) chloride as a function of sodium, in groundwater samples from wells in the Woodbury study area, and from selected wells elsewhere in the Pomperaug and Hartford Basins, Connecticut.

15. Graph showing concentrations of $(A)$ magnesium as a function of calcium, and (B) chloride as a function of sodium, in groundwater samples from wells in the Woodbury study area, and from selected wells elsewhere in the Pomperaug and Hartford Basins, Connecticut.

16. Graph showing concentrations of chloride as a function of chloride:bromide mass concentration ratios in samples collected in the Woodbury study area, Connecticut, and in other studies, together with mixing lines between designated end points, dilute groundwater, halite, sewage, and seawater.

17. Graph showing concentrations of nitrate plus nitrite as a function of chloride/bromide mass concentration ratios in groundwater samples in the Woodbury study area, and from selected wells elsewhere in the Pomperaug and Hartford Basins, Connecticut. Symbols are color coded for the estimated relative dissolved organic carbon (DOC) source and strength.

18. Graph showing concentration of nitrate plus nitrite as a function of $(A)$ well depth, and (B) concentration of dissolved organic carbon, in groundwater samples from wells in the Woodbury study area, and from selected wells elsewhere in the Pomperaug and Hartford Basins, Connecticut. Symbols are color coded for the estimated relative dissolved organic carbon (DOC) source and strength.

19. Diagram showing hydrogeologic sections showing medians, and selected ranges, of dissolved oxygen concentrations in groundwater samples from wells in the study area, Woodbury, Connecticut.

20. Graph showing concentrations of dissolved organic carbon (DOC) as a function of the concentration of electron acceptor indicators, including dissolved (A) oxygen, (B) nitrate plus nitrite, (C) manganese, (D) iron, (E) sulfate, and (F) hydrogen sulfide, in groundwater samples from wells in the study area, Woodbury, Connecticut

21. Diagram showing distributions of concentrations of (A) dissolved organic carbon (DOC) and nitrate plus nitrite, and (B) dissolved boron (B) and manganese (Mn), in groundwater samples from wells in relation to the group of wells (1) not apparently affected by abundant natural organic matter or septic-system leachate (background), (2) affected primarily by abundant natural organic matter, and (3) affected primarily by septic-system leachate in the Woodbury study area 
22. Graph showing concentrations of dissolved (A) arsenic, (B) uranium, (C) radium-226, (D) radium-228, and (E) radon-222 in groundwater samples from wells as a function of distance from the well screen to the bedrock interface in the Woodbury study area, and from selected wells elsewhere in the Pomperaug and Hartford Basins, Connecticut.

23. Graph showing concentrations of dissolved arsenic as a function of $(A)$ dissolved oxygen (DO), and (B) dissolved organic carbon (DOC), and concentrations of dissolved uranium as a function of (C) $\mathrm{pH}$, and (D) bicarbonate in groundwater samples from wells in the Woodbury study area, and from selected wells elsewhere in the Pomperaug and Hartford Basins, Connecticut.

24. Graph showing dissolved concentrations of $(A)$ strontium as a function of vanadium, and (B) boron as a function of cobalt, in groundwater samples from wells in the Woodbury study area, and from selected wells elsewhere in the Pomperaug and Hartford Basins, Connecticut.

25. Graph showing $(A)$ isotope values of delta oxygen-18 as a function of delta hydrogen-2 for samples of groundwater and surface water, and (B) concentrations of dissolved sulfate as a function of delta sulfur-34 of sulfate for samples of groundwater, collected in the Woodbury study area, and from selected wells elsewhere in the Pomperaug and Hartford Basins, Connecticut.

26. Graph showing (A) delta nitrogen-15 as a function of delta oxygen-18 values, and (B) initial nitrate in recharge as a function of initial delta nitrogen-15 values in recharge, corrected for denitrification

27. Diagram showing concentrations of $(A)$ the 20 most frequently detected volatile organic compounds, and (B) the seven most frequently detected pesticides, in groundwater samples from each well site in the Woodbury study area, and from selected wells elsewhere in the Pomperaug Basin, Connecticut.

28. Graph showing (A) apparent groundwater age as a function of estimated groundwater recharge temperature, (B) apparent groundwater age as a function of terrigenic helium-4 $\left({ }^{4} \mathrm{He}\right)$ percentage, and (C) the tritium/initial tritium $\left({ }^{3} \mathrm{H} /{ }^{3} \mathrm{H}_{(0)}\right)$ concentration ratio plotted as a function of concentrations of helium-3 $\left({ }^{3} \mathrm{H}\right)$, with modeled curves for various groundwater age distributions for groundwater samples from wells in the study area, Woodbury, Connecticut

29. Graph showing (A) the tritium/initial tritium $\left({ }^{3} \mathrm{H} /{ }^{3} \mathrm{H}_{(0)}\right)$ concentrations as a function of sulfur hexafluoride $\left(\mathrm{SF}_{6}\right)$ concentrations, with modeled curves for various groundwater age distributions, and $(\mathrm{B})$ sulfur hexafluoride $\left(\mathrm{SF}_{6}\right)$ concentrations as a function of terrigenic helium-4 $\left({ }^{4} \mathrm{He}\right)$ concentrations, in groundwater samples from wells in the study area, Woodbury, Connecticut

30. Graph showing average simulated mean traveltimes of groundwater to wells based on particles in MODPATH as a function of the number of volatile organic compounds (VOCs) detected in groundwater samples from wells in the study area, Woodbury, Connecticut

31. Graph showing apparent groundwater age as a function of the (A) silica saturation index and (B) calcite saturation index, in groundwater samples from wells in the study area, Woodbury, Connecticut. 


\section{Tables}

1. Data on the construction of wells in the Woodbury study area, and in selected wells elsewhere in the Pomperaug and Hartford Basins, Connecticut.

2. Classes of water-quality chemical characteristics and constituents measured in water samples from the Woodbury, Connecticut, study area for the flow-path, source-well, and stream-sampling analyte schedules, October 2002 to July 2006.........17

3. Relative mineralogical abundances, based on $x$-ray diffraction (XRD), of core samples from boreholes in the Woodbury, Connecticut, study area, 2003-04. . .26

4. Mineralogy of slightly magnetic and nonmagnetic heavy-mineral separates based on analysis by petrography and spectra of aquifer material from boreholes in the study area, Woodbury, Connecticut, 2003-04.

5. Selected constituents in acid extractions and organic carbon, and analysis of bulk density and pore-water constituents of aquifer material from boreholes in the study area, Woodbury, Connecticut, 2003-04.

6. Results of adsorption experiments on aquifer material sampled in the study area, including $(\mathrm{A})$ the $\mathrm{pH}$, bicarbonate, and surface sorption site concentrations for arsenic (V) and uranium (VI), and (B) equilibrium constants for PHREEOC model of adsorption using experimental data.

7. General chemical characteristics and concentrations of major elements, nutrients, dissolved organic carbon, and ultraviolet absorbance in groundwater samples from wells in the Woodbury study area (2002-06), and from selected wells elsewhere in the Pomperaug and Hartford Basins, Connecticut

8. Dissolved concentrations of trace elements, stable isotope ratios, and radionuclides in groundwater samples from wells in the Woodbury, Connecticut (2002-06), study area, and from selected wells elsewhere in the Pomperaug and Hartford Basins

9. Traveltime in years and percentage of particles in each land-use type for flow-tracking particles backtracked from monitoring-well screens to the water table, simulated with MODPATH (Starn and Brown, 2007)

10. Summary of chloride:bromide mass ratios and concentrations of selected constituents related to road salt (halite) and septic-system leachate in samples from previous studies, and for groundwater samples from selected wells in the Woodbury study area and elsewhere in the Pomperaug Basin, Connecticut.

11. Summary of recharge temperatures determined from dissolved gas concentrations in groundwater samples from wells in the study area, Woodbury, Connecticut, 2003-05.

12. Concentrations of volatile organic compounds and pesticides detected in groundwater samples from wells in the Woodbury study area, and from selected wells elsewhere in the Pomperaug Basin, Connecticut, 2002-05

13. Statistical summary of volatile organic compounds and pesticides detected in groundwater samples from wells in the study area, Woodbury, Connecticut, 2002-05 
14. Summary of tritium/helium-3 $\left({ }^{3} \mathrm{H} /{ }^{3} \mathrm{He}\right)$, sulfur hexachloride $\left(\mathrm{SF}_{6}\right)$, and chlorofluorocarbons (CFC) groundwater age tracer data and apparent ages using a piston flow model for water samples in the study area, Woodbury, Connecticut, 2003-2005

15. Summary of major geochemical sources and the indicative chemical characteristics in the aquifer system of the study area, Woodbury, Connecticut........119

16. Results of inverse geochemical modeling with PHREEOC to determine the relative contribution of high-sulfate groundwater from underlying fractured bedrock, represented by a sample from WY106, to the glacial aquifer, represented by a sample from WY100, in the study area, Woodbury, Connecticut..

17. Results of inverse geochemical modeling with PHREEQC using delta sulfur-34 to determine the relative contribution of groundwater to PSW-1 from various depths represented by adjacent monitoring wells WY102, 100, 101, and 106, in the study area, Woodbury, Connecticut. 


\section{Conversion Factors, Abbreviations, and Datums}

\begin{tabular}{|c|c|c|}
\hline Multiply & By & To obtain \\
\hline \multicolumn{3}{|c|}{ Length } \\
\hline centimeter $(\mathrm{cm})$ & 0.3937 & inch (in.) \\
\hline millimeter (mm) & 0.03937 & inch (in.) \\
\hline meter $(\mathrm{m})$ & 3.281 & foot $(\mathrm{ft})$ \\
\hline kilometer $(\mathrm{km})$ & 0.6214 & mile (mi) \\
\hline \multicolumn{3}{|c|}{ Area } \\
\hline square kilometer $\left(\mathrm{km}^{2}\right)$ & 247.1 & acre \\
\hline square kilometer $\left(\mathrm{km}^{2}\right)$ & 0.3861 & square mile $\left(\mathrm{mi}^{2}\right)$ \\
\hline hectare (ha) & 2.471 & acre \\
\hline \multicolumn{3}{|c|}{ Volume } \\
\hline liter (L) & 0.2642 & gallon (gal) \\
\hline cubic meter $\left(\mathrm{m}^{3}\right)$ & 264.2 & gallon (gal) \\
\hline cubic centimeter & 0.06102 & cubic inch $\left(\right.$ in $\left.^{3}\right)$ \\
\hline \multicolumn{3}{|c|}{ Flow rate } \\
\hline liter per second $(\mathrm{L} / \mathrm{s})$ & 15.85 & gallon per minute (gal/min) \\
\hline cubic meter per day $\left(\mathrm{m}^{3} / \mathrm{d}\right)$ & 264.2 & gallon per day (gal/d) \\
\hline millimeter per year (mm/yr) & 0.03937 & inch per year (in/yr) \\
\hline \multicolumn{3}{|c|}{ Mass } \\
\hline $\operatorname{gram}(\mathrm{g})$ & 0.03527 & ounce, avoirdupois (oz) \\
\hline kilogram (kg) & 2.205 & pound avoirdupois (lb) \\
\hline metric ton per year & 1.102 & ton per year (ton/yr) \\
\hline picomoles per kilogram (pmol/kg) & $1 \times 10^{-9}$ & moles per kilogram \\
\hline femtomoles per kilogram (femtomol/kg) & $1 \times 10^{-12}$ & moles per kilogram \\
\hline \multicolumn{3}{|c|}{ Density } \\
\hline pound per cubic foot $\left(\mathrm{lb} / \mathrm{ft}^{3}\right)$ & 0.01602 & gram per cubic centimeter $\left(\mathrm{g} / \mathrm{cm}^{3}\right)$ \\
\hline \multicolumn{3}{|c|}{ Radioactivity } \\
\hline becquerel per liter $(\mathrm{Bq} / \mathrm{L})$ & 27.027 & picocurie per liter (pCi/L) \\
\hline tritium units (TU) & 3.19 & picocurie per liter $(\mathrm{pCi} / \mathrm{L})$ \\
\hline
\end{tabular}

Temperature in degrees Celsius $\left({ }^{\circ} \mathrm{C}\right)$ may be converted to degrees Fahrenheit $\left({ }^{\circ} \mathrm{F}\right)$ as follows:

$$
{ }^{\circ} \mathrm{F}=\left(1.8 \times{ }^{\circ} \mathrm{C}\right)+32
$$

Temperature in degrees Fahrenheit $\left({ }^{\circ} \mathrm{F}\right)$ may be converted to degrees Celsius $\left({ }^{\circ} \mathrm{C}\right)$ as follows:

$$
{ }^{\circ} \mathrm{C}=\left({ }^{\circ} \mathrm{F}-32\right) / 1.8
$$

Vertical coordinate information is referenced to the North American Vertical Datum of 1988 (NAVD 88).

Horizontal coordinate information is referenced to the North American Datum of 1983 (NAD 83). Altitude, as used in this report, refers to distance above the vertical datum. 
Concentrations of chemical constituents in water or air are given either in milligrams per liter $(\mathrm{mg} / \mathrm{L})$, micrograms per liter $(\mu \mathrm{g} / \mathrm{L})$ or parts per billion $(\mathrm{ppb})$, picograms per liter $(\mathrm{pg} / \mathrm{L})$, molality or moles per liter (M), milligrams per kilogram $(\mathrm{mg} / \mathrm{kg})$, picomoles per kilogram $(\mathrm{pmol} / \mathrm{kg})$, or femtomoles per kilogram (femtomol/kg), or cubic centimeters per liter at standard temperature and pressure ( $\left.\mathrm{cm}^{3} \mathrm{STP} / \mathrm{L}\right)$.

List of Abbreviations

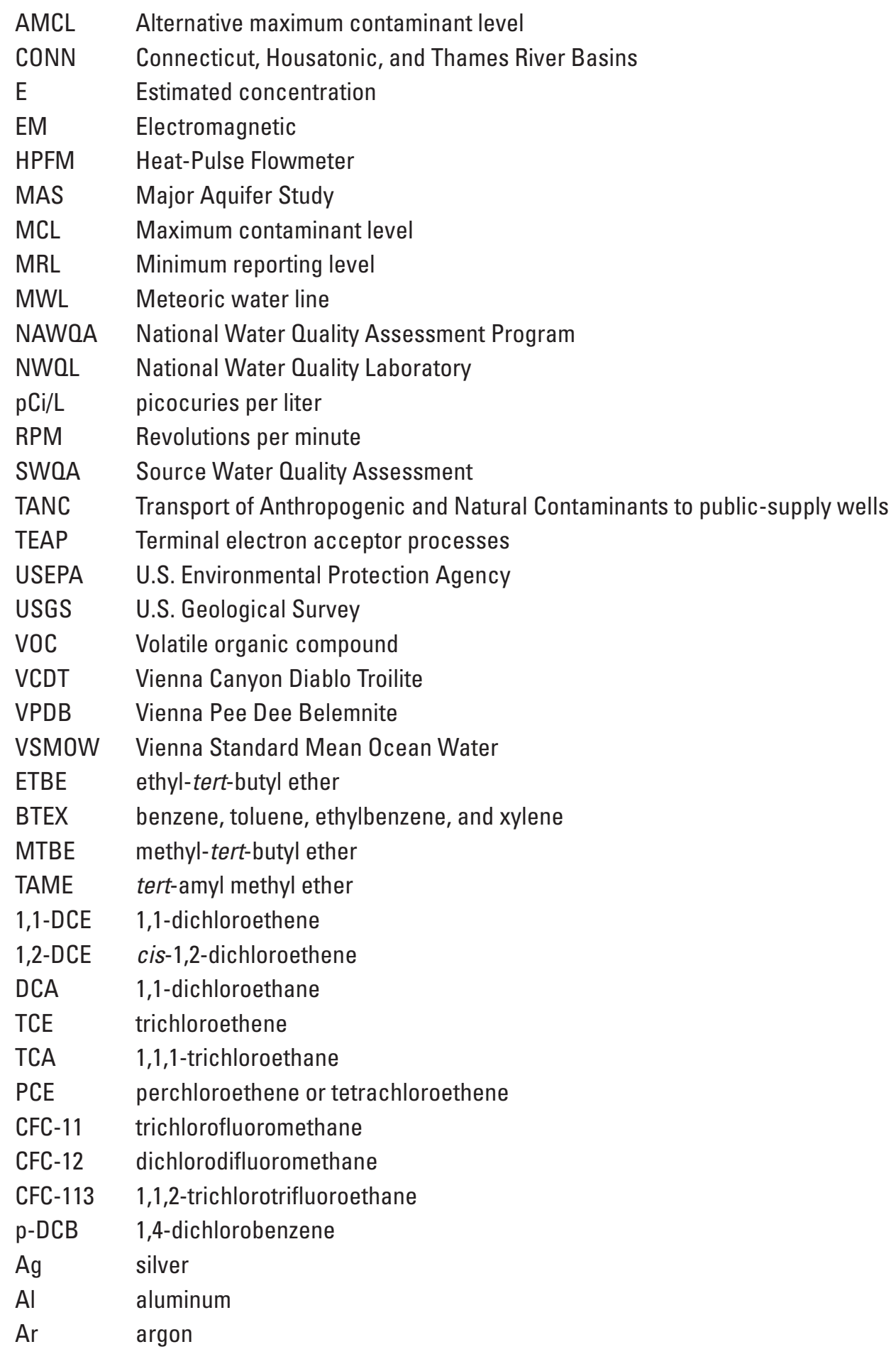




\begin{tabular}{|c|c|}
\hline As & arsenic \\
\hline B & boron \\
\hline $\mathrm{Ba}$ & barium \\
\hline $\mathrm{Be}$ & beryllium \\
\hline $\mathrm{Br}$ & bromine \\
\hline $\mathrm{Br}^{-}$ & bromide \\
\hline C & carbon \\
\hline $\mathrm{Ca}$ & calcium \\
\hline $\mathrm{CaCO}_{3}$ & calcium carbonate \\
\hline $\mathrm{Cd}$ & cadmium \\
\hline $\mathrm{CH}_{4}$ & methane \\
\hline $\mathrm{Co}^{4}$ & cobalt \\
\hline $\mathrm{CO}_{2}$ & carbon dioxide \\
\hline $\mathrm{Cr}$ & chromium \\
\hline $\mathrm{Cu}$ & copper \\
\hline $\mathrm{DO}$ or $\mathrm{O}_{2}$ & dissolved oxygen \\
\hline DIC & dissolved inorganic carbon \\
\hline DOC & dissolved organic carbon \\
\hline $\mathrm{F}^{-}$ & fluoride \\
\hline $\mathrm{Fe}$ & iron \\
\hline $\mathrm{FeS}_{2}$ & iron disulfide \\
\hline $\mathrm{H}$ & hydrogen \\
\hline${ }^{2} \mathrm{H}$ & deuterium, or hydrogen-2 \\
\hline${ }^{3} \mathrm{H}$ & tritium \\
\hline $\mathrm{H}_{2} \mathrm{~S}$ & hydrogen sulfide \\
\hline $\mathrm{H}_{2} \mathrm{~S}, \mathrm{HS}^{-}$ & hydrogen sulfide species \\
\hline $\mathrm{He}$ & helium \\
\hline${ }^{3} \mathrm{He}$ & helium-3 or tritium \\
\hline${ }^{4} \mathrm{He}$ & helium-4 \\
\hline $\mathrm{HCl}$ & hydrochloric acid \\
\hline $\mathrm{HCO}_{3}^{-}$ & bicarbonate \\
\hline $\mathrm{HNO}_{3}$ & nitric acid \\
\hline $\mathrm{H}_{3} \mathrm{PO}_{4}$ & phosphoric acid \\
\hline $\mathrm{K}$ & potassium \\
\hline $\mathrm{Li}$ & lithium \\
\hline Mo & molybdenum \\
\hline $\mathrm{Mg}$ & magnesium \\
\hline $\mathrm{Mn}$ & manganese \\
\hline $\mathrm{N}$ & nitrogen \\
\hline $\mathrm{Na}$ & sodium \\
\hline $\mathrm{Ne}$ & neon \\
\hline $\mathrm{Ni}$ & nickel \\
\hline $\mathrm{NH}_{4}^{+}$ & ammonium \\
\hline $\mathrm{NO}_{2}^{-}$ & nitrite \\
\hline $\mathrm{NO}_{3}^{-}$ & nitrate \\
\hline
\end{tabular}




$\begin{array}{ll}\mathrm{O} & \text { oxygen } \\ \mathrm{P} & \text { phosphorus } \\ \mathrm{Pb} & \text { lead } \\ \mathrm{PO}_{4}^{3-} & \text { phosphate } \\ \mathrm{Ra}^{3-} & \text { radium } \\ \mathrm{Rn} & \text { radon } \\ \mathrm{S} & \text { sulfur } \\ \mathrm{SF}_{6} & \text { sulfur hexafluoride } \\ \mathrm{Se} & \text { selenium } \\ \mathrm{SnCl}_{2} & \text { tin (II) chloride } \\ \mathrm{SO}_{4}{ }^{2-} & \text { sulfate } \\ \mathrm{SiO}_{2} & \text { silica } \\ \mathrm{Sr} & \text { strontium } \\ \mathrm{TI}_{\mathrm{TU}} & \text { thallium } \\ \mathrm{U} & \text { tritium unit } \\ \mathrm{V} & \text { uranium } \\ \mathrm{Zn} & \text { vanadium } \\ & \text { zinc }\end{array}$




\title{
Aquifer Chemistry and Transport Processes in the Zone of Contribution to a Public-Supply Well in Woodbury, Connecticut, 2002-06
}

\author{
By Craig J. Brown, J. Jeffrey Starn, Kenneth G. Stollenwerk, Remo A. Mondazzi, and Thomas J. Trombley
}

\section{Abstract}

A glacial aquifer system in Woodbury, Connecticut, was studied to identify factors that affect the groundwater quality in the zone of contribution to a community public-supply well. Water samples were collected during 2002-06 from the public-supply well and from 35 monitoring wells in glacial stratified deposits, glacial till, and fractured bedrock. The glacial aquifer is vulnerable to contamination from a variety of sources due to the short groundwater residence times and the urban land use in the contributing recharge area to the public-supply well. The distribution and concentrations of $\mathrm{pH}$, major and trace elements, stable isotope ratios, recharge temperatures, dissolved organic carbon (DOC), and volatile organic compounds (VOCs), and the oxidation-reduction (redox) conditions, were used to identify recharge source areas, aquifer source material, anthropogenic sources, chemical processes, and groundwater-flow paths from recharge areas to the public-supply well, PSW-1.

The major chemical sources to groundwater and the tracers or conditions used to identify them and their processes throughout the aquifer system include (1) bedrock and glacial stratified deposits and till, characterized by high $\mathrm{pH}$ and concentrations of sulfate $\left(\mathrm{SO}_{4}^{2-}\right)$, bicarbonate, uranium (U), radon-222, and arsenic (As) relative to those of other wells, reducing redox conditions, enriched delta sulfur-34 $\left(\delta^{34} \mathrm{~S}\right)$ and delta carbon-13 $\left(\delta^{13} \mathrm{C}\right)$ values, depleted delta oxygen-18 $\left(\delta^{18} \mathrm{O}\right)$ and delta deuterium $(\delta \mathrm{D})$ values, calcite near saturation, low recharge temperatures, and groundwater ages of more than about 9 years; (2) natural organic matter, either in sediments or in an upgradient riparian zone, characterized by high concentrations of DOC or manganese $(\mathrm{Mn})$, low concentrations of dissolved oxygen (DO) and nitrate $\left(\mathrm{NO}_{3}^{-}\right)$, enriched $\delta^{34} \mathrm{~S}$ values, and depleted $\delta^{18} \mathrm{O}$ and $\delta \mathrm{D}$ values; (3) road salt (halite), characterized by high concentrations of sodium (Na), chloride $\left(\mathrm{Cl}^{-}\right)$, and calcium $(\mathrm{Ca})$, and indicative chloride/bromide $(\mathrm{Cl}: \mathrm{Br})$ mass concentration ratios; (4) septic-system leachate, characterized by high concentrations of $\mathrm{NO}_{3}^{-}, \mathrm{DOC}, \mathrm{Na}$,
$\mathrm{Cl}^{-}, \mathrm{Ca}$, and boron (B), delta nitrogen-15 $\left(\delta^{15} \mathrm{~N}\right)$ and $\delta^{18} \mathrm{O}$ values, and indicative $\mathrm{Cl}: \mathrm{Br}$ ratios; (5) organic solvent spills, characterized by detections of perchloroethene (PCE), trichloroethene (TCE), and 1,1-dichloroethene (1,1-DCE); (6) gasoline station spills, characterized by detections of fuel oxygenates and occasionally benzene; and (7) surfacewater leakage, characterized by enriched $\delta^{18} \mathrm{O}$ and $\delta \mathrm{D}$ values and sometimes high DOC and Mn-reducing conditions. Evaluation of $\mathrm{Cl}^{-}$concentrations and $\mathrm{Cl}: \mathrm{Br}$ ratios indicates that most samples were composed of mixtures of groundwater and some component of road salt or septic-system leachate. Leachate from septic-tank drainfields can cause locally anoxic conditions with $\mathrm{NO}_{3}{ }^{-}$concentrations of as much as 19 milligrams per liter ( $\mathrm{mg} / \mathrm{L}$ as $\mathrm{N}$ ) and may provide up to 15 percent of the nitrogen in water from well PSW-1, based on mixing calculations with $\delta^{15} \mathrm{~N}$ of $\mathrm{NO}_{3}^{-}$.

Most of the water that contributes to PSW-1 is young (less than 7 years) and derived from the glacial stratified deposits. Typically, groundwater is oxic, but localized reducing zones that result from abundances of organic matter can affect the mobilization of trace elements and the degradation of VOCs. Groundwater from fractured bedrock beneath the valley bottom, which is old (more than 50 years), and reflects a Mn-reducing to methanic redox environment, constitutes as much as 6 percent of water samples collected from monitoring wells screened at the bottom of the glacial aquifer. Dissolved As and U concentrations generally are near the minimum reporting level (MRL) (0.2 micrograms per liter or $\mu \mathrm{g} / \mathrm{L}$ and $0.04 \mu \mathrm{g} / \mathrm{L}$, respectively), but water from a few wells screened in glacial deposits, likely derived from underlying organic-rich Mesozoic rocks, contain As concentrations up to $7 \mu \mathrm{g} / \mathrm{L}$. At one location, concentrations of As and $U$ were high in sediment sample extractions, and the concentration of dissolved As also was above background levels in the water sample from the well. The relatively low concentrations of $\mathrm{U}$ in water samples from this well are consistent with the low mobility of $\mathrm{U}$ under iron- $(\mathrm{Fe})$ or Mn-reducing conditions. Experimental data for adsorption batch reactor experiments were modeled using PHREEQC with the generalized two-layer surface complexation model 
to determine adsorption reactions. A substantial amount of As and $\mathrm{U}$ was adsorbed onto four different glacial stratified deposit samples, whereas much less was adsorbed onto the sample of glacial till. In fact, there was a net release of U(VI) to solution by the glacial till, which may result from uranylcarbonate complexes that inhibit $\mathrm{U}$ adsorption, although it is possible that there was some $\mathrm{U}(\mathrm{VI})$ co-precipitated with carbonate minerals in the sediment that was released during the adsorption experiment. The net release of U(VI) from glacial till sediments experiments is consistent with higher concentrations of $U$ in water samples from wells screened in deep glacial deposits and in bedrock than those screened in shallow, carbonate-poor glacial deposits. Radon-222 ( $\left.{ }^{222} \mathrm{Rn}\right)$ activities in groundwater samples from the Woodbury study area ranged from 490 to 13,000 picocuries per liter $(\mathrm{pCi} / \mathrm{L})$, and all exceeded the proposed maximum contaminant level (MCL) of $300 \mathrm{pCi} / \mathrm{L}$. The median ${ }^{222} \mathrm{Rn}$ activity of $1,100 \mathrm{pCi} / \mathrm{L}$ for glacial wells was greater than the median of $440 \mathrm{pCi} / \mathrm{L}$ for glacial aquifers of the northeastern United States, and appears to result from an abundant but relatively immobile mass of $U$ and radium-226 $\left({ }^{226} \mathrm{Ra}\right)$ on aquifer sediment surfaces.

Groundwater age plotted as a function of the number of VOC detections indicates that VOC occurrences are related to short groundwater traveltimes, and therefore, young groundwater is more vulnerable to contamination than older groundwater. VOCs were detected at 32 of the 36 wells sampled for this study. Locally high concentrations of gasoline oxygenates (methyl-tert-butyl ether, or MTBE) and chlorinated solvents (PCE, TCE, and 1,1,1-trichloroethane or TCA), and low concentrations of disinfection byproducts were detected in groundwater samples from several wells. Eleven VOCs were detected in untreated water from PSW-1-PCE, TCA, TCE, 1,1-dichloroethane (DCA), cis-1,2-dichloroethene (cis-1,2-DCE), 1,1-dichloroethene (1,1-DCE), MTBE, tert-amyl methyl ether (TAME), ethyl-tert-butyl ether (ETBE), 1,1,2-trichlorotrifluoroethane (CFC-113), and chloroform. Concentrations of TCE in untreated groundwater sampled from PSW-1 frequently exceeded the maximum contaminant level of $5 \mu \mathrm{g} / \mathrm{L}$. Most VOCs were detected in water sampled from shallow or intermediate depths of the glacial aquifer and were associated with commercial- and light-industrial development. MTBE was detected in 50 percent of the wells and was the most frequently detected compound. Chloroform was found in 49 percent of wells and was the second most frequently detected compound, but concentrations in samples from all but two of the wells sites were less than the MRL. The sources of chloroform were attributed to the use of chlorinated drinking water and the associated recharge from septictank drainfields or lawn irrigation, or for well disinfection. Chlorinated solvents were the third most frequently detected group of compounds; two of them-TCE and PCE-exceeded health-based screening concentrations. PCE was detected in 42 percent of wells, and concentrations were highest (up to $11 \mu \mathrm{g} / \mathrm{L}$ ) in samples from several wells downgradient from the commercial development. TCE was found in 33 percent of wells, at concentrations as high as $25 \mu \mathrm{g} / \mathrm{L}$. Pesticides were detected at low concentrations in few wells and this reflects the small amount of agricultural land use in the study area. Atrazine, prometon, simazine, and fipronil were detected at concentrations near or less than the MRL in monitoring wells downgradient from urban areas.

\section{Introduction}

The presence of contaminants and other constituents of concern in aquifers throughout the United States has prompted recent interest in the study of public-supply well vulnerability (Reilly and Pollock, 1993; Kauffman and others, 2001). Anthropogenic contaminants, such as solvents and other VOCs (Zogorski and others, 2006), pesticides (Gilliom and others, 2006), and $\mathrm{NO}_{3}^{-}$(Nolan and others, 1998) have been detected at low concentrations in water from public-supply wells across the United States. In addition, recent studies have found that elevated concentrations (above background) of naturally occurring contaminants, such as $\mathrm{U}$ and As, also are present in wells that supply drinking water (Focazio and others, 1999; Welch and others, 2000; Brown and others, 2007; Ayotte and others, 2007).

The glacial aquifer system is the largest principal aquifer in the United States, by areal extent and withdrawals for public supply (Warner and Arnold, 2006). The vulnerability of public-supply wells generally is high in these areas because of the typically young age of water and the high permeability of the glacial deposits. Urban areas that overlie valley-fill glacial aquifers in the northeast encompass anthropogenic sources or activities that may contribute potential sources of contaminants, such as underground storage tanks, septictank drainfields, chemical spills, application of road salt, stormwater-retention ponds, and fertilizers applied to lawns and golf courses. Furthermore, geochemical conditions may facilitate the mobilization and transport of natural contaminants or constituents of concern in the subsurface that can affect water supplies in some aquifer settings. Protection of groundwater used for public supply requires monitoring and an understanding of the chemical and hydraulic mechanisms that affect groundwater quality.

In 2001, the U.S. Geological Survey (USGS) National Water Quality Assessment (NAWQA) Program began a second cycle of water-quality investigations with in-depth analyses of processes, which are needed to improve the understanding of the mechanisms for distribution and mobilization of contaminants and their transport to publicsupply wells in representative aquifers and geographic areas. To better understand the factors that control the vulnerability of public-supply wells to anthropogenic and natural contaminants, a study of the Transport of Anthropogenic and Natural Contaminants (TANC) to public-supply wells was begun in 2001 (Eberts and others, 2005), using consistent and systematic data collected in a variety of principal aquifer settings in the United States. Seven regional studies were 
conducted in a range of settings using regional groundwaterflow models and water-quality data from public-supply wells (Paschke and others, 2007). More detailed, local-scale (less than $100 \mathrm{~km}^{2}$ ) studies then were conducted in four of these areas, including the Pomperaug glacial aquifer in Woodbury, Connecticut, (the focus of this report) in the Connecticut, Housatonic, and Thames River Basins (CONN). Other studies were conducted in the Upper Floridan aquifer in Tampa, Florida, the High Plains aquifer in York, Nebraska, and the Central Valley aquifer in the eastern San Joaquin Valley near Modesto, California. Contributing-area flow paths were selected to cross a gradient of land uses and terminate at a public-supply well. The flow paths typify the hydrogeology, water chemistry, and sources of contaminants for the respective water-supply aquifer. Flow paths vary in length from about 5 to $8 \mathrm{~km}$. A companion report describes the calibrated groundwater-flow model used to simulate the flow of water to the public-supply well in the delineated groundwater contributing area (Starn and Brown, 2007). Together, the reports serve as a foundation for comparing results among the Woodbury study area and other NAWQA TANC local-scale study areas.

\section{Purpose and Scope}

The purpose of this report is to describe the factors that affect the vulnerability of a public-supply well (PSW-1) to contamination in a glacial aquifer system in Woodbury, Connecticut. The report presents information on the hydrogeologic setting, aquifer geochemistry, and the occurrence and distribution of chemical constituents and characteristics and groundwater ages in the zone of contribution to the public-supply well (PSW-1). A description of the design of the local monitoring well network and methods of data collection and analysis are included. This report describes general water-chemistry characteristics, such as oxidation-reduction (redox) conditions, $\mathrm{pH}$, and water types, in 35 monitoring wells and PSW-1. The interpretative steps for estimating groundwater ages using atmospheric tracers are described, along with the distribution of the interpreted groundwater ages. The occurrence and distribution of selected inorganic and organic chemical constituents are described to help assess groundwater recharge and discharge patterns and pathways, and the occurrence and distribution of contaminant point sources. The transport of anthropogenic contaminants and naturally occurring constituents of concern to supply wells in the TANC study are assessed. Concentrations of natural and anthropogenic and natural constituents are compared to U.S. Environmental Protection Agency (USEPA) Maximum Contaminant Levels (MCLs) to evaluate the potential relevance of the findings to human health.

\section{Description of Study Area}

The TANC study area in Connecticut is within the CONN Study Unit of NAWQA (fig. 1) and on the eastern side of the NAWQA Glacial Aquifers Principal Aquifer area (Warner and Arnold, 2006). The Pomperaug aquifer system underlies the $145-\mathrm{km}^{2}$ watershed drained by the Pomperaug River, its major tributaries - the Nonewaug and Weekeepeemee Rivers - and several smaller streams (Starn and Brown, 2007). Landsurface altitudes range from about $70 \mathrm{~m}$ at the flood plain of the Pomperaug River to about $215 \mathrm{~m}$ in the eastern uplands (in this report, altitudes are referenced to the North American Vertical Datum of 1988). The local-scale study area (herein described as "study area") is a modeled part of the Pomperaug aquifer system that includes the zone of contribution to one public-supply well, PSW-1 (figs. 2 and 3). Advective particle tracking was used by Starn and Brown (2007) to estimate the contributing recharge area to PSW-1 (fig. 2), although uncertainty analysis showed that some recharge outside the designated source area could contribute to PSW-1.

The population of Woodbury increased 2.5-fold from 1950 to 2000; the population in 2000 was 9,198 , or about one person per hectare (U.S. Census Bureau, 2000). From 1985 to 2002,8 percent of the contributing recharge area to PSW-1 changed from agricultural and undeveloped land to developed land (fig. 4A; Starn and Brown, 2007). Agricultural lands, which generally are represented by "agriculture and grasses" in figure 4A, make up only a small percentage of the study area and are located mostly in the uplands. Outside of the study area, agricultural products in the valley bottom include some silage corn, hay, and ornamental plants. Industrial land is limited in extent and includes small, high-tech industries. Upland areas are largely forested with scattered residences on 0.4 hectare or larger lots. Residential and commercial development has been, and still is, greater in the valleys than the uplands and tends to overlie the glacial aquifer; however, the percentage of residential development in the uplands continues to increase.

Most water used for public supply is pumped from wells completed in valley-fill glacial deposits, including PSW-1, although four condominium complexes obtain water from wells completed in bedrock. Numerous residents, mostly in the uplands, obtain water from private wells for domestic use, including lawn irrigation. All residences and businesses are unsewered and generally rely on septic-tank drainfields to dispose of human waste. The term "septic-tank drainfields" is used in this report to describe a septic tank that collects the solids, with a pipe overflow that leads to a series of drain pipes called a leachfield. The septic-tank drainfield density for the 59.9 hectare (ha) contributing recharge area, as estimated from the approximately 42 septic systems in 2005 (Starn and Brown, 2007), was 0.7 sites per ha (70 sites per $\left.\mathrm{km}^{2}\right)$. The population in the contributing recharge area to PSW-1 remained low until about 1950, when the rate of growth increased. Based on land records in the Town of Woodbury, and assuming that each house has a septic-tank drainfield, the 


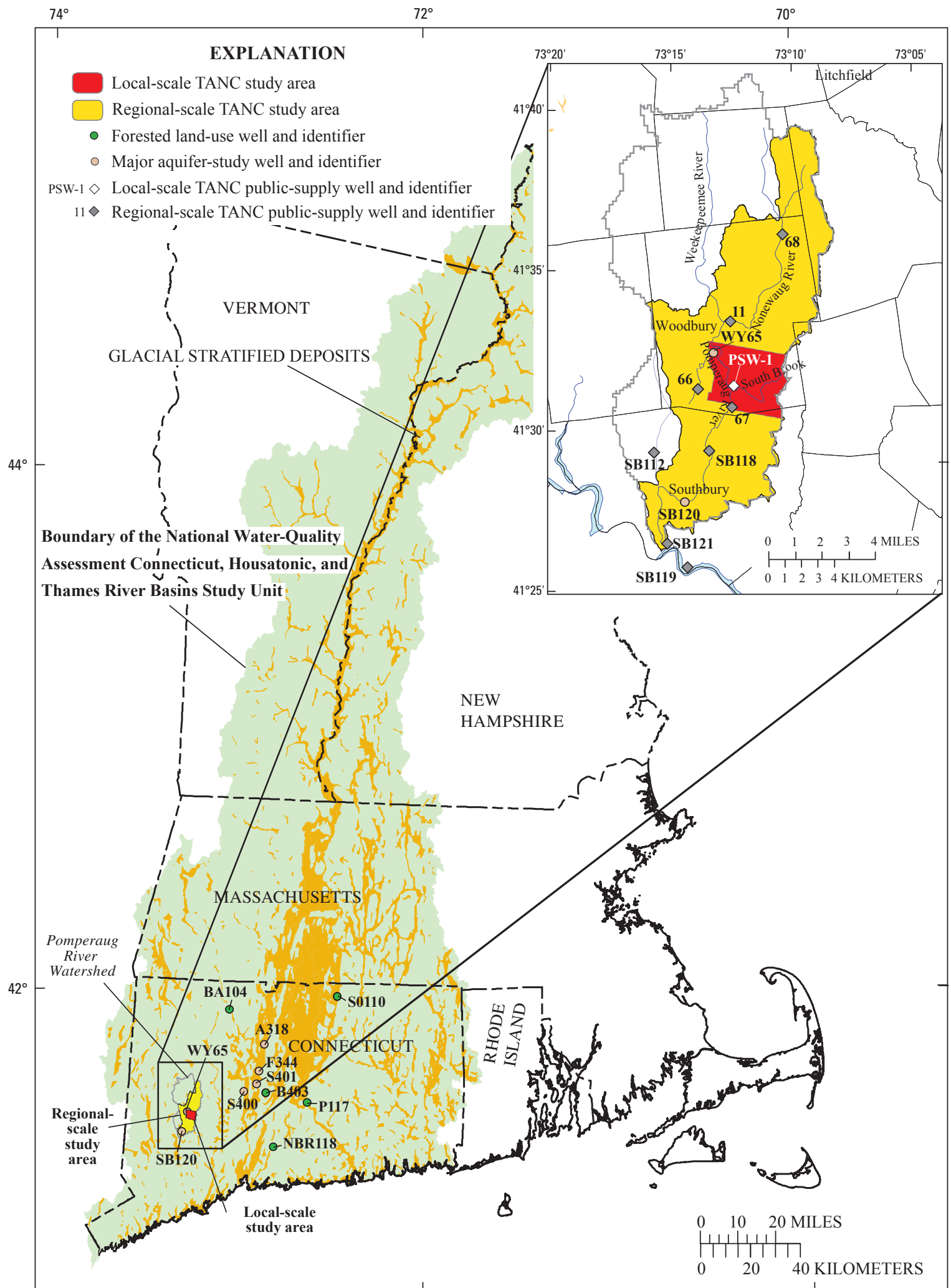

Base from U. S. Geological Survey, 1:24,000, 1969 to 1984 , Projection: Connecticut State Plane Feet

Figure 1. Locations of the regional- and local-scale areas for the study of the Transport of Anthropogenic and Natural Contaminants (TANC) to public-supply wells, monitoring and supply wells used for this study in Connecticut, and the glacial stratified deposits in the Connecticut, Housatonic, and Thames River Basins (CONN) study unit and surrounding area. 


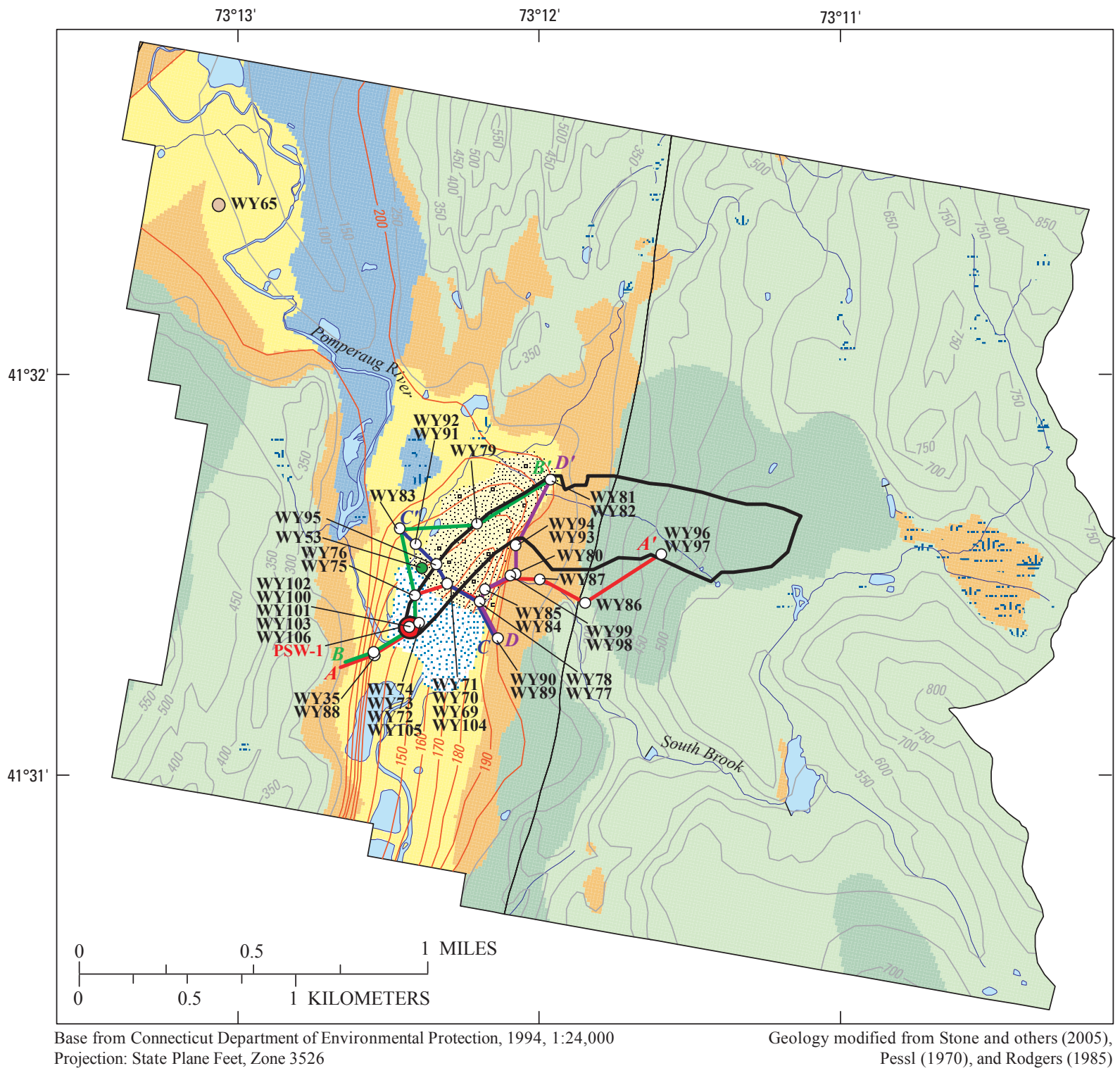

\section{EXPLANATION}

Geohydrologic units

Lake-bottom deposits

Deltaic deposits

Deltaic over fluvial deposits

Fluvial deposits

Fluvial deposits over compact till

Noncompact till

Compact till
Altitude, top of bedrock

- 10 - 10-foot contour interval, in feet above the

North American Vertical Datum of 1988

- 50 - 50-foot contour interval, in feet above the

North American Vertical Datum of 1988

$A \longrightarrow A^{\prime}$ Lines of geologic section

Model contributing recharge area boundary

Model boundary

WY86 $\bigcirc \quad$ Monitoring well and identifier

PSW-1 $\bigcirc$ Public-supply well and identifier

WY65 0 Major aquifer-study well and identifier (cycle II)

Figure 2. Modeled area showing wells, geologic materials, altitude of top of bedrock, lines of hydrogeologic section, and the contributing recharge area to the public-supply well (PSW-1) in the study area, Woodbury, Connecticut. 

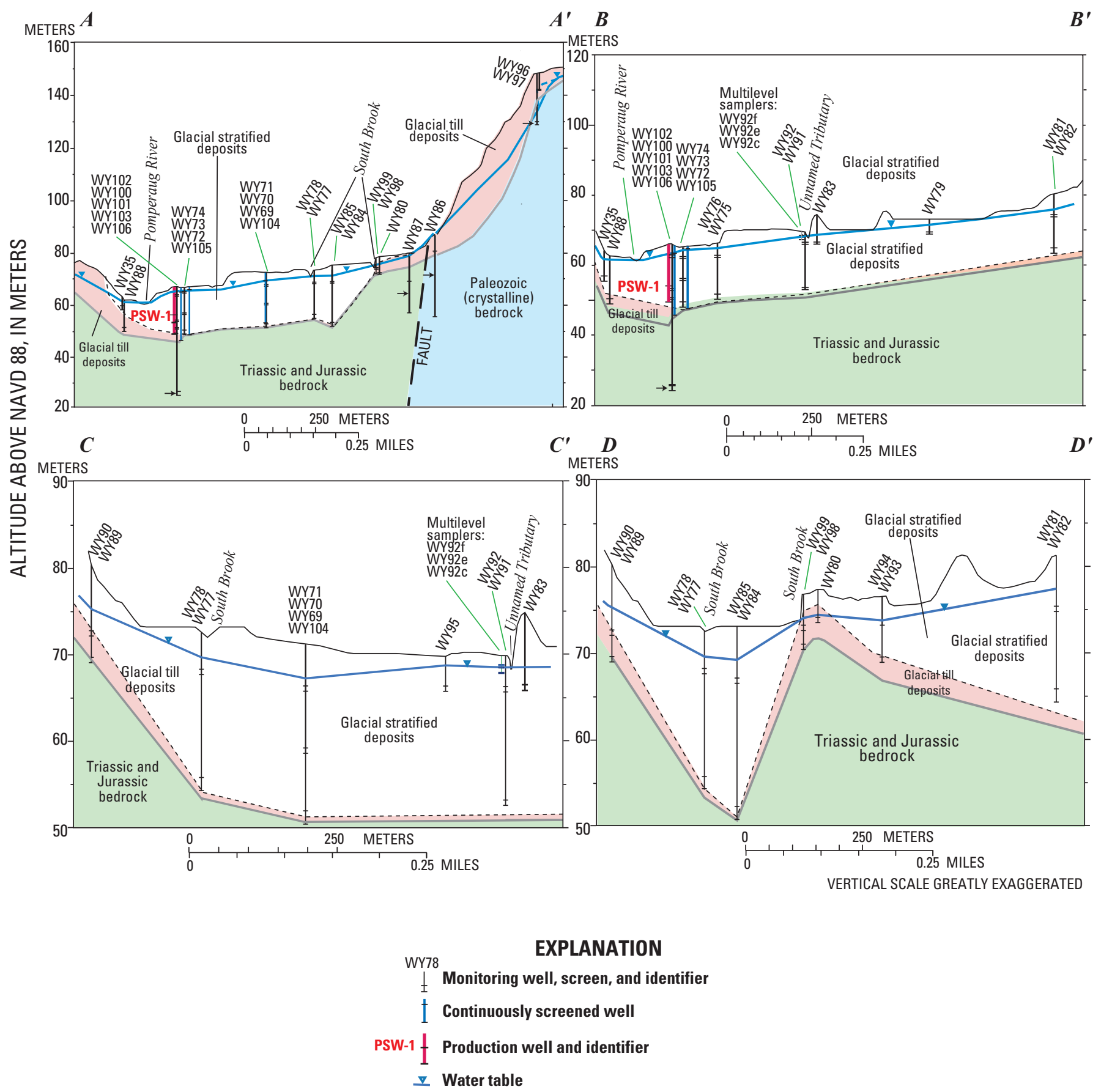

Figure 3. Hydrogeologic sections showing locations and identifiers of wells installed in the study area, Woodbury, Connecticut. 

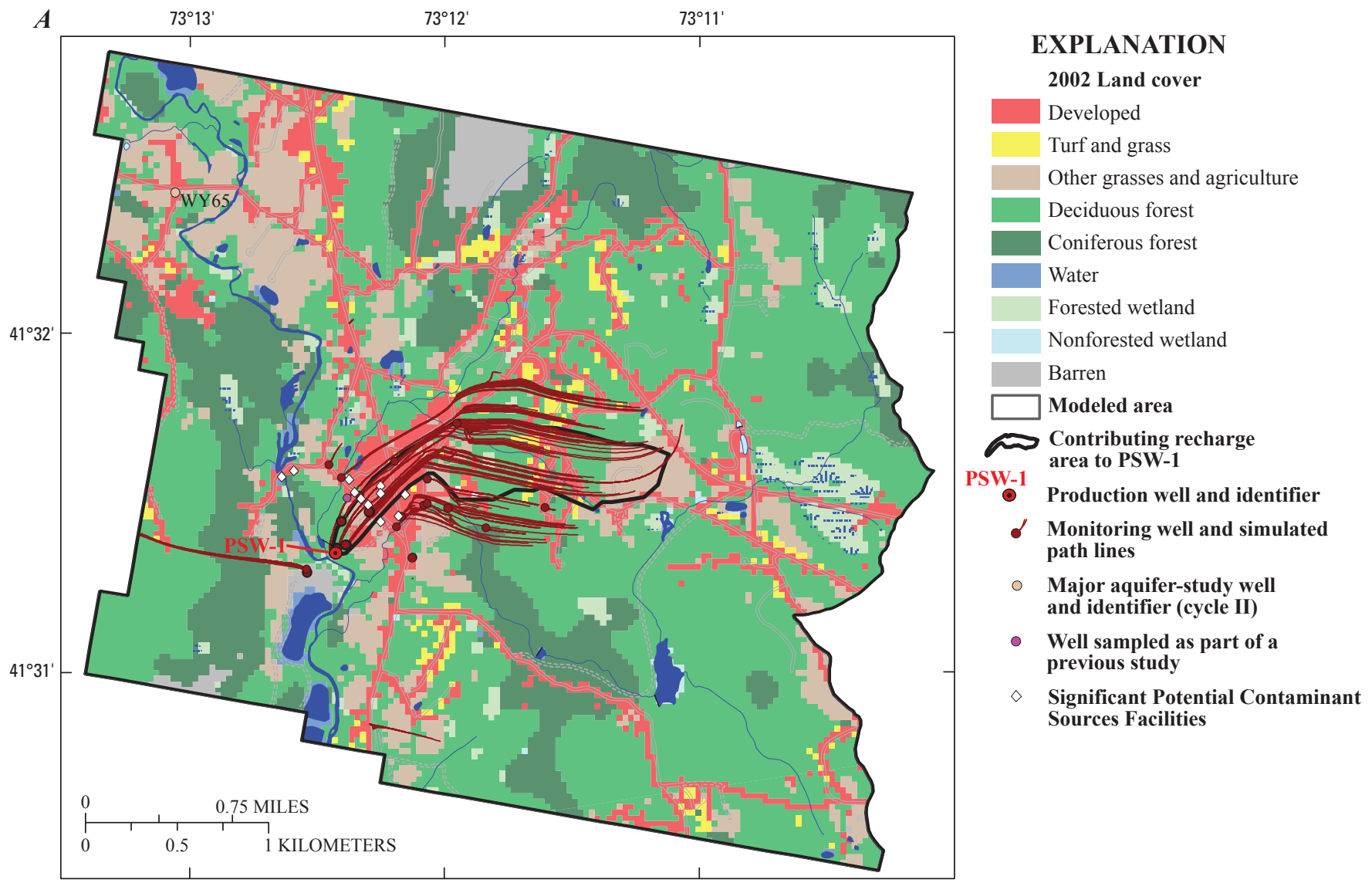

Land cover from Center for Land Use Education and Research, The University of Connecticut, December, 2003

B

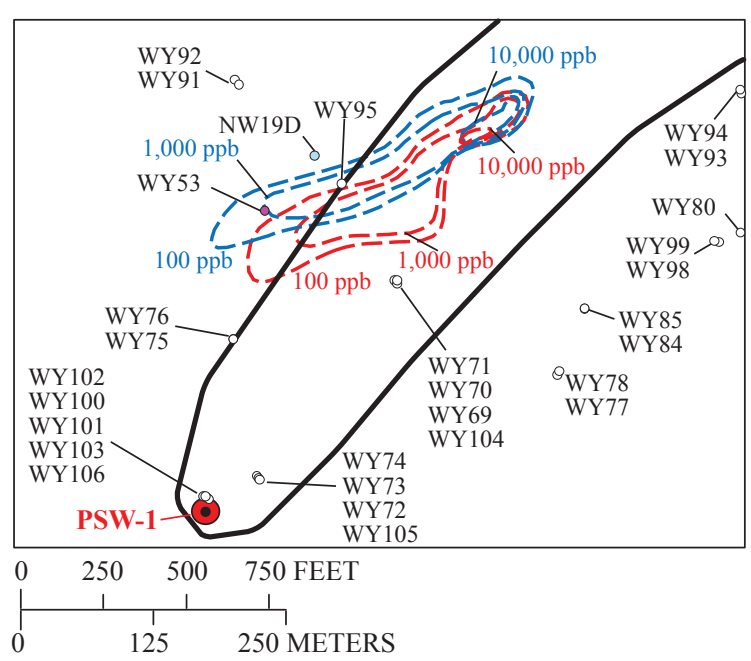

\section{EXPLANATION}

WY95 USGS monitoring well (this study) and identifier

WY53 - USGS monitoring well (previous study) and identifier

NW19D ○ Non-USGS recovery well and well identifier

PSW-1 Production well and identifier

- - - Methyl-tert-butylether (MTBE) concentration contour, depth less than 6 meters

- - - MTBE concentration contour, depth equal to 9 meters

Boundary of contributing recharge area to PSW-1

Figure 4. (A) Land use/land cover for 2002 (Center for Land Use Education And Research, 2003), with Significant Potential Contaminant Sources (SPCSs; Connecticut Department of Public Health, 2007), simulated paths of flow to monitoring wells, and the modeled contributing recharge area to well PSW-1 based on particle tracking with MODPATH (Pollack, 1994), and (B) methyl-tert-butyl ether (MTBE) concentrations, in parts per billion (ppb), in samples collected September 8, 2004, from wells of shallow (less than 6 meters) and intermediate (about 9 meters) depths (Sovereign Consulting, Inc., 2004a), Woodbury, Connecticut. 
Aquifer Chemistry \& Transport Processes in the Zone of Contribution to a Public-Supply Well in Woodbury, CT, 2002-06

number of drainfields in the contributing recharge area follows the general population trend. Water withdrawal records for PSW-1 show a slight increase in summer water use between 1997 and 2001 (Starn and Brown, 2007) and likely is due to a small increase in population.

Several anthropogenic contaminant sources have been identified in the study area, including chlorinated solvent spills or leaks, an MTBE plume emanating from a gasoline station, leakage from septic-tank drainfields, chemical applications to lawns, and deicing salt from road runoff. The MTBE concentrations associated with the gasoline spill were mapped using data from both USGS and non-USGS monitoring wells (fig. 4B; Sovereign Consulting, Inc., 2004a). Chlorinated solvents first observed in samples from PSW-1 in 1978 (Mazzaferro, 1986b) were associated with several light industrial or commercial properties in an area of businesses that is referred to herein as "the commercial area." Facilities that have been identified as Significant Potential Contaminant Sources or SPCSs have been inventoried for the Connecticut Source Water Assessment Program (Connecticut Department of Public Health, 2007) and are abundant in the commercial area (fig. 4A). The SPCSs include sources associated with potentially regulated activities, such as usage and storage of hazardous materials, pesticides, and petroleum products by businesses. These businesses include some manufacturing plants, chemical wholesale storage, gasoline stations, dry cleaners, and furniture strippers. Groundwater from PSW-1 was treated by granular activated carbon (GAC) filtration since the late 1970s, after chlorinated solvents were found in groundwater, then by air stripping beginning in 2003 .

\section{Previous Investigations}

The origin, petrology, and stratigraphy of Mesozoic sedimentary rocks and surrounding Paleozoic rocks within the study area are summarized by Burton and others (2005). Krynine (1950) provides detailed analysis of mineralogy and petrology in a study of the sedimentary rocks of the Hartford and Pomperaug Basins. Hubert and others (1978) and Weddle and Hubert (1983) developed a depositional model, based on petrologic and structural data, that shows the stratigraphic relationships between the Hartford and Pomperaug Basins. The glacial aquifer and overlying Holocene deposits are described in surficial materials maps (Pessl, 1970; Stone and others, 2005). Groundwater conditions in the Pomperaug River watershed have been described in several papers, as summarized in Starn and Brown (2007). Several recent NAWQA studies include wells in the Pomperaug River watershed (CONN-NAWQA website, http://ct.water.usgs.gov/nawqa/index.htm, July 2006). The Groundwater Source Water-Quality Assessment (SWQA) study of 15 public-supply wells in the stratified glacial deposits of Connecticut was conducted to assess the quality of water from community water supplies, including nine wells in the Pomperaug River watershed area (Trombley and others, 2007). A groundwater-flow model was used to delineate the contributing area for these public-supply wells over a large area $\left(128 \mathrm{~km}^{2}\right)$ in the Pomperaug River watershed as part of the regional-scale TANC study (Lyford and others, 2007). As part of the regional study, land use and contaminant point sources were delineated in the contributing areas of each supply well and compared to water-quality data from the public-supply well samples and from other previously obtained samples from other wells in the study area. As part of a NAWQA regional aquifer assessment study (referred to herein as major aquifer study or MAS; Lapham and others, 2005) of the glacial aquifer in the Connecticut, Housatonic, and Thames River Basins study unit, two domestic wells were sampled in the Pomperaug Basin, including a well in Woodbury, in the northern part of the study area, and a well in Southbury, southwest of the study area.

A study of the effects of land use on shallow groundwater quality in the Pomperaug and Pootatuck (located to the south) Basins (Grady and Weaver, 1989) showed that commercial/ industrial areas contained the most degraded groundwater quality. Residential areas had the highest concentrations of most major inorganic constituents and nutrients compared to other land use areas, and some shallow-groundwater samples contained several VOCs, including trichloroethene (TCE), 1,1,1-trichloroethane (TCA), and perchloroethene (PCE), and pesticides, including 2,4-D, 2,4,5-T, and silvex. In agricultural areas, TCE and TCA were detected in groundwater samples, but no pesticides were found. Chloroform was detected widely in source waters from public-supply wells in western and west-central Connecticut and was attributed to a byproduct of disinfection during chlorination (Trombley and others, 2007). Delineation and remediation of a gasoline spill to groundwater beneath the commercial area were conducted in 2004 in response to the presence of several gasoline-related compounds in samples from PSW-1 (Sovereign Consulting, Inc., 2004a and b).

The groundwater chemistry in glacial and alluvial deposits in the New England, New York, and Pennsylvania areas is associated with the chemistry of the underlying bedrock (Rogers, 1989; Grady and Mullaney, 1998; Robinson and Ayotte, 2006). Grady and Mullaney (1998) found substantial differences in the groundwater chemistry of samples from shallow glacial wells in forested, undeveloped areas that overlie four different lithogeochemical types of bedrock in western New England. $\mathrm{SO}_{4}{ }^{2-}$ concentrations, for example, were greater in glacial deposits overlying Mesozoic rocks in the Hartford Basin defined as "arkosic" than in those overlying crystalline, calcareous, or carbonate bedrock. A study of ${ }^{222} \mathrm{Rn}$ in bedrock wells in Connecticut indicated that concentrations are high (from 3,000 to more than $10,000 \mathrm{pCi} / \mathrm{L}$ ) in some of the crystalline rocks in the uplands part of the Pomperaug River watershed (Thomas and others, 1988; Thomas and McHone, 1997). U concentrations can be high in groundwater from bedrock wells in some areas of Connecticut and have been associated with nephrotoxicity in a young child (Magdo and others, 2007). Concentrations 
of As can be high in certain types of fractured bedrock in Connecticut (Brown and Chute, 2002) and may migrate to public-supply wells in adjacent glacial aquifers.

\section{Methods of Data Collection and Analysis}

This section describes the design of the monitoring-well network; the methods of drilling, coring, and installation of monitoring wells; the collection of aquifer material samples for characterizing lithology and mineralogy; the elemental and mineralogic analyses of sediment and rock data; geophysical methods; water-quality sampling and analyses; age dating of groundwater; methods of quality assurance; and data interpretation.

\section{Design of Well Network}

A single public-supply well, PSW-1, was selected for study of the sources and transport of contaminants based on the regional-scale TANC study for the Pomperaug aquifer system (figs. 2 and 3). PSW-1, which supplies water to Woodbury, was constructed in 1967 to a depth of $18.3 \mathrm{~m}$ with 10-in.-diameter steel casing and a 4.6-m-long stainless-steel screen with 0.007-in. slots (table 1; fig. 5) (C.W. Lauman \& Co., written commun., 1967).

The contributing recharge area to PSW-1, estimated using the regional model (Lyford and others, 2007), was used to determine locations for monitoring wells in the local-scale study. Monitoring-well clusters were installed along the most likely flow paths (figs. 2 and 3) determined by a preliminary simulation model. Subsequent uncertainty analysis showed that there was a high probability that the source area to PSW-1 includes an area off the chosen flow path, as discussed in Starn and Brown (2007). Additional wells were drilled to include areas off the flow path, including areas associated with a selected land use or constituent source, to study processes integral to the transport of contaminants that are of (1) local importance to water quality in a typical New England glacialaquifer setting, and (2) regional or national importance. In areas of residential/commercial land use, for example, shallow wells were located near septic-tank drainfields, a losing stream, dry wells, and areas where road deicing is prevalent; these sources or activities are likely to affect groundwater quality locally. Bedrock wells were sampled to determine the contribution of flow and naturally occurring contaminants from upland areas and underlying bedrock.

The monitoring-well network consists of 35 monitoring wells, including 24 screened in glacial stratified deposits, 7 in underlying or adjacent glacial-till deposits, and 4 in underlying or adjacent bedrock (figs. 2 and 3). In most locations, a nest of two to three wells was installed so that different levels within the aquifer could be monitored and sampled. At some locations, wells were drilled into bedrock to characterize the contribution of flow from bedrock to well PSW-1. One previously installed USGS monitoring well, WY35, and PSW-1 were included in the monitoring network (table 1). Other wells in similar hydrogeochemical settings within the study area or in different areas of land use were used in data analysis, including (1) domestic wells in the Pomperaug Basin (WY65 and SB120) and the Hartford Basin (F344 and S401) that were sampled as part of the NAWQA MAS study; (2) a USGS monitoring well, WY53, previously installed in the study area; (3) community supply wells in the Pomperaug Basin (WY11, 66, 67, 68, and SB112, 118, 119 , and 121) that were sampled for the regional-scale TANC study; and (4) NAWQA undeveloped (forested) land-use wells completed in glacial aquifers overlying Mesozoic rocks in the Hartford Basin (SO110, NBR118, P117, and B403; table 1; figs. 1 and 2). Multilevel samplers were installed near a shallow well (WY92) to assess the variation in redox conditions near the water table.

\section{Drilling, Coring, and Well Installation}

Drilling and well installation were completed in three phases. The first set of monitoring wells was installed in the spring, summer, and fall of 2003, the second set was installed in the spring and summer of 2004, and two additional bedrock wells were installed in the winter of 2004. Boreholes were drilled to help define the lithology (and in the case of bedrock wells, geologic structure), to facilitate the collection of solid samples, for the purpose of borehole-geophysical logging at selected sites, and for the installation of monitoring wells. For boreholes in the glacial aquifer, two different methods of drilling were used, including (1) the hollow-stem auger method with split-spoon sampling, and (2) the drive and wash method. Thirty monitoring wells were installed in glacial deposits for this study. Most of the boreholes drilled in the glacial aquifer were installed using the hollow-stem auger method; core samples were obtained from glacial deposits by driving $5.1-\mathrm{cm}$ internal-diameter split spoons at $1.5-\mathrm{m}$ intervals at each well site. The drive and wash method was used at three sites to install continuously screened geophysical monitoring wells that spanned the vertical extent of the glacial aquifer; core samples were not collected during this drilling. Four bedrock wells were drilled, including two cored, open borehole wells (WY86 and WY87) and two boreholes drilled using the air-hammer rotary method and installed with PVC casing and screens (WY97 and WY106). The first two wells were sampled using a wire-line system (NQ) for bedrock coring with a $5.1-\mathrm{cm}(2-\mathrm{in}$.) internal diameter by $1.5-\mathrm{m}(5-\mathrm{ft})$ length split-tube sampler. The second two wells were not cored, but cuttings were collected during the air-hammer rotary drilling.

Core samples of glacial deposits were collected during drilling for visual inspection and later for determination of mineralogy; analysis for trace elements in grain coatings, 


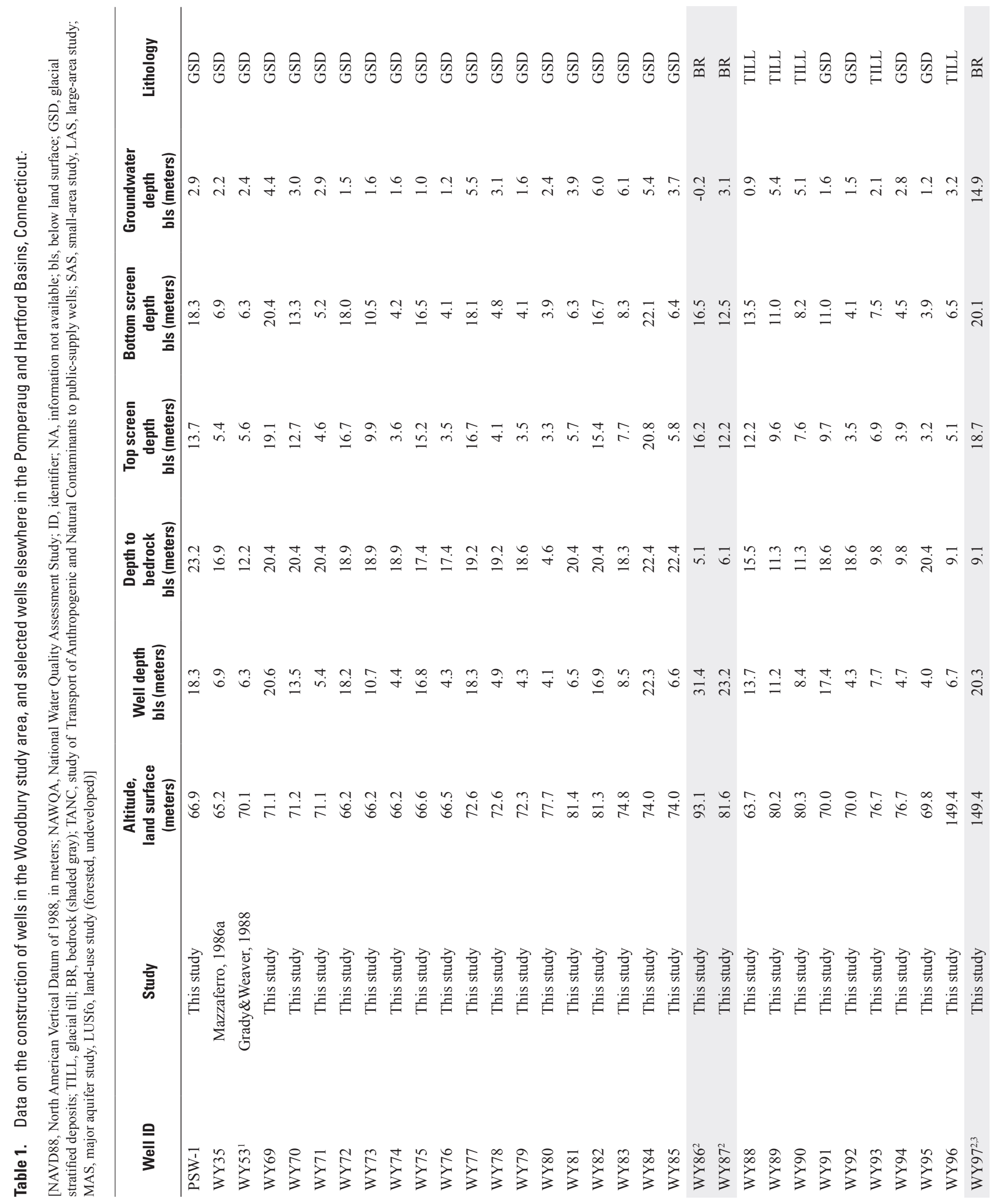




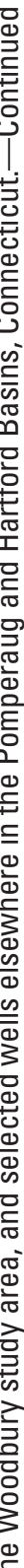

.

का

คิ

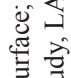

可

을

vis

î

त्ञ

항

.0:

胥 :

:

艺芯

氙

造

ค 莺

总䓀

苞.

范

这

艼艺

융

跑

可

융

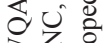

近

的需

कृ

$\exists$ च

은둔

फ

吾袋

킁

㩆

$>$ 䨌

है का

记总

这

乙 के के

- $\quad 00$

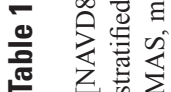

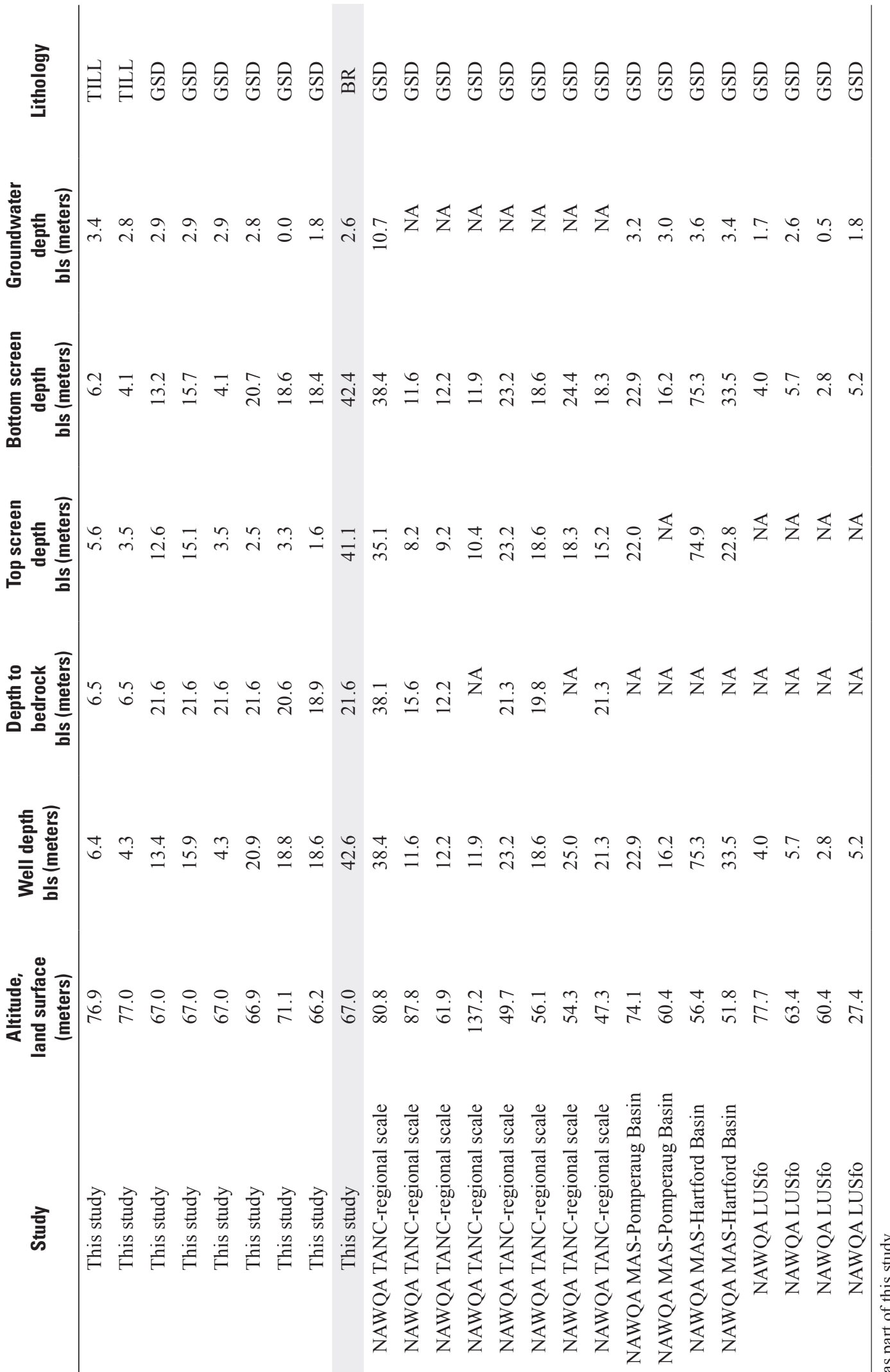

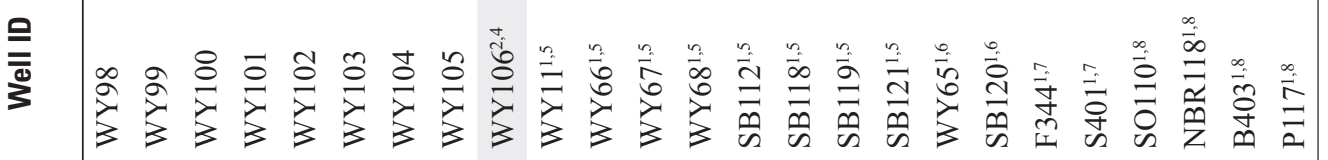

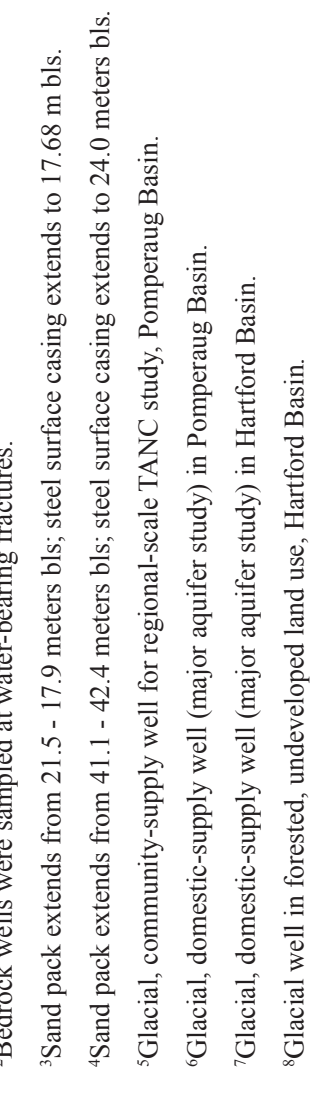




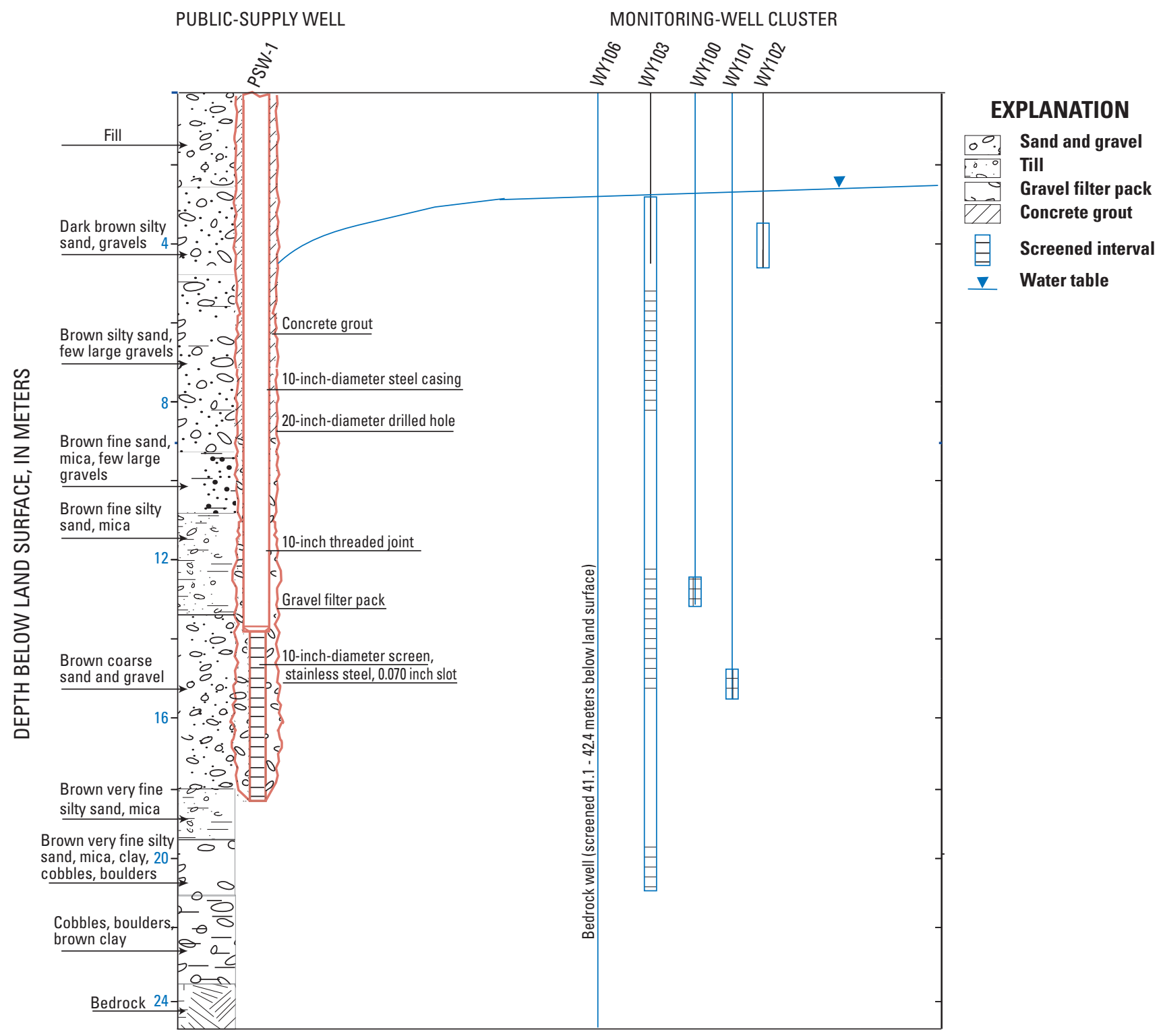

Figure 5. Construction and lithology at public-supply well PSW-1 (C.W. Lauman \& Co., written commun., 1967), and screened intervals for PSW-1 and adjacent monitoring wells WY100, 101, 102, 103, and 106, Woodbury, Connecticut. (Well locations are shown in figure 2).

inorganic and organic $\mathrm{C}$ forms, $\mathrm{N}$, stable isotopes, and sulfides; and determination of bulk density and grain size. Clear, plastic core liners were used in split spoons, and subsamples were cut, then processed (capped and taped) in a glove bag that was continually purged with ultrapure $\mathrm{N}_{2}$. Some subsamples were sealed in Mason jars within the glove bag, then kept on ice. Detailed sediment lithology of these boreholes and the coring procedure for the collection of core samples are described in Appendix 1.

Monitoring wells in the glacial deposits were installed in accordance with NAWQA protocols (Lapham and others, 1995). Five-cm (2-in.) diameter polyvinyl chloride (PVC) casings with 10 -slot $(0.25$-mm slotted) screens were used to construct wells in the glacial deposits (fig. 6). Shallow and intermediate wells generally were constructed with 0.6-m length screens, and deep wells were constructed with 1.3-m length screens. Exceptions include shallow wells in till (WY80, WY89, WY90, WY93, WY96, WY98, and WY99) for which 1.2-m length screens were used. Multilevel samplers, which were installed in the annulus of WY92, consisted of varying lengths of $0.32-\mathrm{cm}(1 / 8$-in.) polyethylene tubing with a 2.5 - to $5-\mathrm{cm}$ ceramic screen at the bottom that was strapped to the well casing (fig. 6). 


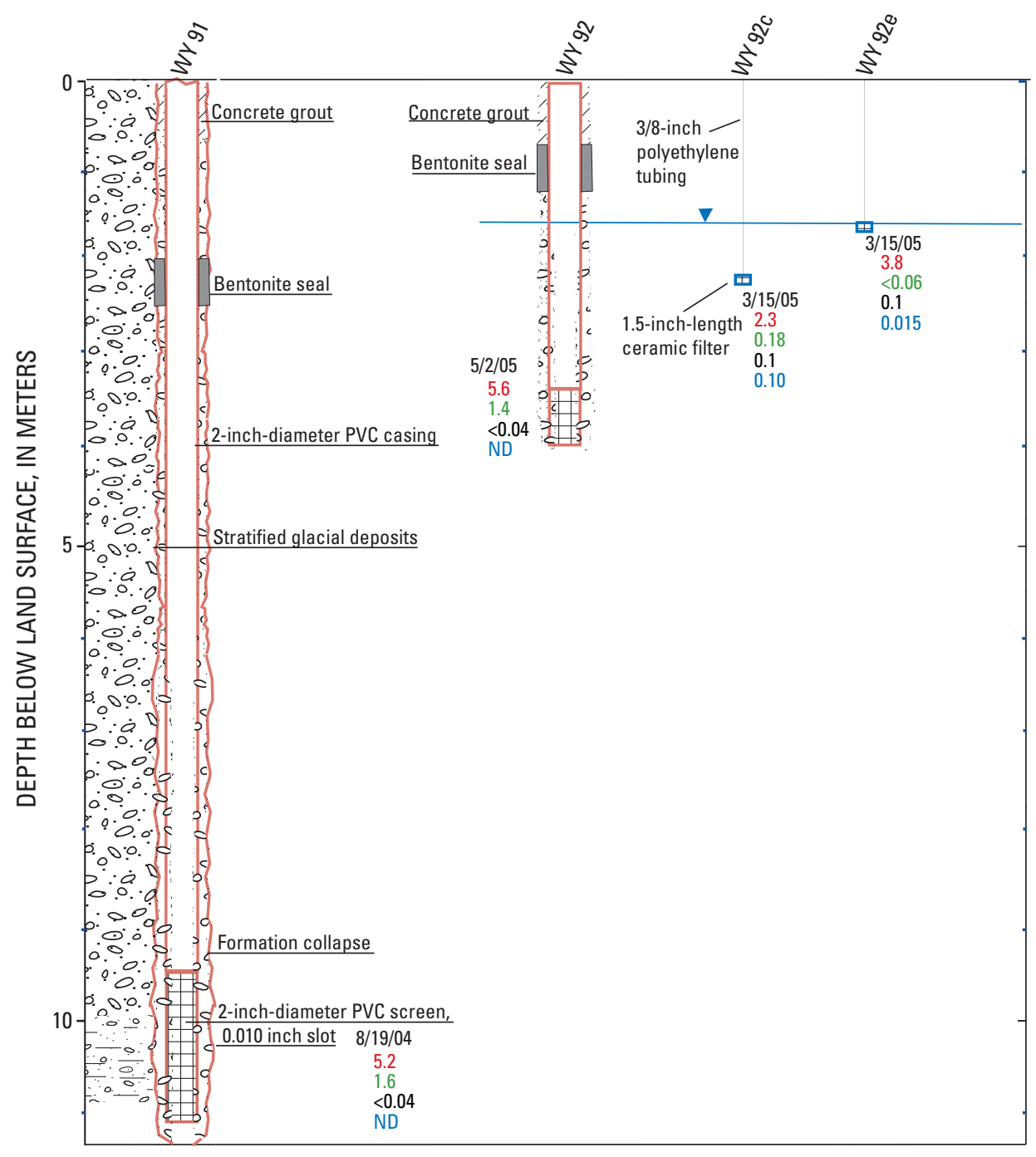

EXPLANATION

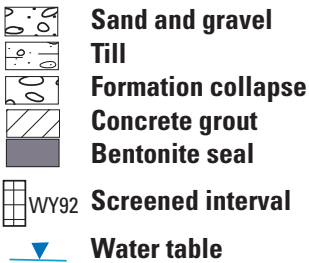

Dissolved constituent concentrations, in milligrams per liter Dissolved oxygen $\mathrm{NO}$ $\mathrm{NH}_{4}^{+}$ $\mathrm{H}_{2} \mathrm{~S}^{4}$ $<$, less than ND, not detected

Figure 6. Construction diagram and lithology at monitoring wells WY91 and 92, and multilevel samplers WY92c and WY92e, Woodbury, Connecticut. (Well locations are shown in figure 2).

Samples were collected from the multilevel samplers using a peristaltic pump.

All four bedrock wells were drilled using mud-rotary and air-rotary percussion drilling with a 0.2 -m-diameter tricone roller drilling bit to penetrate the unconsolidated overburden material and approximately $0.6 \mathrm{~m}$ of competent bedrock. A biodegradable drilling fluid, which is designed to break down after about 48 hours, was used while drilling through the overburden in order to hold the borehole open. For the first and second bedrock wells installed, WY86 and WY87, 10-cm-diameter PVC casing was set into the predrilled boreholes, and a layer of bentonite chips, followed by a mixture of cement and bentonite, was poured into the annular space to seal the casing and isolate the water in the unconsolidated glacial materials from the water in the bedrock. A diamond-impregnated carbide bit was used the following day with a rotary-coring tool to cut into the rock. An NQ wire-line system was used to recover 1.5-m sections of bedrock cores during the drilling process. Bedrock core subsamples were placed in a glove bag that was continually purged with ultrapure $\mathrm{N}_{2}$, then sealed in Mason jars in the glove box and kept on ice.

For the third and fourth bedrock wells, a steel $0.5-\mathrm{m}$ (6-in.) diameter casing was set through the glacial deposits and into the rock. The steel casing, which had a drive shoe affixed to the lower end, was set into the predrilled borehole at wells WY97 and WY106. The casing was hammered into the rock, then grouted with a mixture of cement and bentonite to seal the casing and isolate the water in the unconsolidated glacial materials from the water in the bedrock. A $0.15 \mathrm{~m}$ (6-in.) 
tricone bit then was lowered inside the steel casing, and drilling continued to the predetermined depth. For the third and fourth bedrock wells, the air-rotary method and airhammer rotary method of drilling did not allow for collection of cores, but drill cuttings brought to the surface were collected for visual inspection.

\section{Analysis of Glacial Deposits and Bedrock}

The mineralogy of samples was determined by powder $\mathrm{x}$-ray diffraction (XRD) for both bulk mineralogy and clay separates. Heavy-mineral and magnetic-susceptibility separations were done on sediment samples to identify minerals that could contain sulfides, oxides, and other heavy minerals that might be relevant to aquifer chemistry. The sediment-core subsamples were small $(10 \mathrm{~g})$ and, therefore, may not adequately represent the lithology, but they provided some information that was useful for the assessment of geochemistry and provenance. Once the heavy minerals were sieved to less than 60 mesh, separated using heavy liquids (density greater than $2.7 \mathrm{~g} / \mathrm{cm}^{3}$ ) and magnetic susceptibility, one-half of the sample was ground for emission spectroscopy to provide semiquantitative analysis for 35 elements, and the other half was examined with light microscopy and powder XRD to help identify the minerals. The nonmagnetic fraction, which includes most sulfides, oxides, siderite, and silicates, and the slightly magnetic fraction were analyzed to target the more reactive minerals of interest (Arbogast, 1990).

Fission-track radiography was used on sediment epoxy mounts to determine $\mathrm{U}$ concentrations in aquifer solids. The procedure involves the irradiation of samples with neutrons, which cause fission in ${ }^{235} \mathrm{U}$, for 8 hours with a flux of $2.5 \times 10^{12}$ neutrons per centimeters per second. Some fission fragments recoil from the sample, enter the detector material (muscovite) cover, and create paths of damage that are enlarged by etching with hydrofluoric acid. A higher concentration of $U$ will yield a greater density of tracks and a darker optical image.

Total $\mathrm{C}$ was measured by combustion with an automatic $\mathrm{C}$ analyzer, inorganic $\mathrm{C}$ was determined by coulometric titration of acid-evolved $\mathrm{CO}_{2}$, and organic $\mathrm{C}$ was computed by difference (Arbogast, 1996).

$\mathrm{C}$ and $\mathrm{N}$ in samples of aquifer solids that were collected for isotopic analysis were first converted to $\mathrm{CO}_{2}$ and $\mathrm{N}_{2}$ with an elemental analyzer; these two gases were separated using a gas chromatograph and then analyzed with a continuous-flow isotope-ratio mass spectrometer (Brenna and others, 1997;

Révész and Qi, 2006). Carbonate was reacted with 100 percent $\mathrm{H}_{3} \mathrm{PO}_{4}$ at $25^{\circ} \mathrm{C}$ to liberate $\mathrm{CO}_{2}$, which was collected, purified by vacuum sublimation, and analyzed on an isotope-ratio mass spectrometer (McCrea, 1950). C isotopic ratios are reported in parts per thousand (per mil) relative to the VPDB (Vienna Peedee belemnite) standard by assigning a value of +1.95 per mil to National Bureau of Standard $19 \mathrm{CaCO}_{3}$ (Coplen, 1994). $\mathrm{N}$ isotope ratios are reported relative to $\mathrm{N}_{2}$ in air. Internationally distributed isotope reference materials were interspersed with samples for calibration. The 2-sigma uncertainty of organic $\mathrm{C}$ isotopic results is 0.5 per mil, and that for inorganic $\mathrm{C}$ isotopic ratio results is 0.2 per mil. The 2-sigma uncertainty of $\mathrm{N}$ isotopic ratios is 0.5 per mil. Physical analyses were made of selected core materials including bulk density, percent organic matter (loss on ignition), and volumetric moisture content (R.W. Healy, USGS, written commun., 2005).

The abundances of elements in sediment grain coatings or other mineral phases in samples of aquifer material were evaluated by selective extractions using different acids and reagents, including (1) 10-percent nitric acid $\left(\mathrm{HNO}_{3}\right)$, (2) 6 moles/L (M) hydrochloric acid $(\mathrm{HCl})$ extraction, (3) $0.5-\mathrm{M} \mathrm{HCl}$-hydroxylamine (HA)-extractable $\mathrm{Fe}$, and (4) acid-volatile and Cr-reducible sulfides. All extractions were performed on wet sediments, but the moisture content was determined for a separate subsample and used to correct the analytical concentrations to dry weight. The first two extractions listed were performed in the laboratory environment. For the latter two extractions, core samples were subsampled in a glove bag, and the bottles and flasks were flushed with $\mathrm{N}_{2}$.

The coatings extraction ( $\mathrm{HCl}$ and $\mathrm{HNO}_{3}$ extractions) methods were primarily intended to target ferric oxyhydroxides and their associated trace elements, but they also can extract other oxides and clay, carbonate, and sulfide phases to varying degrees. The sample/solution ratio for the 6-M HCl-HA and 10-percent $\mathrm{HNO}_{3}$ extractions were $5 \mathrm{~g} \pm 1 \mathrm{~g}$ wet weight to $15 \mathrm{~mL}$ (milliliters) of acid solution, whereas that for $0.5-\mathrm{M} \mathrm{HCl}-\mathrm{HA}$ extraction was 4 to $10 \mathrm{~g}$ wet sediment to $75 \mathrm{~mL}$ of reagent. The sediment and acid suspensions were set on a shaker table for 6 hours, then centrifuged, filtered with $0.45-\mu \mathrm{m}$-pore filters, and analyzed for several elements including As and $\mathrm{U}$. Leachate derived from the 10 percent $\mathrm{HNO}_{3}$ extractions was analyzed for $\mathrm{Al}, \mathrm{Cr}, \mathrm{Cu}, \mathrm{Fe}, \mathrm{Mn}$, $\mathrm{Ni}$, and $\mathrm{V}$ by inductively coupled plasma optical emission spectroscopy (ICP-OES). Further dilution to 5 percent was required for analysis of $\mathrm{As}, \mathrm{Cd}, \mathrm{Pb}$, and $\mathrm{U}$ with inductively coupled plasma mass spectrometry (ICP-MS), which yielded lower detection limits. Analysis of the 6-M HCl extractants required further dilution to $1.6-\mathrm{M} \mathrm{HCl}$ prior to analysis by ICP-MS. Leachate derived from the 6-M HCl extractions was diluted to 10 percent and analyzed by ICP-MS for elements that included Fe, $\mathrm{Mn}, \mathrm{Al}, \mathrm{Ca}, \mathrm{Cd}, \mathrm{Cr}, \mathrm{Cu}, \mathrm{K}, \mathrm{Mg}, \mathrm{Na}, \mathrm{Ni}, \mathrm{Pb}$, $\mathrm{V}, \mathrm{Zn}$, and $\mathrm{U}$. The $0.5-\mathrm{M} \mathrm{HCl}-\mathrm{HA}$ and 6-M HCl extractions were performed according to Lovley and Phillips (1987) and analyzed using ICP-MS. The $0.5-\mathrm{M} \mathrm{HCl}-\mathrm{HA}$ extracts were analyzed using the ferrozine method with a spectrometer (HACH Company, 2002).

Sulfide phases in sediments or rock were extracted using a method described by Allen and others (1991; 1993) and summarized in USEPA method 9030B (USEPA, 2006c). However, the method was modified to prevent the oxidization of hydrogen sulfide $\left(\mathrm{H}_{2} \mathrm{~S}\right)$ by soluble ferric Fe by the addition of $\mathrm{SnCl}_{2}$ (M.L. Tuttle, U.S. Geological Survey, oral commun., 
2003 ) and further modified by the addition of $\mathrm{CrCl}_{2}$ (Canfield and others, 1986; Bowles and others, 2003) to also extract pyrite-bound sulfide (K.M. Conko, U.S. Geological Survey, written commun., 2003). Sulfide phases that are extracted using this method include pyrite, elemental $\mathrm{S}$, and acid volatile monosulfides. Samples of 5 to $20 \mathrm{~g}$ of undried sediment were transferred to a $250-\mathrm{mL}$ round-bottomed flask (under $\mathrm{N}_{2}$ ) with $10 \mathrm{~g} \mathrm{SnCl}_{2}$. The flask was attached to an $\mathrm{N}_{2}$ stream on a heating mantle, and $75 \mathrm{~mL}$ of deaerated $6-\mathrm{M} \mathrm{HCl}$ and $50 \mathrm{~mL}$ of $\mathrm{CrCl}_{2}$ solution were added. The samples were heated and kept at a subboiling temperature for $1 \mathrm{hr}$. $\mathrm{H}_{2} \mathrm{~S}$ was collected in two sequential aliquots of $100 \mathrm{~mL}$ of $0.5-\mathrm{M} \mathrm{NaOH}$. Sulfide was analyzed colorimetrically using the methylene blue method (HACH Company, 2002). N concentrations and $\delta^{15} \mathrm{~N}$ values were calibrated against reference materials USGS40 and USGS41 $\left(\delta^{15} \mathrm{~N}=-4.5\right.$ per mil and +47.6 per mil, respectively). The estimated reproducibility of normalized $\delta^{15} \mathrm{~N}$ values is about \pm 0.5 per mil ( 2 sigma). Batch reactor experiments were used to quantify adsorption of $\mathrm{As}(\mathrm{V})$ and $\mathrm{U}(\mathrm{VI})$ using five sediment samples from the study area. Core samples from WY83, WY92, WY94, and WY100 were collected from glacial stratified deposits, and a core sample from WY90 was collected from glacial till. Experiments were conducted by combining $35 \mathrm{~mL}$ of deionized water with $2 \mathrm{~g}$ of sediment in $40-\mathrm{mL}$ polypropylene centrifuge tubes. Adsorption isotherms for $\mathrm{As}(\mathrm{V})$ were determined by diluting $\mathrm{As}(\mathrm{V})$ stock solutions, prepared from $\mathrm{Na}_{2} \mathrm{HAsO}_{4} \times 7 \mathrm{H}_{2} \mathrm{O}$, to obtain initial concentrations ranging from 0 to $500 \mu \mathrm{g} / \mathrm{L}$. Adsorption isotherms for $\mathrm{U}(\mathrm{VI})$ were determined by diluting $\mathrm{U}(\mathrm{VI})$ stock solutions, prepared from $\mathrm{UO}_{3}$, to obtain initial concentrations ranging from 0 to $600 \mu \mathrm{g} / \mathrm{L}$. Sodium bicarbonate was added to each set of samples to approximate the $\mathrm{HCO}_{3}^{-}$concentrations in groundwater associated with each core sample (table 6A). Initial $\mathrm{pH}$ values were adjusted with $0.1-\mathrm{Normal}(\mathrm{N}) \mathrm{H}_{2} \mathrm{SO}_{4}$ to the approximate $\mathrm{pH}$ of groundwater.

The suspensions were mixed continuously on an endrotating mixer at two revolutions per minute (rpm) for five days. It was determined in preliminary experiments that $\mathrm{As}(\mathrm{V})$ and $\mathrm{U}(\mathrm{VI})$ adsorption was rapid, with 90 percent occurring within a few hours and reaching equilibrium within 2 days. Solutions were separated from the sediment by centrifuging at $15,000 \mathrm{rpm}$ for $15 \mathrm{~min}$ and filtering with $0.2-\mu \mathrm{m}$ pore filters. The $\mathrm{pH}$ then was measured, and the $\mathrm{HCO}_{3}{ }^{-}$concentration was determined by titration with $0.2-\mathrm{N} \mathrm{H}_{2} \mathrm{SO}_{4}$ to an end point at $\mathrm{pH}$ 4.5. Both $\mathrm{As}(\mathrm{V})$ and $\mathrm{U}(\mathrm{VI})$ were determined by ICP-MS.

The concentration of surface sites (surf_OH) available for adsorption was estimated for each sediment sample by titration with hydrogen ions. Ten grams of sediment were added to $100 \mathrm{~mL}$ deionized water in a $125-\mathrm{mL}$ Erlenmeyer flask, and the suspension was stirred continuously during the experiments. The initial $\mathrm{pH}$ was increased to 10.12 with $0.1-\mathrm{N} \mathrm{NaOH}$ in order to convert most surface sites to surf_OThe suspensions then were titrated with $0.1-\mathrm{N} \mathrm{HCl}$ to $\mathrm{pH} 3.50$ at which all surface sites were surf_OH ${ }^{2+}$. Because each site consumed two hydrogen ions, the concentration of surface sites was calculated by dividing the moles of acid consumed by two. A deionized-water blank also was titrated to determine the quantity of hydrogen ions that were required to decrease the $\mathrm{pH}$ from 10.12 to 3.50 .

The titration was reversed, from 3.50 to 10.12 , with $0.1-\mathrm{N} \mathrm{NaOH}$ as a check. The number of moles of $\mathrm{OH}^{-}$required to increase $\mathrm{pH}$ from 3.50 to 10.12 was within 95 percent of the moles of $\mathrm{H}^{+}$required to titrate suspensions to $\mathrm{pH} 3.50$ for all samples except those from WY90, which contained a carbonate precipitate that also consumed hydrogen ions. Titration to $\mathrm{pH} 3.50$ dissolved all carbonates, and $\mathrm{N}$-degassing of the solution removed aqueous-carbonate complexes. The $\mathrm{pH} 10.12$ to 3.50 titration was repeated on the carbonate-free sediment to estimate surface-site concentration.

\section{Geophysical Methods}

Both conventional and advanced borehole-geophysical methods were used to provide information on lithology and groundwater flow at three continuous-screen well locations in the glacial aquifer (WY103, WY104, and WY105) and at four borehole locations in the underlying (WY106) and adjacent fractured bedrock (WY86, WY87, and WY97) (Appendix 2; figs. $2-1$ to $2-4$ ). Conventional geophysical-logging methods were used to determine lithologic properties, infer locations where water enters or exits boreholes, and identify variations in dissolved solids in the fluids within a borehole and in the subsurface material adjacent to the borehole. Gamma logging measures the natural-gamma radioactivity of the formation surrounding the borehole; sources include K-40 and daughter products of $\mathrm{U}$ and thorium decay series. Gamma emissions can be correlated with lithology or rock type (clay or micarich material) or with fracture infilling and altered zones in bedrock. Fluid-resistivity logging measures the electrical resistivity of the fluid in the borehole. Changes in the electrical resistivity indicate differences in the concentration of the dissolved solids in the fluid in the borehole. These differences typically indicate sources of water that have contrasting chemistry and have come from different transmissive zones. Caliper logging is used to generate a continuous profile of the borehole diameter with depth and is useful to locate fractures and changes in the lithology or borehole construction.

Advanced borehole geophysical logs were used to identify the lithology of the boreholes and the location, orientation of foliation and laminations in the bedrock, and orientation of fractures intersected by the boreholes. Optical-televiewer (OTV) logging records a continuous, magnetically oriented, digitized 360-degree color image of the bedrock borehole wall (Williams and Johnson, 2000), that can permit the direct inspection of the borehole for fractures, changes in lithology, water level, bottom of casing, and borehole enlargements. The acoustic televiewer (ATV) produces a high-resolution, magnetically oriented, digital image that is used to determine the location and orientation of fractures that intersect the bedrock boreholes (Williams and Johnson, 2000). ATV logging records the amplitude and 
traveltime of the reflected signal, which can be displayed as a flattened 360-degree view of the borehole wall. Planar features such as fractures, foliation, and lithologic contacts can be identified directly on the images as sinusoidal curves that represent planar surfaces. On the acoustic traveltime log, a fracture is indicated by an increase in the one-way traveltime of the wave due to an increase in borehole diameter.

Flowmeter logging was used to measure the direction and rate of vertical flow in boreholes and well screens. A Heat-Pulse Flowmeter (HPFM) was used in the four bedrock boreholes, whereas an electromagnetic (EM) flowmeter was used in the continuous well screens in the glacial aquifer. Fractures (in bedrock) or conductive zones (in sand and gravel) where water enters or exits the borehole or screen can be identified by evaluating the flowmeter results in conjunction with other geophysical logs. Under nonpumping conditions, differences in hydraulic head between two transmissive zones produce vertical flow in the borehole. Flowmeter logging was conducted under nonpumping conditions and under low-rate (1 to $3.8 \mathrm{~L} / \mathrm{min}$ ) pumping conditions to identify transmissive zones with similar heads that could not be identified without stressing the aquifer. For the bedrock wells, measurements were collected at discrete locations, usually above and below fractures, to determine any changes in the vertical flow rate that can be attributed to inflow or outflow at fractures between the measurement sites and to determine locations for screen zones and (or) the acquisition of water samples for waterquality analysis.

\section{Collection and Analysis of Water Samples}

Each well in the sampling network was sampled one to four times during the study, depending on the well depth and the date of installation. Wells along the estimated primary flow path were sampled once for an extensive list of constituents, including major ions and trace elements, ${ }^{222} \mathrm{Rn}$ and radionuclides, dissolved gases, age tracers, stable isotopes, VOCs, and pesticides (table 2). Wells off the primary flow path and shallow source wells, which were installed to characterize contaminant sources, were sampled for a more limited list of constituents (table 2) and were sampled more frequently to assess temporal variability. The shallow monitoring wells and PSW-1, along with the adjacent deep wells, were sampled two or three additional times for a limited list of analytes in order to assess temporal variability. The exception is well WY90, which could not be sampled initially because of the seasonally low position of the water table and the poor yield. A total of 85 samples were analyzed for this study, although some samples were collected from pooryielding wells on more than one occasion because a complete sample set could not be obtained on a given day.

Groundwater was sampled according to protocols by Koterba and others (1995). Wells were purged, and field measurements of temperature, specific conductance, $\mathrm{pH}$, turbidity, and dissolved $\mathrm{O}_{2}$ (DO) concentrations were monitored until stable. Concentrations of total dissolved sulfides ( $\mathrm{H}_{2} \mathrm{~S}$ plus $\mathrm{HS}$, herein referred to as " $\mathrm{H}_{2} \mathrm{~S}$ ") and low concentrations of DO (less than $1 \mathrm{mg} / \mathrm{L}$ ) were measured onsite using colorimetric procedures (HACH Company, 2002). All groundwater samples were analyzed for alkalinity by incremental titration within a few hours after sample collection. Water samples collected for analyses of major ions, trace elements, nutrients, and stable isotopes were filtered with a $0.45-\mu \mathrm{m}$ inline filter; water samples for analysis of pesticides were filtered with a $0.7-\mu \mathrm{m}$ glass-fiber filter. $\mathrm{SO}_{4}{ }^{2-}$ in groundwater was collected on an anion-exchange resin column for sulfur-isotope analysis or water was collected in a bottle if $\mathrm{SO}_{4}{ }^{2-}$ concentrations were sufficiently high (Carmody and others, 1998). Groundwater ages were estimated from concentrations of tritium $\left({ }^{3} \mathrm{H}\right)$, tritium-helium $\left({ }^{3} \mathrm{H}-{ }^{3} \mathrm{He}\right)$ ratios, chlorofluorocarbons (CFCs), and sulfur hexafluoride $\left(\mathrm{SF}_{6}\right)$ tracers. Concentrations of ${ }^{3} \mathrm{H}$ and ${ }^{3} \mathrm{H}-{ }^{3} \mathrm{He}$ ratios were measured in samples from selected wells and converted to residence times for comparison with simulated groundwater residence times (Starn and Brown, 2007). Water samples for $\delta^{13} \mathrm{C}$ analysis of dissolved inorganic carbon (DIC) were collected in 1-L glass bottles, which were filled from the bottom up and sealed with a Teflon/silicon septa cap after a minimum of 3 to $5 \mathrm{~L}$ were allowed to overflow the bottle to eliminate $\mathrm{O}_{2}$.

Groundwater samples to be analyzed for dissolved gases were collected in 160-mL septum bottles (sealed in a large beaker under flow of evacuated well water) and (or) in $\mathrm{Cu}$ tubes with pinchoff valves. In several cases, the samples in the septum bottles also were measured for $\delta^{15} \mathrm{~N}$ of $\mathrm{N}_{2}$. Dissolved gases $\left(\mathrm{N}_{2}, \mathrm{Ar}, \mathrm{CO}_{2}, \mathrm{CH}_{4}, \mathrm{O}_{2}, \mathrm{Ne}\right.$, and $\left.\mathrm{He}\right)$ were analyzed in groundwater samples by gas chromatography after extraction in headspaces of glass sample bottles (Busenberg and others, 1998). The resulting data were used to define recharge temperatures (1) for age dating because the solubility of atmospheric tracers varies as a function of temperature, (2) for determining concentrations of excess air and excess $\mathrm{N}_{2}$ to reconstruct initial $\mathrm{NO}_{3}{ }^{-}$concentrations on the basis of the amount of denitrification that has occurred (Plummer and others, 2003), and (3) for tracing sources of groundwater recharge. Excess air consists of air trapped in pores that dissolves in groundwater, typically after a rapid rise in the water table. The amount of excess $\mathrm{N}_{2}$ reflects the amount of denitrification that has taken place. Recharge temperatures were calculated from $\mathrm{Ne}$ and $\mathrm{Ar}$ gas concentrations where these gases were both analyzed, and from $\mathrm{N}_{2}$ and $\mathrm{Ar}$ gas concentrations in samples where $\mathrm{Ne}$ concentration data were not available. $\mathrm{N}_{2}$ concentrations can be affected by denitrification under denitrifying conditions (where concentrations of $\mathrm{O}_{2}$ are less than $3 \mathrm{mg} / \mathrm{L}$, those of $\mathrm{Fe}$ are greater than $0.3 \mathrm{mg} / \mathrm{L}$, and those of $\mathrm{Mn}$ are greater than $0.1 \mathrm{mg} / \mathrm{L}$, and (or) $\mathrm{HS}^{-}$or $\mathrm{CH}_{4}$ are present) and, therefore, are not as reliable as Ne concentrations, particularly in samples where excess $\mathrm{N}_{2}$ is present. In one sample where gas samples were exsolving (probably due to methanogenesis and (or) generation of $\mathrm{H}_{2} \mathrm{~S}$ ), the He concentration also was used to constrain the recharge temperature. $\mathrm{Ne}$ and $\mathrm{Ar}$ are the more 
Table 2. Classes of water-quality chemical characteristics and constituents measured in water samples from the Woodbury, Connecticut, study area for the flow-path, source-well, and stream-sampling analyte schedules, October 2002 to July 2006.

[Water-quality field parameters: temperature, $\mathrm{pH}$, specific conductance, dissolved oxygen, dissolved sulfides, alkalinity; DOC, dissolved organic carbon; $\mathrm{Ra}$, radium; Rn, radon; He, helium; O, oxygen; $\mathrm{H}$, hydrogen; $\mathrm{N}$, nitrogen; $\mathrm{C}$, carbon; $\delta$, delta; As, arsenic; $\mathrm{SO}_{4}{ }^{2-}$, sulfate; CFCs, chlorofluorocarbons CFC11, CFC12, CFC113; analyses done by the U.S. Geological Survey National Water Quality Laboratory, unless otherwise indicated]

\begin{tabular}{|c|c|c|}
\hline Flow-path schedule & Source-well schedule & Stream-sampling schedule \\
\hline Water-quality field parameters & Water-quality field parameters & $\delta^{18} \mathrm{O}$ and $\delta^{2} \mathrm{H}(\delta \mathrm{D})$ isotopes $^{1}$ \\
\hline Volatile organic compounds (VOCs) & Volatile organic compounds (VOCs) & \\
\hline Pesticides and herbicide metabolites & DOC and ultraviolet absorbance & \\
\hline Major inorganic constituents and nutrients & Stable isotopes (selected sites) & \\
\hline As species, $\mathrm{As}[\mathrm{V}]$ and $\mathrm{As}[\mathrm{III}]$ & ${ }^{222} \mathrm{Rn}$ (selected sites) & \\
\hline DOC and ultra-violet (UV) absorbance & ${ }^{3} \mathrm{H}-{ }^{3} \mathrm{He} \operatorname{ratios}^{2}\left(\delta^{3} \mathrm{He}\right)$ (selected sites) & \\
\hline$\delta^{15} \mathrm{~N}$ isotopes ${ }^{1}$ in dissolved $\mathrm{NH}_{4}^{+}$ & $\mathrm{CFCs}^{3}$ & \\
\hline$\delta^{15} \mathrm{~N}$ and ${ }^{18} \mathrm{O}$ isotopes ${ }^{1}$ in dissolved $\mathrm{NO}_{3}^{-}$ & Sulfur hexafluoride ${ }^{3}\left(\mathrm{SF}_{6}\right)$ (selected sites) & \\
\hline $\mathrm{Ra}$ isotopes ${ }^{5}\left({ }^{226} \mathrm{Ra} \&{ }^{228} \mathrm{Ra}\right)$ & & \\
\hline Gross alpha / gross beta radiation ${ }^{5}$ & & \\
\hline${ }^{222} \mathrm{Rn}$ & & \\
\hline Dissolved gases ${ }^{6}$ & & \\
\hline${ }^{3} \mathrm{H}(\text { tritium })^{7}$ & & \\
\hline${ }^{3} \mathrm{H}-{ }^{3} \mathrm{He} \operatorname{ratios}^{2}\left(\delta^{3} \mathrm{He}\right)$ & & \\
\hline${ }^{4} \mathrm{He}$ isotopes ${ }^{3}$ & & \\
\hline $\mathrm{CFCs}^{3}$ & & \\
\hline
\end{tabular}

${ }^{1}$ Analyzed at the USGS Reston Isotope Laboratory, Virginia.

${ }^{2}$ Analyzed at the Lamont Doherty Earth Observatory, Tritium-Helium Laboratory, New York.

${ }^{3}$ Analyzed at the USGS CFC Laboratory, Virginia.

${ }^{4}$ Analyzed at the University of Waterloo, Ontario.

${ }^{5}$ Analyzed at Eberline Services, Richmond, California.

${ }^{6}$ Analyzed at the USGS Dissolved Gas Laboratory, Virginia.

${ }^{7}$ Analyzed at the University of Miami Laboratory, Florida. 
conservative of the gases analyzed and were the first choice used to calculate recharge temperatures and excess air by using a back-solving routine to iterate between the solubility of each until they converged to a common value. In samples where $\mathrm{Ne}$ was not analyzed, $\mathrm{N}_{2}$ and Ar gases were used in the same way to calculate the recharge temperature. For samples in which excess $\mathrm{N}_{2}$ concentrations were estimated, an uncertainty analysis was done to estimate denitrification. To obtain the upper and lower limits of uncertainty, the excess $\mathrm{N}_{2}$ concentration was varied, first until the average excess air temperature was obtained, then until the average amount of excess air was reached. Dissolved gases were measured by gas chromatography after extraction from headspaces of glass samplers (Busenberg and others, 1998).

Multilevel samplers that were installed with their openings in the saturated zone above the screen at WY92 were pumped with a peristaltic pump for 3 to $5 \mathrm{~min}$ before $\mathrm{pH}$, specific conductance, $\mathrm{DO}$, and $\mathrm{H}_{2} \mathrm{~S}$ were measured; $\mathrm{H}_{2} \mathrm{~S}$ was measured colorimetrically with a spectrometer. Samples were collected for analysis of nutrients at these sites. Because air bubbles were abundant in the water evacuated during sampling, however, concentrations of DO were likely to be artificially high and those of $\mathrm{H}_{2} \mathrm{~S}$, artificially low.

Water samples were analyzed for major and trace constituents, nutrients, DOC, ${ }^{222} \mathrm{Rn}$, pesticides, and VOCs by the USGS National Water-Quality Laboratory (NWQL) in Denver, Colorado. Major ions and trace elements were analyzed by ICP-MS, atomic-absorption spectrometry, or ion chromatography (Fishman and Friedman, 1989; Fishman, 1993; and Faires, 1993). Samples were analyzed for ultraviolet absorbance at 254 nanometers and 280 nanometers. Nutrient concentrations were determined by colorimetry (Fishman, 1993; Patton and Kryskalla, 2003). VOCs samples were unfiltered and determined by gas chromatography and mass spectrometry using methods described in Connor and others (1998). Pesticides samples were filtered and analyzed by solid-phase extraction and capillary column gas chromatography/mass spectrometry (Kish and others, 2000; Zaugg and others, 1995). DOC was analyzed by ultravioletpromoted persulfate oxidation and infrared spectrometry (Brenton and Arnett, 1993). ${ }^{222} \mathrm{Rn}$ was analyzed by liquid scintillation (American Society for Testing and Materials, 1996). Activity of ${ }^{226} \mathrm{Ra}$ was measured by ${ }^{222} \mathrm{Rn}$ emanation, and activity of ${ }^{228} \mathrm{Ra}$ was measured by beta counting, following standard USEPA methods (EPA 903.1; EPA 904.0-modified; Krieger and Whittaker, 1980). Water-quality samples were collected for 72-hour and 30-day gross alpha and gross beta activities and determined at Eberline Services of Richmond, California, by evaporating an aliquot of sample and counting alpha and beta emissions from the residue (EPA 900.0 modified; USEPA, 1980).

Stable isotopes were analyzed using several different methods. Analyses of the stable isotopes of water, deuterium $\left(\delta \mathrm{D}\right.$ or $\left.\delta^{2} \mathrm{H}\right)$ and $\delta^{18} \mathrm{O}$ were done at the USGS Stable Isotope Laboratory in Reston, Virginia; a hydrogen equilibration method was used for $\delta \mathrm{D}$ analysis (Coplen and others,
1991), and the $\mathrm{CO}_{2}$ equilibration technique (Epstein and Mayeda, 1953) was used for analysis of $\delta^{18} \mathrm{O}$. Analytical uncertainties for $\delta \mathrm{D}$ and $\delta^{18} \mathrm{O}$ values are 2 and 0.2 per mil, respectively. Isotopes of $\mathrm{N}$ and $\mathrm{O}$ of $\mathrm{NO}_{3}{ }^{-}$were analyzed using bacterial conversion of $\mathrm{NO}_{3}^{-}$to nitrous oxide, and values were reported relative to $\mathrm{N}_{2}$ in air, and the Vienna Standard Mean Ocean Water (VSMOW), respectively (Sigman and others, 2001; Casciotti and others, 2002; Révész and Casciotti, 2007). $\mathrm{SO}_{4}{ }^{2-}$ in groundwater and $\delta^{34} \mathrm{~S}^{\text {in }} \mathrm{SO}_{4}{ }^{2-}$ were analyzed for $\mathrm{BaSO}_{4}$ precipitates using procedures described in Carmody and others (1998). Results are reported in per mil relative to the Vienna Canyon Diablo Troilite (VCDT) standard. The uncertainty associated with $\delta^{34} \mathrm{~S}$ values is \pm 0.2 per mil. Water samples were analyzed for $\delta^{13} \mathrm{C}$ using mass-spectrometry techniques at the University of Waterloo Environmental Isotope Laboratory in Waterloo, Canada, and are reported relative to the Vienna Pee Dee Belemnite (VPDB) standard. The uncertainty associated with the $\delta^{13} \mathrm{C}$ values is \pm 0.2 per mil.

The age tracers ${ }^{3} \mathrm{H},{ }^{3} \mathrm{H}-{ }^{3} \mathrm{He}$, CFCs (CFC-11, CFC-12, and $\mathrm{CFC}-113$ ), and $\mathrm{SF}_{6}$ were collected and measured to estimate the apparent groundwater age. Anthropogenic activities, such as industrial processes and atmospheric testing of thermonuclear devices, released ${ }^{3} \mathrm{H}, \mathrm{SF}_{6}$, and $\mathrm{CFCs}$ into the atmosphere in small but measurable concentrations. Precipitation that incorporates these gases from the atmosphere infiltrates into the ground and carries the particular chemical or isotopic signature of the atmospheric conditions at the time of recharge. These dating methods assume that gas exchange between the unsaturated zone and the atmosphere is fast, but that shallow groundwater remains closed to gas exchange after recharge (Schlosser and others, 1989; Plummer and Busenberg, 1999; Busenberg and Plummer, 2000). Where possible, two age-dating indicators were used for several wells that are thought to lie along the primary flow path within the modeled contributing area to the supply well. Certain tracer methods were avoided for wells that are known or suspected to have contamination from natural or anthropogenic sources not carried naturally by recharge. Unless otherwise noted, apparent ages were estimated by assuming that piston flow prevails in the aquifer system.

The ${ }^{3} \mathrm{H}-{ }^{3} \mathrm{He}$ samples were collected in (1) special $\mathrm{Cu}$ tubes for ${ }^{4} \mathrm{He}$ and $\mathrm{Ne}$ analyses and determination of $\delta^{3} \mathrm{He}$ in dissolved $\mathrm{He}$, and (2) $500-\mathrm{cm}^{3}$ bottles for ${ }^{3} \mathrm{H}$ determination by He ingrowth (Plummer and others, 1993). The samples for the determination of ${ }^{4} \mathrm{He}, \mathrm{Ne}$, and $\delta^{3} \mathrm{He}$ in dissolved $\mathrm{He}$ were collected in pinched-off copper tubes while back pressure was applied to prevent formation of gas bubbles. These samples were analyzed at the Noble Gas Laboratory of LamontDoherty Earth Observatory in Palisades, New York, by using quantitative gas extraction followed by mass spectrometric techniques (Schlosser and others, 1989).

The ${ }^{3} \mathrm{H}$ in water was measured at the Tritium Laboratory at the University of Miami, by internal gas proportional counting of $\mathrm{H}_{2}$ - gas made from the water samples. ${ }^{3} \mathrm{H}$ that was released into the atmosphere from nuclear weapons 
tests between 1952 and 1963 provides a tracer for rainwater that allows dates of recharge to be estimated. Although ${ }^{3} \mathrm{H}$ concentrations are now (2007) approaching that of natural atmospheric production (15 to $25^{3} \mathrm{H}$ units), they remain high enough to use in this analysis. Bomb-related ${ }^{3} \mathrm{H}$ can be used to infer some aspects of groundwater age; at the very least, water can be recognized as being recharged before or after 1953. Determination of both ${ }^{3} \mathrm{H}$ and tritiogenic ${ }^{3} \mathrm{He}$ in groundwater can define the initial ${ }^{3} \mathrm{H}$ content and allow calculation of the apparent ${ }^{3} \mathrm{H}-{ }^{3} \mathrm{He}$ age. Details of ${ }^{3} \mathrm{H}-{ }^{3} \mathrm{He}$ dating procedures are presented in Schlosser and others (1988) and Solomon and Cook (1999). Analytic uncertainty is approximately \pm 0.5 years. Larger uncertainties in age can result from (1) corrections in defining the tritiogenic ${ }^{3} \mathrm{He},(2)$ the assumption that the parcel of water remains confined following infiltration, and (3) mixing effects caused by hydrodynamic dispersion. Limitations to ${ }^{3} \mathrm{H}-{ }^{3} \mathrm{He}$ dating of groundwater in the study area include the addition of terrigenic $\mathrm{He}$ from crystalline rock sources and loss of ${ }^{3} \mathrm{H}$ by degassing during sampling. For example, samples from wells drilled in the Taine Mountain Formation and a pegmatite (both discussed in section "Hydrogeologic Setting") in the uplands of the study area contain excessive terrigenic $\mathrm{He}$ derived from the crystalline rock sources, which precluded the determination of ages. He excess in samples, in which an old fraction contains mixed mantle and crustal He sources that are as much as 50 percent greater than that of air-water equilibrium $\left(4.6 \times 10^{-8} \mathrm{~cm}^{3} \mathrm{STP} / \mathrm{g}\right)$, can invalidate or create large uncertainties in ${ }^{3} \mathrm{H}-{ }^{3} \mathrm{He}$ dating (Plummer and others, 2003). Wells screened in the glacial deposits also had elevated terrigenic $\mathrm{He}$, but values were corrected; those interpretations are discussed in the section on groundwater age.

The CFC samples were collected by inserting the end of the discharge tubing into the bottom of the bottle, allowing at least $2 \mathrm{~L}$ to overflow into a 2-L beaker, then capping the $125-\mathrm{mL}$ glass bottles with special foil-lined caps under water within the beaker. Groundwater samples for $\mathrm{SF}_{6}$ were collected by placing the sampling discharge line in the bottom of the bottle and displacing the air in the bottle with groundwater. After approximately $2 \mathrm{~L}$ of overflow, the sampling line was removed. The bottles were capped with polyseal conical screw caps without headspace and wrapped with electrical tape to prevent the caps from coming loose during shipping.

Concentrations of trichlorofluoromethane (CFC-11), dichlorodifluoromethane (CFC-12), and CFC-113 in water were determined at the USGS CFC laboratory in Reston, Virginia, with a detection limit of about $0.3 \mathrm{pg} / \mathrm{L}$ using purge and trap, gas-chromatographic techniques with electroncapture detector (GC-ECD) (Bullister, 1984; Bullister and Weiss, 1988; Busenberg and Plummer, 1992). Age dating with CFCs was done for samples from only two of the bedrock wells because of contamination by CFC point sources in groundwater underlying, or downgradient from, commercially developed land. The CFC-dating technique is described in Busenberg and Plummer (1992). Samples were analyzed for $\mathrm{SF}_{6}$ at the USGS CFC laboratory using procedures described by Busenberg and Plummer (2000). Terrigenic sources that are known to occur naturally, produce $\mathrm{SF}_{6}$ at low concentrations in some crystalline rocks (Busenberg and Plummer, 2000), which can result in apparent ages that are too young. Source rocks for naturally occurring $\mathrm{SF}_{6}$ in the study area may include upland igneous and metamorphic rocks, Mesozoic sedimentary rocks (derived from metamorphic rocks) that contain quartz grains with fluid inclusions (Krynine, 1950), and glacial deposits that contain both source rocks.

\section{Statistical Analysis}

Statistical procedures were used to describe distributions of data grouped by the lithologic composition of the aquifer, or to test for differences in the concentration or frequency of detection of water-quality variables for each group. Boxplots (Helsel and Hirsch, 1995) were constructed to show differences between groups of data that are uncensored or slightly censored ( 75 percent or more of the data greater than detection or reporting limits). Boxplots of selected data presented in this report illustrate the 10th, 25th (1st quartile), 50th (median), 75th (3rd quartile), and 90th percentiles of the data distributions, plus values outside of the 10th and 90th percentiles (outliers).

Hypothesis tests were used to test for significant differences in water-quality variables among populations groupings. A one-factor analysis of variance (ANOVA) compares the mean values of each group with the overall mean for the entire data set and was used to test the null hypothesis that the group means, which include those for $\mathrm{pH}$ and $\mathrm{HCO}_{3}^{-}$, are identical to the overall mean (Helsel and Hirsch, 1995). Rejection of the null hypothesis at the $\alpha=0.05$ level of significance was considered evidence supporting the alternative hypothesis that the group means differ from the overall mean. The Kruskal-Wallis rank sum test, which is a nonparametric alternative to the one-way ANOVA (Helsel and Hirsch, 1995), was performed on data with a nonnormal distribution, including those for $\mathrm{DOC}$ and $\mathrm{NO}_{3}^{-}$.

\section{Quality Assurance}

Quality-assurance samples were collected to assess laboratory performance and to help identify contamination problems associated with field-collection methods. Qualityassurance information for this study included the collection of 5 replicate samples, 16 blank samples, 3 equipment blanks, and 5 laboratory-surrogate spike samples of most constituents. Multiple replicate samples were collected and analyzed for VOCs, pesticides, major and trace constituents, and nutrients, which were the most frequently sampled constituents. Field blanks were collected at about 10 percent of wells to determine whether contamination occurred during sample collection, transport, or analysis. All blanks were processed using $\mathrm{N}_{2}$-purged universal water that was certified for use in the collection of blank samples for VOCs, pesticides, 
nutrients, DOC, major ions, and trace elements. Field blanks were processed using the same procedures and equipment as the environmental samples.

The only organic compounds detected in blank samples were carbon disulfide $\left(\mathrm{CS}_{2}\right)$, benzene, and toluene, which were detected at estimated concentrations (E values, less than the MRL) of $0.07 \mu \mathrm{g} / \mathrm{L}, 0.01 \mu \mathrm{g} / \mathrm{L}$, and $0.088 \mu \mathrm{g} / \mathrm{L}$, respectively, in a field-equipment blank (Appendix 3). Two of those organic compounds also were detected in the blank water, which indicates that either the blank water itself was the source or the blanks were contaminated in the laboratory where the blanks were processed. No other VOCs or pesticides were detected in blank samples. Four inorganic constituents were detected in blanks at concentrations that were greater than the MRLs, including $\mathrm{Cu}, \mathrm{Pb}, \mathrm{Zn}$, and $\mathrm{Al}$. Two additional inorganic constituents, $\mathrm{Ba}$ and $\mathrm{Be}$, were detected at estimated concentrations.

Values from replicate analyses for organic compounds were within analytical uncertainty, with the exception of organic C. Values from replicate analyses for inorganic compounds were within analytical uncertainty for all constituents. Bromide analyzed in several water samples collected from June 2005 to the end of the data collection had a positive bias, on average, compared to historic median values. The bias was likely a result of matrix interferences found in environmental samples; these values were removed from the data set used for this study.

Four surrogate compounds were added at the NWQL to all groundwater, surface-water, and quality-control samples that were analyzed for pesticides, VOCs, and gasoline oxygenates. These included diazinon- $d-10$, isobutyl alcohol, 1,2-dichloroethane- $d$-4, and 1-bromo-4-fluorobenzene. Recoveries that range from 70 to 130 percent generally are considered to be within acceptable limits, although this range can vary considerably for specific compounds. Recoveries for the diazinon- $d-10$ surrogate ranged from 78 to 106 percent. Median percent recoveries for the three other surrogates were as follows: isobutyl alcohol, 91; 1,2-dichloroethane- $d-4,120$; and 1-bromo-4-fluorobenzene, 88 .

\section{Hydrogeologic Setting}

The Pomperaug aquifer system is made up of glacial deposits and fractured bedrock. Glacial stratified deposits are generally the most productive sources of groundwater in the New England area and occur in primary and secondary valleys. Glacial deposits overlie bedrock in all but a very few localized areas. Fractured-bedrock aquifers are located in the uplands, where they are used mostly for domestic supply and are mostly overlain by glacial till, and beneath the glacial stratified deposits in the valleys. In the Pomperaug aquifer system, as in much of New England, these two aquifers are hydraulically connected along valley bedrock contacts, although the flow rate is generally much less in fractured bedrock. The term "glacial aquifer system" herein refers to glacial deposits, including stratified deposits and till, and the underlying or adjacent fractured bedrock.

\section{Bedrock Geology}

Most of the study area is underlain by bedrock of at least two distinct ages and origins: (1) Paleozoic metamorphic rocks, which underlie the uplands east of the Pomperaug River Valley, and (2) Mesozoic basalt and sedimentary rocks, which underlie the valley (fig. 7). The Mesozoic and Paleozoic rocks are separated by the eastern border fault, which runs along a north-flowing segment of South Brook near wells WY86 and WY87. The Pomperaug River watershed lies along the western edge of the Pomperaug Basin, which is similar in character to that of the Hartford Basin in central Connecticut; both of these basins include Mesozoic-age rocks of arkosic sandstone, conglomerate, shale, siltstone, and basalt (Burton, 2006). Sediment grains in the coarse-grained glacial deposits of the Pomperaug Basin indicate a local provenance, including weathered basalt and other Mesozoic rocks and garnet-mica schist and gneiss from surrounding Paleozoic rocks (Burton and others, 2005).

The Mesozoic-age sequence of rocks, formally known as the Pomperaug Group is about $500 \mathrm{~m}$ thick and consists of as many as three basalt layers interbedded with shale, arkosic sandstone, and conglomerate, which dip eastward at various angles but average about $40^{\circ}$ (Burton and others, 2005; Huber and Letourneau, 2006; fig. 7). In general, the rocks within the Pomperaug Group are faulted and fractured and consist of immature feldspathic alluvial and lacustrine closed-basin deposits. The lowermost unit is the South Britain Formation of Late Triassic age that consists of siltstone, sandstone, and conglomerate. Three basalt units have been described, including the East Hill Basalt, the Orenaug Basalt, and the South Brook Basalt. The upper two basalts, the Orenaug and the South Brook Basalts, are geochemically similar to their equivalents in the Hartford Basin to the east (Burton and others, 2005). The Orenaug Basalt is comagmatic with the Holyoke and Preakness Basalts of the Hartford and Newark Basins, respectively (Hurtubise and Puffer, 1983; Philpotts and others, 1996; Burton and others, 2005).

The Cass Formation, which is 35 to $40 \mathrm{~m}$ thick, overlies the East Hill Basalt and consists of buff to black micrite (limestone) and calcareous shale; gray and red siltstone; redbrown and buff, fine- to coarse-grained litharenitic, quartzose, pebble-cobble conglomerate. The limestone unit is organic rich and known for its bitumen-coated fractures (Burton and others, 2005). The Orenaug Basalt is a quartz tholeiite at least $80 \mathrm{~m}$ thick that forms most ridges in the Pomperaug Basin (Burton and others, 2005). Burton and others (2005) report possibly three basalt flow units within the Orenaug Basalt; the middle unit is softer than the others, more susceptible to erosion, and may be related to the bedrock topographic lows between ridges. The middle unit of the Orenaug Basalt 


\section{EXPLANATION}

\begin{tabular}{ll}
\hline Js & South Brook basalt \\
\hline Jw & White Oaks formation \\
Jo & Orenaug basalt \\
Jc & Cass formation \\
Je & East Hill basalt \\
Trs & South Britain formation
\end{tabular}

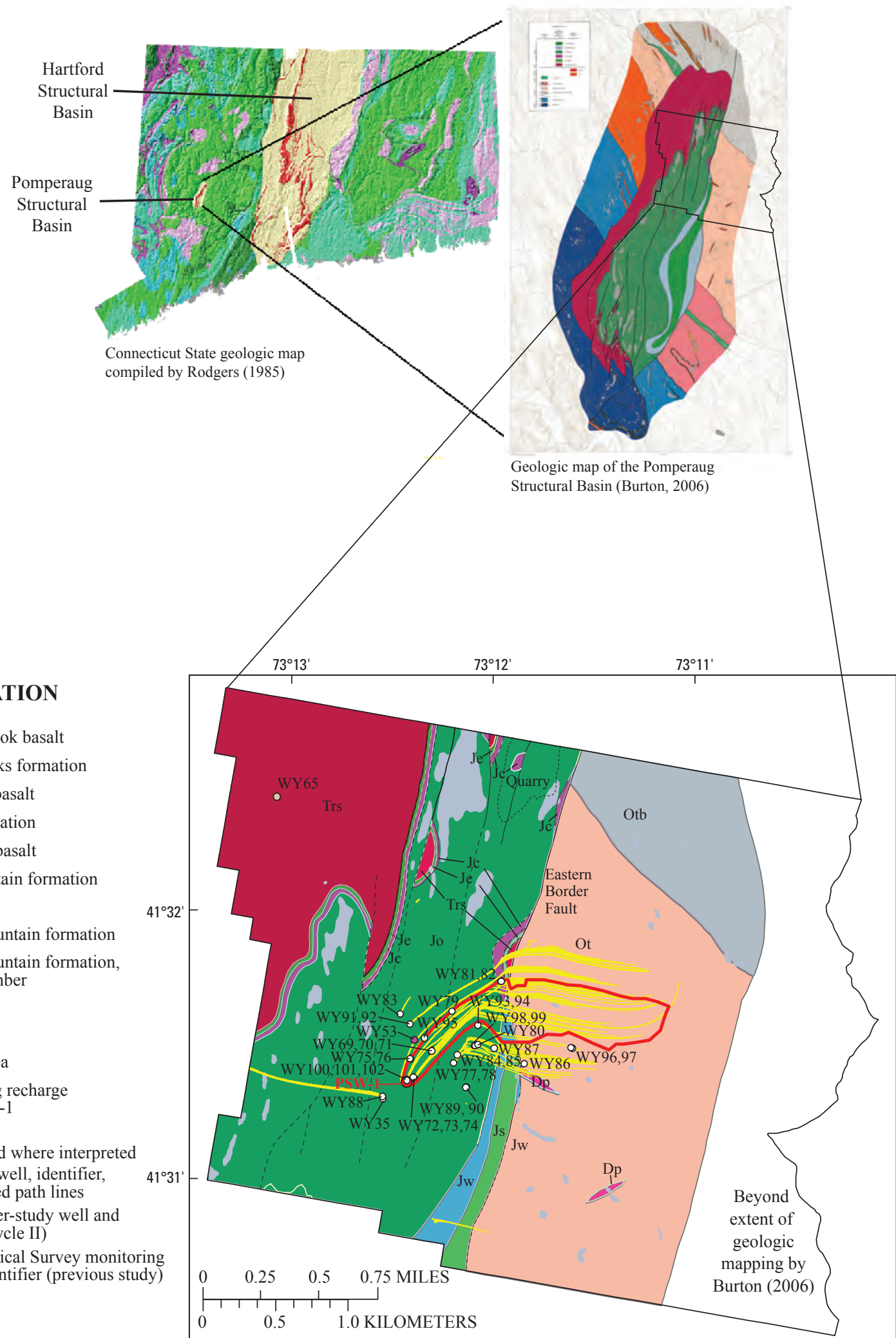

Figure 7. Bedrock geology of the Pomperaug and Connecticut structural basins and the study area, and simulated paths of flow to monitoring wells and the modeled contributing recharge area to PSW-1 based on particle tracking with MODPATH (Starn and Brown, 2007), Woodbury, Connecticut. 
underlies much of the study area and contains abundant plagioclase and amygdules filled with carbonate, prehnite, and chalcedony, as observed in WY87. The White Oaks Formation, which overlies the Orenaug Basalt, consists of a black lacustrine shale, conglomerate, and pebbly arkose and correlates to the East Berlin Formation of the Hartford Basin, the Turners Falls Formation of the Deerfield Basin, and the Towaco Formation of the Newark Basin (Burton and others, 2005). The third basalt, the South Brook Basalt, overlies the White Oaks Formation and consists of a highly altered, vesicular basalt; exposures along South Brook are strongly altered by secondary growth of calcite, dolomite, and other minerals, and contain at least two $\mathrm{Cu}$ prospects.

Sedimentary rocks in the Hartford and Pomperaug Basins consist of a mixture of three mineralogic end members - (1) an arkosic (granitic) detritus made of about 58 percent quartz, 40 percent feldspar ( 31 percent microcline, 9 percent Na-plagioclase) and 2 percent mica; (2) a mixture of white and hematitic clay consisting of about 60 percent kaolinite, 6 percent gibbsite, 12 percent sericite-illite, and 20 percent hematite; and (3) a calcite cement (Krynine, 1950). Ferroan dolomite and dolomite cements also were found almost exclusively in the lacustrine, playa, and minor fluvial sandstones of the Hartford Basin (Hubert and others, 1992). Rocks in the Hartford Basin generally are illitic, with subordinate amounts of chlorite (April, 1981); smectites and mixed-layer clays are the predominant clays in the East Berlin Formation (Gottfried and Kotra, 1988). Most samples of carbonaceous shales from the Newark Supergroup in the eastern Mesozoic Basins are not metal rich, aside from $\mathrm{Cu}$; trace metals in these rocks mostly are associated with the inorganic clay fraction and not with organic matter (Dean, 1988). Whole-rock geochemical analysis of shale from several members of the Passaic Formation in New Jersey yielded maximum concentrations of As that ranged from $13 \mu \mathrm{g} / \mathrm{g}$ in red shale to $50 \mu \mathrm{g} / \mathrm{g}$ in gray shale and $130 \mu \mathrm{g} / \mathrm{g}$ in black shale, with pyrite being the major source in black shales (Serfes, 2004).

Nonmarine sediments that were deposited in the Pomperaug Basin during the mainly arid Late Triassic and Early Jurassic Periods consist of evaporates and caliche, in addition to arkoses and shales (LeTourneau and Huber, 2006). Downward circulating diagenetic fluids associated with the emplacement of diabase dikes and sills, and basalt flows (Gray, 1988; Huber and MacDonald, 1992) resulted in concentration of salts and metals and provided a Na-rich brine responsible for the formation of analcime and albite (van de Kamp and Leake, 1996), as well as chert, quartz, and albite overgrowths; hematite, illite and chlorite cement; carbonates; and metaliferous minerals in Mesozoic rocks of the Hartford Basin (Gray, 1988; Merino and others, 1997). Trace metals weathered from mafic minerals were concentrated in the brine and ultimately deposited in the Na-rich shales of the Hartford (and presumably Pomperaug), Newark, and Deerfield Basins (van de Kamp and Leake, 1996). Although no substantial evaporite deposits have been found in the shales of the Hartford Basin, probably as a result of dissolution by groundwater, some gypsum $\left(\mathrm{CaSO}_{4} \times 2 \mathrm{H}_{2} \mathrm{O}\right)$ was found in the East Berlin Formation of the Hartford Basin (Hubert and others, 1978), and molds of anhydrite $\left(\mathrm{CaSO}_{4}\right)$ crystals are common in basalts of the Pomperaug Basin (Garabedian and others, 1996). Small, stratabound deposits and fault/replacement deposits of $\mathrm{Cu}$ and $\mathrm{Zn}$ are widespread in sandstones beneath or adjacent to basalts in the vicinity of the Hartford Basin (Robinson and Sears, 1988).

\section{Surficial Deposits}

Surficial deposits in the study area consist of glacial till, glacial stratified deposits, and postglacial flood-plain deposits (alluvium and swamp). Most of the weathered rock and saprolite that mantled the bedrock surface probably was removed by the Illinois and Wisconsin Episodes ice sheets that covered Connecticut (Stone and others, 2005). Glacial stratified deposits composed of gravel, sand, silt, and clay were sorted and deposited by flowing glacial meltwater (Stone and others, 2005). Glacial stratified deposits are as much as $23 \mathrm{~m}$ thick beneath the study area but can be as much as $46 \mathrm{~m}$ thick in other parts of the Pomperaug aquifer system (Mazzaferro, 1986b) typically associated with ice-contact positions and morphosequences (Koteff and Pessl, 1981; Randall, 2001; and Stone and others, 2005). A companion report (Starn and Brown, 2007) describes the glacial stratigraphy in more detail.

The source rocks for glacial deposits, on the basis of the color of the sediments and the rock fragments and gravels within (Appendix 1), appear to consist of a mixture of gray and greenish gray basalt (Orenaug, East Hill, or South Brook), light to medium gray gneiss and schist (probably Taine Mountain Formation or Rowe Schist), granite, reddish brown arkose (probably South Britain or White Oaks Formations), and black and reddish silty sand (probably from the Cass Formation), according to Burton and others (2005). The sediments at WY83 are generally coarse but include a 0.15 -m-thick, blackish-red layer that is high in silt and clay. The Cass Formation includes organic-rich (bitumen) lacustrine shales and siltstones that may be the source rock. The graincoating extractions indicated relatively high concentrations of $\mathrm{U}$ and As, which can be common in Newark Supergroup rocks (Vine and Tourtelot, 1970; Coveney and Martin, 1983).

\section{Hydrology}

Precipitation in the Pomperaug River Watershed averages about $117 \mathrm{~cm} / \mathrm{yr}$ (centimeters per year; Randall, 1996). About $53 \mathrm{~cm} / \mathrm{yr}$ of that is lost to evaporation or transpiration; therefore, about $64 \mathrm{~cm} / \mathrm{yr}$ of water potentially could flow through the groundwater system (Starn and Brown, 2007). Generally, there is more recharge in spring and fall than in summer and winter. Sources of groundwater recharge in the study area include precipitation that infiltrates the ground 
and flows to the water table, streamflow where water flows from the stream to the water table, and subsurface flow from adjacent areas. Infiltrating precipitation recharges groundwater in the study area at different rates depending on geologic, topographic, and climatic factors (D.M. Bjerklie, U.S. Geological Survey, written commun., 2007). Geologic and topographic factors, such as surface permeability and slope, determine the rate of recharge in different areas. Climatic factors, such as rainfall and temperature, affect seasonal differences in the rate of recharge.

Water use in the Pomperaug River watershed, as in much of New England, varies by topography and demographics. Residents in the primary and secondary valleys of Connecticut generally rely on groundwater from public-supply wells. The exception to this is major cities, such as Hartford, New Haven, and Bridgeport (populations greater than 100,000), which generally rely on surface water from reservoirs or rivers. Residents in upland areas mostly rely on groundwater derived from fractured bedrock, either from domestic wells or small community public-supply wells. Most people in Woodbury live in the valley bottom and are supplied by groundwater from two community public-supply wells, including PSW-1 that is the focus of the contributing area studied here. Community public-supply wells are present in the uplands (see Lyford and others, 2007), but much of the remaining withdrawals are from domestic wells in fractured bedrock.

Most of the groundwater withdrawn in the study area is returned to the subsurface as flow through septic-tank drainfields, although a small portion is applied to lawns, and a portion may recharge the groundwater system. In upland areas, the net effect of pumping from domestic wells is to redistribute water from bedrock fractures to shallow soils developed in glacial till. More of the water in the shallow subsurface evaporates or flows to local streams than would be the case if the water was not withdrawn from the bedrock aquifer (Starn and Brown, 2007).

Groundwater flows laterally through till in upland areas to upland streams and wetlands, downward into bedrock fractures, and (or) laterally into glacial stratified deposits in the valley floor and to the Pomperaug River (figs. 2 and 3). Groundwater in glacial stratified deposits discharges to the Pomperaug River, to adjacent ponds formed in abandoned gravel quarries along the river, and to PSW-1 (fig. 2). A gradual increase in withdrawals from in PSW-1 during the past 5 years is apparent (Starn and Brown, 2007) and probably reflects increased residential demand. Particle simulations generated with MODPATH (Pollack, 1994) were used to estimate the contributing areas on the basis of 10 particles that were backtracked from each monitoring well (figs. 4 and 7 , and table 9; Starn and Brown, 2007).

EM flowmeter measurements in a 20.7-m deep borehole located near PSW-1 showed upward flow during nonpumping conditions in two discrete zones near the top and bottom of the PSW-1 screen. These zones coincide with coarse sand and gravel, as indicated by the gamma log and by geologic log descriptions. There was no flow in the silty sand and very fine sand deposits between these two zones of preferential flow. The flow diminished almost completely during pumping at PSW-1, altering the natural upward gradient, but preferential flow during nonpumping conditions can affect the source of water to the well. Lithologic facies, as well as sediment color, were used to explain much of the heterogeneity in permeability and extractable Fe and $\mathrm{Mn}$ in a glacial fluvial aquifer (Sturgeon and others, 2006). The texture and structure of the glacial deposits was defined in detail through sediment-sample descriptions, results of interpretation of the geophysical log and EM flowmeter log, and chemical profiles in the continuously screened well WY103 (fig. 8). The flowmeter log shows increased flow in the zones between the 18.1-m and 15.1-m depths in both zones and between the 12-m and $9-\mathrm{m}$ depths. It appears that the stratified deposits contain some zones of layers, probably only tens of centimeters thick, that are more permeable than adjacent zones and function as the primary pathways for groundwater flow. The water chemistry is different in the 18.1-m-to-15.1-m zone that is associated with higher flow than in adjacent zones; the locally high specific conductance could be caused by anthropogenic contaminant sources such as recharge from a septic-tank drainfield. The DO concentrations in this zone also are lower than those in adjacent zones and may result from reduction by organic $\mathrm{C}$.

The four monitoring wells that were drilled in bedrock (figs. 2 and 3) provided information on bedrock fractures and fracture flow. Vertical fractures in both the Mesozoic rocks in the Pomperaug Basin and the Paleozoic rocks in the adjacent uplands trend north-northeast (Burton and others, 2005) and likely affect groundwater flow at a local scale. Stress-relief fractures are nearly horizontal and generally decrease with depth, but probably are important on the scale of a zone of contribution (Starn and Stone, 2005). Groundwater from fractures can discharge directly to surface water where bedrock is exposed, but more often, it discharges either laterally or vertically into glacial deposits in the valley. Some (about 4 percent) flow in upland areas discharges to public- and domestic-supply wells (Starn and Brown, 2007). Paleozoic rocks to the east of the eastern border fault are highly fractured (Burton and others, 2005), although most of the fractures observed in well WY86 are filled with secondary minerals. Fractures in the Orenaug Basalt tend to be filled with calcite and other minerals, and usually are not permeable. An eolian sandstone unit within the upper Cass Formation, directly beneath the Orenaug Basalt, has a relatively high porosity and permeability and may be a substantial pathway for preferential flow (Burton and others, 2005). Interbedded siltstone and fine sandstone units of the White Oaks Formation also contain water-bearing fractures, as observed using an EM flowmeter in a deep borehole in Southbury (W.C. Burton, U.S. Geological Survey, written commun., 2006). The South Brook Basalt is highly vesicular and may be permeable (Burton and others, 2005). 


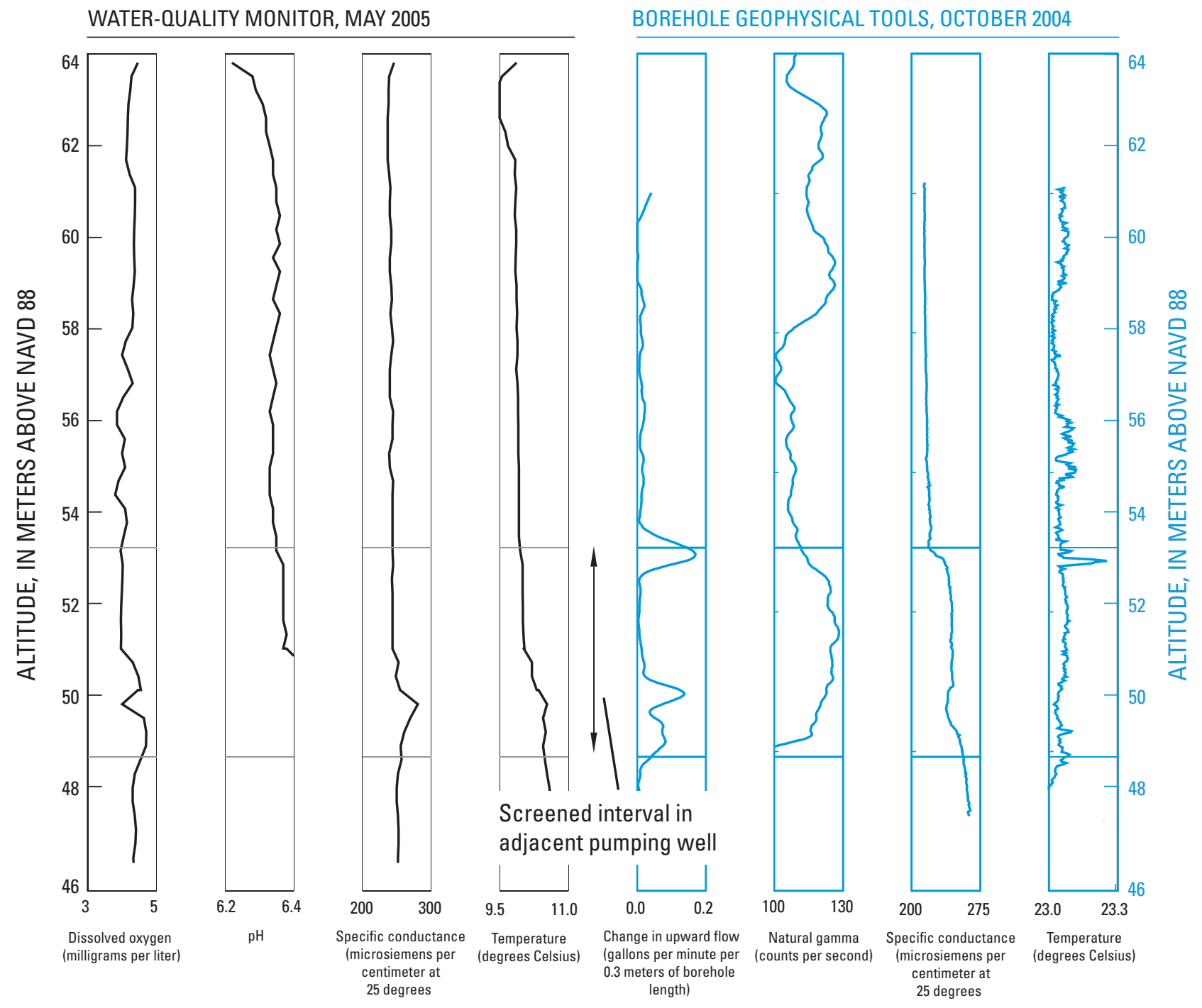

Figure 8. Selected groundwater characteristics measured in well WY103, May 2005, with a water-quality monitor, and October 2004, with borehole geophysical tools, in relation to altitude, Woodbury, Connecticut.

\section{Aquifer Chemistry}

The chemical composition of groundwater results from reactions with aquifer materials, anthropogenic-constituent sources, rates of recharge, and directions and rates of groundwater flow. The sections below describe (1) solidphase geochemistry to characterize aquifer material and its potential for weathering and other geochemical reactions in the aquifer system; (2) groundwater chemistry and age, and their spatial distribution to identify the sources and pathways of groundwater; and (3) groundwater chemistry in relation to groundwater-flow data to evaluate pathways to PSW-1. This characterization allows for improved understanding of groundwater chemistry in different parts of the aquifer system and chemical transport to a public-supply well.

\section{Solid-Phase Geochemistry}

The mineralogy, $\mathrm{C}$ content, acid-extractable fraction, and sorption behavior of subsurface materials were analyzed to help assess their effects on groundwater chemistry through aquifer weathering and other geochemical reactions, such as adsorption. Analyses were done on core samples from the glacial aquifer and from the underlying and adjacent bedrock, which typically is the "source rock" for the surficial deposits. 


\section{Mineralogy}

The mineralogy of the unconsolidated deposits is largely reflective of the mineral composition of the bedrock sources. Natural constituents, including alkalinity, Fe, Mn, As, U, $\mathrm{Ca}, \mathrm{HCO}_{3}^{-}$, and $\mathrm{DOC}$, can be preferentially derived from certain source rocks. The type and distribution of the bedrock, therefore, can have a substantial effect on groundwater chemistry in the glacial aquifer. The mineralogy of surficial deposits is highly variable across Connecticut but generally is similar to adjacent bedrock (Stone and others, 2005), except that surficial deposits have a higher percentage of quartz and other minerals that are resistant to weathering. Fragments of distinctive sedimentary and igneous rocks of the Pomperaug Basin were deposited in an "indicator fan" of glacial deposits that extend generally to about $13 \mathrm{~km}$ to the southeast of the basin (Pessl, 1970).

The x-ray diffractometry of whole-sample mounts from glacial deposits indicates the presence of mostly quartz, plagioclase (generally albite), and $\mathrm{K}$ feldspar for the bulk mineralogy (table 3). The dominance of Na-rich plagioclase (albite and oligoclase) over $\mathrm{K}$ feldspar is in accordance with studies of late Triassic sandstones of the Hartford and Pomperaug Basins (Krynine, 1950; Weddle and Hubert, 1983; Hubert and others, 1992) and in rocks of the Newark Basin (Tabakh and Schreiber, 1998), where similar albite-rich sandstones were attributed to circulation of Na-rich fluids in the distant past. Muscovite and some biotite were abundant locally, particularly in sediments derived from bedrock such as the Taine Mountain Formation, pegmatite, and possibly the Cass and White Oaks Formations. Calcite and calcic plagioclase was observed in mineral-filled fractures of the Orenaug Basalt. Calcite also is present in calcite-bearing units of the South Britain, Cass, and White Oaks Formations of the Pomperaug Basin (Burton and others, 2005). Calcite was detected in trace amounts (table 3 ) in the deeper glacial deposits (WY75), possibly from mineral-filled fractures of underlying Orenaug Basalt or from the Cass Formation. Hornblende was detected in trace amounts at four sites, WY77, WY92, WY94, and WY100. Results of XRD analysis of the clay fractions, which include particles less than $1 \mu \mathrm{m}$ in diameter, indicated the presence of mainly illite, smectite, and kaolinite, with lesser amounts of vermiculite, chlorite, intergrade smectite, and trace amounts of hornblende. Vermiculite is one of the major clay components in gneiss from WY92 and WY94, with smaller amounts present in WY100 (table 3). Goethite was not detected in either bulk or clay-size fraction of the 14 XRD samples, although samples from WY81 and WY77 yielded minor amounts of ultrafine material, less than $0.03 \mu \mathrm{m}$ fraction, that consisted mainly of poorly crystalline goethite and total clay, with a trace of hornblende. Secondary Fe oxides were observed in thin sections as oxidized portions of primary Fe oxides, as hematite coatings and stains on other minerals, as hematiterich matrix of rock fragments, and as fracture-fill material. Hematite was observed in several heavy-mineral separates, and poorly crystalline ferric oxyhydroxides were determined in acid extractions, as discussed in the next section. Fe-sulfide minerals (FeS and (or) $\mathrm{FeS}_{2}$ ) were observed in one heavymineral separate and some sulfide extractions, and generally were associated with localized reducing zones beneath wetlands (WY100) or near the water table (WY94; tables 4 and 5).

Results of heavy-mineral analysis were used to help determine the presence of more reactive mineral phases that might affect groundwater chemistry (table 4). The small number of samples precludes a detailed analysis of provenance. The heavy-mineral content of sample fractions from glacial deposits is estimated to range from 2 to 10 percent of total sample weight. Heavy minerals in the slightly magnetic to nonmagnetic fractions include quartz (that contains inclusions or is part of rock fragments), amphibole/ pyroxene, zircon, sphene, epidote, biotite, muscovite, garnet, kyanite, rutile, tourmaline, and apatite (table 4).

\section{Sediment Extractions}

Acid extractions were performed on sediments and rock samples to determine concentrations of $\mathrm{Fe}, \mathrm{Mn}$, and other trace elements, including $\mathrm{As}, \mathrm{U}, \mathrm{Cu}$, and $\mathrm{Pb}$, within solid phases (table 5). Concentrations and oxidation states of Fe and Mn can be used to assess the redox environment in the part of the aquifer from which the sample was taken. Concentrations of 0.5-M HCl-HA-extractable Fe (total) coatings (780 to $1,500 \mu \mathrm{g} / \mathrm{g}$ of sample) and 6-M $\mathrm{HCl}$-extractable Fe (total) coatings (490 to $11,000 \mu \mathrm{g} / \mathrm{g}$ of sample) indicate that sediments can be rich in Fe and generally are consistent with predominantly oxic conditions (table 5). The 6-M HCl-extractable Fe (total) fraction, which indicates the amounts of both crystalline and poorly crystalline Fe coating, generally is 5 to 10 times greater than the 0.5-M HCl-HA-extractable Fe, which indicates the amount of poorly crystalline Fe(III) in the sample and also, presumably, the most microbially reactive Fe fraction (table 5). Concentrations of 6-M HCl-extractable Mn (total) coatings (less than 0.1 to $360 \mu \mathrm{g} / \mathrm{g}$ of sediment) generally are 20 to 120 times smaller than those of 6-M HCl-extractable Fe (total) coatings (table 5), and the coatings generally are consistent with relative concentrations of dissolved $\mathrm{Fe}$ and $\mathrm{Mn}$ in oxic and Fe- or Mn-reducing conditions in groundwater. In the water samples that indicated reducing conditions, the dissolved Mn concentrations were 2 to 90 times higher than were the dissolved Fe concentrations.

Concentrations in the $6-\mathrm{M} \mathrm{HCl}$ extractions of sediments in samples from WY100 at the 16-m depth were high relative to those in sediments from other sites for almost all constituents analyzed, including $\mathrm{Al}, \mathrm{Ca}, \mathrm{Mg}, \mathrm{K}, \mathrm{Na}, \mathrm{Cr}$, $\mathrm{Cu}, \mathrm{U}, \mathrm{Ni}$, and $\mathrm{V}$ (table 5). The 6- $\mathrm{M} \mathrm{HCl}$ extractions for sediments from WY90 at the 6.7-m depth also yielded high concentrations of $\mathrm{Ca}$, as well as $\mathrm{Mg}, \mathrm{Na}, \mathrm{K}, \mathrm{Cu}$, and $\mathrm{Al}$, which may reflect the composition of the till, the proximity to bedrock, and (or) the relatively high concentrations of 
Table 3. Relative mineralogical abundances, based on x-ray diffraction (XRD), of core samples from boreholes in the Woodbury, Connecticut, study area, 2003-04.

[Lower integers indicate higher relative abundance. Zero indicates absence; ID, identifier; tr, or trace, indicates less than 1 percent; tr?, indicates a possible trace; bls, below land surface; bedrock wells shaded gray]

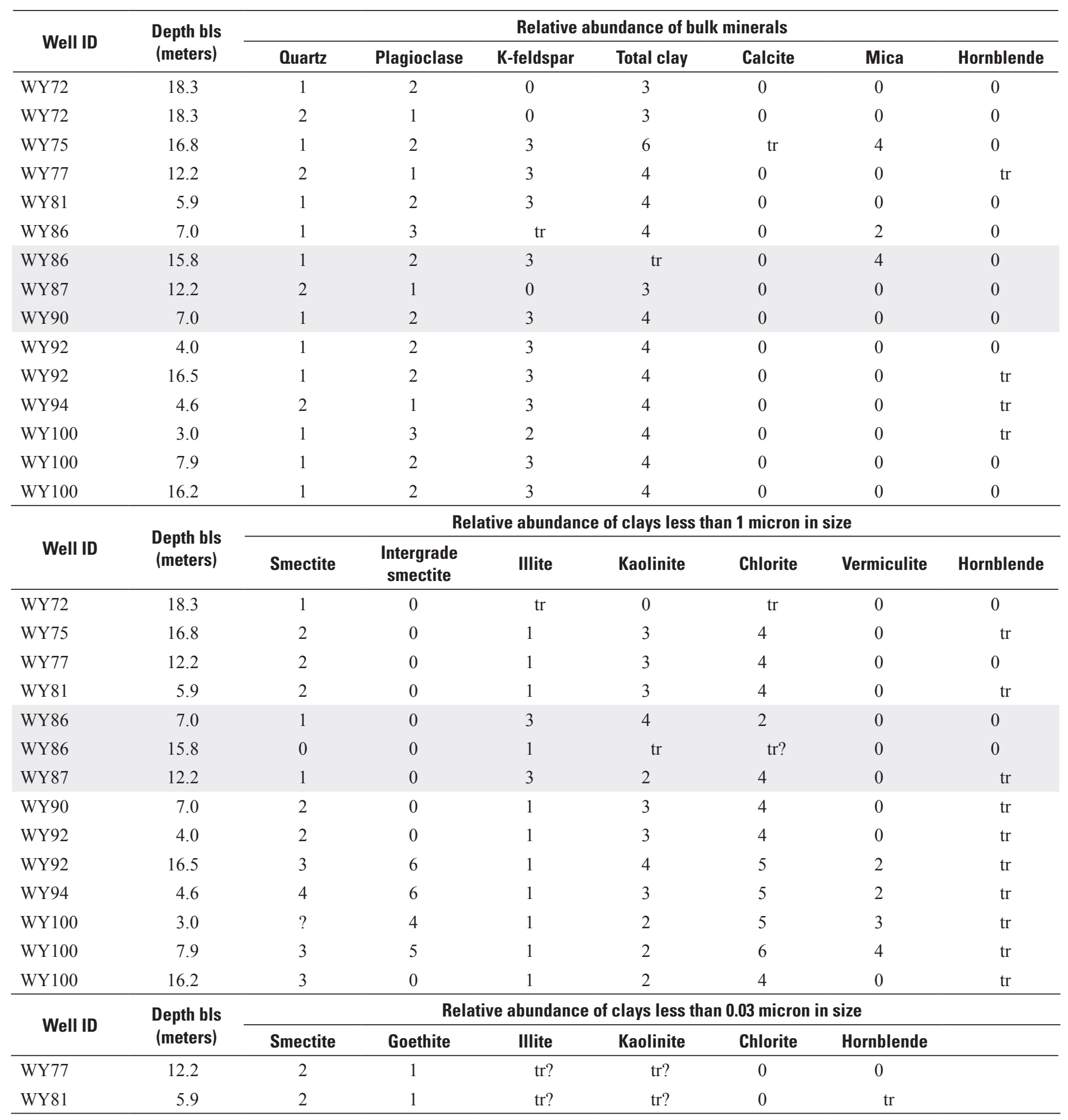


Table 4. Mineralogy of slightly magnetic and nonmagnetic heavy-mineral separates based on analysis by petrography and spectra of aquifer material from boreholes in the study area, Woodbury, Connecticut, 2003-04.

[ID, indicates identifier; bls, below land surface. Separated fractions: magnetic, C1; slightly magnetic, C2; nonmagnetic, C3; \%, percent.]

\begin{tabular}{|c|c|c|}
\hline Well ID & $\begin{array}{l}\text { Depth bls } \\
\text { (meters) }\end{array}$ & Heavy-mineral separates \\
\hline WY75 & 16.8 & $\begin{array}{l}\text { C-3: } 40 \% \text { sphene, } 30 \% \text { amphibole/pyroxene, } 10 \% \text { quartz, trace tourmaline, epidote, muscovite } \\
\text { C-2: } 50 \% \text { garnet, } 50 \% \text { amphibole/pyroxene, trace epidote }\end{array}$ \\
\hline WY77 & 12.2 & $\begin{array}{l}\text { C-3: } 90 \% \text { quartz, } 10 \% \text { amphibole/pyroxene C-2: } 90 \% \text { amphibole/pyroxene } 10 \% \text { (garnet, } \\
\text { epidote, sphene) }\end{array}$ \\
\hline WY94 & 4.6 & C-3: $80 \%$ quartz, $20 \%$ amphibole/pyroxene, trace sphene, zircon, muscovite, and pyrite \\
\hline WY100 & 7.9 & $\begin{array}{l}\text { C-3: } 30 \% \text { amphibole/pyroxene, } 30 \% \text { sphene, } 20 \% \text { quartz, } 10 \% \text { (zircon, muscovite, hematite, } \\
\text { garnet) C-2: } 80 \% \text { garnet, } 10 \% \text { amphibole/pyroxene, and 10\% hematite }\end{array}$ \\
\hline WY100 & 16.2 & $\begin{array}{l}\text { C-3: } 80 \% \text { amphibole/pyroxene, } 10 \% \text { zircon, } 10 \% \text { (quartz, sphene, apatite), and trace epidote } \\
\text { and tourmaline }\end{array}$ \\
\hline
\end{tabular}

dissolved solids derived from septic-tank drainfields. The 6-M HCl extractions for sediments from WY83 had relatively high concentrations of $\mathrm{U}(0.5 \mu \mathrm{g} / \mathrm{g})$, As $(1.6 \mu \mathrm{g} / \mathrm{g})$, and $\mathrm{Cd}$ $(0.07 \mu \mathrm{g} / \mathrm{g})$, but the 10 -percent $\mathrm{HNO}_{3}$ extractions had even higher concentrations of $\mathrm{U}(11 \mu \mathrm{g} / \mathrm{g})$ and $\mathrm{Cd}(9.6 \mu \mathrm{g} / \mathrm{g})$. The discrepancy between the two types of extractions probably reflects the effect of the acid type and strength on the leaching of mineral coatings, which can vary considerably (Heron and others, 1994). Cd concentrations were high in the Cass Formation relative to that in other rocks in the Pomperaug Basin, based on whole-rock analysis (W.C. Burton, U.S. Geological Survey, written commun., 2006). Arsenic concentrations in 10-percent $\mathrm{HNO}_{3}$ extractions of sediments from WY83 also were much higher than in other sediments, indicating that the sediments were derived from the Cass Formation, which has mapped units less than $200 \mathrm{~m}$ to the northwest (fig. 7). Units in the Newark Supergroup can be organic rich and have high concentrations of As, U, and other trace elements (Vine and Tourtelot, 1970; Coveney and Martin, 1983), although trace elements in most samples of carbonaceous (organic-rich) shales of the Newark Supergroup are associated with the inorganic clay fraction and not directly with organic matter (Dean, 1988). For example, Szabo and Zapecza (1991) observed U enrichment in comparable calcareous black mudstone units within the Newark Supergroup of central New Jersey. Turner-Peterson (1977) hypothesized that uranyl ions were carried into the Newark Basin by groundwater, then the $U$ was reduced by humic matter and dissolved sulfides $\left(\mathrm{H}_{2} \mathrm{~S}\right.$ and $\left.\mathrm{HS}^{-}\right)$from $\mathrm{U}(\mathrm{VI})$ to $\mathrm{U}(\mathrm{IV})$, thereby decreasing the solubility and immobilizing $\mathrm{U}$ in the organic-rich sediments. A similar enrichment may have occurred in the Pomperaug Basin, since U-rich crystalline rocks and organic-rich sediments were both present in the source and the sink for U. Dilute waters migrated into the depositional basin where evaporative concentration during semiarid to arid climate conditions yielded brines; Hubert and others (1978) found ghost clasts of halite and gypsum that had been replaced by calcite or silica, indicating the past existence of brine.

A rock sample from a fractured pegmatite at WY86 near the eastern border fault had high concentrations of constituents extracted with 10-percent $\mathrm{HNO}_{3}$, including As $(0.29 \mu \mathrm{g} / \mathrm{g})$ and $\mathrm{U}(0.45 \mu \mathrm{g} / \mathrm{g})$, that were high compared with concentrations extracted from the Taine Mountain Formation host rock of $0.098 \mu \mathrm{g} / \mathrm{g}$ for As and $0.44 \mu \mathrm{g} / \mathrm{g}$ for $\mathrm{U}$ (table 5). The pegmatite extends from depths of $13 \mathrm{~m}$ to $30 \mathrm{~m}$ below land surface in the host rock schist/gneiss (Taine Mountain Formation) (figs. 2, 3, and fig. 2-1). The Taine Mountain Formation had the highest concentration of $\mathrm{Pb}(8.3 \mu \mathrm{g} / \mathrm{g})$ and a high concentration of $\mathrm{Fe}(4,200 \mu \mathrm{g} / \mathrm{g})$ in extracts leached with 6-M HCl (table 5). Crystalline rocks, particularly biotite-muscovite (two-mica) granite and other high-grade metamorphic rocks, typically have high concentrations of $U$ and ${ }^{222} \mathrm{Rn}$ (Hollocher and Yuskaitis, 1993). Intrusive bodies of two-mica granite or pegmatite are common north and west of the basin (Burton and others, 2005); an intrusive rock north of the study area, mapped as the Nonewaug Granite (Gates, 1954), contains high concentrations of ${ }^{222} \mathrm{Rn}$ and $\mathrm{U}$ (Dupuy and others, 1991). Concentrations of ${ }^{222} \mathrm{Rn}$ and $\mathrm{U}$ in the northeastern glacial aquifers and New England crystalline aquifers are among the highest for principal aquifers of the United States (Ayotte and others, 2007).

A rock sample from well WY87 was chemically correlated to the Orenaug Basalt by Burton and others (2005). 
Table 5. Selected constituents in acid extractions and organic carbon, and analysis of bulk density and pore-water constituents of aquifer material from boreholes in the study area, Woodbury, Connecticut, 2003-04.

[Concentrations in micrograms per gram of sediment unless otherwise indicated; ID, indicates identifier; bls, below land surface; M, moles per liter; g/cc, grams per cubic centimeter; \%, percent; Fe, iron; Mn, manganese; As, arsenic; $\mathrm{U}$, uranium; $\mathrm{Al}$, aluminum; Ca, calcium; $\mathrm{Cr}$, chromium; Cu, copper; $\mathrm{K}$, potassium; $\mathrm{Mg}$, magnesium; $\mathrm{Na}$, sodium; Ni, nickel; $\mathrm{Pb}$, lead; $\mathrm{V}$, vanadium; $\mathrm{Zn}$, zinc; $\mathrm{Cd}$, cadmium; $\mathrm{HNO}_{3}$, nitric acid; $\mathrm{HCl}$, hydrochloric acid; $\mathrm{HA}$, hydroxylamine; $\delta^{13} \mathrm{C}$, delta carbon-13; C, carbon; $\delta^{15} \mathrm{~N}$, delta nitrogen-15; --, not measured; bedrock wells shaded gray; <, less than]

\begin{tabular}{|c|c|c|c|c|c|c|c|c|c|c|c|c|c|c|c|c|c|c|}
\hline \multirow[b]{2}{*}{$\begin{array}{l}\text { Well } \\
\text { ID }\end{array}$} & \multirow[b]{2}{*}{$\begin{array}{c}\text { Depth } \\
\text { bls } \\
\text { (meters) }\end{array}$} & \multicolumn{17}{|c|}{ Chemical extractions } \\
\hline & & $\begin{array}{c}\mathrm{Fe}(\mathrm{II}) \\
(0.5-\mathrm{M} \\
\mathrm{HCI})^{1}\end{array}$ & 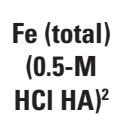 & $\mathrm{Fe}(\mathrm{III})^{3}$ & 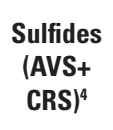 & $\begin{array}{c}\mathrm{Fe} \\
(10 \% \\
\left.\mathrm{HNO}_{3}\right)^{5}\end{array}$ & $\begin{array}{c}\mathrm{Mn} \\
(10 \% \\
\left.\mathrm{HNO}_{3}\right)\end{array}$ & $\begin{array}{c}\text { As } \\
(10 \% \\
\left.\mathrm{HNO}_{3}\right)\end{array}$ & $\begin{array}{c}\mathrm{U} \\
(10 \% \\
\left.\mathrm{HNO}_{3}\right)\end{array}$ & $\begin{array}{c}\text { Cd } \\
(10 \% \\
\left.\mathrm{HNO}_{3}\right)\end{array}$ & $\begin{array}{c}\mathrm{Pb} \\
(6-\mathrm{M} \\
\mathrm{HCI})^{6}\end{array}$ & $\begin{array}{c}\mathrm{Fe} \\
(6-\mathrm{M} \\
\mathrm{HCl})\end{array}$ & $\begin{array}{c}\text { Mn } \\
\text { (6-M } \\
\text { HCl) }\end{array}$ & $\begin{array}{c}U \\
(6-M \\
H C I)\end{array}$ & $\begin{array}{c}\text { Al } \\
\text { (6-M } \\
\mathrm{HCl})\end{array}$ & $\begin{array}{c}\text { Ca } \\
(6-M \\
H C I)\end{array}$ & $\begin{array}{c}\mathrm{Cr} \\
(6-\mathrm{M} \\
\mathrm{HCl})\end{array}$ & $\begin{array}{c}\mathrm{Cu} \\
\text { (6-M } \\
\mathrm{HCI})\end{array}$ \\
\hline WY72 & 0.3 & -- & -- & -- & -- & -- & -- & -- & -- & -- & -- & -- & -- & -- & -- & -- & -- & -- \\
\hline WY72 & 0.9 & -- & -- & -- & -- & -- & -- & -- & -- & -- & -- & -- & -- & -- & -- & -- & -- & -- \\
\hline WY72 & 1.5 & -- & -- & -- & -- & -- & -- & -- & -- & -- & -- & -- & -- & -- & -- & -- & -- & -- \\
\hline WY72 & 2.1 & -- & -- & -- & -- & -- & -- & -- & -- & -- & -- & -- & -- & -- & -- & -- & -- & -- \\
\hline WY72 & 18.3 & -- & -- & -- & -- & -- & -- & -- & -- & -- & -- & -- & -- & -- & -- & -- & -- & -- \\
\hline WY75 & 0.3 & -- & -- & -- & -- & -- & -- & -- & -- & -- & -- & -- & -- & -- & -- & -- & -- & -- \\
\hline WY75 & 0.9 & -- & -- & -- & -- & -- & -- & -- & -- & -- & -- & -- & -- & -- & -- & -- & -- & -- \\
\hline WY75 & 1.5 & -- & -- & -- & -- & -- & -- & -- & -- & -- & -- & -- & -- & -- & -- & -- & -- & -- \\
\hline WY75 & 2.1 & -- & -- & -- & -- & -- & -- & -- & -- & -- & -- & -- & -- & -- & -- & -- & -- & -- \\
\hline WY75 & 17.1 & 780 & 670 & -110 & 0.76 & 2,100 & 110 & 0.071 & 0.093 & 6.4 & 0.96 & 5,400 & 51 & 0.20 & 2,000 & 740 & 3.8 & 4.4 \\
\hline WY77 & 12.5 & 840 & 790 & -50 & 0.84 & 2,300 & 170 & 0.12 & 0.380 & 10 & 1.30 & 5,100 & 80 & 0.41 & 2,700 & 800 & 4.7 & 3.9 \\
\hline WY 81 & 0.3 & -- & -- & -- & -- & -- & -- & -- & -- & -- & -- & -- & -- & -- & -- & -- & -- & -- \\
\hline WY 81 & 2.1 & -- & -- & -- & -- & -- & -- & -- & -- & -- & -- & -- & -- & -- & -- & -- & -- & -- \\
\hline WY 81 & 3.4 & -- & -- & -- & -- & -- & -- & -- & -- & -- & -- & -- & -- & -- & -- & -- & -- & -- \\
\hline WY 81 & 4.0 & -- & -- & -- & -- & -- & -- & -- & -- & -- & -- & -- & -- & -- & -- & -- & -- & -- \\
\hline WY 81 & 5.9 & 1,500 & 1,500 & 0 & 1.5 & 2,200 & 180 & 0.10 & 0.210 & 11 & 1.60 & 5,500 & 109 & 0.41 & 2,736 & 981 & 5.0 & 3.5 \\
\hline WY83 & 6.4 & -- & -- & -- & -- & -- & -- & 1.60 & 11 & 10 & 4.79 & -- & -- & 0.07 & -- & -- & -- & -- \\
\hline WY83 & 7.9 & -- & -- & -- & -- & -- & -- & -- & -- & -- & -- & -- & -- & -- & -- & -- & -- & -- \\
\hline WY83 & 8.1 & -- & -- & -- & -- & -- & -- & -- & -- & -- & -- & 22,000 & 150 & 0.53 & 4,700 & 1,300 & 8.2 & 10 \\
\hline WY86 & 6.9 & -- & -- & -- & -- & -- & -- & 0.098 & 0.44 & 18 & 8.45 & 4,200 & 62 & 0.39 & 2,600 & 1,200 & 3.0 & 4.6 \\
\hline WY86 & 15.8 & -- & -- & -- & -- & -- & -- & 0.29 & 0.45 & 17 & 1.89 & 490 & $<0.5$ & 0.36 & 250 & 900 & $<0.5$ & 5.1 \\
\hline WY87 & 0.9 & -- & -- & -- & -- & -- & -- & -- & -- & -- & -- & -- & -- & -- & -- & -- & -- & -- \\
\hline WY87 & 1.5 & -- & -- & -- & -- & -- & -- & -- & -- & -- & -- & -- & -- & -- & -- & -- & -- & -- \\
\hline WY87 & 12.2 & -- & -- & -- & -- & -- & -- & -- & -- & -- & -- & -- & -- & -- & -- & -- & -- & -- \\
\hline WY90 & 7.0 & 1,300 & 1,500 & 200 & 1.7 & -- & -- & 0.13 & 0.2 & 6 & 1.12 & 8,200 & 210 & 0.23 & 3,700 & 5,200 & 6.0 & 10 \\
\hline WY92 & 4.0 & 1,000 & 940 & -60 & 1.3 & -- & -- & 0.16 & 0.24 & 7.3 & 1.31 & 8,000 & 170 & 0.37 & 4,200 & 780 & 5.8 & 14 \\
\hline WY92 & 16.5 & 920 & 680 & -240 & 1.20 & -- & -- & 0.18 & 0.18 & 8.9 & 0.78 & 4,800 & 83 & 0.25 & 2,100 & 1,300 & 3.8 & 5.3 \\
\hline WY 94 & 4.3 & 1,100 & 1,100 & 0 & 1.0 & -- & -- & 0.16 & 0.3 & 10 & 1.02 & 4,900 & 110 & 0.37 & 2,400 & 1,100 & 3.4 & 6.7 \\
\hline WY100 & 3.0 & 800 & 1,000 & 200 & 710 & -- & -- & 0.35 & 0.84 & 70 & 0.84 & 4,100 & 33 & 0.50 & 3,300 & 480 & 4.3 & 4.3 \\
\hline WY100 & 7.9 & 890 & 920 & 30 & 1.1 & -- & -- & 0.220 & 0.24 & 21 & 1.42 & 6,800 & 360 & 0.33 & 2,400 & 610 & 5.4 & 8.7 \\
\hline WY100 & 16.2 & 1,200 & 1,300 & 100 & 0.86 & -- & -- & 0.063 & 0.16 & 18 & 1.15 & 11,000 & 310 & 0.56 & 5,800 & 4,300 & 6.2 & 9.2 \\
\hline
\end{tabular}

${ }^{1}$ Measured after extraction with $0.5-\mathrm{M} \mathrm{HCl}$.

${ }^{2}$ Measured after extraction with 6-M hydroxylamine (HA) in 0.5-M HCl.

${ }^{3}$ Calculated as Fe(total) minus Fe(II).

${ }^{4}$ Measured acid-volatile and chromium-reducible sulfides after extraction by method modified from Allen and others (1991; 1993).

${ }^{5}$ Measured after extraction with $10 \% \mathrm{HNO}_{3}$.

${ }^{6}$ Measured after extraction with 6-M HCl 
Table 5. Selected constituents in acid extractions and organic carbon, and analysis of bulk density and pore-water constituents of aquifer material from boreholes in the study area, Woodbury, Connecticut, 2003-04.-Continued

[Concentrations in micrograms per gram of sediment unless otherwise indicated; ID, indicates identifier; bls, below land surface; M, moles per liter; g/cc, grams per cubic centimeter; \%, percent; Fe, iron; Mn, manganese; As, arsenic; U, uranium; Al, aluminum; Ca, calcium; Cr, chromium; Cu, copper; K, potassium; $\mathrm{Mg}$, magnesium; $\mathrm{Na}$, sodium; $\mathrm{Ni}$, nickel; $\mathrm{Pb}$, lead; $\mathrm{V}$, vanadium; $\mathrm{Zn}$, zinc; $\mathrm{Cd}$, cadmium; $\mathrm{HNO}_{3}$, nitric acid; $\mathrm{HCl}$, hydrochloric acid; $\mathrm{HA}$, hydroxylamine; $\delta^{1} \mathrm{C}$, delta carbon-13; C, carbon; $\delta^{15} \mathrm{~N}$, delta nitrogen-15; --, not measured; bedrock wells shaded gray; $<$, less than]

\begin{tabular}{|c|c|c|c|c|c|c|c|c|c|c|c|c|c|c|c|c|c|}
\hline \multicolumn{8}{|c|}{ Chemical extractions } & \multicolumn{7}{|c|}{ Reston stable isotope laboratory } & \multicolumn{3}{|c|}{ Physical analyses } \\
\hline $\begin{array}{c}K \\
\text { (6-M } \\
\text { HCI) }\end{array}$ & $\begin{array}{c}\mathrm{Mg} \\
(6-\mathrm{M} \\
\mathrm{HCI})\end{array}$ & $\begin{array}{l}\mathrm{Na} \\
(6-\mathrm{M} \\
\mathrm{HCl})\end{array}$ & $\begin{array}{c}\mathrm{Ni} \\
(6-\mathrm{M} \\
\mathrm{HCl})\end{array}$ & $\begin{array}{c}\mathrm{Pb} \\
(6-\mathrm{M} \\
\mathrm{HCI})\end{array}$ & $\begin{array}{c}\text { V } \\
(6-M \\
H C l)\end{array}$ & $\begin{array}{c}\mathrm{Zn} \\
(6-M \\
\mathrm{HCl})\end{array}$ & $\begin{array}{l}\text { Cd } \\
(6-M \\
H C I)\end{array}$ & $\begin{array}{c}\delta^{13} \mathbf{C} \text { of } \\
\text { total C } \\
\text { (per mil) }\end{array}$ & $\begin{array}{c}\text { Total C } \\
\text { (weight } \\
\% \text { ) }\end{array}$ & $\begin{array}{c}\delta^{13} \mathrm{C} \text { of } \\
\text { calcite } \\
\text { C } \\
\text { (per } \\
\text { mil) }\end{array}$ & $\begin{array}{c}\text { Organic } \\
\text { C } \\
\text { (weight } \\
\% \text { ) }\end{array}$ & $\begin{array}{c}\delta^{13} \mathrm{C} \text { of } \\
\text { Organic } \\
\text { C (per } \\
\text { mil) }\end{array}$ & $\begin{array}{c}\delta^{15} \mathrm{~N} \text { of } \\
\text { total } \\
\mathrm{N} \text { (per } \\
\text { mil) }\end{array}$ & $\begin{array}{c}\text { Total N } \\
\text { (weight } \\
\% \text { ) }\end{array}$ & $\begin{array}{c}\text { Loss on } \\
\text { ignition } \\
\text { (weight } \\
\% \text { ) }\end{array}$ & $\begin{array}{l}\text { Bulk- } \\
\text { density } \\
\text { solids } \\
\text { (g/cc) }\end{array}$ & $\begin{array}{c}\text { Moisture } \\
\text { content } \\
\text { (volumetric } \\
\%)\end{array}$ \\
\hline-- & -- & -- & -- & -- & -- & -- & -- & -- & -- & -- & -- & -- & -- & -- & 4.4 & 1.3 & 0.45 \\
\hline-- & -- & -- & -- & -- & -- & -- & -- & -- & -- & -- & -- & -- & -- & -- & 0.4 & 1.6 & 0.31 \\
\hline-- & -- & -- & -- & -- & -- & -- & -- & -- & -- & -- & -- & -- & -- & -- & 3.0 & 1.6 & 0.29 \\
\hline-- & -- & -- & -- & -- & -- & -- & -- & -- & -- & -- & -- & -- & -- & -- & 0.8 & 2.0 & 0.58 \\
\hline -- & -- & -- & -- & -- & -- & -- & -- & -- & -- & -- & -- & -- & -- & -- & -- & -- & -- \\
\hline -- & -- & -- & -- & -- & -- & -- & -- & -- & -- & -- & -- & -- & -- & -- & 6.4 & 0.9 & 0.33 \\
\hline-- & -- & -- & -- & -- & -- & -- & -- & -- & -- & -- & -- & -- & -- & -- & 1.4 & 1.6 & 0.30 \\
\hline -- & -- & -- & -- & -- & -- & -- & -- & -- & -- & -- & -- & -- & -- & -- & 1 & 1.4 & 0.33 \\
\hline -- & -- & -- & -- & -- & -- & -- & -- & -- & -- & -- & -- & -- & -- & -- & 1.2 & 1.7 & 0.25 \\
\hline 550 & 1,100 & 38 & 4.8 & 3.0 & 6.2 & 7.4 & -- & -- & -- & -- & -- & -- & -- & -- & -- & -- & -- \\
\hline 720 & 1,100 & 36 & 5.2 & 3.2 & 5.5 & 7.3 & -- & -- & -- & -- & -- & -- & -- & -- & -- & -- & -- \\
\hline -- & -- & -- & -- & -- & -- & -- & -- & -- & -- & -- & -- & -- & -- & -- & 1.8 & 1.6 & 0.03 \\
\hline -- & -- & -- & -- & -- & -- & -- & -- & -- & -- & -- & -- & -- & -- & -- & 0.6 & 1.3 & 0.14 \\
\hline -- & -- & -- & -- & -- & -- & -- & -- & -- & -- & -- & -- & -- & -- & -- & 0.8 & 1.7 & 0.14 \\
\hline -- & -- & -- & -- & -- & -- & -- & -- & -- & -- & -- & -- & -- & -- & -- & 3.0 & 1.6 & 0.28 \\
\hline 630 & 1,200 & 61 & 5.4 & 3.4 & 8.5 & 7.7 & -- & -- & -- & -- & -- & -- & -- & -- & -- & -- & -- \\
\hline -- & -- & -- & -- & 1.10 & -- & -- & 0.070 & -- & -- & -- & -- & -- & -- & -- & 0.8 & -- & -- \\
\hline -- & -- & -- & -- & -- & -- & -- & -- & -- & -- & -- & -- & -- & -- & -- & -- & -- & -- \\
\hline 880 & 1,800 & -- & 11 & 2.5 & -- & 16 & 0.110 & -- & -- & -- & -- & -- & -- & -- & -- & -- & -- \\
\hline 800 & 1,900 & 85 & 7.9 & 8.30 & 7.4 & $<0.5$ & 0.020 & -- & -- & -- & -- & -- & -- & -- & -- & -- & -- \\
\hline 130 & 61 & 40 & 4.5 & 2.40 & 2.1 & $<0.5$ & 0.024 & -- & -- & -- & -- & -- & -- & -- & -- & -- & -- \\
\hline -- & -- & -- & -- & -- & -- & -- & -- & -- & -- & -- & -- & -- & -- & -- & 3 & 1.9 & 0.16 \\
\hline-- & -- & -- & -- & -- & -- & -- & -- & -- & -- & -- & -- & -- & -- & -- & 1.8 & 1.6 & 0.16 \\
\hline -- & -- & -- & -- & -- & -- & -- & -- & -12.7 & 0.4 & -8.52 & 0.08 & -26.9 & -- & 0.01 & -- & -- & -- \\
\hline 850 & 2,400 & 95 & 6.8 & 1.40 & 16 & 13 & 0.026 & -11.1 & 0.17 & -7.34 & 0.06 & -24.8 & -- & 0.01 & -- & -- & -- \\
\hline 1,200 & 1,700 & 45 & 8.4 & 1.20 & 11 & 17 & 0.017 & -27.9 & 2.05 & -- & 2.7 & -27.9 & 2.83 & 0.11 & -- & -- & -- \\
\hline 660 & 1,000 & 26 & 6.4 & 0.98 & 7.9 & $<0.5$ & 0.014 & -25.6 & 0.15 & -- & 0.15 & -26.3 & -- & 0.01 & -- & -- & -- \\
\hline 590 & 920 & 27 & 7.1 & 1.20 & 10.1 & 8.4 & 17 & -23.5 & 0.06 & -- & 0.06 & -- & -- & 0.01 & -- & -- & -- \\
\hline 160 & 1,200 & 94 & 7.5 & 1.10 & 14 & 18 & 0.07 & -18.9 & 0.05 & -- & 0.04 & -22.8 & -- & 0.01 & -- & -- & -- \\
\hline 490 & 940 & 32 & 8.6 & 1.60 & 9.3 & 9.0 & 0.027 & -23.3 & 0.06 & -- & 0.07 & -24 & -- & 0.01 & -- & -- & -- \\
\hline 1,700 & 4,000 & 130 & 11 & 1.50 & 31 & 32 & 0.028 & -22.8 & 0.06 & -- & 0.05 & -23.9 & -- & 0.01 & -- & -- & -- \\
\hline
\end{tabular}


The upper part of the borehole below the thin glacial till is a highly weathered, gray-green unconsolidated material (saprolite) that grades to a massive fine-grained basalt containing abundant amygdule vesicles filled with secondary minerals, similar to those described by Garabedian and others (1996) that contained calcite, quartz, prehnite, pumpellyite, apophyllite, and other minerals. Most of the these vesicles are filled and did not yield water, but one or two fractures at the 12.2- to $12.5-\mathrm{m}$ depth that are tilted eastward about 15 degrees yielded about $0.8 \mathrm{~L} / \mathrm{min}$. The fractures are consistent with the strata. Below this zone is massive basalt with no fractures evident; it may represent the lower member of the Orenaug Basalt. To the southeast, the basalt is brecciated and highly altered as a result of its close proximity to the eastern border fault, which parallels and probably underlies South Brook (Burton and others, 2005). The basalt contains abundant secondary silica, chlorite, and calcite. Two former $\mathrm{Cu}$ prospects are located to the west of WY86 and across South Brook. Whole-rock analysis of a sample from 23-m depth showed relatively low concentrations of As at $1.7 \mu \mathrm{g} / \mathrm{g}, \mathrm{U}$ at less than the detection limit, and $\mathrm{Cu}$ at $50 \mu \mathrm{g} / \mathrm{g}$. A sample collected from the lower member of the Orenaug Basalt by Burton and others (2005) had an As concentration of $5.1 \mu \mathrm{g} / \mathrm{g}$.

\section{Fission-Track Radiography}

Most sediment grains in core samples consisted of quartz and feldspar and did not show much evidence of $U$; however, some reddish Fe-oxide grains appeared to have much higher U concentrations, which were estimated using fission-track radiography. Fission-track maps were produced from epoxy-mount thin sections of core samples to determine the distribution of $U$. A fission-track map of sediments from the 17-m depth at WY75 (fig. 9), for example, shows the $\mathrm{U}$ distribution in ferric hydroxide coatings on sediment grains. These sediments may be derived from Mesozoic rocks, such as the Cass Formation, and are similar to sediments near WY83. Estimated $\mathrm{U}$ content is on the order of 10 to $100 \mu \mathrm{g} / \mathrm{g}$, based on fission-track density (Brown and Zielinski, 2004). The overall abundance of such oxides is low, and their fractional contribution of $\mathrm{U}$ to the total $\mathrm{U}$ inventory in the rock is probably less than a few percent, but emanation of ${ }^{222} \mathrm{Rn}$ from such sites could account for a large fraction of total ${ }^{222} \mathrm{Rn}$ emanation. The distribution of $\mathrm{U}$ in the aquifer material implies the co-occurrence of $\mathrm{U}$ progeny such as Ra. ${ }^{22} \mathrm{Rn}$, which is derived from the decay of ${ }^{226} \mathrm{Ra}$, was present at high activities in the glacial aquifer and crystalline rock in upland areas, as discussed later in the "Naturally Occurring Constituents of Concern" section.

\section{Carbon Content}

The organic-C content of core samples from the Pomperaug aquifer system generally was low, although sediments at some sites had concentrations greater than 3 percent by weight (table 5). Higher organic-C content generally is consistent with groundwater samples that contain relatively high, natural DOC concentrations (Brown and others, 2006). Organic-matter content also was measured in shallow, unsaturated-zone deposits by loss-on-ignition; these values range from about 0.4 percent to 4.4 percent by weight and reflect the high organic content typical of the soil zone (table 5). Several exceptions to this vertical distribution of organic C include the WY92 well site, where organic-rich
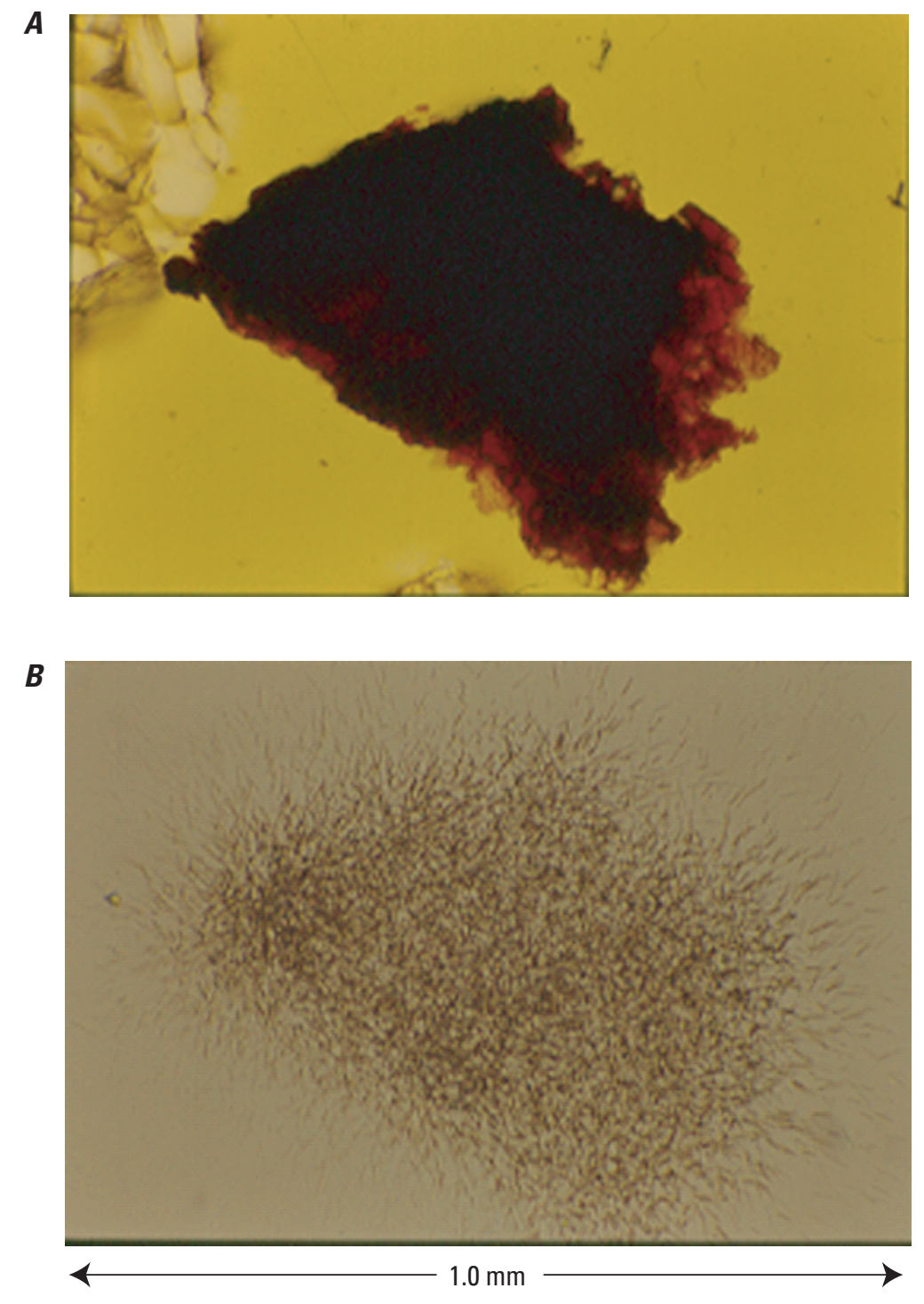

Figure 9. Optical microscope images of a sample of glacial deposits from 17 meters depth from land surface at borehole WY75, showing (A) an iron-oxide grain, and $(B)$ fission tracks recorded after irradiation with uranium-235 on the same sample, Woodbury, Connecticut. 
sediment was observed at the water table from 3.6 to $4.3 \mathrm{~m}$ and reflects buried wetland deposits. Similarly, a core sample from a depth of 2.7 to $3.4 \mathrm{~m}$ below land surface at WY100 had a high observed organic-matter content, but that is not reflected in the subsample analyzed (table 5). At WY83, sediments in a blackish red, 6-cm layer in the core from the 6.1 to $6.7 \mathrm{~m}$ depth, appeared to be dark and organic rich, and a subsample from this depth interval had a weight loss-onignition result of 0.8 percent (table 5). Groundwater samples from the WY83 well screen adjacent to this depth were high in DOC, and redox conditions typically were anoxic; these results reflect the presence of source material from the Cass Formation, as discussed in the section "Surficial Geology." A mineralized fault exposed at a quarry about $1.9 \mathrm{~km}$ to the north of WY83 contains bitumen, as well as quartz, calcite, stilbite, and other secondary minerals (Burton and others, 2005). The Shuttle Meadow Formation, the equivalent unit to the Cass Formation in the Hartford Basin, contains a normal distribution of saturated hydrocarbons (Kotra and others, 1988; Dickneider and others, 1996), and similar units of the Newark Supergroup in eastern North American rift basins have some hydrocarbon potential (Ziegler, 1983).

The $\delta^{13} \mathrm{C}$ values for total $\mathrm{C}$ in core samples ranged from -28 to -11 per mil. $\delta^{13} \mathrm{C}$ values of organic $\mathrm{C}$ ranged from -28 to -23 per mil; these values are similar to those in the Newark and Culpeper Basins (-27 to 20.7) and may indicate lacustrine-algal deposits (Spiker, 1985). In the Hartford Basin, caliche calcites in fluvial mudstones have $\delta^{13} \mathrm{C}$ isotopic compositions ranging from -7.3 to -3.8 per mil, indicating that paleosol processes occurred during warm and dry climatic conditions in Late Triassic time (Suchecki and others, 1988). Only two of the eight samples that were submitted contained enough calcite for analysis of $\delta^{13} \mathrm{C}$ : a till from WY90 and a mineralized basalt fracture at WY87 had values of -7.34 and -8.52 , respectively.

\section{Adsorption Reactions}

Experimental data for adsorption batch-reactor experiments were modeled using PHREEQC (Parkhurst and Appelo, 1999) with the generalized two-layer surface complexation model of Dzombak and Morel (1990) to determine adsorption reactions. Solution composition and adsorption site density were included as known quantities. Equilibrium constants for the surface-complexation reactions used to simulate $\mathrm{As}(\mathrm{V})$ and $\mathrm{U}(\mathrm{VI})$ adsorption were adjusted to give the best fit to experimental results for WY100 (table 6). These equilibrium constants then were used to simulate the experimental results for the remaining sediment samples.

The results of column experiments indicate that substantial adsorption occurred for the four samples of the glacial stratified deposits (WY83, 92, 94, and 100), and much less adsorption occurred for the glacial till (WY90). Isotherms for $\mathrm{As}(\mathrm{V})$ adsorption by sediments are plotted in figure 10A. Surface-complexation equilibrium constants were adjusted to give the best fit to data from the experiment with WY100 sediments (table 6B). These constants then were used to model $\mathrm{As}(\mathrm{V})$ adsorption by the other sediment samples. It was assumed that all adsorption occurred at weak surface sites, characteristic of anion adsorption (Dzombak and Morel, 1990). The model accurately simulated adsorption by aquifer sediments from WY83, WY92, and WY94; however, the model predicted more adsorption by sediments from WY90 than was observed. Two possible explanations for the overpredicted adsorption are that core sediment from WY90 (1) represents glacial till and may have a different assemblage of sorption sites with respect to $\mathrm{As}(\mathrm{V})$ than the four samples collected from glacial stratified deposits, and (2) was downgradient from a septic-tank drainfield and the sediment may have been exposed to groundwater with solutes that strongly sorbed to the sediment, thereby blocking $\mathrm{As}(\mathrm{V})$ adsorption. The concentration of $\mathrm{As}(\mathrm{V})$ on surface sites measured by $\mathrm{H}^{+}$titration for WY90 was 160 micromoles per liter $(\mu \mathrm{M} / \mathrm{L})$, although the surfacesite $\mathrm{As}(\mathrm{V})$ concentration that gave the best match to the experimental data was only $26 \mu \mathrm{M} / \mathrm{L}$ (fig. 10A). This indicates the presence of a solute that blocked $\mathrm{As}(\mathrm{V})$ adsorption but not $\mathrm{H}^{+}$or an assemblage of adsorption sites that differed in response to $\mathrm{As}(\mathrm{V})$ and $\mathrm{H}^{+}$than those on the four glacial stratified sediment samples. Carbonate minerals were apparent in the WY90 sediment, and although the $\mathrm{H}^{+}$titration was adjusted to take this into account, it is possible there was still some carbonate associated with surface sites that blocked $\mathrm{As}(\mathrm{V})$ adsorption.

U(VI) also was strongly adsorbed by the four samples of glacial stratified deposits (fig. 10B). The same modeling technique used for $\mathrm{As}(\mathrm{V})$ was applied to $\mathrm{U}(\mathrm{VI})$ adsorption with similar results. Because uncomplexed U(VI) occurs as the $\mathrm{UO}_{2}^{+2}$ cation, strong sorption sites were included (table 6). The concentration of strong sorption sites was estimated to be 2.5 percent of the weak-site concentration (Dzombak and Morel, 1990). In the presence of carbonate ions, the dominant $\mathrm{U}(\mathrm{VI})$ species in solution are $\mathrm{UO}_{2}\left(\mathrm{CO}_{3}\right)_{3}{ }_{3}{ }^{4}$ and $\mathrm{UO}_{2}\left(\mathrm{CO}_{3}\right)_{2}{ }^{2-}$, and these species are adsorbed by the weak sites.

Surface-complexation equilibrium constants (table 6B) fit to the WY100 isotherm also simulated U(VI) adsorption by the other glacial-stratified deposit samples reasonably well, but overpredicted adsorption by sediments from WY90. Even the lower site concentration of $26 \mu \mathrm{M} / \mathrm{L}$ used for As(V) resulted in overpredicted $\mathrm{U}(\mathrm{VI})$ adsorption. In fact, there was a net release of U(VI) to solution in the experiment with WY90 sediments. It is possible some $\mathrm{U}(\mathrm{VI})$ coprecipitated with the carbonate minerals in the sediment and was released during the adsorption experiment.

\section{Groundwater Chemistry}

Water-chemistry constituents measured in the glacial aquifer system include major and trace constituents, radionuclides, stable isotopes, and dissolved gases, VOCs and pesticides, and age tracers. The groundwater chemistry 
Table 6. Results of adsorption experiments on aquifer material sampled in the study area, including $(A)$ the $\mathrm{pH}$, bicarbonate, and surface sorption site concentrations for arsenic (V) and uranium (VI), and (B) equilibrium constants for PHREEOC model of adsorption using experimental data.

[ID, indicates identifier; bls, below land surface; mmol/L, millimoles per liter; mg/L, milligrams per liter; As, arsenic; U, uranium; K, equilibrium constant; Site_wOH, weak sorption sites; Site_sOH, strong sorption sites]

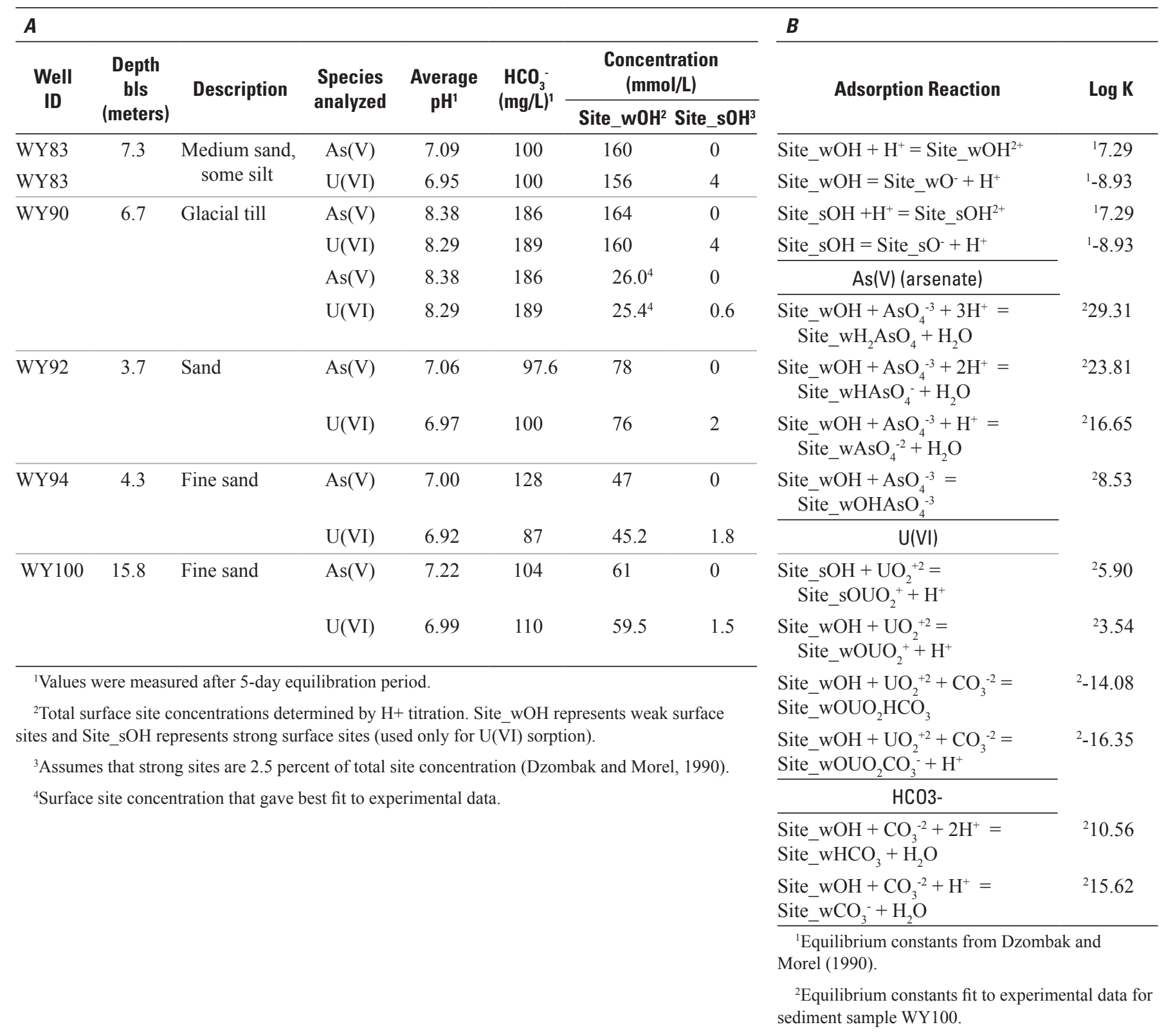



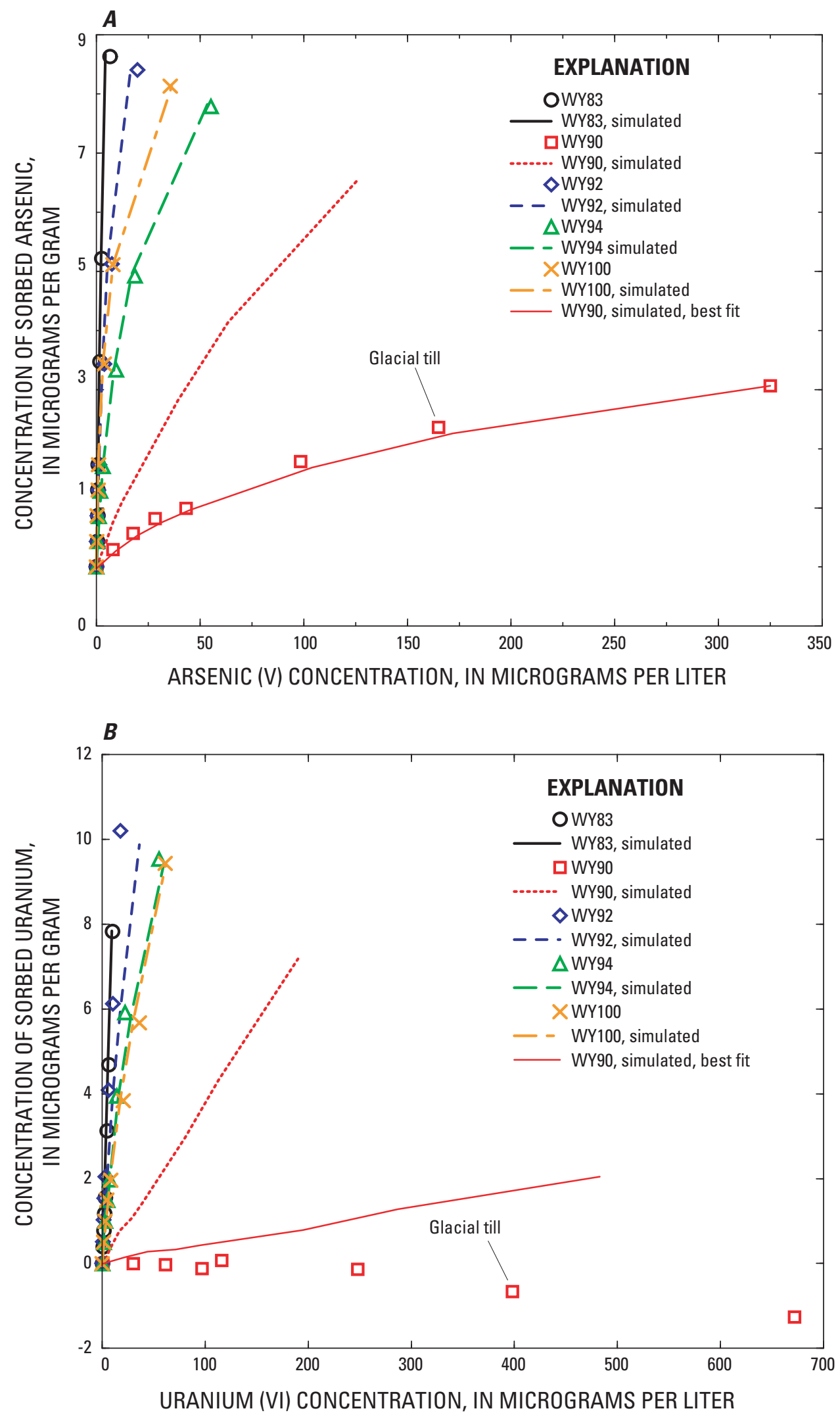

Figure 10. Concentrations of $(A)$ arsenic $(V)$ in water as a function of arsenic sorbed, and $(B)$ uranium $(\mathrm{VI})$ in water as a function of uranium sorbed, based on column experiments of core sediments from WY83 (7.3 meters depth below land surface), WY90 (6.7 meters depth below land surface), WY92 (3.7 meters depth below land surface), WY94 (4.3 meters depth below land surface), and WY100 (4.8 meters depth below land surface), and simulated sorption for these samples using PHREEOC (Parkhurst and Appelo, 1993). 
of this glacial aquifer system is primarily affected by weathering of aquifer material and associated naturally occurring constituents of concern, and by anthropogenic sources, including road salt, leachate from septic-tank drainfields (or septic-system leachate), leaking underground storage tanks, chemical spills, and stormwater runoff from roads and parking lots to dry wells or losing streams. Several tools were used to help distinguish anthropogenic sources or pathways from natural ones, including Piper diagrams, scatter plots, $\mathrm{Cl}: \mathrm{Br}$ ratio plots, stable isotopes, dissolved gases, and groundwater age tracers. Differences in chemical signatures among the parts of the aquifer system are used to improve the understanding of groundwater-flow patterns and pathways, and to test hypotheses for processes that affect water quality in well PSW-1.

\section{Major Elements and Nutrients}

Groundwater in the glacial aquifer within the study area is generally a $\mathrm{Ca}, \mathrm{Na}, \mathrm{Mg}-\left(\mathrm{HCO}_{3}\right)_{0-2}$ water and reflects the weathering from natural sources and constituents derived from anthropogenic sources or activities (table 7). Groundwater samples had a median specific conductance of $278 \mu \mathrm{S} / \mathrm{cm}$ but ranged from $104 \mu \mathrm{S} / \mathrm{cm}$ near a losing stream to $1,530 \mu \mathrm{S} / \mathrm{cm}$ near a septic-tank drainfield. Glacial stratified deposits contribute most of the groundwater to PSW-1; the water was mostly oxic, had a low-to-neutral $\mathrm{pH}$ range (5.6 to 6.9), and was undersaturated with respect to calcite (table 7). However, the chemistry of groundwater in the glacial aquifer is affected by groundwater in underlying and adjacent till and bedrock that can impart higher $\mathrm{pH}$ and dissolved $\mathrm{CO}_{2}$, reducing conditions, and higher specific conductance (table 7; fig. 11). Concentrations of $\mathrm{SO}_{4}^{2-}$ and some trace constituents (table 8) can be high in groundwater from fractured bedrock that underlies the valley bottom and can affect groundwater chemistry in the glacial aquifer.

Shallow groundwater (greater than $3 \mathrm{~m}$ above bedrock) has a distinctly different chemistry than deep groundwater (within $3 \mathrm{~m}$ of bedrock or deeper) in glacial stratified deposits, glacial till, and bedrock. Shallow groundwater has higher specific conductance (and, therefore, dissolved solids) than deep water and appears to be affected by septic-system leachate, application of road salt, and other anthropogenic sources (fig. 11). On the basis of a one-factor ANOVA, the $\mathrm{pH}$ was significantly higher in water samples from wells finished in bedrock and glacial deposits adjacent to bedrock than it was in shallow and intermediate (herein referred to as "shallow") parts of the glacial aquifer (fig. 12A). Also, the $\mathrm{HCO}_{3}$ concentration was significantly higher in samples from wells finished in bedrock and glacial deposits adjacent to bedrock, with the exception of well WY106. The locally calcareous composition of mineral-filled basalt fractures and gneiss, schist, and pegmatite (tables 3 and 5) likely caused the higher $\mathrm{pH}$ of groundwater in bedrock and adjacent deep glacial deposits. The $\mathrm{pH}$ is an important factor in the occurrence and movement of natural contaminants, such as As, $\mathrm{U}$, and other trace elements. The aquifer system can be categorized by depth and (or) aquifer material into zones of distinct ranges of $\mathrm{pH}$ (table 7). The $\mathrm{pH}$ differences probably can be attributed to anthropogenic sources, groundwater age, and water-rock interaction, particularly in areas where the aquifer matrix contains calcite or dolomite, such as in basalt fractures. The $\mathrm{pH}$ zones are (1A) shallow depths, where the $\mathrm{pH}$ of water typically is 5.3 to 6.4 , and (1B) deep glacial depths within 3 meters of bedrock, where the $\mathrm{pH}$ of water typically is in the range of 6.4 to 7.5 (table 7). Groundwater samples from wells screened in compact till typically have higher $\mathrm{pH}$ of the deep glacial zone 1B, including shallow wells such as WY89. Groundwater in fractured bedrock can be divided into (2A) the upper $100 \mathrm{ft}$ of bedrock, where $\mathrm{pH}$ ranges from 6.9 to 8.3 , and (2B) deep bedrock, where the $\mathrm{pH}$ is about 9 .

Major-ion concentrations in groundwater samples from wells screened in the lower part of the glacial stratified deposits, or in glacial till, generally reflect those of underlying bedrock, as observed on a Piper diagram (fig. 13). The Piper diagram (Hem, 1992) is used to show the clustering of samples by water type, and the effects of aquifer weathering and anthropogenic activities on major ion concentrations; samples are represented by the percentages of total cations and total anions, plotted on separate trilinear plots, then projected onto a central diamond (Hem, 1992). The ion percentages for most deep glacial aquifer wells plotted close together, whereas those for the shallow depth wells of the same cluster are relatively scattered on the diagram. Groundwater samples from wells in deep glacial deposits, till, and bedrock show greater percentages of $\mathrm{Ca}$ and $\mathrm{HCO}_{3}^{-}$(fig. 13) and reflect weathering of calcite in bedrock. The deep glacial well WY82 is an exception to this grouping and may reflect a large downward gradient at this site, coupled with the location at an intersection of roads and, therefore, vulnerability to roadsalt runoff. Concentrations of $\mathrm{HCO}_{3}^{-}$and $\mathrm{SiO}_{2}$, which also is a product of weathering, were plotted to help determine the relative extent of aquifer weathering (fig. 14A).

The extent of aquifer weathering also can be approximated by the groundwater residence time. The particle-tracking program MODPATH was used to simulate groundwater residence time, which in turn was used to relate natural and anthropogenic factors to water quality (table 9; Starn and Brown, 2007). Groundwater from WY83 appears to be young and has a short simulated flow path $(<1$ year), but the flow path probably moves through a greater percentage of silt and clay minerals and carbonate minerals derived from the Cass Formation that are more easily weathered than other well flow paths, as indicated by the relatively high dissolved silica and saturation indices for calcite and dolomite (table 7). Glacial till also contains a greater proportion of clay, calcite, and other reactive minerals and, therefore, contains higher concentrations of dissolved silica and $\mathrm{HCO}_{3}^{-}$(table 7).

Bedrock well WY87, in the Mesozoic basalt, had ion percentages similar to those of both wells (WY86 and WY97) in the Paleozoic rock (fig. 13) and may reflect similar rock chemistry, or the close proximity of WY87 to the contact 


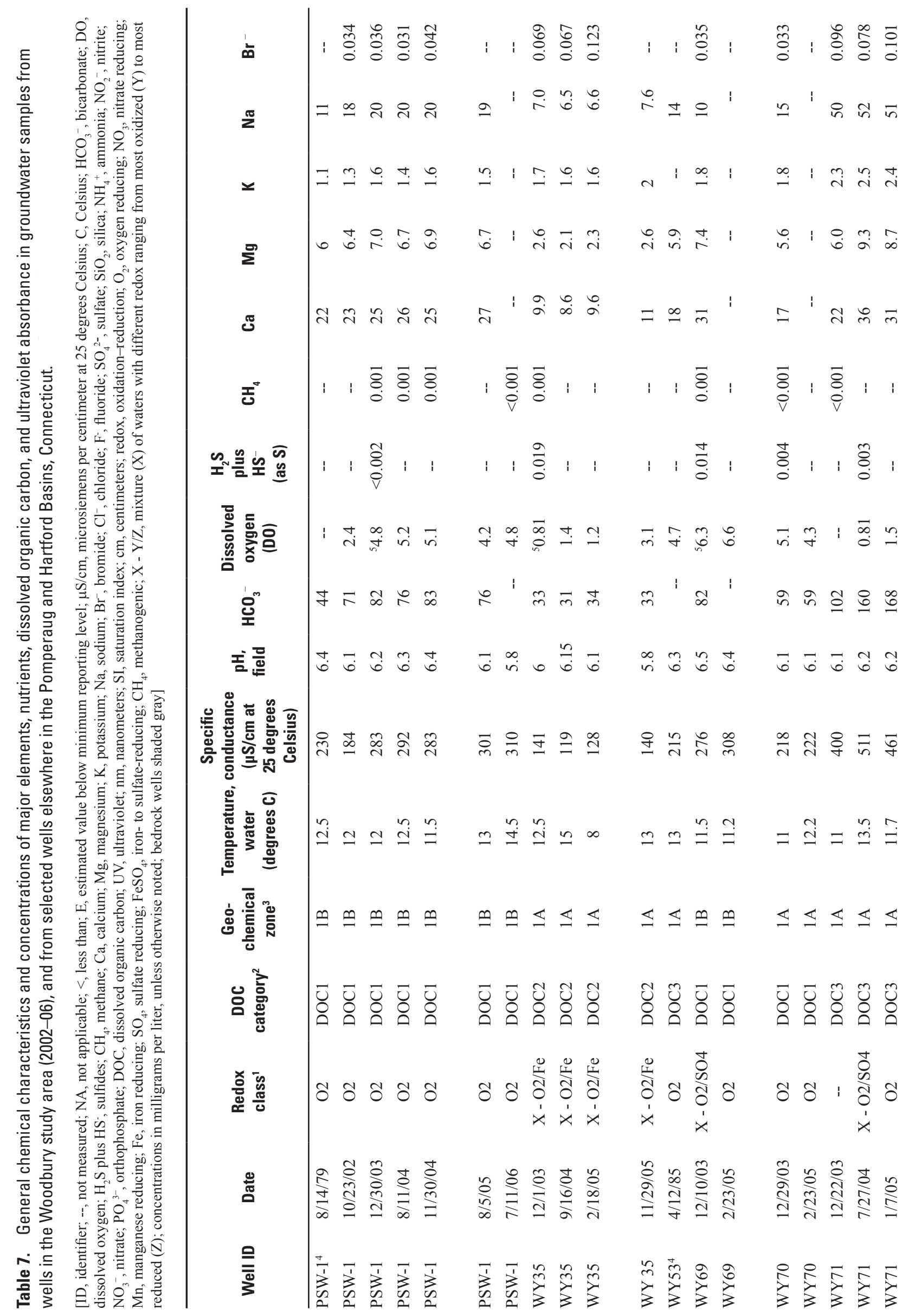




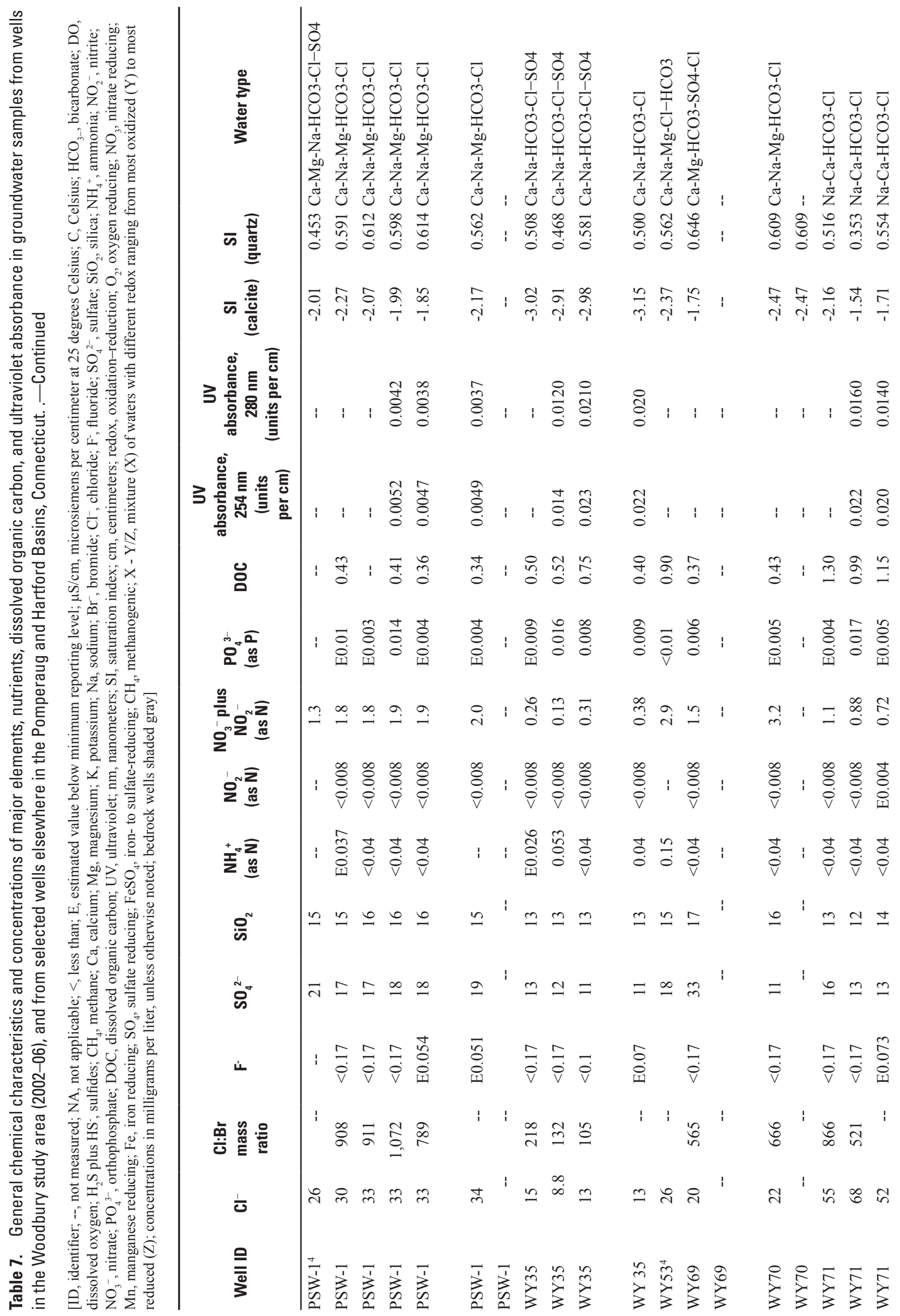




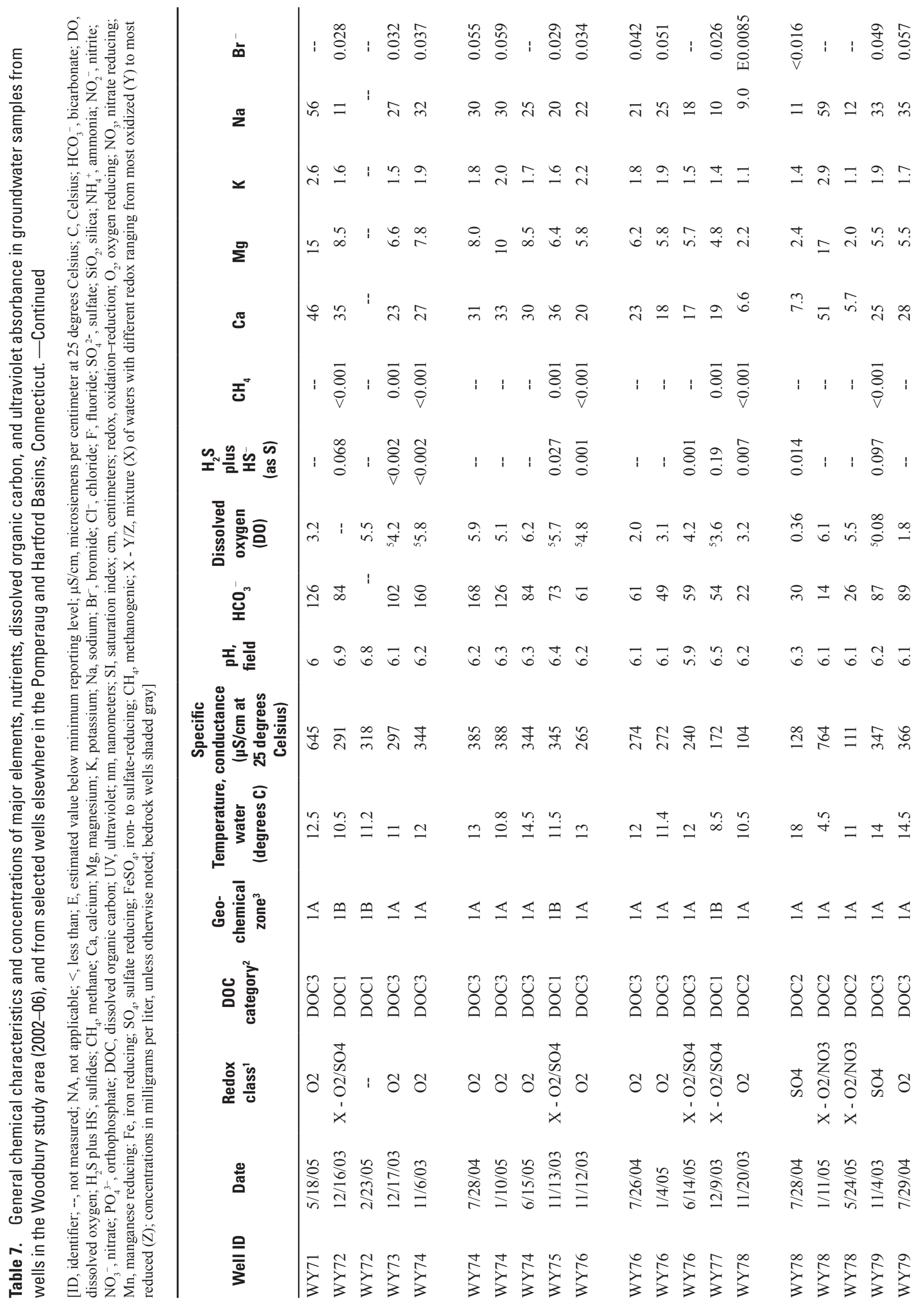




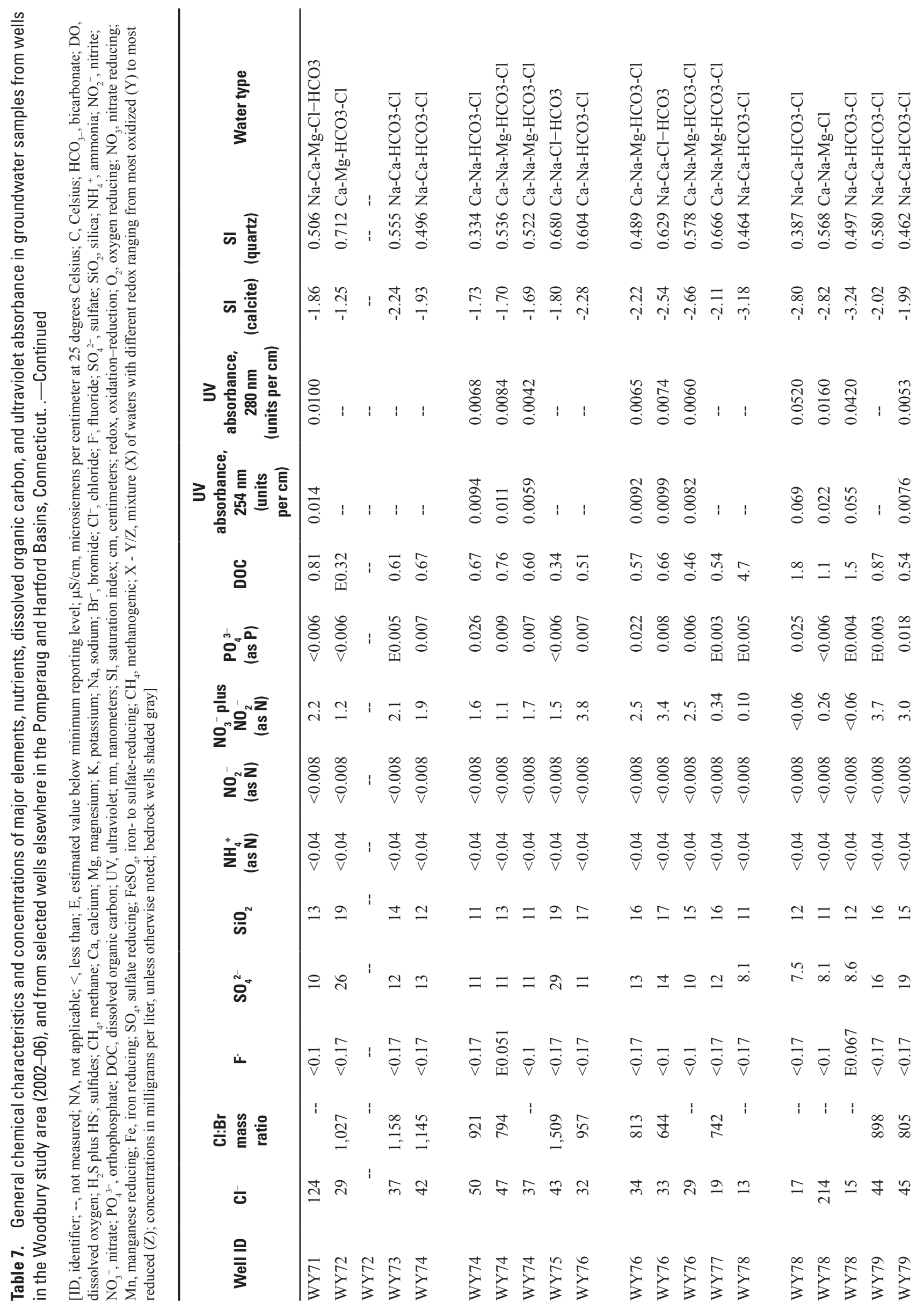




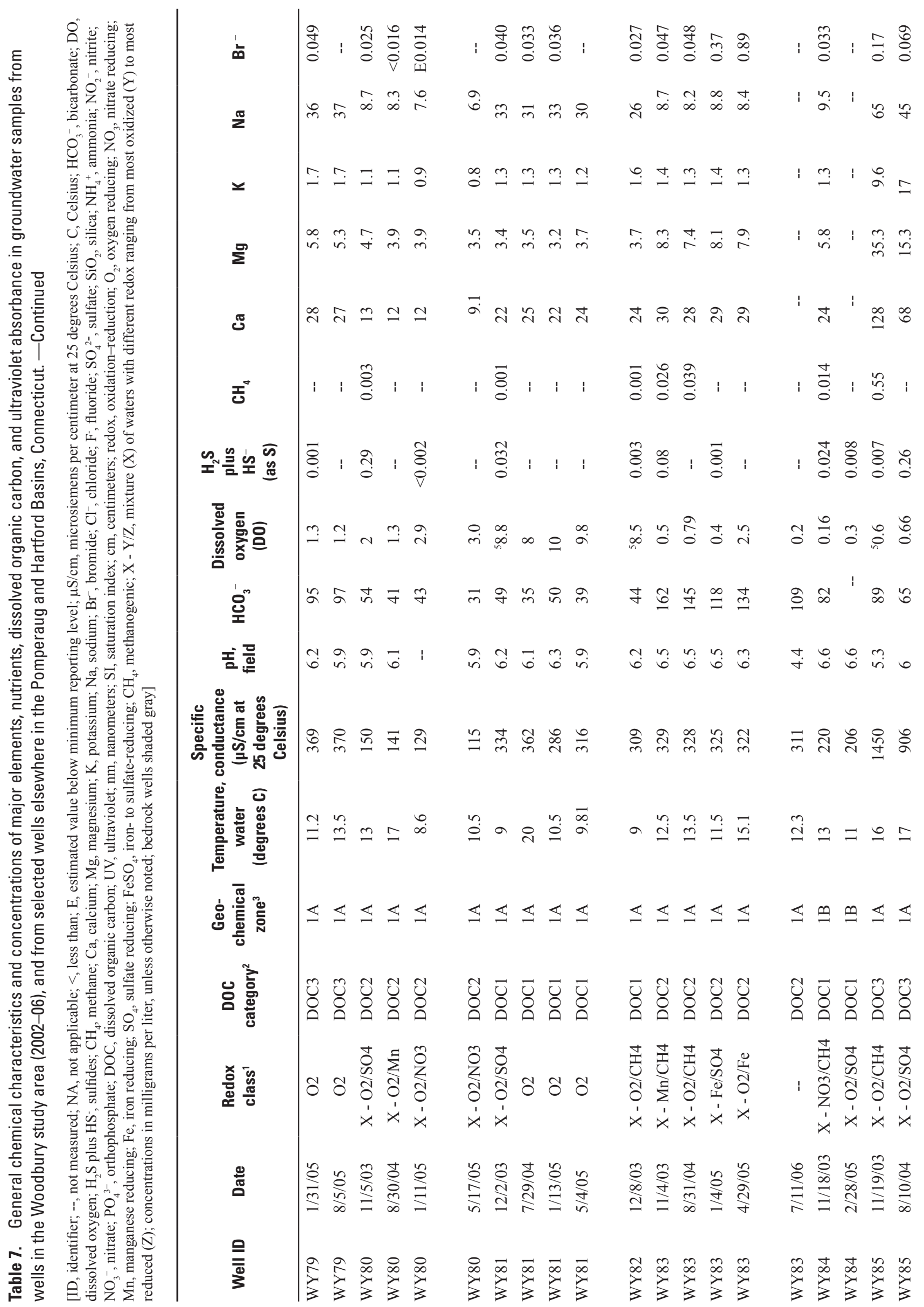




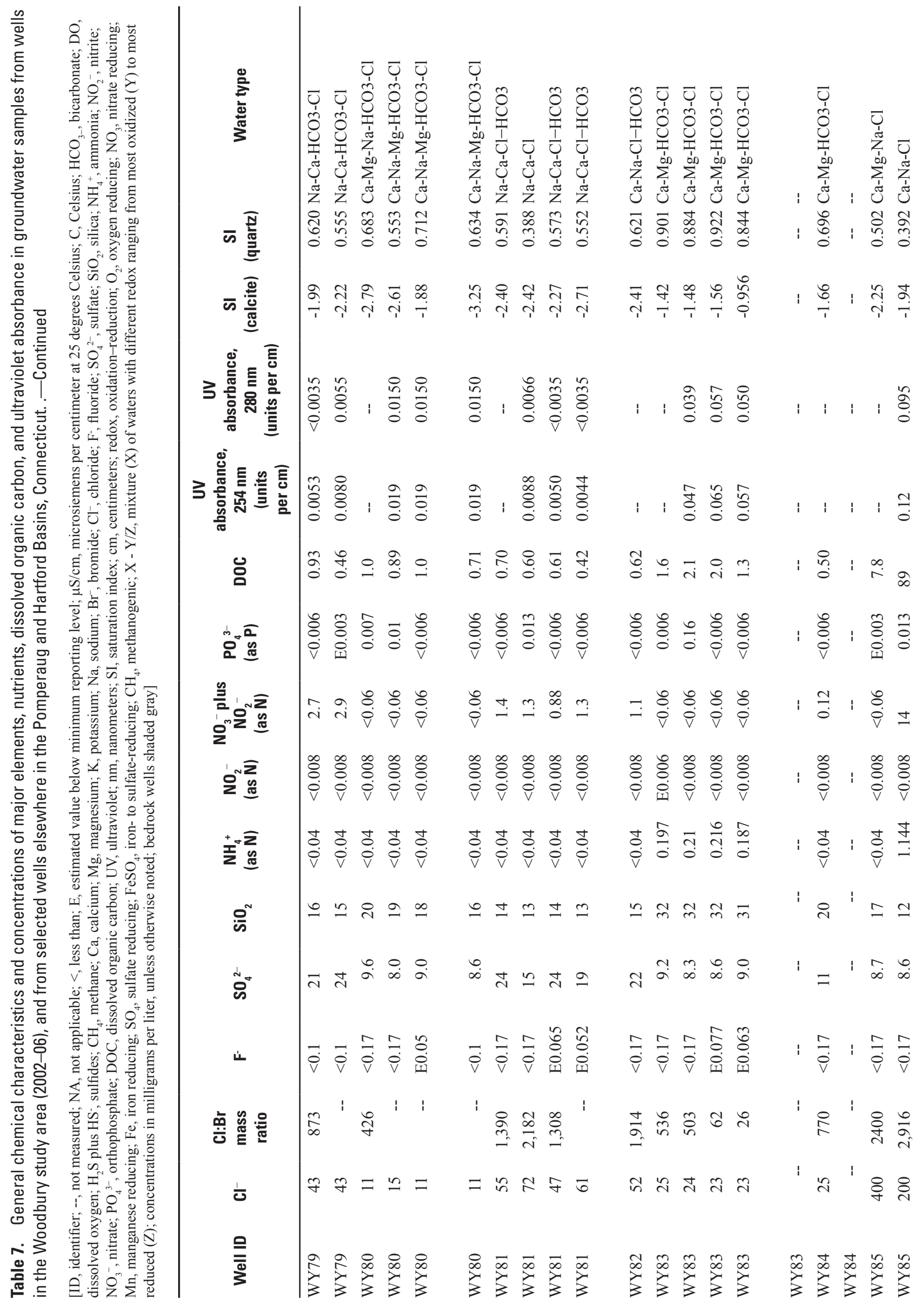




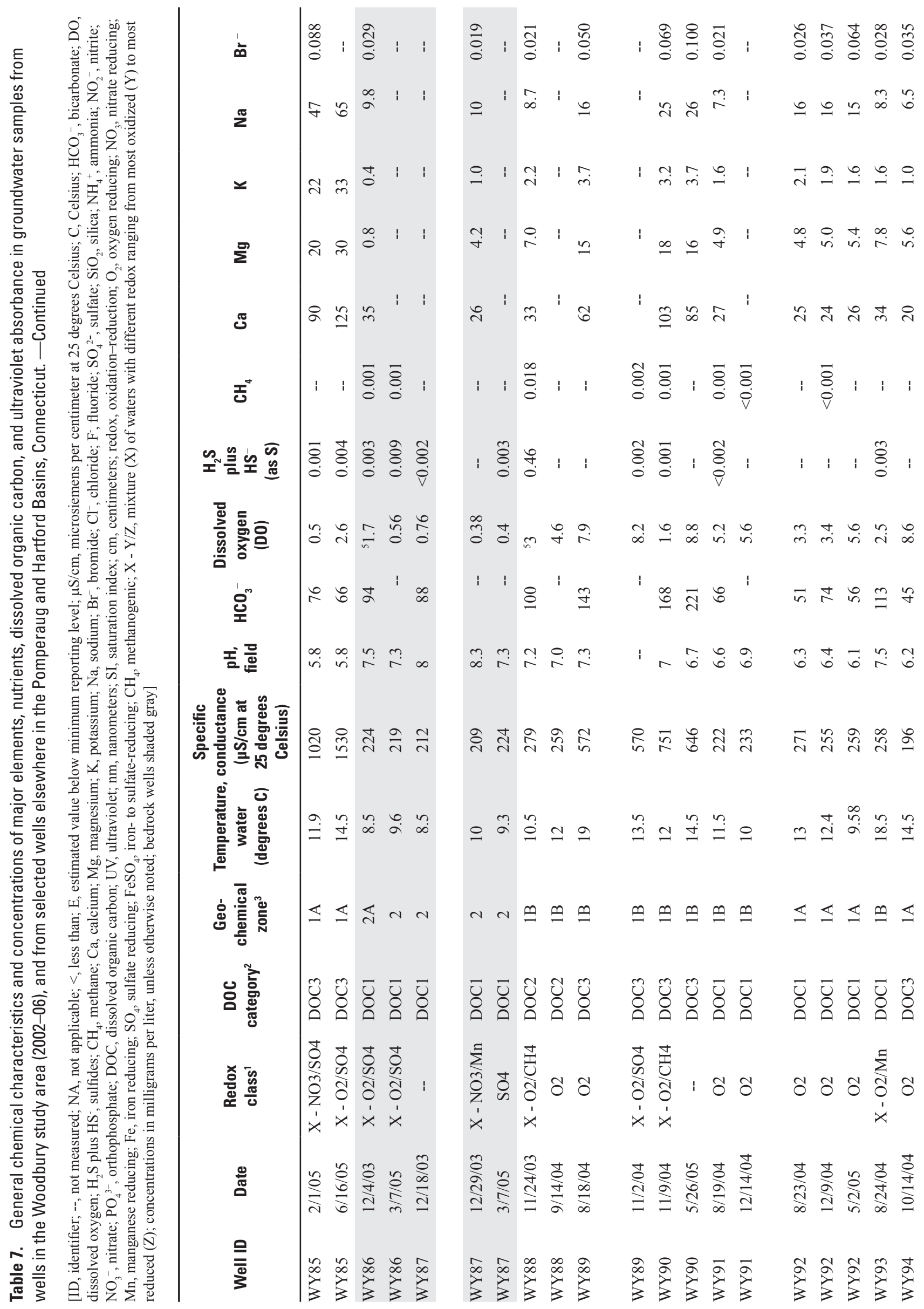




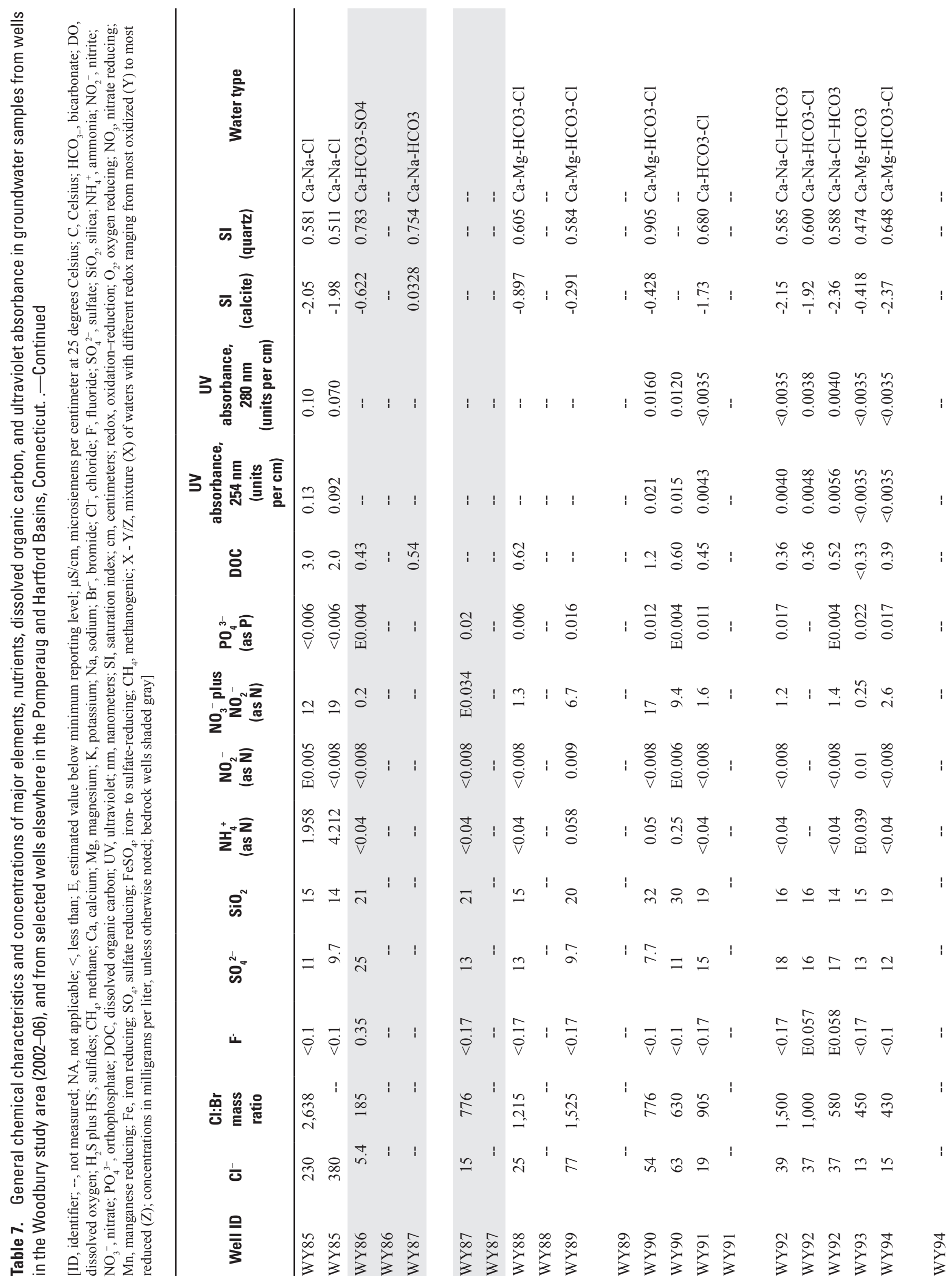




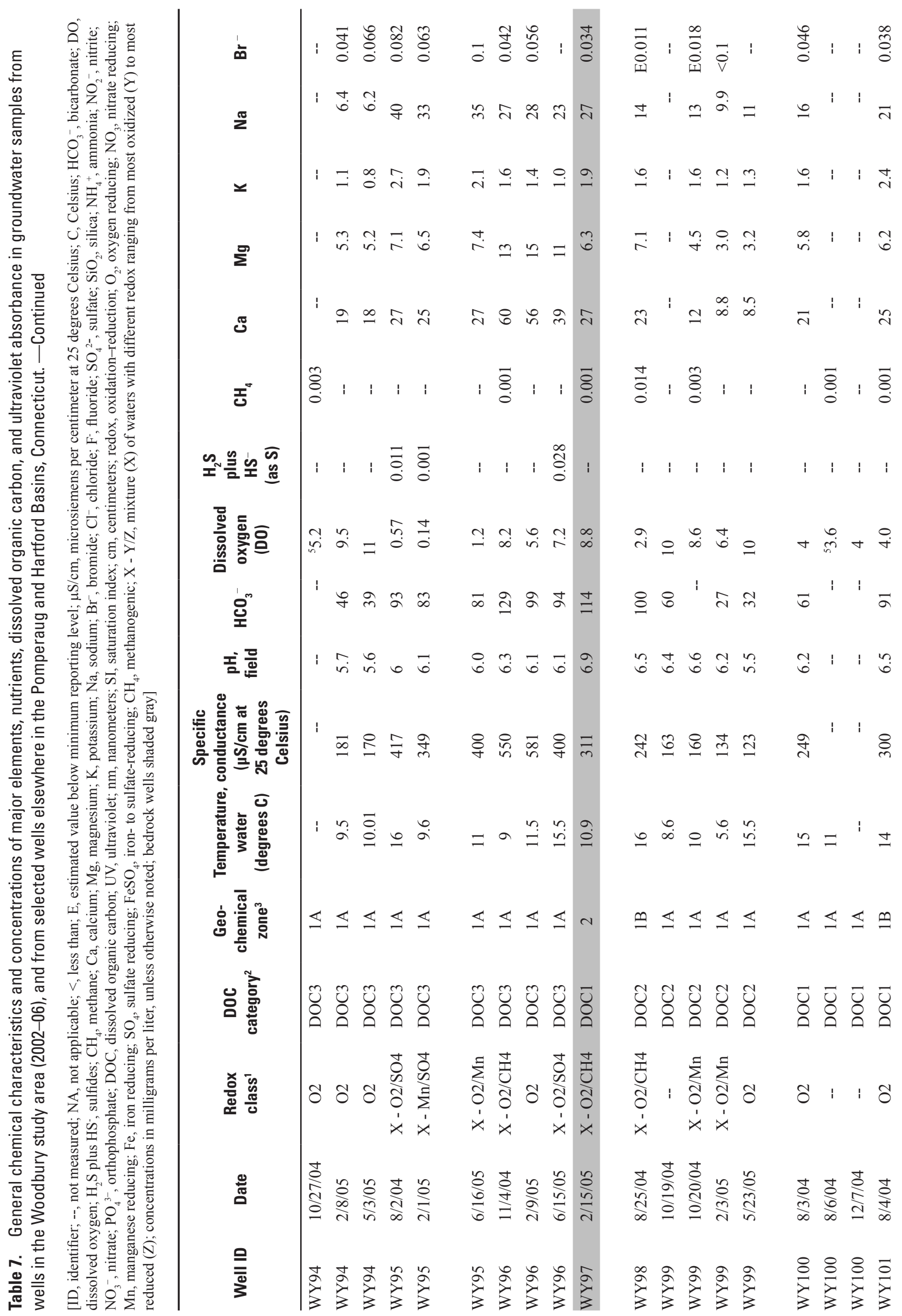




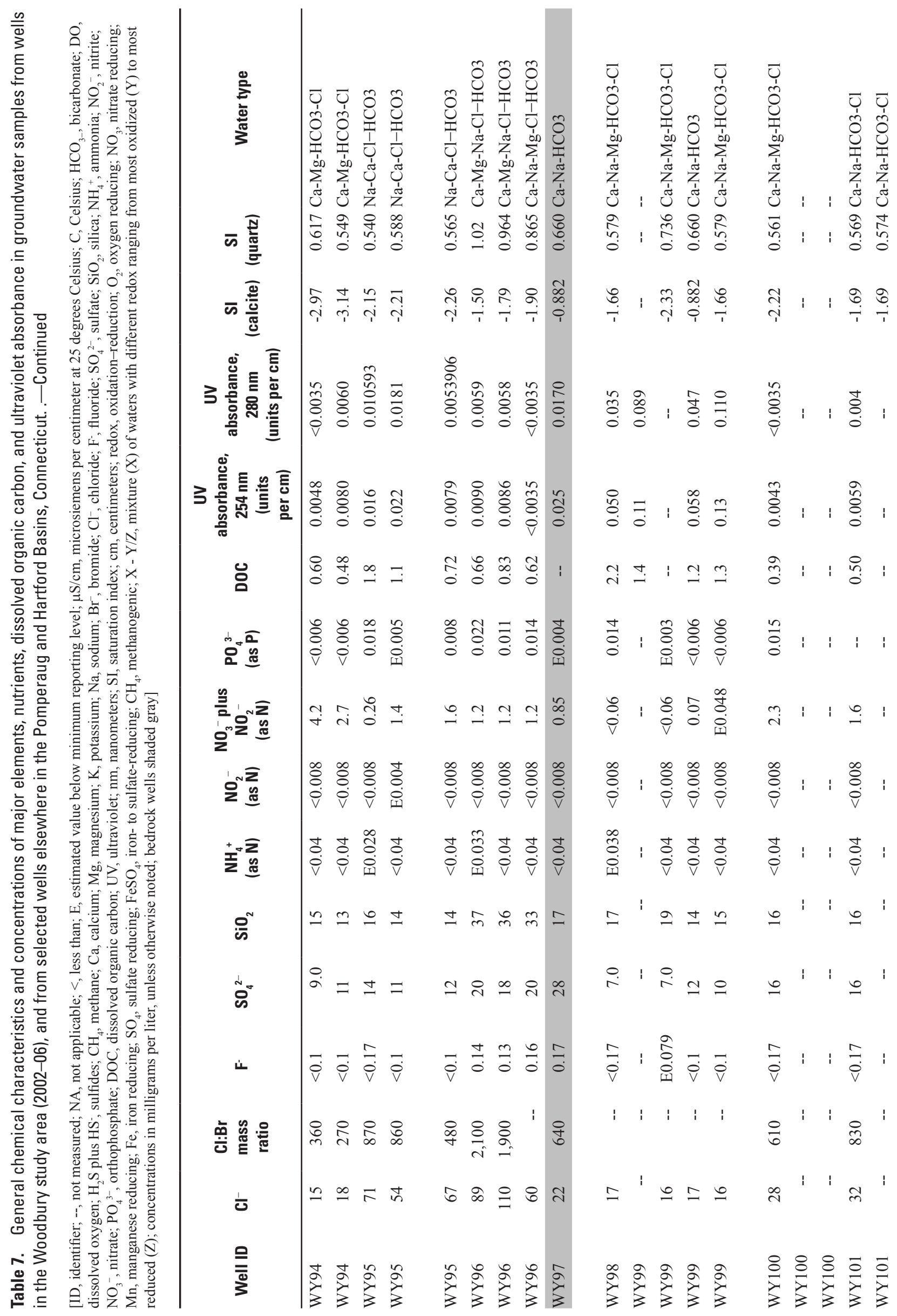




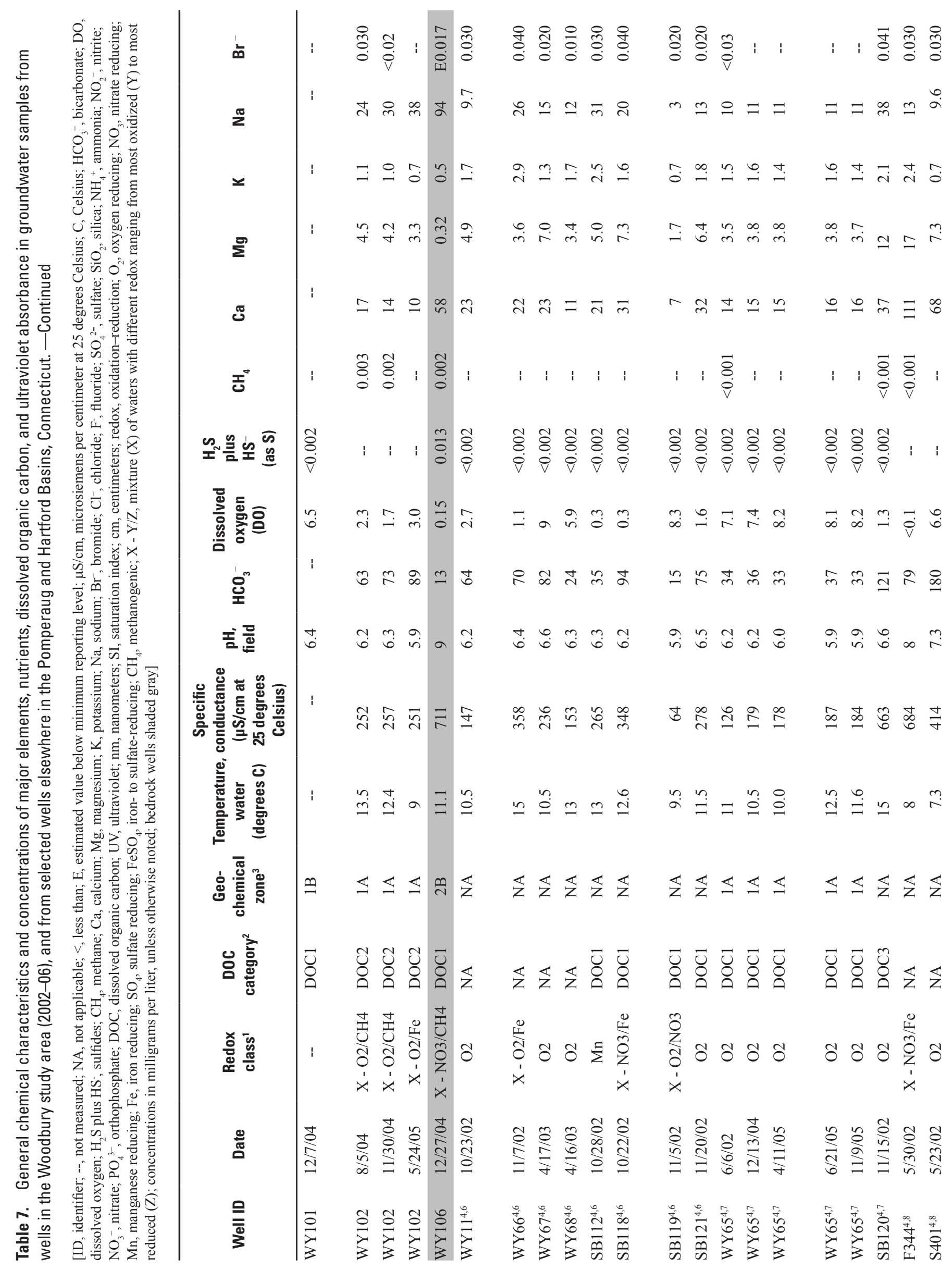




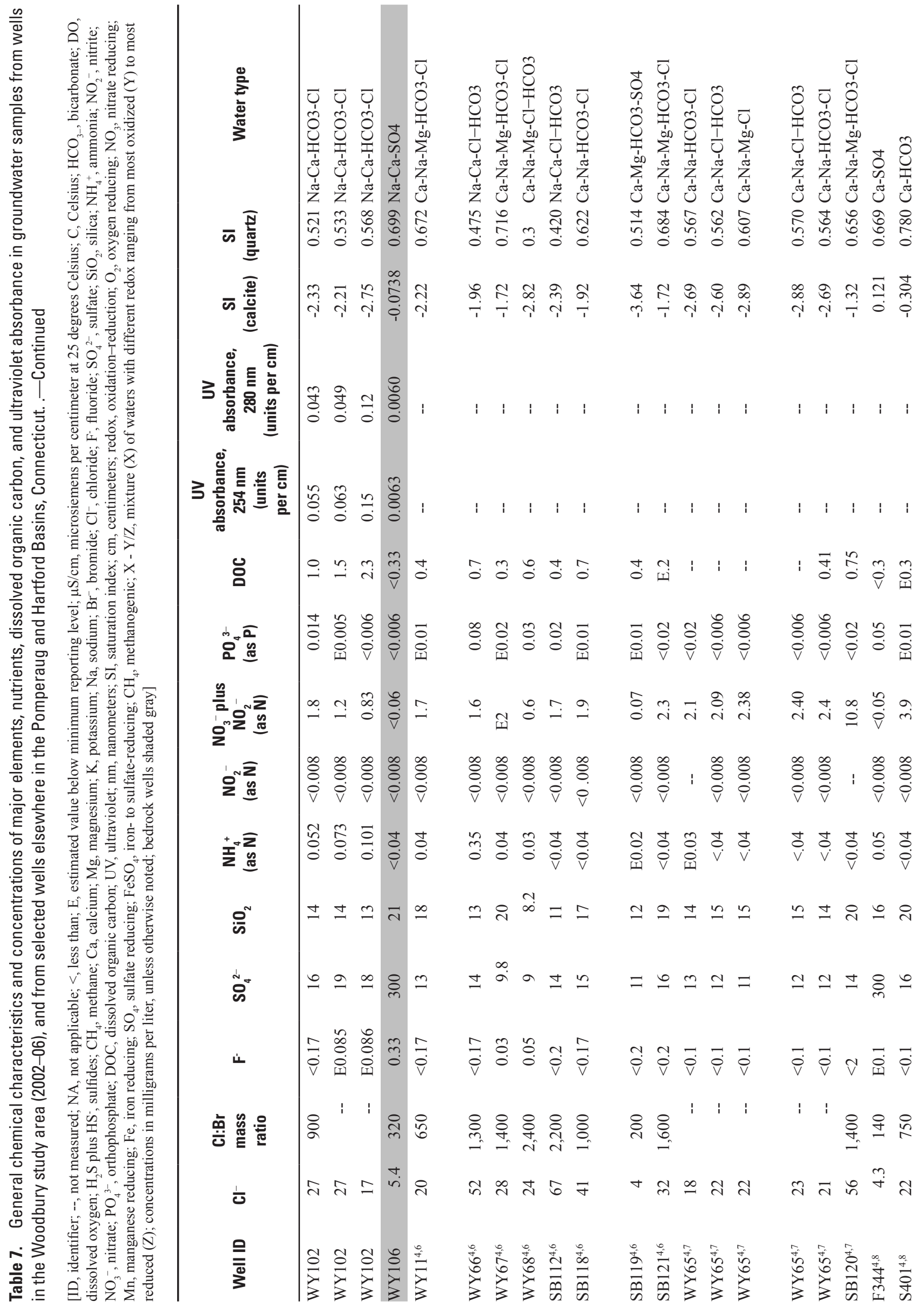




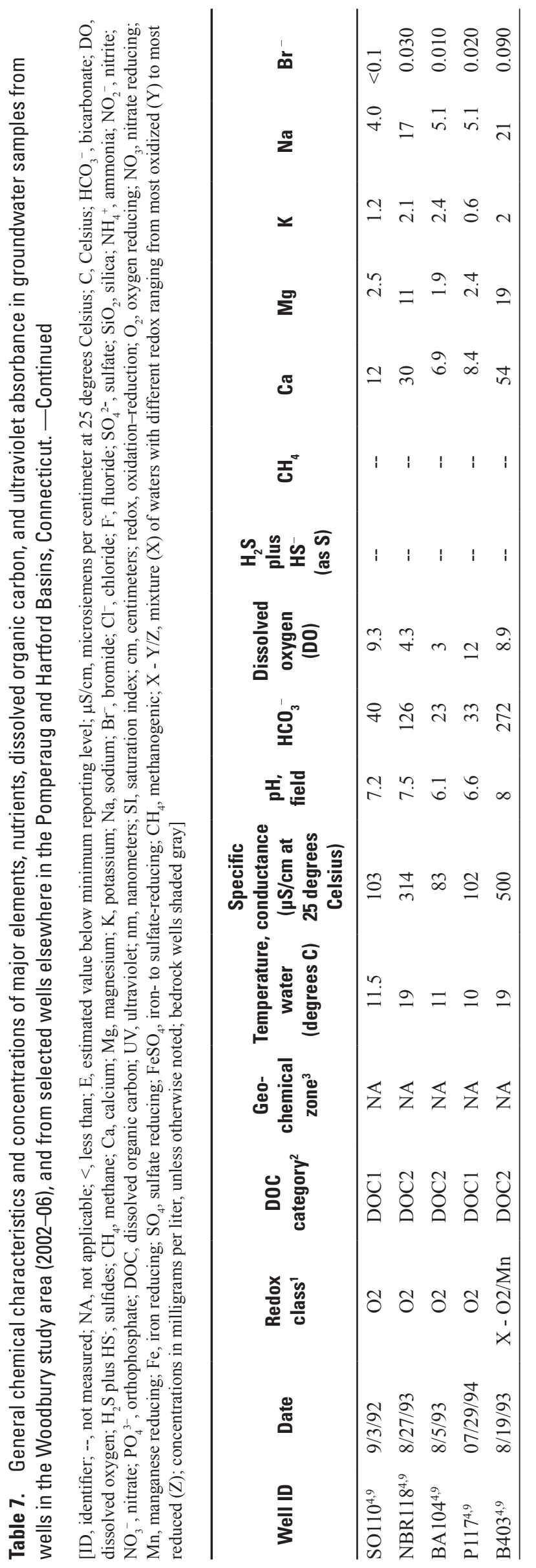




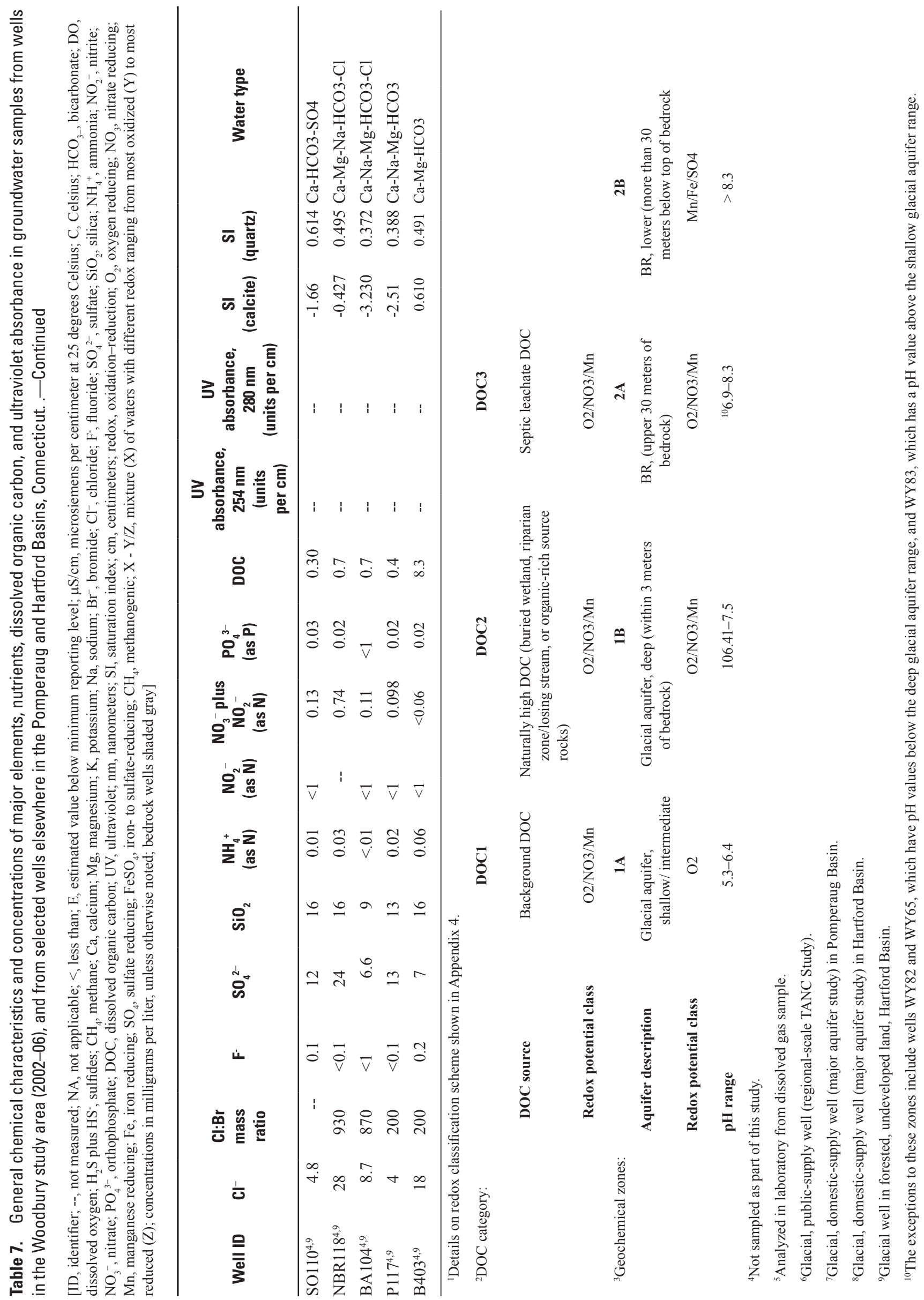




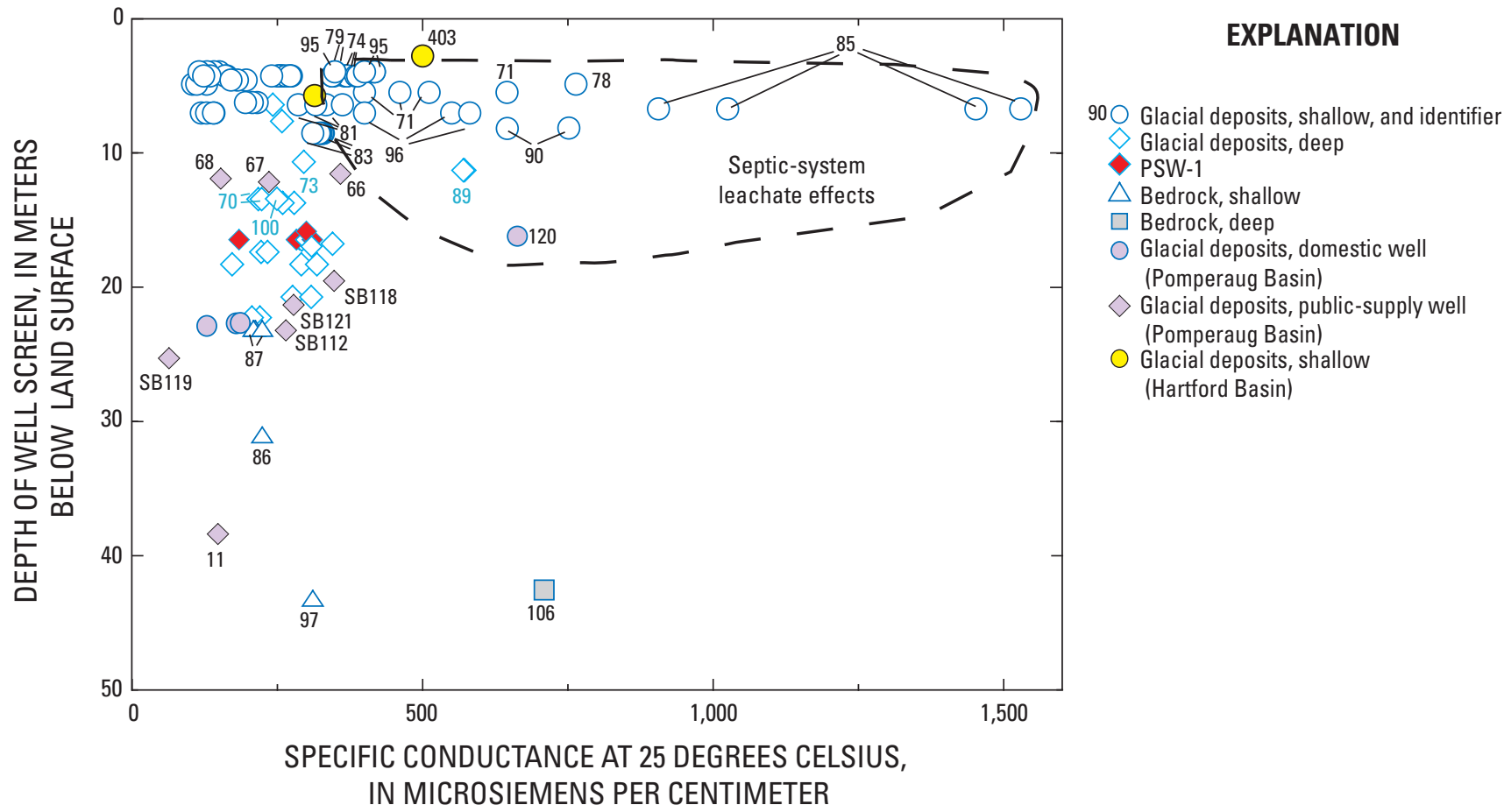

Figure 11. Specific conductance as a function of depth of well screen below land surface for groundwater samples from wells in the Woodbury study area, and from selected wells elsewhere in the Pomperaug and Hartford Basins, Connecticut.

with the Taine Mountain Formation (fig. 2). Bedrock well WY106, however, is screened deeper in the Orenaug Basalt and had much different groundwater chemistry than other bedrock wells sampled - most notably high concentrations of $\mathrm{SO}_{4}^{2-}$ (table 7; fig. 14B), as well as $\mathrm{Na}$ and $\mathrm{Ca}$ and other constituents (B, F, Li, Mo, Se, $\mathrm{Sr}$, and $\mathrm{Zn}$; table 8). The $\mathrm{SO}_{4}^{2-}$ concentration of $300 \mathrm{mg} / \mathrm{L}$ in groundwater from WY106 exceeded the National Secondary Drinking Water Regulations of $250 \mathrm{mg} / \mathrm{L}$ (USEPA, 2006b). WY106 has some similarities in chemistry to that of some glacial aquifer wells that overlie Mesozoic rocks in the Hartford and Newark Basins. The water sample from well F344, for example, had similar major-ion chemistry to the sample from well WY106 (low $\mathrm{Cl}^{-}$, high $\mathrm{SO}_{4}{ }^{2-}$ ), although the $\mathrm{F} 344$ sample had lower concentrations of $\mathrm{Na}$ and higher concentrations of $\mathrm{Ca}, \mathrm{Mg}$, and $\mathrm{HCO}_{3}{ }_{3}^{-}$than did WY106, which probably reflect interbasinal variations in chemistry of lithologic units (fig. 13; tables 7 and 8). Rock samples from Mesozoic shales of the Hartford Basin are enriched in B (van de Kamp and Leake, 1996; p. 107) and $\mathrm{Ba}$ (Hubert and others, 1992) relative to other Mesozoic rocks. The concentration of $\mathrm{Ba}$ in the water sample from WY106 was relatively low, however.

Several domestic bedrock wells in the valley bottom have been reported to contain high concentrations of $\mathrm{SO}_{4}^{2-}$, including a sample with $1,300 \mathrm{mg} / \mathrm{L} \mathrm{SO}_{4}^{2-}$ from a well that is located about $2 \mathrm{~km}$ north of WY106 (J.L. Pond, Pomperaug River Watershed Coalition, oral commun., 2003) and another from a well $0.4 \mathrm{~km}$ to the north. Several residents in the study area with domestic bedrock wells deeper than about $45 \mathrm{~m}$ below land surface reported poor water quality with high concentrations of $\mathrm{SO}_{4}{ }^{2-}$ and $\mathrm{Na}$. High concentrations of dissolved $\mathrm{Na}$ in the deep bedrock of the Pomperaug Basin are consistent with the abundance of albite overgrowths observed in Newark Supergroup rocks by other studies (Gray, 1988; Merino and others, 1997). Groundwater samples from sedimentary-bedrock aquifers in the Newark Supergroup of the Passaic River Basin in New Jersey had high concentrations of $\mathrm{Ba}, \mathrm{Ca}, \mathrm{Mg}, \mathrm{Sr}$, and $\mathrm{SO}_{4}{ }^{2-}$ relative to those from other aquifers in that area, and $\mathrm{SO}_{4}^{2-}$ concentrations were directly related to well depths (Czarnik and Kozinski, 1994). The dissolved molar ratio of $\mathrm{SO}_{4}{ }^{2-}$ to $\mathrm{Ca}$ (fig. 14B) is $1: 1$, consistent with gypsum dissolution, for several samples from wells screened in deep glacial deposits. Well WY106, screened in the underlying basalt, had the highest $\mathrm{SO}_{4}^{2-}$ concentration, which might reflect prior dissolution of gypsum and, locally, subsequent dedolomitization along the flow path. Dedolomitization is a process, whereby, as a result of gypsum or anhydrite dissolution, dolomite dissolves and calcite precipitates (Plummer and others, 1990). Dolomite is present in Mesozoic rocks in the Pomperaug Basin but is mainly 


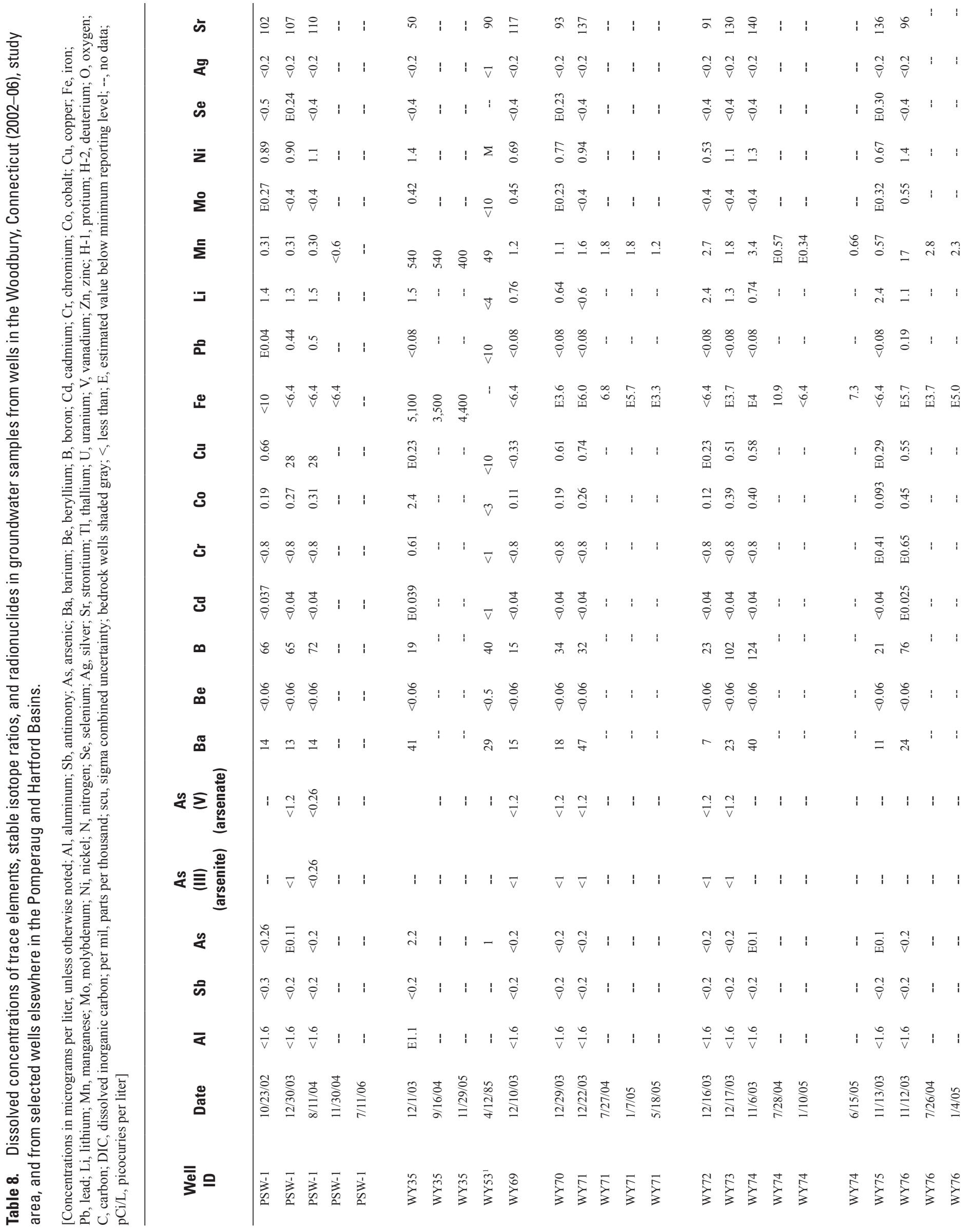




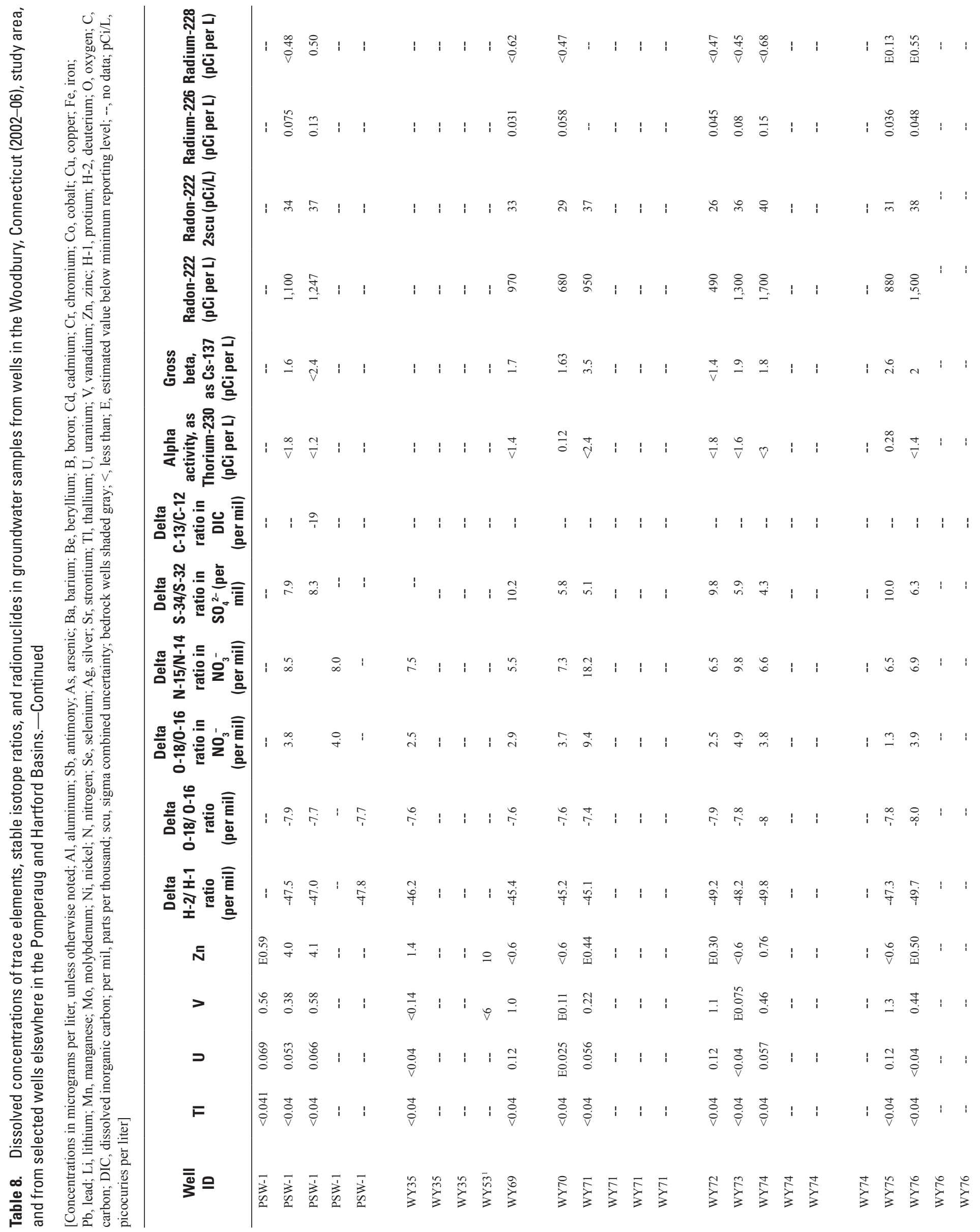




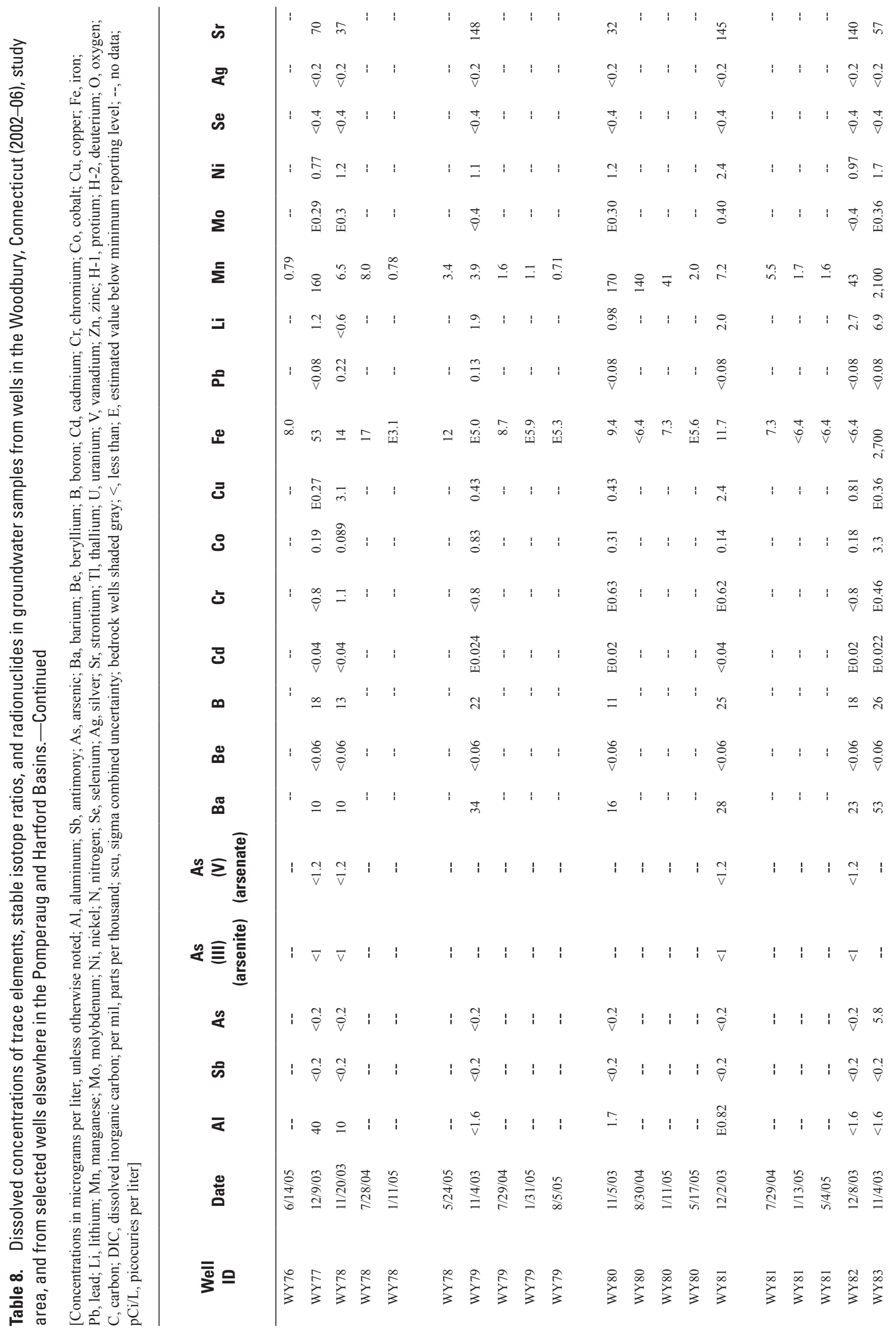




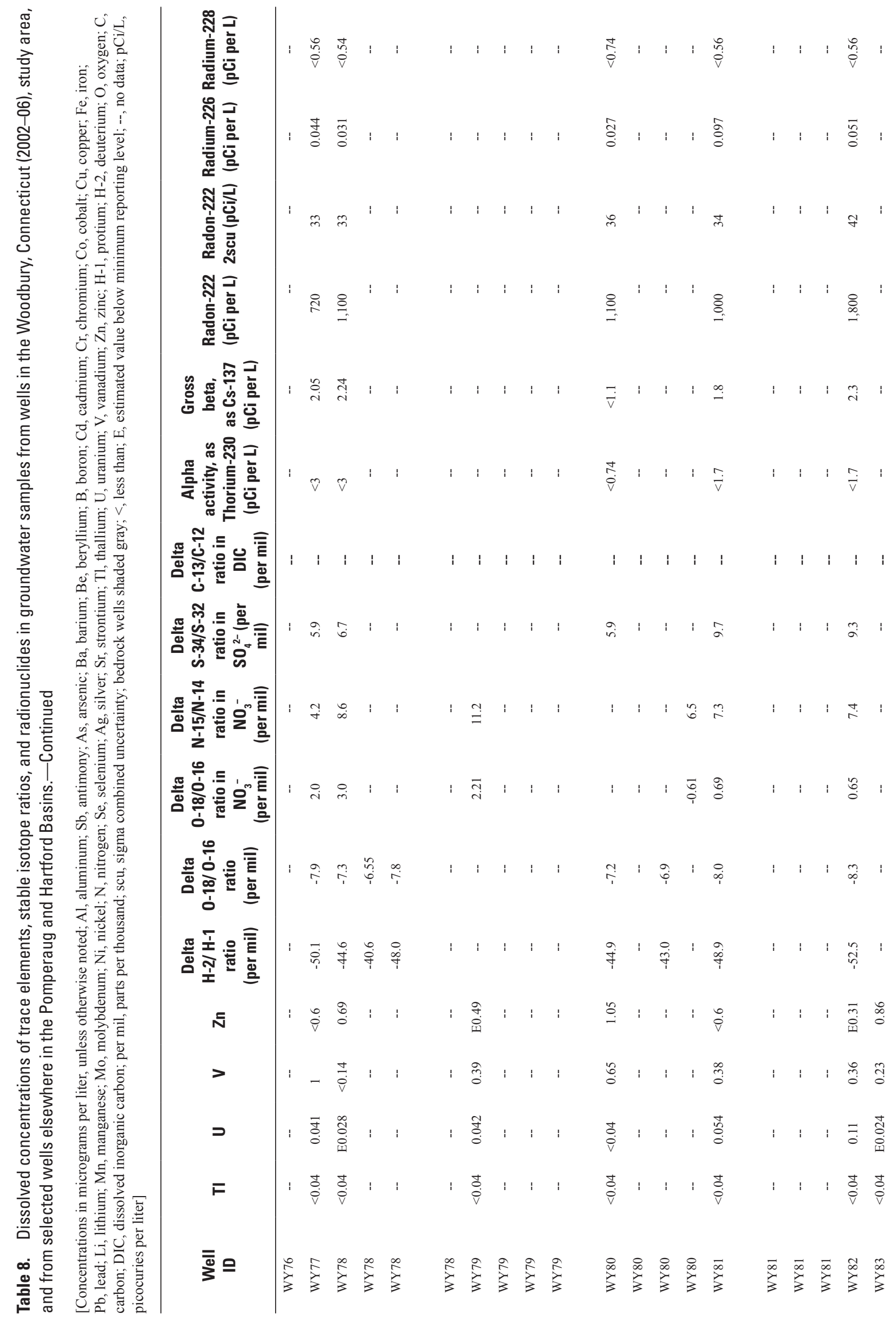




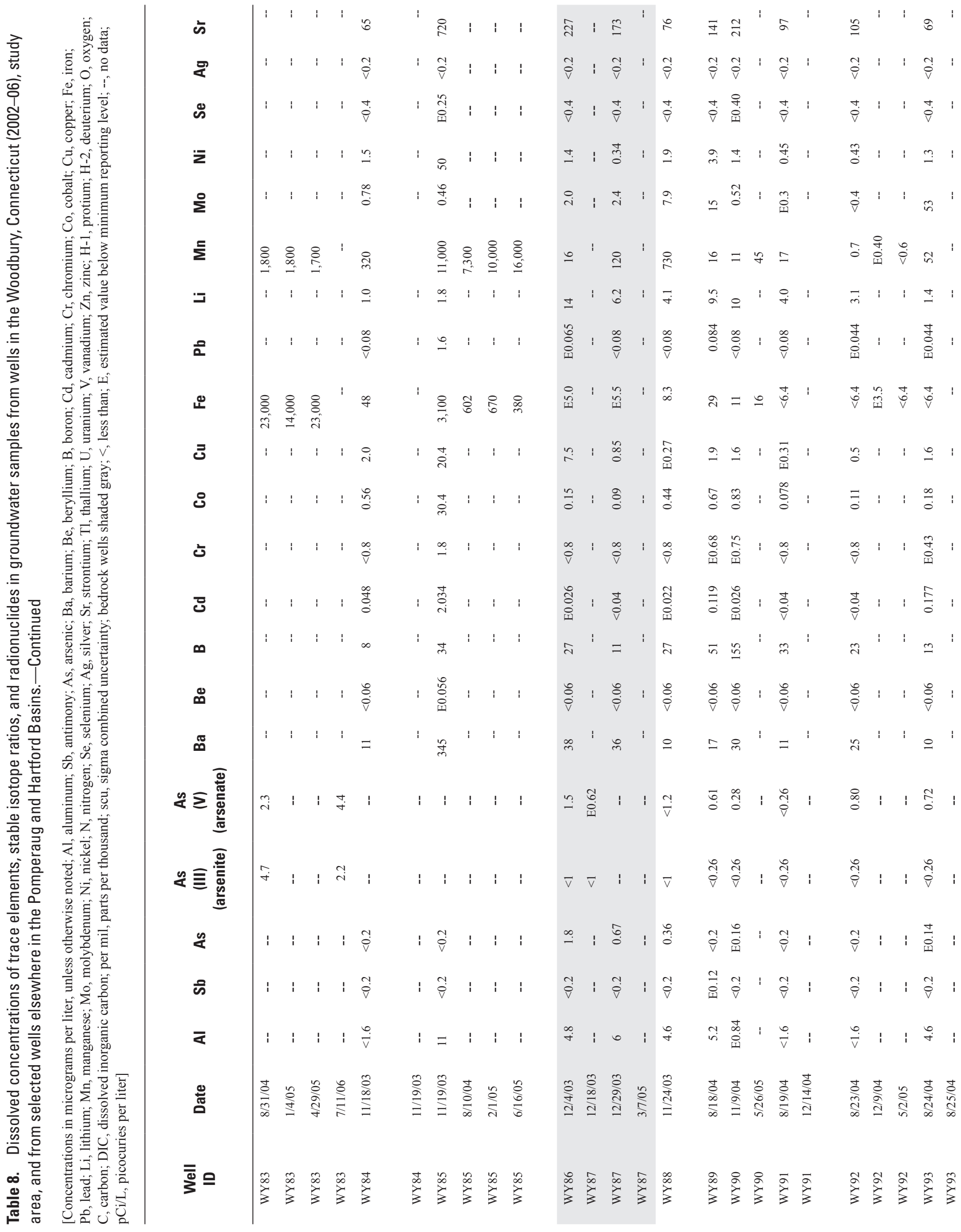




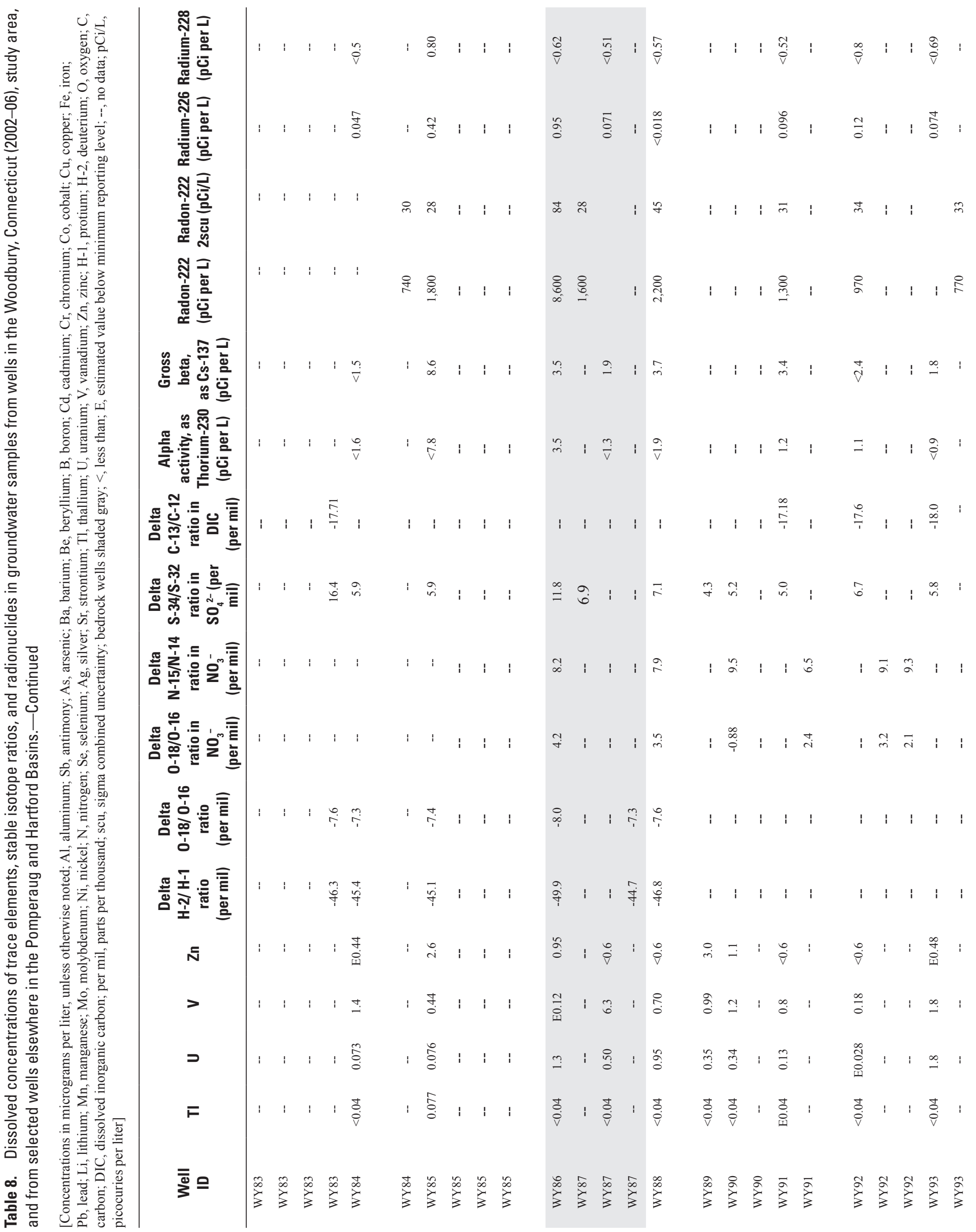




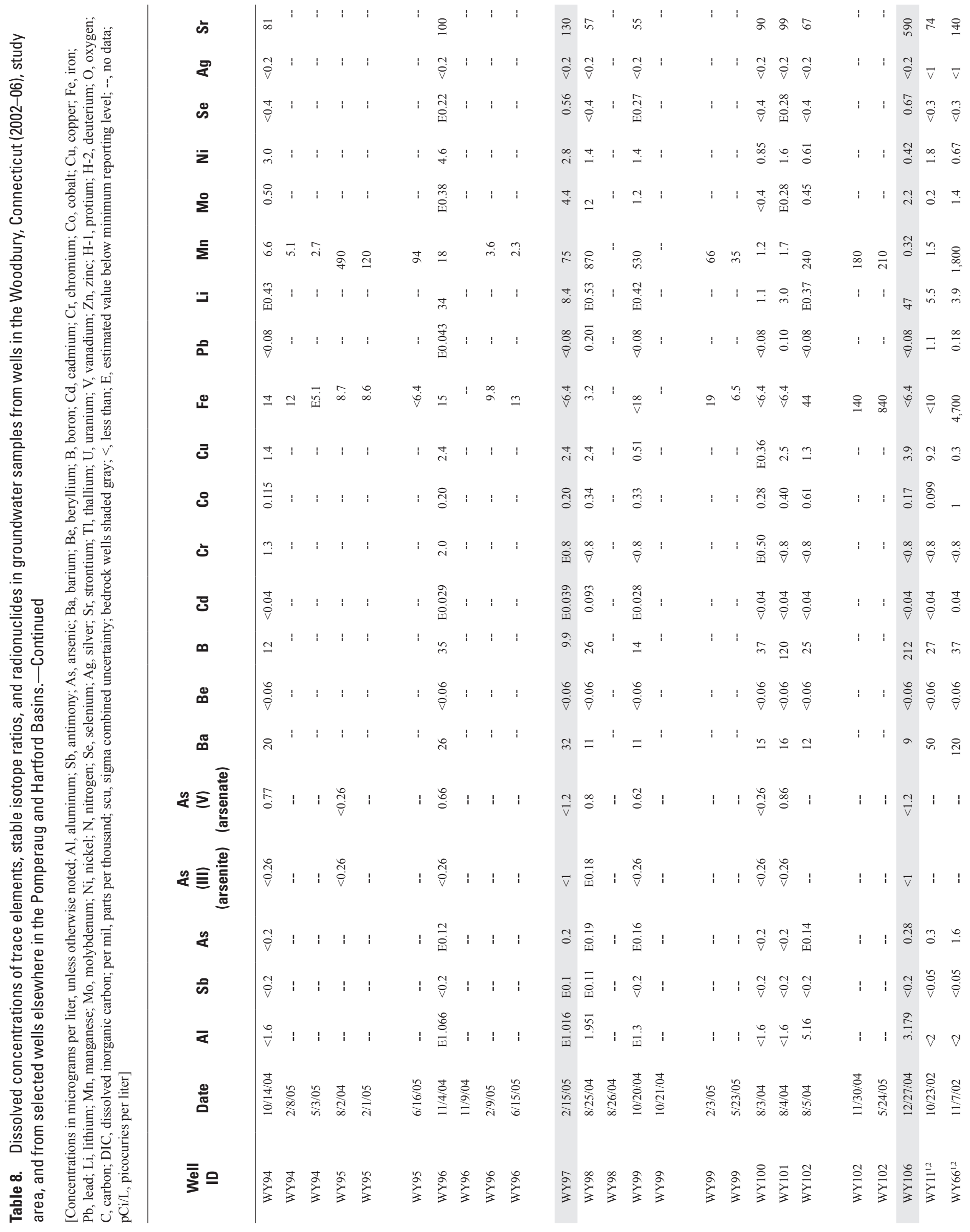




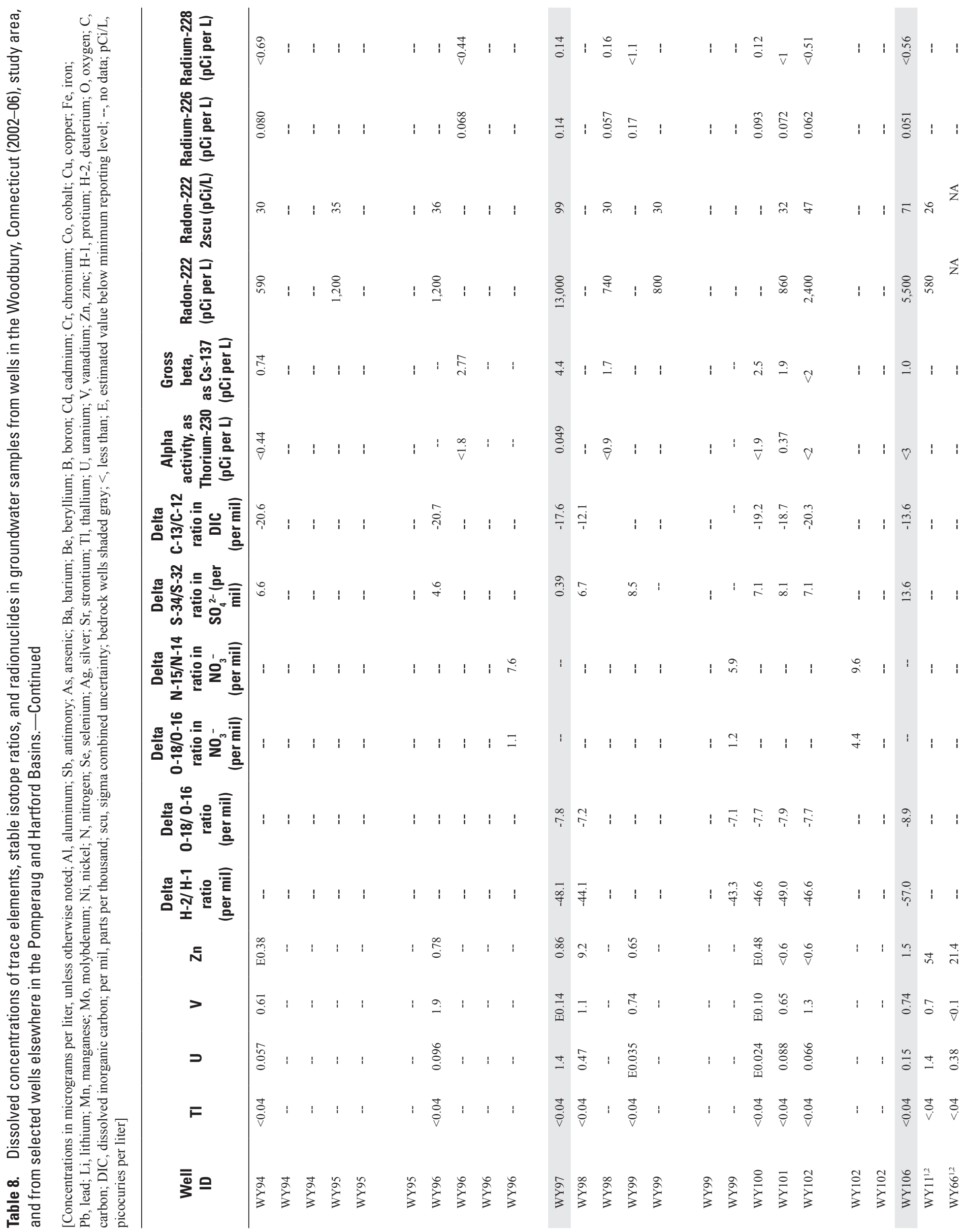




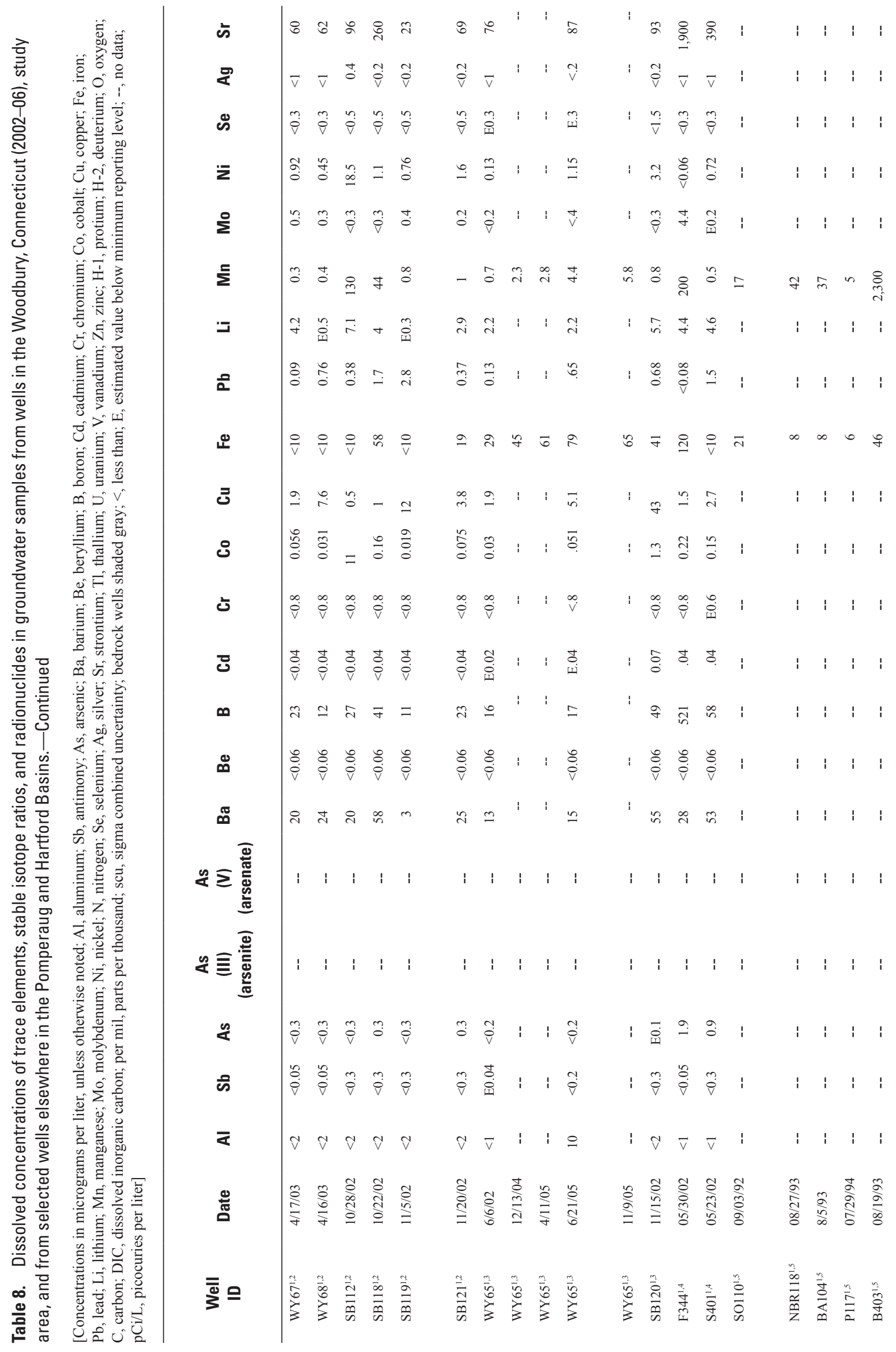




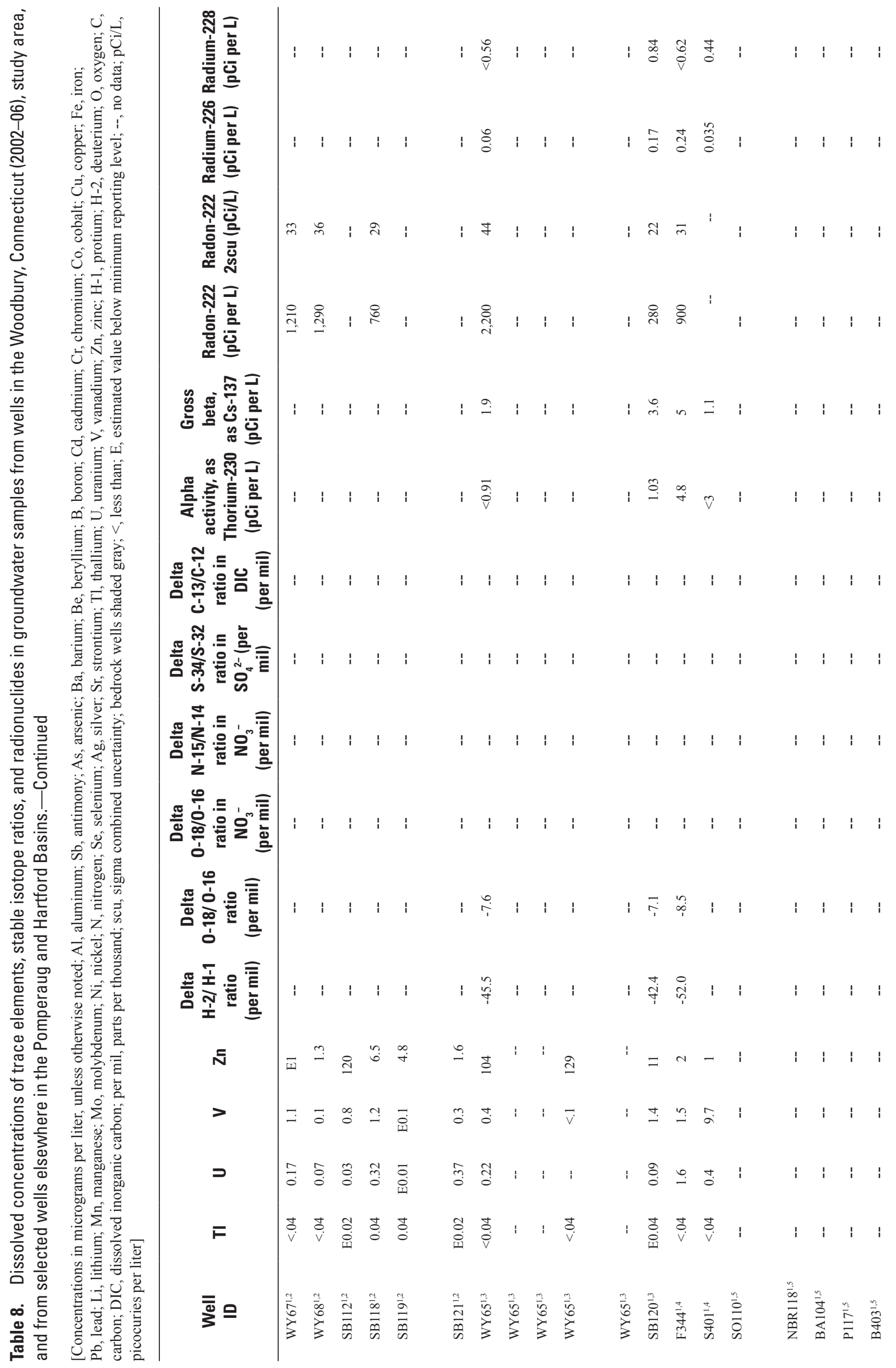




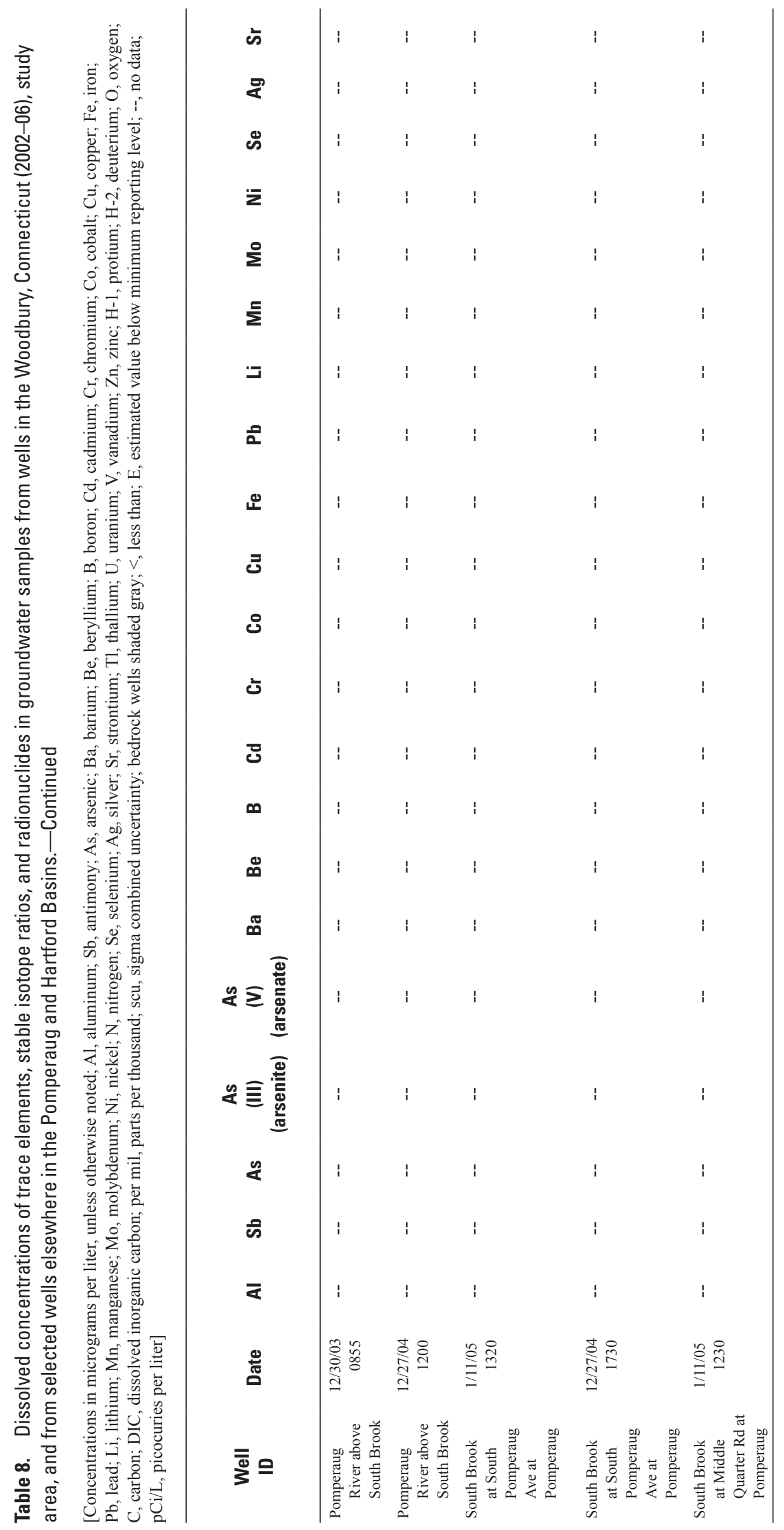




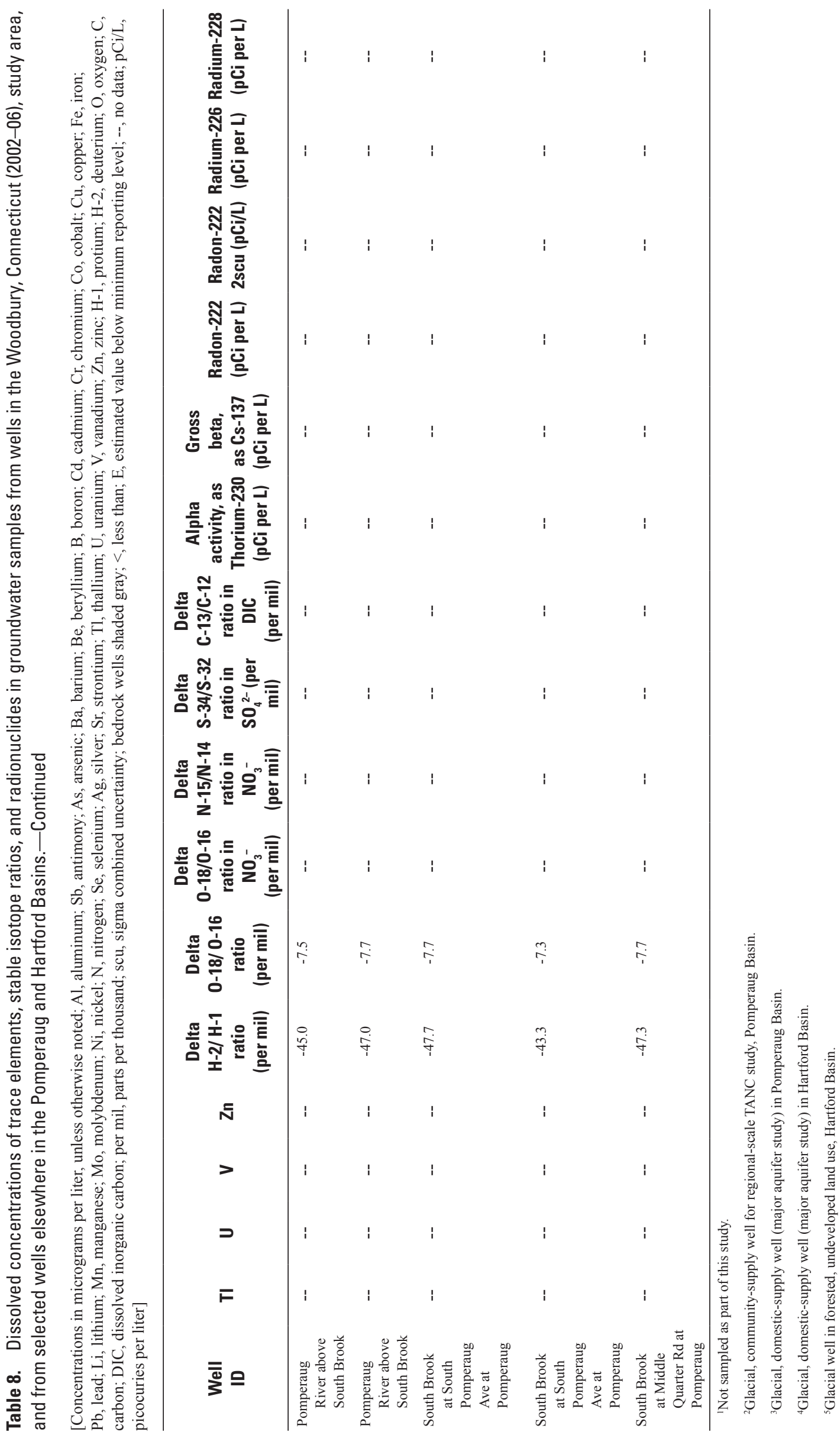




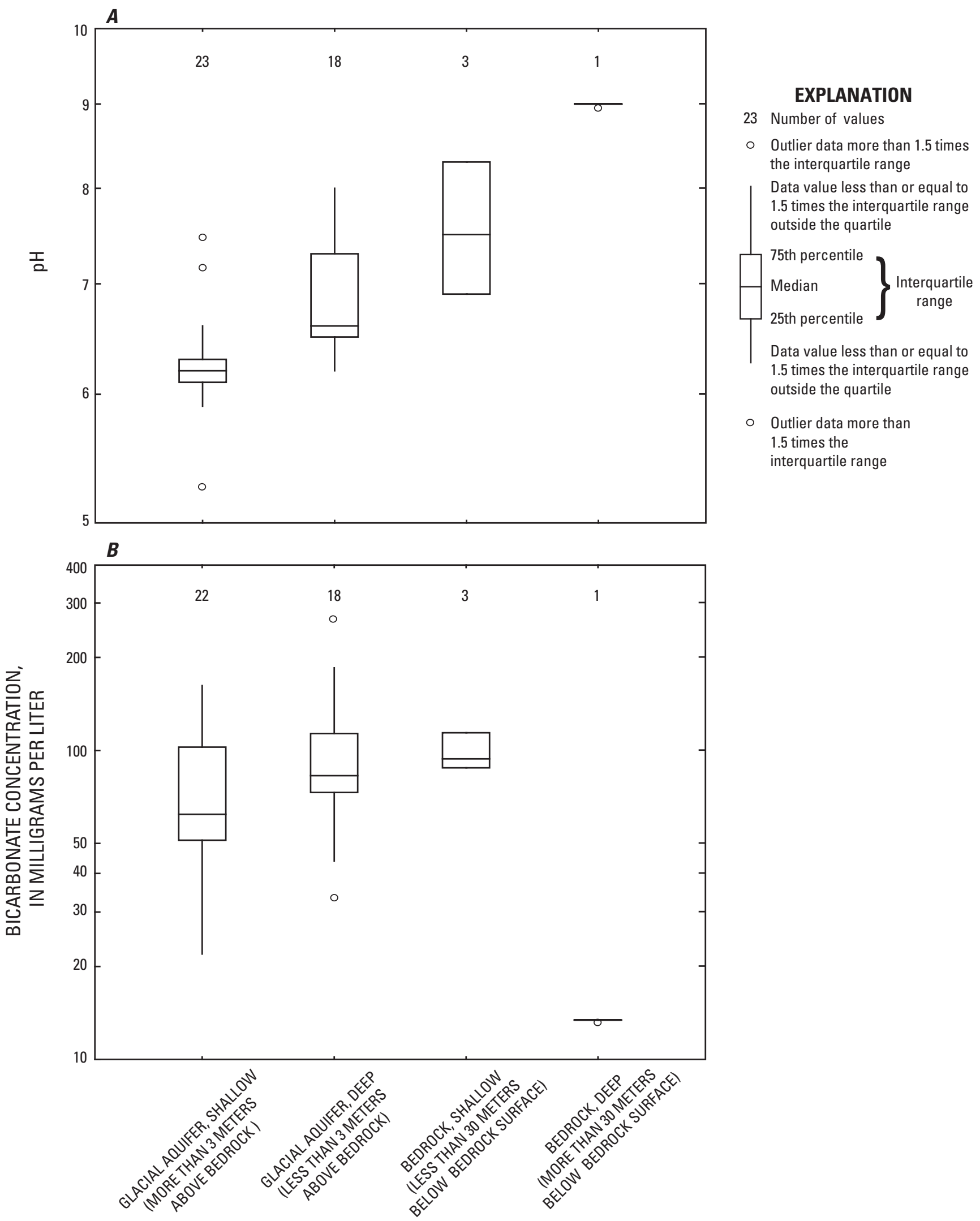

Figure 12. Distribution of $(A) \mathrm{pH}$, and $(B)$ bicarbonate concentrations in groundwater samples from well screens in the (1) shallow parts of the glacial aquifer, greater than 3 meters above bedrock, (2) deep glacial aquifer, less than 3 meters above bedrock, (3) shallow bedrock, less than 30 meters below bedrock surface, and (4) deep bedrock, greater than 30 meters below bedrock surface in the study area, Woodbury, Connecticut. 


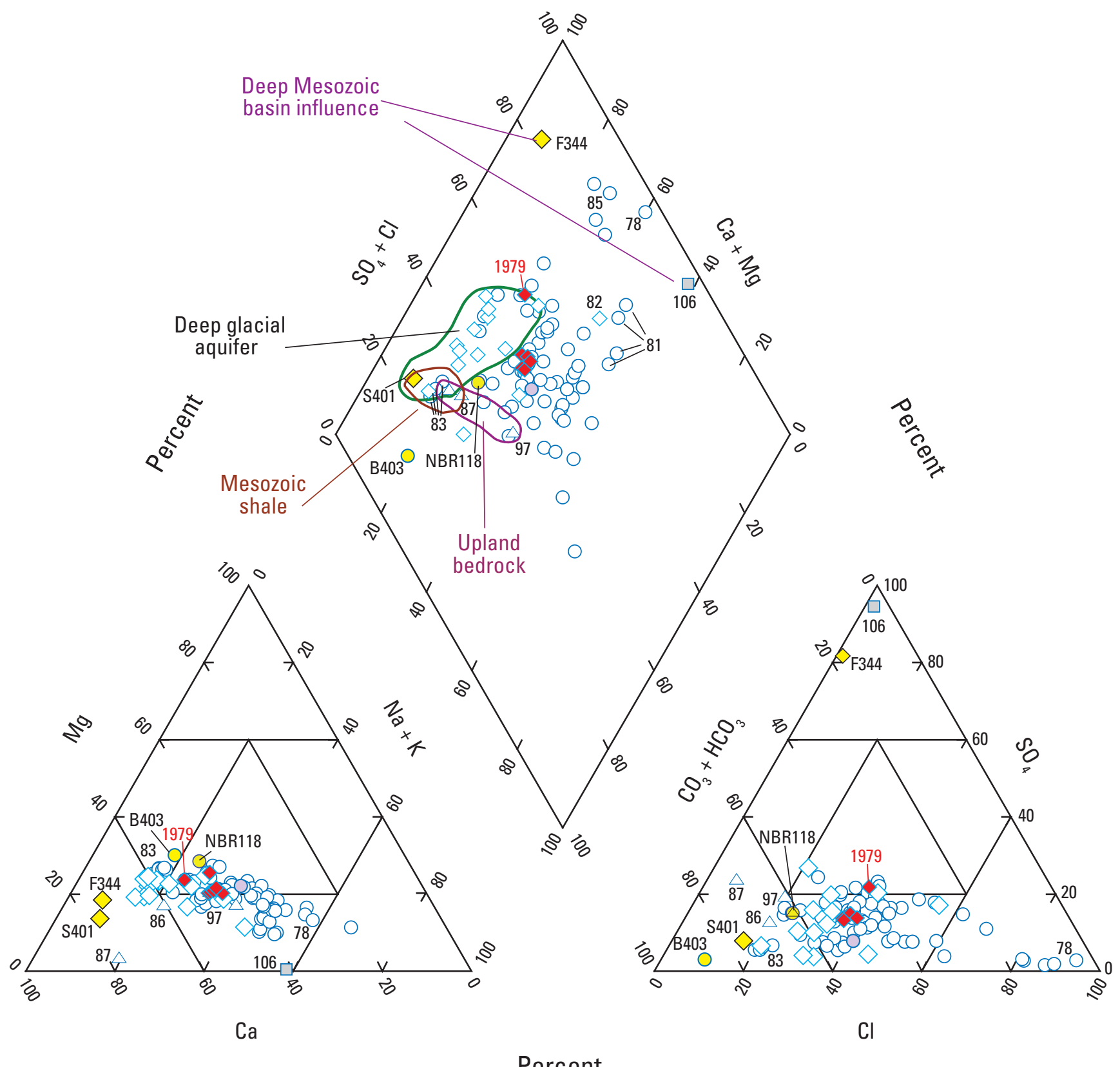

Percent

\section{EXPLANATION}

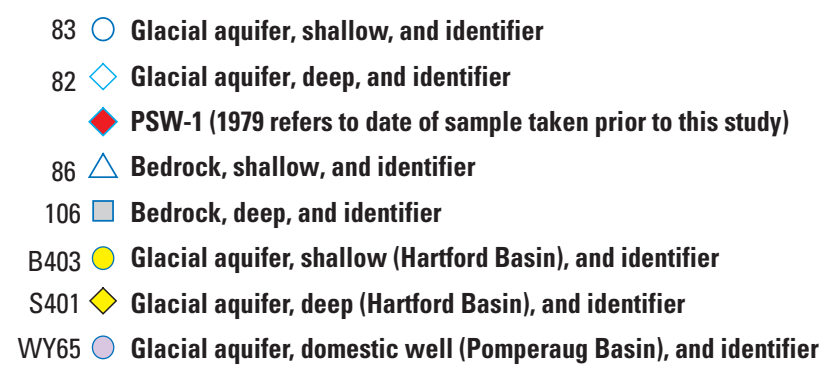

Figure 13. Piper diagram showing the percentage of total equivalents of major cations and anions in groundwater samples from wells in the Woodbury study area, and from selected wells elsewhere in the Pomperaug and Hartford Basins, Connecticut. 

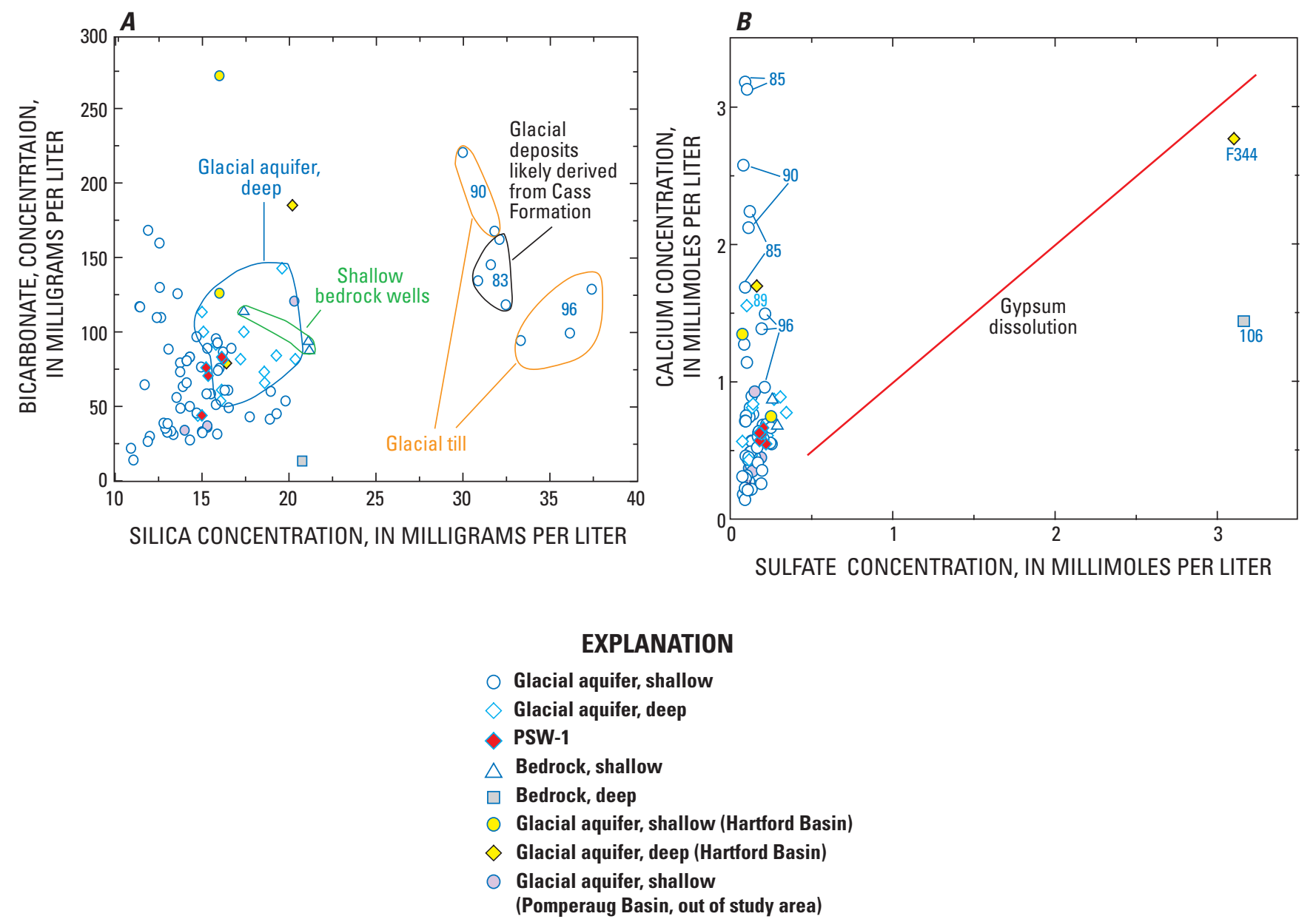

Figure 14. Concentrations of $(A)$ silica as a function of bicarbonate and $(B)$ calcium as a function of sulfate in groundwater samples from wells in the Woodbury study area, and from selected wells elsewhere in the Pomperaug and Hartford Basins, Connecticut.

restricted to cements in some lacustrine deposits (Hubert and others, 1992; Krynine, 1950). Furthermore, concentrations of $\mathrm{Mg}$ in the representative deep bedrock well (WY106) were very low and do not support dissolution of dolomite after the dissolution of gypsum and precipitation of calcite.

Other wells screened in glacial deposits appear to be affected by underlying Mesozoic shales. Data representing the major-ion distributions of samples from WY83, as depicted in figure 13, plotted near the ion distributions for bedrock wells and also near those for wells S403, S401, and NBR118 that tap groundwater from glacial deposits that overlie Mesozoic rocks in the Hartford Basin. Major-ion ratios in samples from these wells appear to reflect interaction with the Cass Formation and the Shuttle Meadow Formation, respectively, and do not appear to be affected by basinal fluids or older ( $>50$ years), deep groundwater with higher ionic strength. The low concentration of $\mathrm{SO}_{4}{ }^{2-}$ in samples from WY83, for example, likely reflects $\mathrm{SO}_{4}^{2-}$ reduction. Ca correlates well with $\mathrm{Mg}$ for most samples (fig. 15A) and likely is related to the distribution of calcite or other carbonate minerals in bedrock and glacial till deposits and to various anthropogenic activities and sources, including liming of lawns, road salting, and septicsystem leachate, and associated cation exchange. Cations such as $\mathrm{Na}$ and $\mathrm{Ca}$, and anions such as $\mathrm{Cl}^{-}$are associated with road salting (Panno and others, 2006). Road-salt runoff is indicated by the high concentrations of $\mathrm{Na}^{+}$and $\mathrm{Cl}^{-} ; \mathrm{Na}^{+}$and $\mathrm{Cl}^{-}$concentrations in some samples plot along a 1:1 line (for example, halite in road salt), but some samples show relatively high concentrations of $\mathrm{Cl}^{-}$(fig. 15B), which may indicate other sources and preferential sorption of $\mathrm{Na}^{+}$over $\mathrm{Cl}^{-}$. Water samples from well WY85, which is near a septic-tank drainfield, have particularly high concentrations of $\mathrm{Cl}^{-}$and appear to be affected by septic-system leachate, as discussed later in this section.

Plots of the relation between $\mathrm{Cl}^{-}$concentrations and $\mathrm{Cl}: \mathrm{Br}$ mass-concentration ratios were used to help determine the 


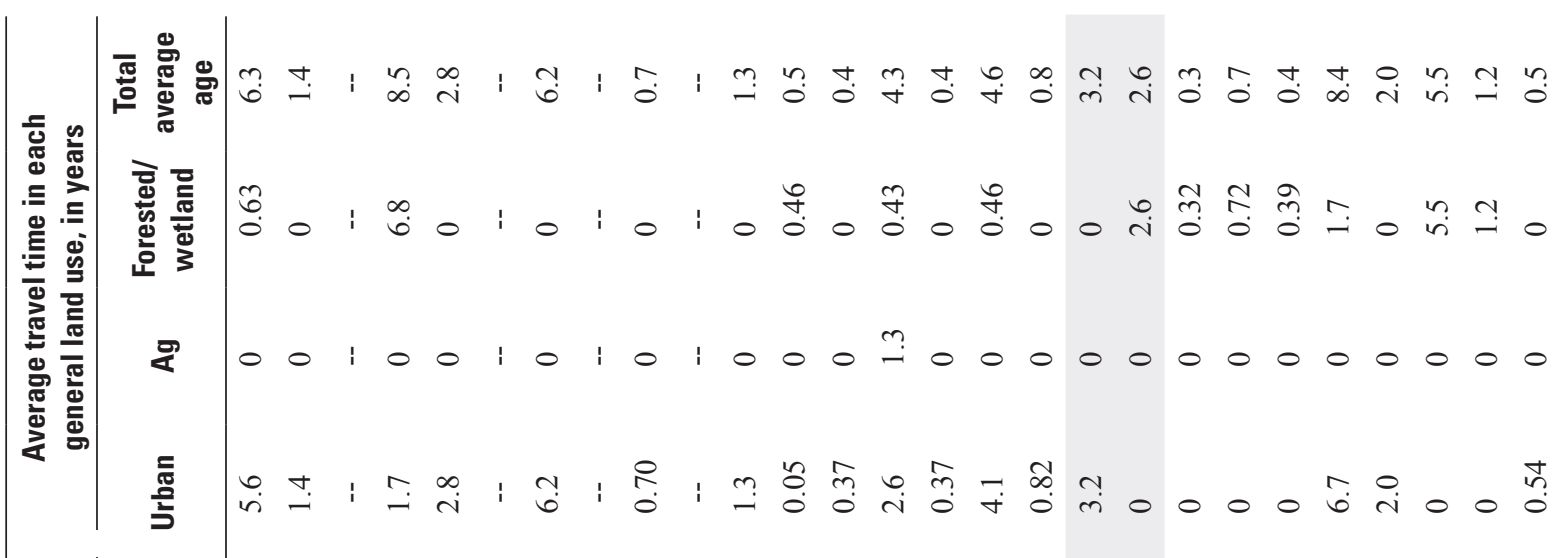

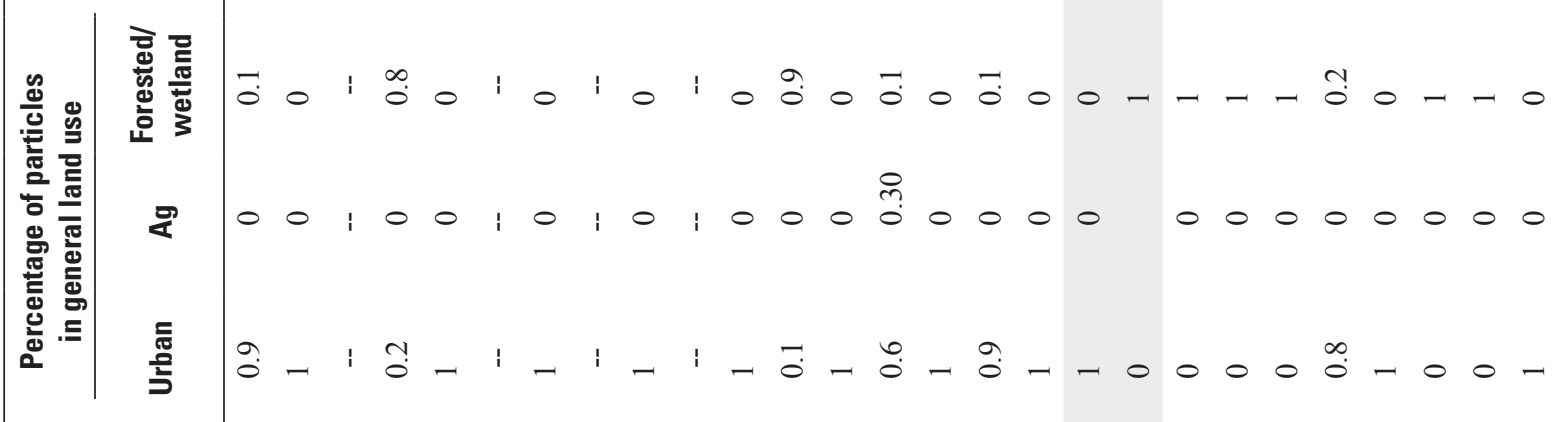

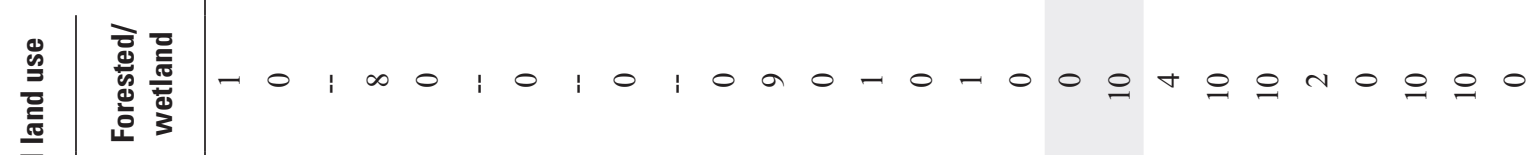
$800100: 0: 01000 m 0000000000000$ $a \circ:$ i

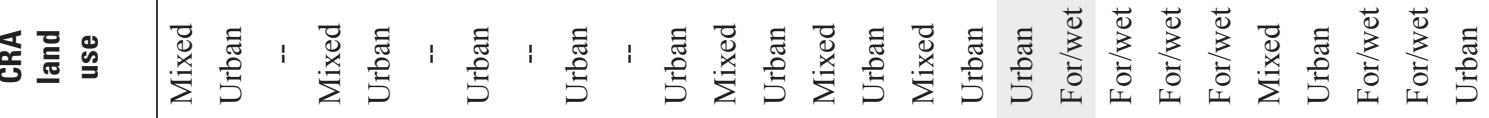

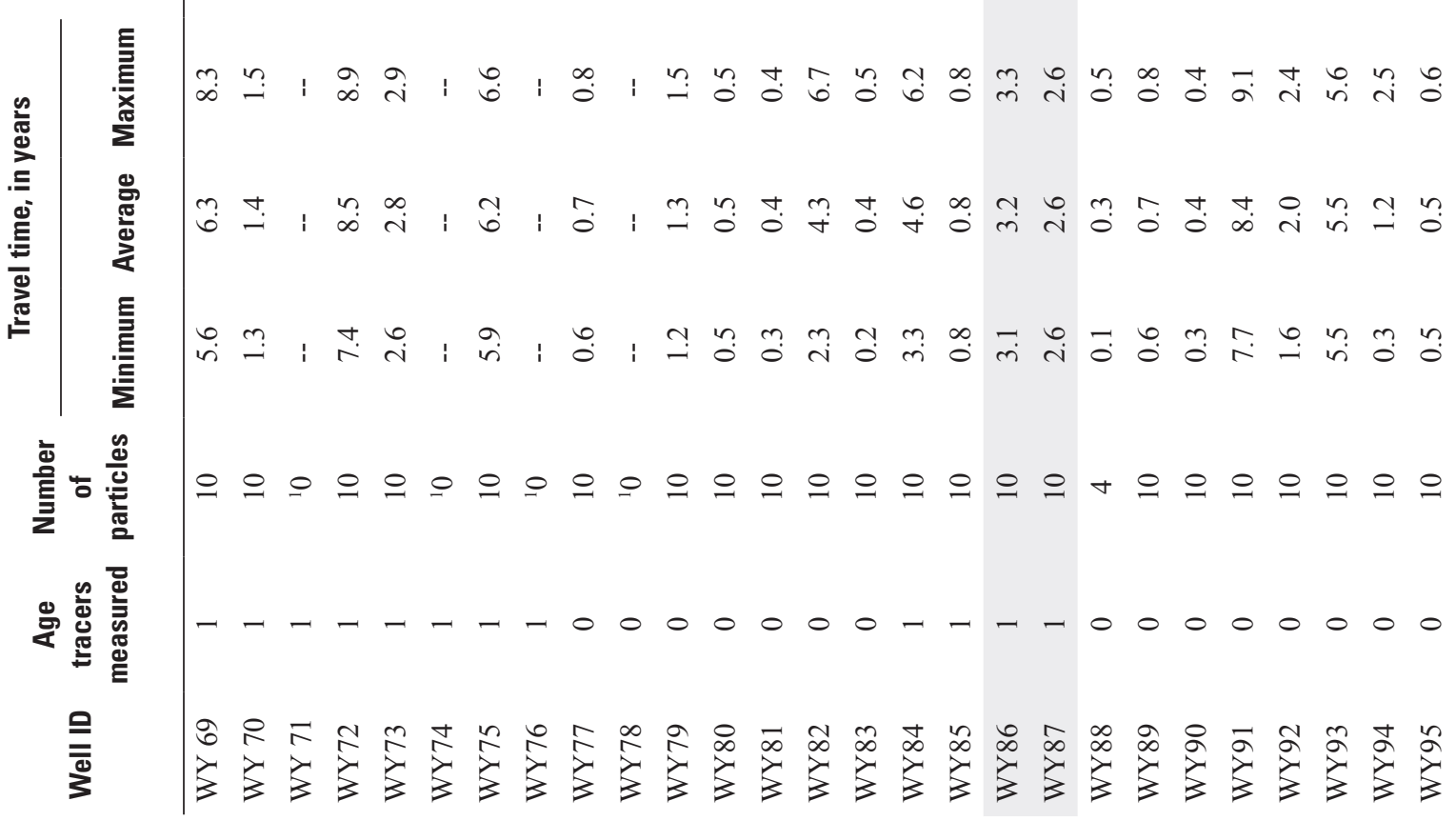




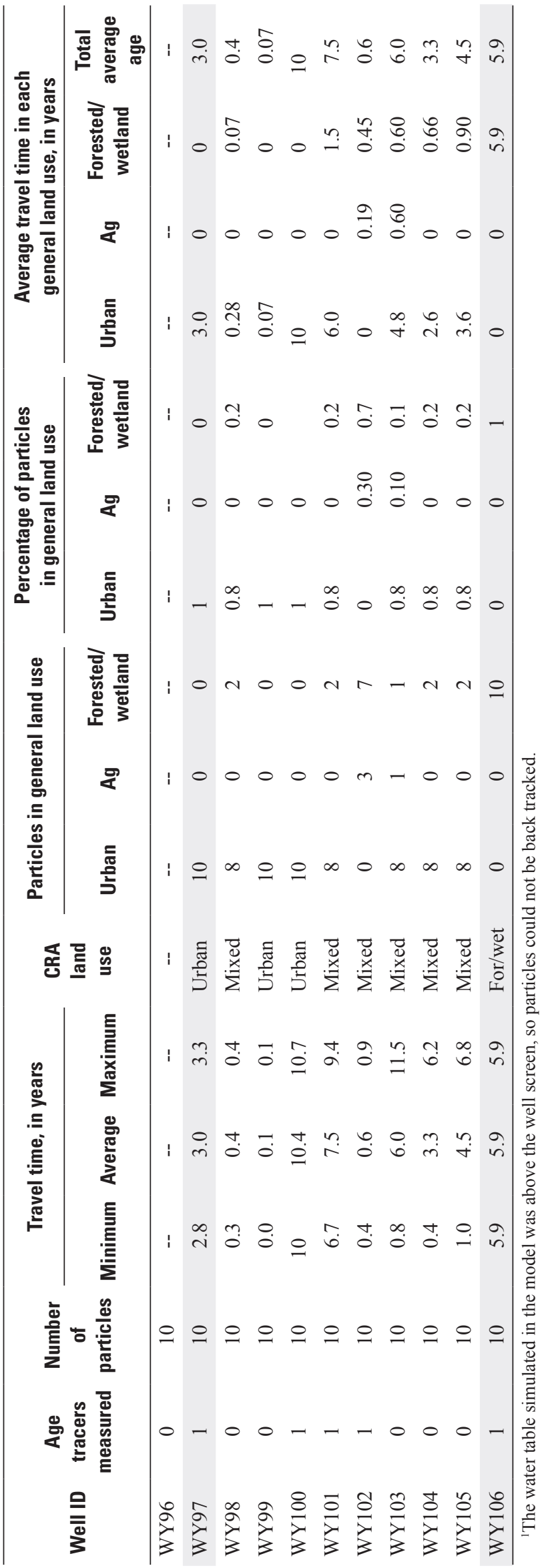



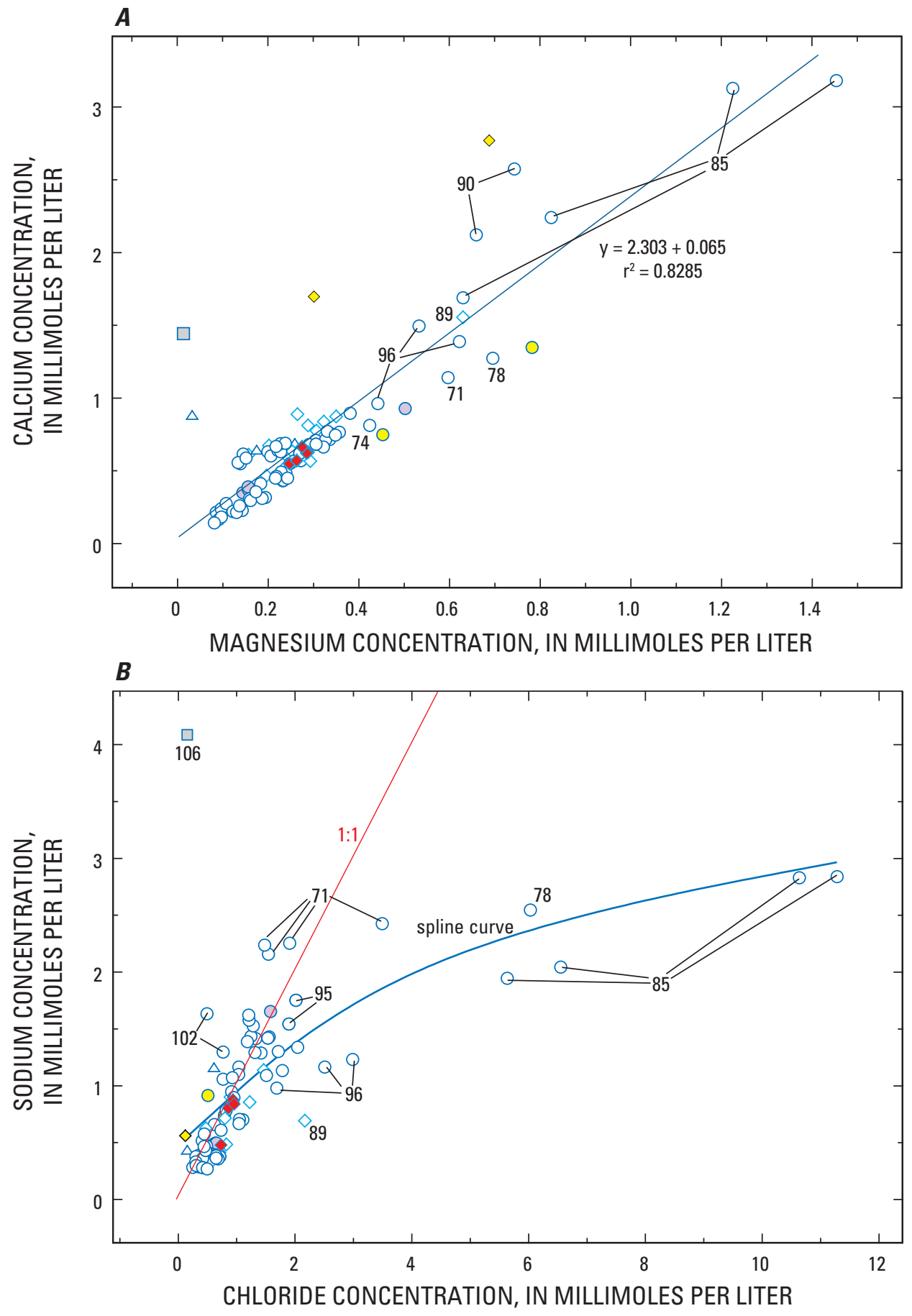

\section{EXPLANATION}

$90 \bigcirc$ Glacial aquifer, shallow, and identifier $\diamond$ Glacial aquifer, deep PSW-1

$\triangle$ Bedrock, shallow 106 $\square$ Bedrock, deep

O Glacial aquifer, shallow (Hartford Basin)

$\diamond$ Glacial aquifer, deep (Hartford Basin)

O Glacial aquifer, domestic well (Pomperaug Basin)

Figure 15. Concentrations of $(A)$ magnesium as a function of calcium, and $(B)$ chloride as a function of sodium, in groundwater samples from wells in the Woodbury study area, and from selected wells elsewhere in the Pomperaug and Hartford Basins, Connecticut. 
effects of anthropogenic sources or activities on groundwater chemistry (table 7, fig. 16). Concentrations of $\mathrm{Cl}^{-}$and $\mathrm{Br}$ are useful in distinguishing several sources because of their conservative nature in water, because they have different abundances in natural fluids and most solids (Davis and others, 1998), and because natural halite deposits are nonexistent in the Pomperaug aquifer system. Plots of $\mathrm{Cl}^{-}$concentrations and $\mathrm{Cl}: \mathrm{Br}$ ratios have been used to determine the effects of road salt, sewage, and seawater or brines on groundwater quality (Davis and others, 1998; Vengosh and Pankratov, 1998; Thomas, 2000; Panno and others, 2006). Although both $\mathrm{Cl}^{-}$and $\mathrm{Br}^{-}$have similar sources and behave similarly geochemically (Fuge, 1969), $\mathrm{Cl}^{-}$is generally 40 to 8,000 times as abundant as $\mathrm{Br}^{-}$, and $\mathrm{Cl}^{-}$has a slightly lower solubility than does $\mathrm{Br}^{-}$(Davis and others, 1998). Atmospheric deposition is the primary source of $\mathrm{Cl}^{-}$and $\mathrm{Br}^{-}$in pristine groundwater in the study area. $\mathrm{Cl}: \mathrm{Br}$ ratios in precipitation typically range from 50 to 100; near the coast, ratios generally are about 290, similar to seawater, and decrease with distance from the ocean to a low of 20 to 56 in the midwestern United States (Panno and others, 2006). Seawater has an average $\mathrm{Cl}^{-}$concentration of about $19,500 \mathrm{mg} / \mathrm{L}$ and an average $\mathrm{Br}^{-}$concentration of about 290 (Davis and others, 1998). $\mathrm{Cl}^{-}$and $\mathrm{Br}^{-}$concentrations and their ratios for several sources relevant to the Woodbury study area, including previously published values, and those for well samples in other areas are shown in table 10. A graph of $\mathrm{Cl}^{-}$concentrations and $\mathrm{Cl}: \mathrm{Br}$ mass ratios shows the values for well samples relative to previously published source values or ranges for road salt (halite), domestic septic-system leachate (sewage), and seawater (fig. 16). Mixing lines were calculated between assumed end points for dilute groundwater and road salt (halite), domestic septic-system leachate (sewage), and seawater.

$\mathrm{Cl}^{-}$concentrations and $\mathrm{Cl}: \mathrm{Br}$ ratios in the Pomperaug glacial aquifer were affected to some extent by three endmember sources - dilute groundwater, road salt (halite), and sewage (septic-system leachate) (fig. 16). Seawater does not appear to be a direct source of $\mathrm{Cl}^{-}$or $\mathrm{Br}^{-}$, given the distance from the well to the coast, but it is shown as an additional endpoint in figure 16 for illustrative purposes. The dilute groundwater end point is represented by a monitoring well (well SO110), which is completed in glacial stratified deposits overlying Mesozoic rocks in a forested, undeveloped area in north-central Connecticut. Groundwater samples from other wells in undeveloped parts of Connecticut (P117) and of the study area (for example, WY86 and WY106) generally had $\mathrm{Cl}^{-}$concentrations less than $10 \mathrm{mg} / \mathrm{L}$ and $\mathrm{Cl}$ :Br ratios less than 400, which is the ratio that Thomas (2000) considered to be the threshold for anthropogenic sources in the midwestern United States. $\mathrm{Cl}^{-}$and $\mathrm{Br}^{-}$concentrations in shallow groundwater should be similar to those in local atmospheric deposition but slightly more concentrated as a result of evapotranspiration and some interaction with shallow glacial or alluvial deposits. Because $\mathrm{Cl}^{-}$and $\mathrm{Br}^{-}$concentrations in atmospheric deposition are small, small amounts of $\mathrm{Cl}^{-}$and $\mathrm{Br}^{-}$from other sources will generally dominate the $\mathrm{Cl}$ : $\mathrm{Br}$ ratio.
The medians for $\mathrm{Cl}^{-}$concentrations $(10,000 \mathrm{mg} / \mathrm{L})$ and $\mathrm{Cl}: \mathrm{Br}$ ratios $(6,770)$ that were representative of halite road salt in Massachusetts (Granato, 1996) were used for the end point of halite. Halite is applied to roads for the treatment of snow and ice in the study area during the winter season and is the major source of $\mathrm{Cl}^{-}$. Groundwater samples that appeared to be affected by road-salt applications and by septic-tank drainfields had the largest deviation from dilute groundwater in the $\mathrm{Cl}$ :Br plots. Similarly, in a glacial aquifer in the Detroit, Michigan, metropolitan area, Thomas (2000) found that anthropogenic contaminants were closely related to elevated $\mathrm{Cl}: \mathrm{Br}$ ratios and surmised that the greatest effect on groundwater quality was from septic-system leachate and from road-salt runoff. $\mathrm{Cl}^{-}$concentrations and $\mathrm{Cl}: \mathrm{Br}$ ratios for most samples in the study area fall along the mixing curve between typical values for dilute groundwater and road salt (fig. 16). The $\mathrm{Br}^{-}$ion in halite is depleted relative to $\mathrm{Cl}^{-}$by a factor of 20 to 30 because the $\mathrm{Br}^{-}$ion is larger (Schoonen and others, 1995). The influx of $\mathrm{Na}$ from halite road salt acts to increase exchangeable cations and results in increased concentrations of $\mathrm{Ca}, \mathrm{Mg}$, and $\mathrm{K}$ in groundwater samples, particularly during the winter months (table 7). The town of Woodbury applied about 730 to 820 metric tons of halite per year to about $145 \mathrm{~km}$ of town roadways, which translates to about 5 to 6 metric tons per km of town roadway, during the 2004-2005 and 2005-2006 winter seasons. Road salt is probably applied to state roads at similar rates, although these roads can be wider, and the application rates may be higher.

Domestic and community sewage for the entire Woodbury, Connecticut, population is disposed of through on-site septic-tank drainfields, which can affect concentrations of $\mathrm{Cl}^{-}$and $\mathrm{Br}^{-}$, as well as $\mathrm{NO}_{3}^{-}$and $\mathrm{NH}_{4}^{+}, \mathrm{PO}_{4}^{3-}, \mathrm{B}$, and $\mathrm{DOC}$ (tables 7, 8, and 10). A median $\mathrm{Cl}^{-}$concentration of $91 \mathrm{mg} / \mathrm{L}$ and a $\mathrm{Cl}: \mathrm{Br}$ ratio of 769 , as determined for effluent from 29 private septic systems in the midwestern United States by Panno and others (2006), were used to represent the end point for septic-system leachate (fig. 16) because of the large number of septic-system samples from which it was derived. This end point is lower than the median $\mathrm{Cl}: \mathrm{Br}$ ratio of 1,197 and higher than the median $\mathrm{Cl}^{-}$concentration of $72 \mathrm{mg} / \mathrm{L}$ that were calculated for groundwater samples collected from wells downgradient from septic-tank drainfields in this study area; the median values were derived from samples from WY85, WY89, WY90, and WY95 (table 10). All these sites, particularly WY85 and WY95, are near roads or parking lots and probably are affected by halite road-salt runoff as well; the $\mathrm{Cl}^{-}$concentration of $400 \mathrm{mg} / \mathrm{L}$ in groundwater from WY85 exceeded the National Secondary Drinking Water Regulations of $250 \mathrm{mg} / \mathrm{L}$ (USEPA, 2006b). Septic-system leachate also can be affected by water-softener salt, which is generally $\mathrm{NaCl}$ (Panno and others, 2006), although water from glacial stratified deposits typically is soft (a sample of untreated water at PSW-1 had a total hardness of about $5 \mathrm{mg} / \mathrm{L}$ as $\mathrm{CaCO}_{3}$ ) and, therefore, is not likely to require softening. Domestic well SB120, which is $7 \mathrm{~km}$ to the south of the study area, also is downgradient from a previously failed septic-tank 

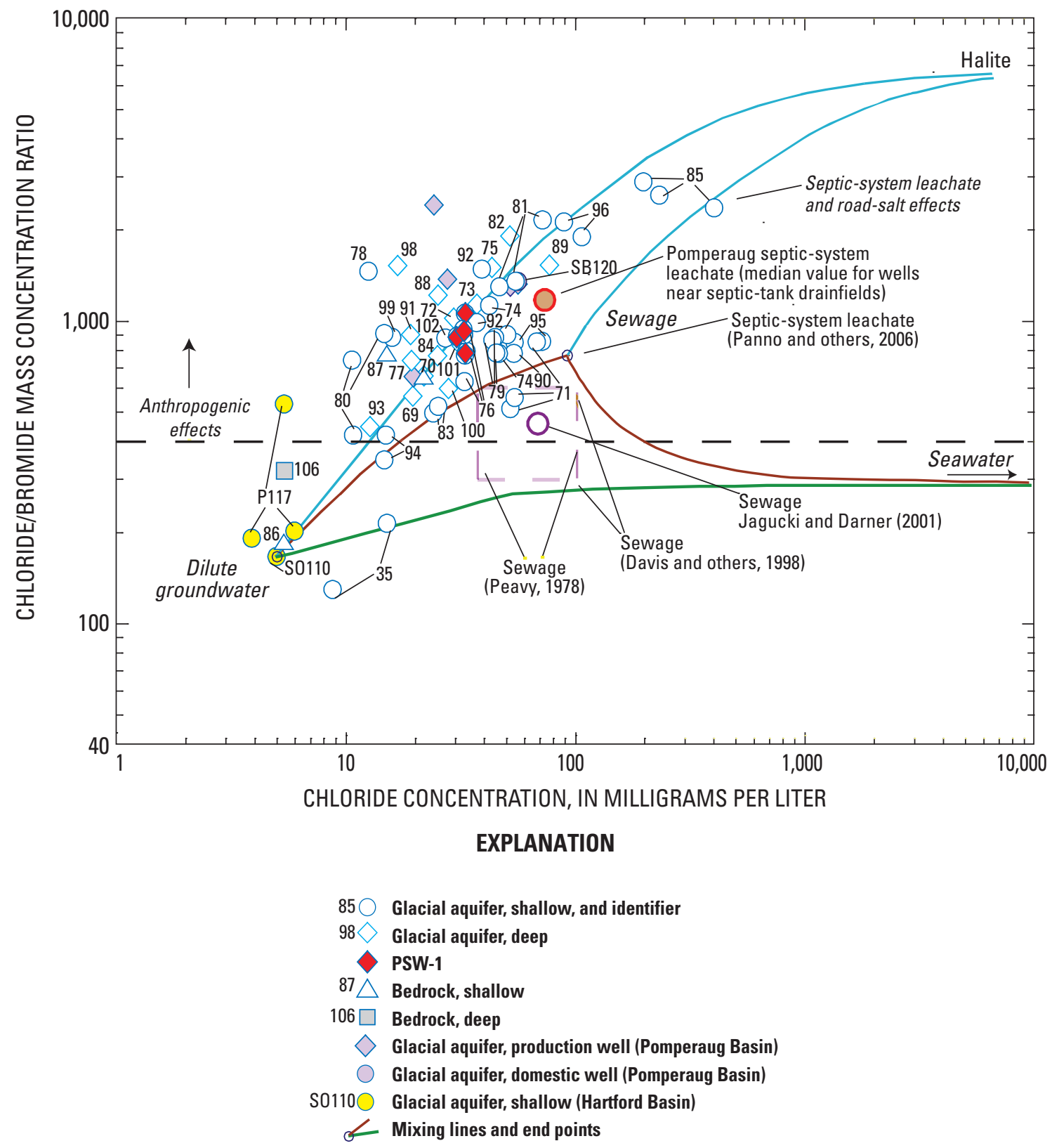

Figure 16. Concentrations of chloride as a function of chloride:bromide mass concentration ratios in samples collected in the Woodbury study area, Connecticut, and in other studies, together with mixing lines between designated end points, dilute groundwater, halite, sewage, and seawater. 
Table 10. Summary of chloride:bromide mass ratios and concentrations of selected constituents related to road salt (halite) and septic-system leachate in samples from previous studies, and groundwater samples from selected wells in the Woodbury study area and elsewhere in the Pomperaug Basin, Connecticut.

[Concentrations in milligrams per liter; $\mathrm{Na}^{+}$, sodium; $\mathrm{Ca}_{2}^{+}$, calcium; $\mathrm{SO}_{4}{ }^{2-}$, sulfate; $\mathrm{Cl}^{-}$, chloride; $\mathrm{Br}^{-}$, bromide; $\mathrm{NO}_{3}^{-}+\mathrm{NO}_{2}^{-}$, nitrate plus nitrite; $\mathrm{NH}_{4}^{+}$, ammonia; $\mathrm{PO}_{4}{ }^{3-}$, orthophosphate; $\mathrm{B}$, boron; specific conductance in microsiemens per centimeter at 25 degrees Celsius; DOC, dissolved organic carbon; DO, dissolved oxygen; $\mathrm{HCO}_{3}$, bicarbonate; --, indicates data not available; E, estimated value below minimum reporting level; NA, not applicable; $\sim$, approximately; <, less than; samples within shaded area used to calculate median for wells with septic-system leachate influence.]

\begin{tabular}{|c|c|c|c|c|c|}
\hline References & $\mathbf{N a}^{+}$ & $\mathrm{Ca}_{2}^{+}$ & $\mathrm{SO}_{4}^{2-}$ & $\mathrm{Cl}^{-}$ & $\mathrm{Br}^{-}$ \\
\hline \multicolumn{6}{|l|}{ Dilute groundwater } \\
\hline${ }^{1} \mathrm{SO} 110 ; 10 / 6 / 05$ & -- & -- & -- & 5 & 0.03 \\
\hline \multicolumn{6}{|l|}{ Sewage } \\
\hline Davis and others, 1998 (assembled for U.S., England) & -- & -- & -- & NA & NA \\
\hline Vengosh and Pankrotov, 1998 (Israel) & -- & -- & -- & $260-396$ & $0.4-0.9$ \\
\hline Thomas, 2000; Jagucki and Darner, 2001 & -- & -- & -- & 69 & NA \\
\hline Panno and others, 2006 (midwestern U.S.) & $45-2,720$ & -- & -- & 91 & 0.1183 \\
\hline $\begin{array}{l}\text { Average of median values for wells affected by Pomperaug septic-system leachate, } \\
(\text { WY } 85,89,90,95)\end{array}$ & -- & -- & -- & 113 & 0.060 \\
\hline $\begin{array}{l}\text { Median values for wells affected by Pomperaug septic-system leachate } \\
\text { (WY85,89,90,95) }\end{array}$ & -- & -- & -- & 62.7 & 0.053 \\
\hline Endpoint value for wells affected by Pomperaug septic-system leachate & -- & -- & -- & 81.5 & NA \\
\hline Behl and others, 1987 & -- & -- & -- & NA & NA \\
\hline Peavy, 1978 & -- & -- & -- & $37-101$ & NA \\
\hline \multicolumn{6}{|l|}{ Road salt/halite } \\
\hline Granato, 1996; analysis of road salt & -- & -- & -- & 10,000 & 1.5 \\
\hline Granato, 1996; highway runoff & -- & -- & -- & 80,000 & -- \\
\hline Granato, 1996; first flush winter storm & -- & -- & -- & 17,000 & -- \\
\hline Davis and others, 1998 & -- & -- & -- & -- & -- \\
\hline Schoonen and others, 1995; analysis of Suffolk County, New York, road salt & -- & -- & -- & $\sim 10,000$ & $\sim 1.76$ \\
\hline \multicolumn{6}{|l|}{ Seawater } \\
\hline Davis and others, 1998 & -- & -- & -- & $19,000-20,000$ & -- \\
\hline Hem, 1992 & -- & -- & -- & 19,000 & 65 \\
\hline Krauskopf, 1979 & 10,770 & -- & -- & 18,800 & 67 \\
\hline \multicolumn{6}{|c|}{ Atmospheric deposition } \\
\hline Davis and others, 1998; lower & -- & -- & -- & -- & -- \\
\hline Davis and others, 1998; upper & -- & -- & -- & -- & -- \\
\hline \multicolumn{6}{|c|}{ Pomperaug Basin wells with probable effects of septic-system leachate } \\
\hline WY71; 12/22/2003 & 50 & 22 & 16 & 55 & 0.096 \\
\hline WY71; 7/27/2004 & 52 & 36 & 13 & 68 & 0.078 \\
\hline WY71; 1/7/2005 & 51 & 31 & 13 & 52 & 0.10 \\
\hline WY71; 5/18/2005 & 56 & 46 & 9.7 & 120 & 0.17 \\
\hline WY73; 2/17/2003 & 27 & 23 & 12 & 37 & 0.032 \\
\hline WY74; 11/6/2003 & 32 & 27 & 13 & 42 & 0.037 \\
\hline WY74; 7/28/2004 & 30 & 31 & 11 & 50 & 0.055 \\
\hline
\end{tabular}


Table 10. Summary of chloride:bromide mass ratios and concentrations of selected constituents related to road salt (halite) and septic-system leachate in samples from previous studies, and groundwater samples from selected wells in the Woodbury study area and elsewhere in the Pomperaug Basin, Connecticut.-Continued

[Concentrations in milligrams per liter; $\mathrm{Na}^{+}$, sodium; $\mathrm{Ca}_{2}{ }^{+}$, calcium; $\mathrm{SO}_{4}{ }^{2-}$, sulfate; $\mathrm{Cl}^{-}$, chloride; $\mathrm{Br}^{-}$, bromide; $\mathrm{NO}_{3}{ }^{-}+\mathrm{NO}_{2}^{-}$, nitrate plus nitrite; $\mathrm{NH}_{4}^{+}$, ammonia; $\mathrm{PO}_{4}{ }^{3-}$, orthophosphate; $\mathrm{B}$, boron; specific conductance in microsiemens per centimeter at 25 degrees Celsius; DOC, dissolved organic carbon; DO, dissolved oxygen; $\mathrm{HCO}_{3}^{-}$, bicarbonate; --, indicates data not available; E, estimated value below minimum reporting level; NA, not applicable; $\sim$, approximately; $<$, less than;samples within shaded area used to calculate median for wells with septic-system leachate influence.]

\begin{tabular}{|c|c|c|c|c|c|c|c|c|c|}
\hline $\begin{array}{c}\mathrm{Cl}: \mathrm{Br} \\
\text { mass } \\
\text { ratio }\end{array}$ & $\begin{array}{l}\mathrm{NO}_{3}^{-}+\mathrm{NO}_{2}^{-}, \\
\quad \text { as N }\end{array}$ & $\begin{array}{l}\mathrm{NH}_{4}^{+}, \\
\text {as } \mathbf{N}\end{array}$ & $\mathrm{PO}_{4}{ }^{3-}$, as $\mathrm{P}$ & B & $\begin{array}{c}\text { Specific } \\
\text { conductance }\end{array}$ & DOC & DO & $\mathrm{HCO}_{3}^{-}$ & $\begin{array}{c}\text { Probable } \\
\text { organic } \\
\text { carbon } \\
\text { source }\end{array}$ \\
\hline \multicolumn{10}{|c|}{ Dilute groundwater } \\
\hline 167.0 & -- & -- & -- & -- & -- & -- & -- & -- & -- \\
\hline \multicolumn{10}{|c|}{ Sewage } \\
\hline $300-600$ & -- & -- & -- & -- & -- & -- & -- & -- & -- \\
\hline $410-873$ & -- & -- & -- & -- & -- & -- & -- & -- & -- \\
\hline 450 & -- & -- & -- & -- & -- & -- & -- & -- & -- \\
\hline 769 & -- & -- & -- & -- & -- & -- & -- & -- & -- \\
\hline 997 & -- & -- & -- & -- & -- & -- & -- & -- & -- \\
\hline 1,200 & -- & -- & -- & -- & -- & -- & -- & -- & -- \\
\hline 873 & -- & -- & -- & -- & -- & -- & -- & -- & -- \\
\hline $275-531$ & -- & -- & -- & -- & -- & -- & -- & -- & -- \\
\hline NA & -- & -- & -- & -- & -- & -- & -- & -- & -- \\
\hline \multicolumn{10}{|c|}{ Road salt/halite } \\
\hline 6,667 & -- & -- & -- & -- & -- & -- & -- & -- & -- \\
\hline 3,300 & -- & -- & -- & -- & -- & -- & -- & -- & -- \\
\hline 58,621 & -- & -- & -- & -- & -- & -- & -- & -- & -- \\
\hline $1,000-10,000$ & -- & -- & -- & -- & -- & -- & -- & -- & -- \\
\hline 5,690 & -- & -- & -- & -- & -- & -- & -- & -- & -- \\
\hline \multicolumn{10}{|c|}{ Seawater } \\
\hline $288-292$ & -- & -- & -- & -- & -- & -- & -- & -- & -- \\
\hline 292 & -- & -- & -- & -- & -- & -- & -- & -- & -- \\
\hline 281 & -- & -- & -- & -- & -- & -- & -- & -- & -- \\
\hline \multicolumn{10}{|c|}{ Atmospheric deposition } \\
\hline 50-120 (inland) & -- & -- & -- & -- & -- & -- & -- & -- & -- \\
\hline $130-180$ (near coast) & -- & -- & -- & -- & -- & -- & -- & -- & -- \\
\hline \multicolumn{10}{|c|}{ Pomperaug Basin wells with probable effects of septic-system leachate } \\
\hline 866 & 1.1 & $<.04$ & E0.004 & 32 & 400 & 1.3 & -- & 160 & Mesozoic rocks \\
\hline 521 & 0.9 & $<.04$ & 0.017 & -- & 511 & 0.99 & 0.81 & 170 & Partly septic \\
\hline 746 & 0.7 & $<.04$ & E0.005 & -- & 461 & 1.20 & 1.5 & 130 & Partly septic \\
\hline 1,145 & 2.2 & $<.04$ & $<0.006$ & -- & 645 & 0.81 & 3.2 & 110 & Partly septic \\
\hline 1,158 & 2.1 & $<.04$ & E0.005 & 100 & 297 & 0.61 & 4.2 & 79 & Partly septic \\
\hline 1,145 & 1.9 & $<.04$ & 0.007 & 120 & 344 & 0.67 & 5.8 & 110 & Partly septic \\
\hline 921 & 1.6 & $<.04$ & 0.026 & -- & 385 & 0.67 & 5.9 & 120 & Partly septic \\
\hline
\end{tabular}


Table 10. Summary of chloride:bromide mass ratios and concentrations of selected constituents related to road salt (halite) and septic-system leachate in samples from previous studies, and groundwater samples from selected wells in the Woodbury study area and elsewhere in the Pomperaug Basin, Connecticut. —Continued

[Concentrations in milligrams per liter; $\mathrm{Na}^{+}$, sodium; $\mathrm{Ca}_{2}^{+}$, calcium; $\mathrm{SO}_{4}{ }^{2-}$, sulfate; $\mathrm{Cl}^{-}$, chloride; $\mathrm{Br}^{-}$, bromide; $\mathrm{NO}_{3}^{-}+\mathrm{NO}_{2}^{-}$, nitrate plus nitrite; $\mathrm{NH}_{4}^{+}$, ammonia; $\mathrm{PO}_{4}{ }^{3-}$, orthophosphate; $\mathrm{B}$, boron; specific conductance in microsiemens per centimeter at 25 degrees Celsius; DOC, dissolved organic carbon; DO, dissolved oxygen; $\mathrm{HCO}_{3}$, bicarbonate; --, indicates data not available; E, estimated value below minimum reporting level; NA, not applicable; $\sim$, approximately; <, less than; samples within shaded area used to calculate median for wells with septic-system leachate influence.]

\begin{tabular}{|c|c|c|c|c|c|c|}
\hline \multicolumn{2}{|c|}{ References } & \multirow{2}{*}{$\begin{array}{c}\mathbf{N a}^{+} \\
30\end{array}$} & \multirow{2}{*}{$\begin{array}{c}\mathrm{Ca}_{2}^{+} \\
33\end{array}$} & \multirow{2}{*}{$\begin{array}{c}\mathbf{S O}_{4}^{2-} \\
11\end{array}$} & \multirow{2}{*}{$\begin{array}{l}\mathrm{Cl}^{-} \\
47\end{array}$} & \multirow{2}{*}{$\begin{array}{c}\mathrm{Br}^{-} \\
0.059\end{array}$} \\
\hline WY74; 1/10/2005 & & & & & & \\
\hline WY74; 6/15/2005 & & 25 & 30 & 11 & 37 & -- \\
\hline WY76; 11/12/2003 & & 22 & 20 & 11 & 32 & 0.034 \\
\hline WY76; 7/26/2004 & & 21 & 23 & 13 & 34 & 0.042 \\
\hline WY76; 1/4/2005 & & 25 & 18 & 14 & 33 & 0.051 \\
\hline WY76; 6/14/2005 & & 18 & 17 & 10 & 29 & 0.076 \\
\hline $\mathrm{SB} 120^{2} ; 11 / 15 / 2002$ & & 38 & 37 & 14 & 56 & 0.041 \\
\hline WY85; 11/19/2003 & & 65 & 128 & 8.7 & 400 & 0.167 \\
\hline WY85; 8/10/2004 & & 45 & 68 & 8.6 & 200 & 0.069 \\
\hline WY85; 2/1/2005 & & 47 & 90 & 11 & 230 & 0.088 \\
\hline WY85; 6/16/2005 & & 65 & 125 & 9.7 & 380 & -- \\
\hline WY89; 11/2/2004 & & 16 & 62 & 9.7 & 77 & 0.050 \\
\hline WY90; 11/9/2004 & & 0.081 & 103 & 7.7 & 54 & 0.069 \\
\hline WY90; 5/26/2005 & & 0.095 & 85 & 11 & 63 & -- \\
\hline WY95; 8/2/2004 & & 40 & 27 & 14 & 71 & 0.082 \\
\hline WY95; 2/1/2005 & & 33 & 25 & 11 & 54 & 0.063 \\
\hline \multirow[t]{4}{*}{ WY95; 6/16/2005 } & & 35 & 27 & 12 & 67 & -- \\
\hline & Pomperaug Basin Median & -- & -- & -- & 72 & 0.069 \\
\hline & Range-high & -- & -- & -- & 377 & 0.55 \\
\hline & Range-low & -- & -- & -- & 43 & 0.049 \\
\hline
\end{tabular}

${ }^{1}$ Glacial well in forested, undeveloped land, Hartford Basin.

${ }^{2}$ Glacial, domestic well (major aquifer study) in Pomperaug Basin. 
Table 10. Summary of chloride:bromide mass ratios and concentrations of selected constituents related to road salt (halite) and septic-system leachate in samples from previous studies, and groundwater samples from selected wells in the Woodbury study area and elsewhere in the Pomperaug Basin, Connecticut.-Continued

[Concentrations in milligrams per liter; $\mathrm{Na}^{+}$, sodium; $\mathrm{Ca}_{2}{ }^{+}$, calcium; $\mathrm{SO}_{4}{ }^{2-}$, sulfate; $\mathrm{Cl}^{-}$, chloride; $\mathrm{Br}^{-}$, bromide; $\mathrm{NO}_{3}{ }^{-}+\mathrm{NO}_{2}^{-}$, nitrate plus nitrite; $\mathrm{NH}_{4}^{+}$, ammonia; $\mathrm{PO}_{4}{ }^{3-}$, orthophosphate; $\mathrm{B}$, boron; specific conductance in microsiemens per centimeter at 25 degrees Celsius; DOC, dissolved organic carbon; DO, dissolved oxygen; $\mathrm{HCO}_{3}^{-}$, bicarbonate; --, indicates data not available; E, estimated value below minimum reporting level; NA, not applicable; $\sim$, approximately; <, less than;samples within shaded area used to calculate median for wells with septic-system leachate influence.]

\begin{tabular}{|c|c|c|c|c|c|c|c|c|c|}
\hline $\begin{array}{l}\mathrm{Cl}: \mathrm{Br} \\
\text { mass } \\
\text { ratio }\end{array}$ & $\begin{array}{c}\mathrm{NO}_{3}{ }^{-}+\mathrm{NO}_{2}^{-} \\
\text {as } \mathbf{N}\end{array}$ & $\begin{array}{l}\mathrm{NH}_{4}^{+}, \\
\text {as N }\end{array}$ & $\mathrm{PO}_{4}^{3-}$, as $\mathrm{P}$ & B & $\begin{array}{c}\text { Specific } \\
\text { conductance }\end{array}$ & DOC & DO & $\mathrm{HCO}_{3}^{-}$ & $\begin{array}{c}\text { Probable } \\
\text { organic } \\
\text { carbon } \\
\text { source }\end{array}$ \\
\hline 794 & 1.1 & $<.04$ & 0.009 & -- & 388 & 0.76 & 5.1 & 130 & Partly septic \\
\hline-- & 1.7 & $<.04$ & 0.007 & -- & 344 & 0.60 & 6.2 & 120 & Partly septic \\
\hline 957 & 3.8 & $<.04$ & 0.007 & 76 & 265 & 0.51 & 4.8 & 61 & Partly septic \\
\hline 813 & 2.5 & $<.04$ & 0.022 & -- & 274 & 0.57 & 2 & 61 & Partly septic \\
\hline 644 & 3.4 & $<.04$ & 0.008 & -- & 272 & 0.66 & 3.1 & 49 & Partly septic \\
\hline 382 & 2.5 & $<.04$ & 0.006 & -- & 240 & 0.46 & 4.2 & 59 & Partly septic \\
\hline 1,366 & 11 & $<0.04$ & $<.02$ & 49 & 660 & 0.8 & 1.3 & 120 & Septic \\
\hline 2,395 & $<.06$ & $<.04$ & E0.003 & 34 & 1452 & 7.8 & 0.6 & 89 & Septic \\
\hline 2,920 & 14 & 1.1 & 0.013 & -- & 906 & 89 & 0.66 & 65 & Septic \\
\hline 2,614 & 12 & 2 & $<0.006$ & -- & 1025 & 3.0 & 0.5 & 76 & Septic \\
\hline-- & 19 & 4.2 & $<0.006$ & -- & 1529 & 2.0 & 2.59 & 66 & Septic \\
\hline 1,525 & 6.7 & 0.058 & 0.016 & 51 & 570 & -- & 8.0 & 140 & Septic \\
\hline 776 & 17.4 & 0.05 & 0.012 & -- & 751 & 1.2 & 1.6 & 170 & Septic \\
\hline-- & 9.4 & 0.25 & E0.004 & 160 & 646 & 0.60 & 8.8 & 220 & Septic \\
\hline 872 & 0.26 & E0.028 & 0.018 & -- & 417 & 1.8 & 0.57 & 93 & Partly septic \\
\hline 865 & 1.4 & $<0.04$ & E0.005 & -- & 349 & 1.1 & 0.14 & 83 & Partly septic \\
\hline-- & 1.6 & $<0.04$ & 0.008 & -- & 400 & 0.72 & 1.22 & 81 & Partly septic \\
\hline 1,197 & 10 & & 0.008 & -- & 634 & 1.1 & 2.9 & 112 & -- \\
\hline 1,525 & -- & -- & -- & -- & -- & -- & -- & -- & -- \\
\hline 363 & -- & -- & -- & -- & -- & -- & -- & -- & -- \\
\hline
\end{tabular}


drainfield for a retirement home; a groundwater sample had a Cl:Br ratio of 1,400 and $\mathrm{Cl}^{-}$concentration of $56 \mathrm{mg} / \mathrm{L}$, similar to those in samples from the Woodbury study area. The $\mathrm{Cl}^{-}$concentrations and $\mathrm{Cl}: \mathrm{Br}$ ratios for samples taken from these wells, in addition to samples from wells that are near septic-tank drainfields (WY71, WY74, WY76, and WY96), were used to define the areas on the graph likely affected by septic-system leachate (fig. 16). Values for several samples from other wells in the study area also plot within the area of the graph showing wells affected by septic-system leachate, including WY81, WY83, WY94, WY100, and PSW-1. The Cl:Br ratios associated with domestic sewage reported elsewhere were 275 to 531 (Behl and others, 1987) and 300 to 600 (Davis and others, 1998) (table 10). $\mathrm{Cl}^{-}$concentrations in septic systems and adjacent soils in Montana ranged from $37 \mathrm{mg} / \mathrm{L}$ to $101 \mathrm{mg} / \mathrm{L}$ (Peavy, 1978). Values for community supply wells in the Pomperaug River watershed, including PSW-1, generally plot along the dilute groundwater-halite line (fig. 16).

Concentrations of $\mathrm{NO}_{3}^{-}+\mathrm{NO}_{2}^{-}$in groundwater can be derived from several sources, including microbial decay of organic matter in soils, animal waste, septic-system leachate, synthetic fertilizers, and rainfall. $\mathrm{NO}_{3}^{-}+\mathrm{NO}_{2}^{-}$concentrations ranged from less than the MRLs in water samples with reducing redox characteristics to $19 \mathrm{mg} / \mathrm{L}$ as $\mathrm{N}$ for a well that is immediately downgradient from a septic-tank drainfield (table 10). Concentrations of $\mathrm{NO}_{2}^{-}$were less than the MRL of $0.008 \mathrm{mg} / \mathrm{L}$ in all but two samples; therefore, $\mathrm{NO}_{3}^{-}+\mathrm{NO}_{2}^{-}$will hereafter be referred to as simply " $\mathrm{NO}_{3}{ }^{-}$". The median concentration of $\mathrm{NO}_{3}^{-}$for wells in the study area was $1.3 \mathrm{mg} / \mathrm{L}$ as $\mathrm{N}$, but values varied considerably depending on the presence of anthropogenic $\mathrm{N}$ sources and redox conditions. Urban septic-system leachate and lawn fertilizer are the major sources of $\mathrm{NO}_{3}^{-}$in the study area and significantly affect shallow groundwater quality (figs. 17 and 18). A graph of $\mathrm{Cl}: \mathrm{Br}$ ratios and $\mathrm{NO}_{3}{ }^{-}$concentrations shows that samples from wells adjacent to septic-tank drainfields and (or) the commercial area have high $\mathrm{Cl}: \mathrm{Br}$ concentration ratios, and $\mathrm{NO}_{3}^{-}$concentrations generally are high but include concentrations less than the MRL (fig. 17).

The presence of DOC concentrations that are greater than background appears to result in reduction of $\mathrm{NO}_{3}{ }^{-}$to $\mathrm{N}_{2}$ (denitrification), as well as reduction of other electron acceptors $\mathrm{O}_{2}, \mathrm{Mn}^{4+}, \mathrm{Fe}^{3+}$, and $\mathrm{SO}_{4}{ }^{2-}$. The classification of wells based on water chemistry indicators and proximal natural or anthropogenic sources of DOC, which is described in a following section, "Redox Conditions and DOC," is illustrated in figures 17 and 18 by varying colors of symbol outlines

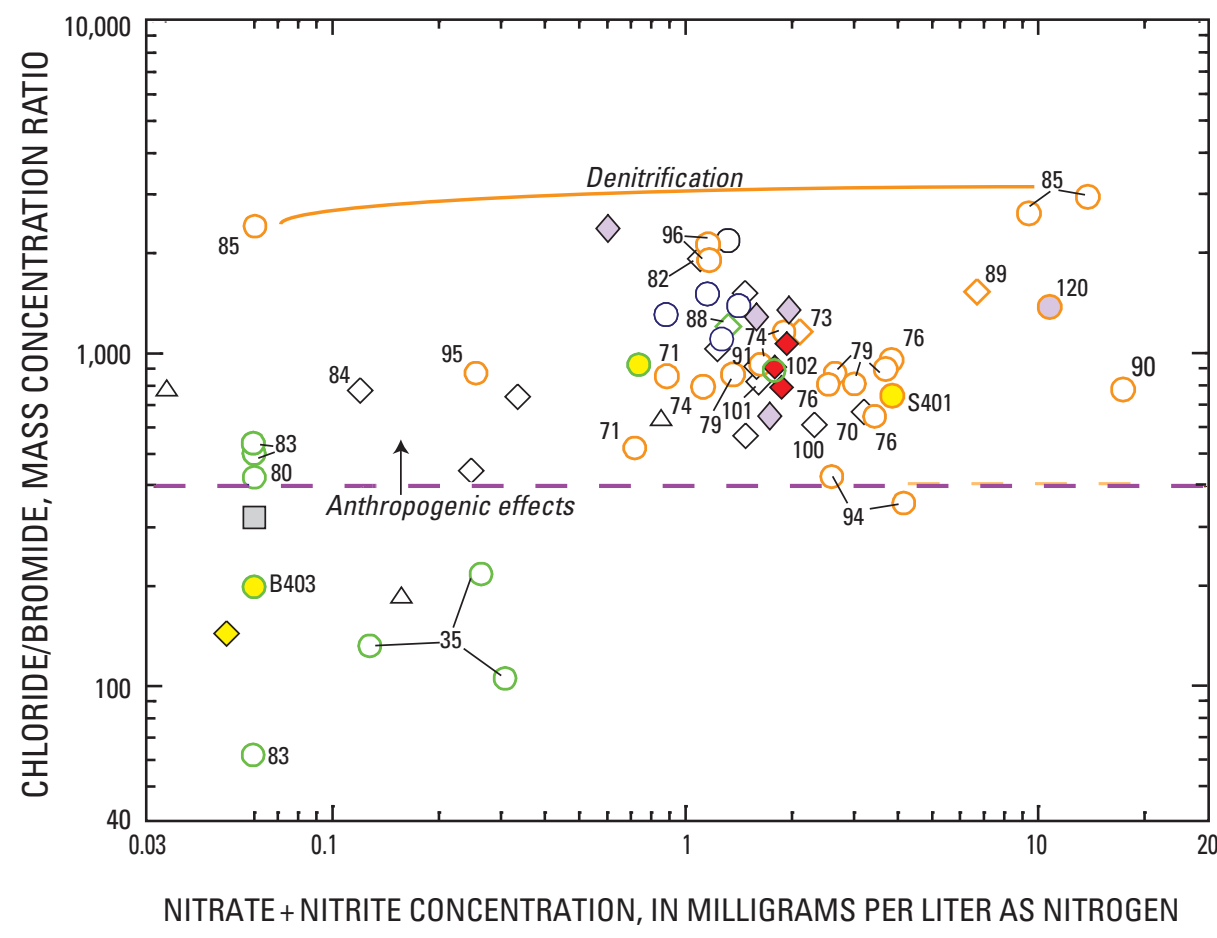

\section{EXPLANATION}

$95 \bigcirc$ Glacial aquifer, shallow, and identifier

$77 \diamond$ Glacial aquifer, deep

PSW-1

${ }^{87} \triangle$ Bedrock, shallow

$106 \square$ Bedrock, deep

$\diamond$ Glacial aquifer, production well (Pomperaug Basin)

Glacial deposits, domestic well (Pomperaug Basin)

Glacial aquifer, shallow (Hartford Basin)

$\diamond$ Glacial aquifer, deep (Hartford Basin) Symbol outline color:

Low DOC, natural organic matter source

High DOC, natural organic matter source

High DOC, septic-system leachate source

Figure 17. Concentrations of nitrate plus nitrite as a function of chloride/bromide mass concentration ratios in groundwater samples in the Woodbury study area, and from selected wells elsewhere in the Pomperaug and Hartford Basins, Connecticut. Symbols are color coded for the estimated relative dissolved organic carbon (DOC) source and strength. 

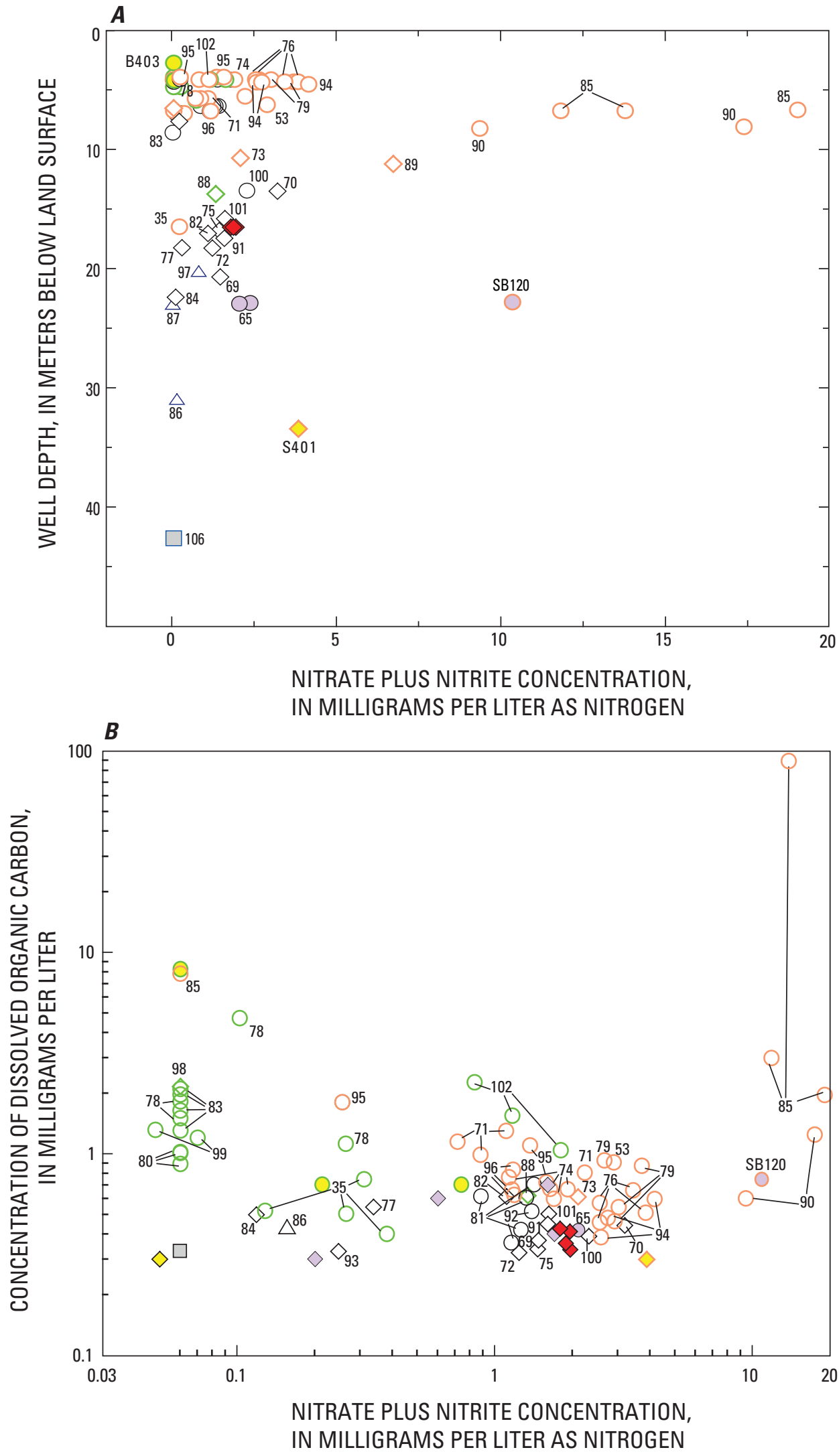

\section{EXPLANATION}

$81 \bigcirc$ Glacial aquifer, shallow, and identifier

$\diamond$ Glacial aquifer, deep

PSW-1

86 $\triangle$ Bedrock, shallow

$\square$ Bedrock, deep

$\bigcirc$ Glacial aquifer, domestic well (Pomperaug Basin)

$\diamond$ Glacial aquifer, production well (Pomperaug Basin)

Glacial aquifer, shallow (Hartford Basin)

$\diamond$ Glacial aquifer, deep (Hartford Basin)

Symbol outline color:

Low DOC, natural organic-matter source

High DOC, natural organic-matter source

High DOC, septic-system leachate source

Figure 18. Concentration of nitrate plus nitrite as a function of $(A)$ well depth, and $(B)$ concentration of dissolved organic carbon, in groundwater samples from wells in the Woodbury study area, and from selected wells elsewhere in the Pomperaug and Hartford Basins, Connecticut. Symbols are color coded for the estimated relative dissolved organic carbon (DOC) source and strength. 
for sample data points. For wells that are near septic-tank drainfields, concentrations of $\mathrm{NO}_{3}^{-}$(median $10 \mathrm{mg} / \mathrm{L}$ as N) and DOC (median of $1 \mathrm{mg} / \mathrm{L}$ ) generally were higher than those of background wells and are defined herein as "High DOC, septic-system leachate source." Samples from most wells had low concentrations of $\mathrm{NO}_{3}^{-}$and DOC; these wells are defined herein as "Low DOC, natural organic matter source." Groundwater that appeared to be naturally reducing as a result of high DOC from riparian zones, buried wetland deposits, or sediments, likely derived from the organic-rich Cass Formation had lower $\mathrm{NO}_{3}^{-}$concentrations than the median, apparently because of denitrification; these wells are defined herein as "High DOC, natural organic matter source" (fig. 18B).

$\mathrm{NO}_{3}{ }^{-}$concentrations in the four wells downgradient from septic-tank drainfields ranged from less than the MRL to $19 \mathrm{mg} / \mathrm{L}$ as N, with a median concentration of $10 \mathrm{mg} / \mathrm{L}$ as N. Well WY85, which is downgradient from a drainfield, generally had high $\mathrm{NO}_{3}^{-}$concentrations (as much as $19 \mathrm{mg} / \mathrm{L}$ as $\mathrm{N}$ ), although the $\mathrm{NO}_{3}^{-}$concentration was less than the MRL of $0.06 \mathrm{mg} / \mathrm{L}$ in the first sample collected, despite high DOC concentrations (figs. 17 and 18B); the high $\mathrm{NO}_{3}{ }^{-}$concentration indicates the likely presence of a denitrifying zone near the screen. The DOC in septic-system leachate is attenuated, and $\mathrm{NH}_{4}^{+}$is oxidized to $\mathrm{NO}_{3}^{-}$, in the unsaturated zone (Robertson and others, 1991; Harmon and others, 1996). The presence of high concentrations of DOC ( $2 \mathrm{mg} / \mathrm{L}$ on June 16,2005 , to $89 \mathrm{mg} / \mathrm{L}$ on August 10, 2004), together with widely varying $\mathrm{NO}_{3}^{-}$concentrations, in samples from WY85 collected on November 19, 2003 and August 10, 2004 indicate that DOC, likely from septic-tank drainfields, was not oxidized before entering the water table and, therefore, apparently provided an electron donor for denitrification in the November 19, 2003 sample. The unsaturated zone sediments below the septictank drainfield may have been overloaded with septic-system leachate from a system overload or failure, resulting in high concentrations of nitrate in subsequent samples.

Concentrations of $\mathrm{NH}_{4}^{+}$were less than the MRL at most sites, but were as high as $4.2 \mathrm{mg} / \mathrm{L}$ as $\mathrm{N}$ at wells affected by septic-system leachate; the concentrations also were measurable in parts of the aquifer that contain naturally occurring organic matter in sediment or riparian zones and that have reducing characteristics (table 7). $\mathrm{PO}_{4}^{3-}$ concentrations were low, with a median of $0.006 \mathrm{mg} / \mathrm{L}$, but those wells with septic-system leachate effects had a median of $0.008 \mathrm{mg} / \mathrm{L}$ as P (table 7).

\section{Temporal Variations in Water Chemistry}

Temperature, DOC concentrations, redox conditions, and concentrations of contaminants from road salt and septictank drainfields changed temporally in shallow groundwater. These changes reflect the seasonal variability in groundwater recharge and decomposition of leaves and other organic debris in riparian zones, as well as variability in anthropogenic sources, such as road salt and septic-system leachate. During the study period, median groundwater temperatures were about $12.3^{\circ} \mathrm{C}$ in shallow wells, $11.6^{\circ} \mathrm{C}$ in intermediate and deep wells, and $9.6^{\circ} \mathrm{C}$ in bedrock wells and upland till wells. Deep wells that were sampled periodically had temperature ranges of only a few degrees Celsius.

Variations in groundwater temperature were greatest in shallow wells that have more rapid recharge, particularly near losing streams. For shallow wells that were sampled several times during different seasons, groundwater temperatures differed most near South Brook, including variations of $8.4^{\circ} \mathrm{C}$ in $\mathrm{WY} 80,13.5^{\circ} \mathrm{C}$ in WY78, and $9.9^{\circ} \mathrm{C}$ in WY99 (table 7). The water chemistry in samples from WY78 also varied seasonally; specific conductance ranged from 104 to $764 \mu \mathrm{S} / \mathrm{cm}$, probably resulting from road salt (halite) runoff during winter months, and redox conditions varied from oxic to $\mathrm{SO}_{4}{ }^{2-}$ reducing, probably resulting from the decay of natural organic matter in nearby stream sediments during the summer and fall and the subsequently high concentrations of DOC ( 1.1 to $5.7 \mathrm{mg} / \mathrm{L})$ in water samples. Groundwater temperatures varied by about $7^{\circ} \mathrm{C}$ in WY35, adjacent to the Pomperaug River; stable-isotope ratios indicate that the effects on the water chemistry in samples from WY35 may be caused by leakage from the river and adjacent quarry ponds. Groundwater temperatures varied by $11^{\circ} \mathrm{C}$ at well WY81, which is situated on a slope, and the variation probably results from rapid recharge, as supported by the quick response of water levels to rainfall events. The large temporal variations in redox chemistry and concentrations of DOC and nitrate in groundwater samples from WY85 could have resulted from an exceedance of capacity of a nearby septic-tank drainfield, as discussed in the previous section.

Long-term variation in water chemistry was difficult to identify because of the lack of chemical data, although some long-term data are available for PSW-1. A sample collected from PSW-1 in 1979 had major ion chemistry similar to that of deep glacial wells, but samples obtained from 2002 to 2005 show a shift in ion ratios and appear to reflect several shallow sources of contamination, particularly road salt and septicsystem leachate (table 7). The increase in concentrations of $\mathrm{Cl}^{-}, \mathrm{Na}^{+}, \mathrm{HCO}_{3}^{-}$, and other constituents could result from an increase in population and a concomitant increase in contaminant sources, particularly septic-tank drainfields (table 7; figs. 11 and 18).

\section{Redox Conditions and DOC}

Redox reactions affect many chemical processes in aquifers, including the speciation and mobility of naturally occurring elements, such as Fe, Mn, S, As, and U, and the transformation of anthropogenic compounds, such as $\mathrm{NO}_{3}^{-}$, chloroform, and PCE. Redox conditions proceed along a well-documented sequence of Terminal Electron Acceptor Processes (TEAP), in which a single TEAP typically dominates at a particular time and aquifer location (Chapelle and others, 1995). The predominant TEAPs, from more oxidizing to reducing are $\mathrm{O}_{2}$ - reducing (also referred to as 
oxic in this report), $\mathrm{NO}_{3}{ }_{3}^{-}$reducing, Mn-reducing, Fe-reducing, $\mathrm{SO}_{4}{ }^{2-}$ reducing, and methanic (containing $\mathrm{CH}_{4}$ ). A redox classification scheme developed for the regional-scale TANC studies, as described by Paschke and others (2007) and presented in Appendix 4, uses various chemical indicator species to classify redox conditions in each groundwater sample; however, the present study has modified this scheme based on data that are available for hydrogen sulfide and methane (table 7). In several instances, conflicting or overlapping indicators of redox conditions occur and are related to mixtures of water with different redox indicators but also may indicate disequilibrium between redox indicators (table 7).

Groundwater in the glacial aquifer generally is oxic, but commonly contains indicators of $\mathrm{NO}_{3}^{-}, \mathrm{Mn}-, \mathrm{Fe}-$, or $\mathrm{SO}_{4}{ }^{2-}$ reducing, or significantly increased groundwater concentrations of $\mathrm{Cl}^{-}$and other major ions (table 7), as well as trace elements such as B and Mn (fig. 21B). B is present in domestic sewage as a residue of laundry detergents and, therefore, can be an indicator of septic-system leachate in the Woodbury study area.

\section{Naturally Occurring Constituents of Concern}

Naturally occurring constituents of concern in this study area include trace elements, such as $\mathrm{As}, \mathrm{U},{ }^{222} \mathrm{Rn}$, and $\mathrm{Mn}$, as well as some major ions, including $\mathrm{Cl}^{-}$and $\mathrm{SO}_{4}{ }^{2-}$. These constituents can be mobilized from sediments and rocks by different geochemical processes, or derived from deep Mesozoic basin water that has high concentrations of total dissolved solids.

Concentrations of dissolved As generally were low in the study area, which is typical of glacial aquifers in much of the eastern United States (Thomas, 2007). Dissolved As in groundwater is largely affected by adsorption processes, which can vary with redox conditions, $\mathrm{pH}$, competing ions, and the sorption properties of mineral surfaces. Dissolved As concentrations in the groundwater samples ranged from less than the MRL of $0.2 \mu \mathrm{g} / \mathrm{L}$ to $5.8 \mu \mathrm{g} / \mathrm{L}$, but only eight samples from the study area had concentrations at or greater than the MRL (fig. 22A). Much of the glacial deposits in the study area likely are derived from underlying basalt (fig. 7); groundwater in unaltered basalt commonly contains low As concentrations (Welch and others, 2000). Several groundwater samples that contained some of the highest dissolved As concentrations had DO concentrations less than $2 \mathrm{mg} / \mathrm{L}$ (fig. 23A), and the two samples with the highest As concentrations (WY35 and WY83) contained dissolved Fe concentrations greater than $2,500 \mu \mathrm{g} / \mathrm{L}$ (table 8 ), indicating greater As mobility under anoxic conditions. As discussed in the previous section, "Redox Conditions and DOC," the anoxic conditions were associated with concentrations of DOC, and some of the highest As (fig. 23B), Mn, and Fe concentrations (fig. 20C and D) in groundwater samples were from aquifer sediments that appear to be derived from the organic-rich rock of the Cass Formation, which underlies glacial deposits about $0.6 \mathrm{~km}$ to the north (fig. 7; table 8; Burton, 2006). It also is possible that additional subsurface faults, not shown on the geologic map, exist that have exposed the Cass Formation to the underlying glacial deposits nearer WY83 (W.C. Burton, U.S. Geological Survey, written commun., 2005). As can be mobilized by reduction of $\mathrm{As}(\mathrm{V})$, or by the reductive dissolution of ferric oxyhydroxides coupled to the oxidation of organic $\mathrm{C}$, which typically results in the subsequent mobilization of sorbed As (Stollenwerk, 2003). Other monitoring wells downgradient from WY83, including WY35, WY88, and WY53, also had As concentrations that were greater than background concentrations and may have been affected by sediments derived from the Cass Formation (fig. 22A); the locations of these wells, and their geochemical similarity, are consistent with the southward, down-valley direction by which rocks from the Cass Formation would have been transported by glacial ice. Wells S401 and F344 that appear to be screened in glacial deposits derived from the Newark Supergroup rocks in the Hartford Basin also had As concentrations greater than the MRL. Concentrations of As also were somewhat greater in bedrock wells WY86 and WY87, which are close to the eastern border fault. The concentrations of As in samples from PSW-1 were less than the MRL, although communitysupply well WY66 that is $2 \mathrm{~km}$ to the west had detectable As concentrations $(1.6 \mu \mathrm{g} / \mathrm{L})$; well WY66 also had high concentrations of $\mathrm{Mn}$ and $\mathrm{Fe}$ of $1,800 \mu \mathrm{g} / \mathrm{L}$ and $4,700 \mu \mathrm{g} / \mathrm{L}$, respectively, indicating reducing conditions (table 8) that might be caused by organic-rich sediments.

Dissolved U concentrations in groundwater samples were low, ranging from less than the MRL of $0.2 \mu \mathrm{g} / \mathrm{L}$ to $1.8 \mu \mathrm{g} / \mathrm{L}$ (table 8). Other glacial aquifers throughout the Northeast also had low U concentrations compared to glacial aquifer systems throughout the United States (Ayotte and others, 2007). U concentrations were highest in wells with low DO $(<0.8 \mathrm{mg} / \mathrm{L})$ despite the fact that $\mathrm{U}$ is more soluble under oxic conditions; this indicates that other factors likely affected $\mathrm{U}$ concentrations, such as proximity to the bedrock interface (fig. 22B), or groundwater $\mathrm{pH}$ and $\mathrm{HCO}_{3}-$ concentrations (figs. 23C and D). Under oxic conditions, $\mathrm{U}$ exists in the $6^{+}$oxidation state $[\mathrm{U}(\mathrm{VI})]$ and will form the oxycation, uranyl $\left(\mathrm{UO}_{2}^{2+}\right)$ in normal $\mathrm{pH}$ ranges of 6 to 9 . Under anoxic conditions, $\mathrm{U}(\mathrm{VI})$ generally is reduced to U(IV) and is much less mobile. The $\mathrm{U}$ concentration was below the MRL in a groundwater sample from WY83, despite the high concentration $(11 \mu \mathrm{g} / \mathrm{g})$ in a sediment extraction with 10 percent $\mathrm{HNO}_{3}$ from aquifer material adjacent to the well screen (table 5), because U typically is reduced in organic-rich horizons. The abundance of $U$ on selected ferric hydroxide grains of sediments from several sites, as determined by fission track radiography (fig. 9), is consistent with the large abundance of $U$ in the extraction of sediment from WY83, probably from the Cass Formation, relative to other aquifer core samples. Concentrations of $\mathrm{U}$ were highest in wells in crystalline (Paleozoic-age) bedrock and glacial till and generally were highest in the deepest well of each cluster, indicating that the proximity to bedrock affects the dissolved 

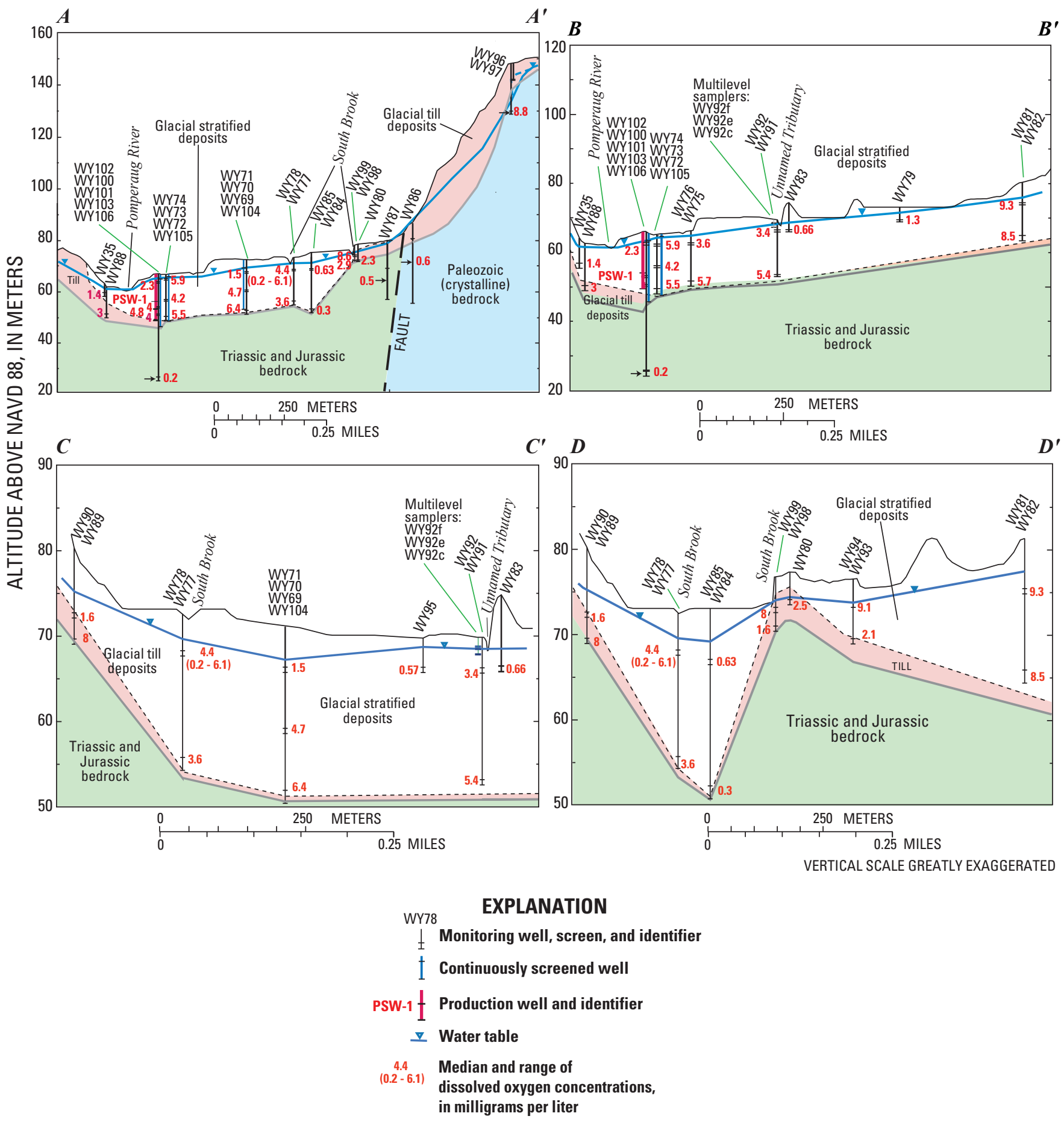

Figure 19. Hydrogeologic sections showing medians, and selected ranges, of dissolved oxygen concentrations in groundwater samples from wells in the study area, Woodbury, Connecticut. 

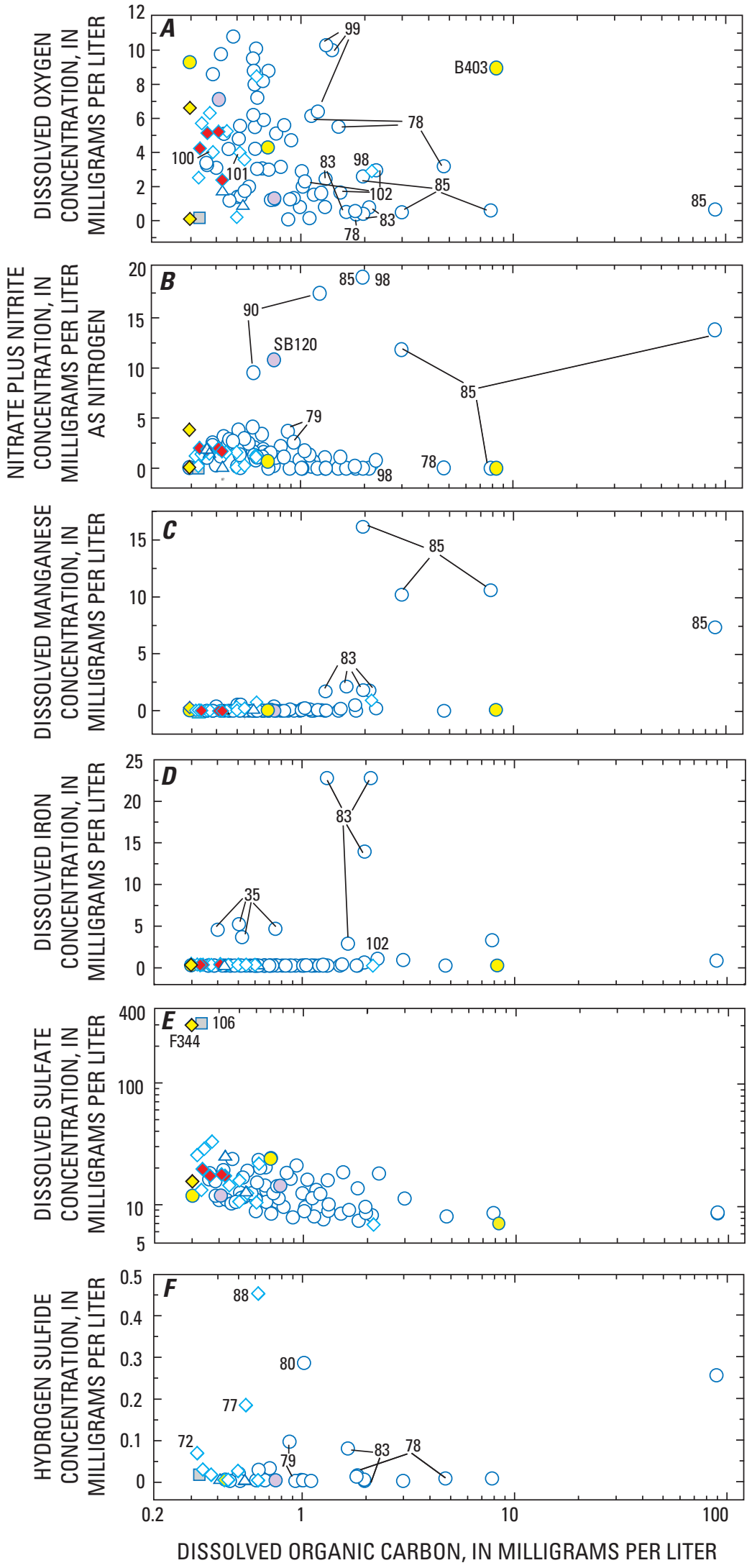

\section{EXPLANATION}

$85 \bigcirc$ Glacial aquifer, shallow, and identifier

$98 \diamond$ Glacial aquifer, deep

PSW-1

$\triangle$ Bedrock, shallow

$\square$ Bedrock, deep

B403 $O$ Glacial aquifer, shallow (Hartford Basin)

S401 $\diamond$ Glacial aquifer, deep (Hartford Basin)

SB120 O Glacial aquifer, domestic well

(Pomperaug Basin)
Figure 20. Concentrations of dissolved organic carbon (DOC) as a function of the concentration of electron acceptor indicators, including dissolved $(A)$ oxygen, $(B)$ nitrate plus nitrite, $(C)$ manganese, $(D)$ iron, $(E)$ sulfate, and (F) hydrogen sulfide, in groundwater samples from wells in the study area, Woodbury, Connecticut. 


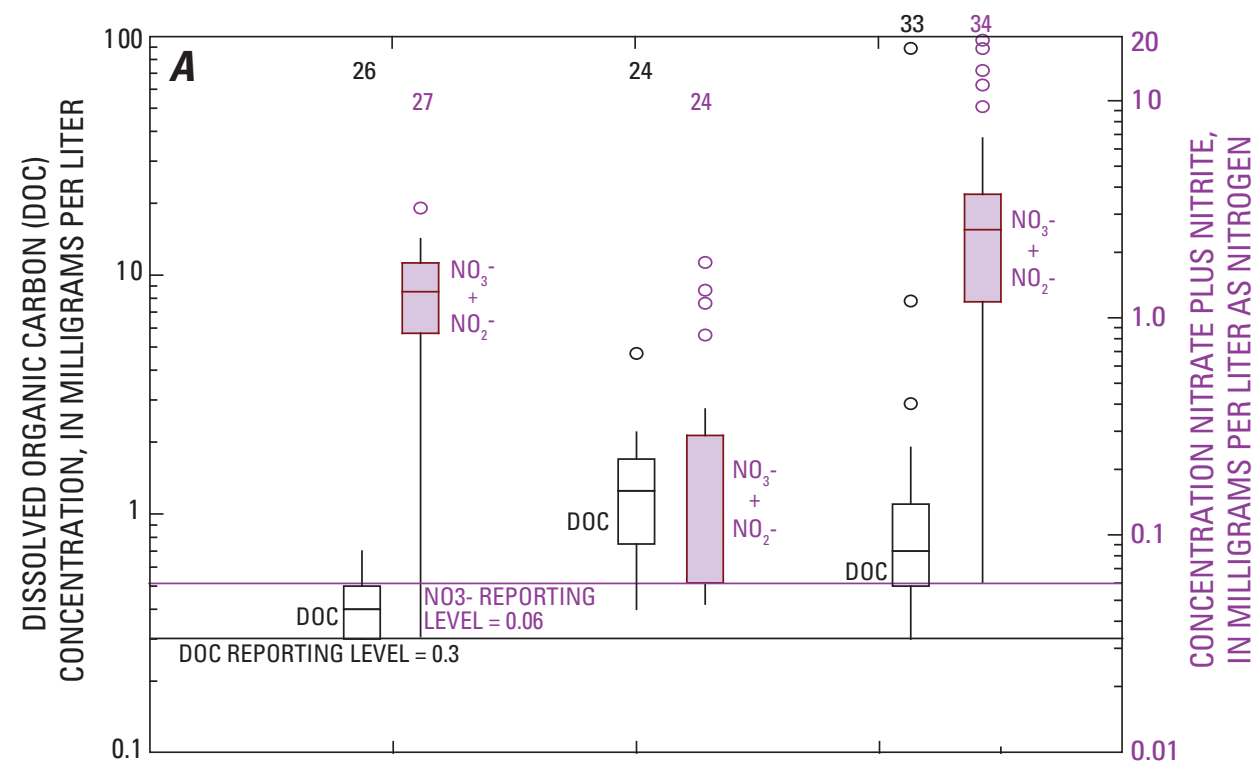

\section{EXPLANATION}

30 Number of values

- Outlier data more than 1.5 times the interquartile range

Data value less than or equal to 1.5 times the interquartile range outside the quartile

75th percentile

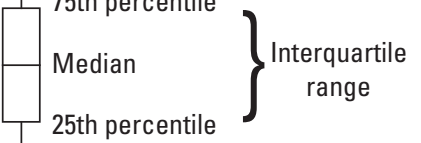

25th percentile

Data value less than or equal to 1.5 times the interquartile range outside the quartile

- Outlier data more than 1.5 times the interquartile range

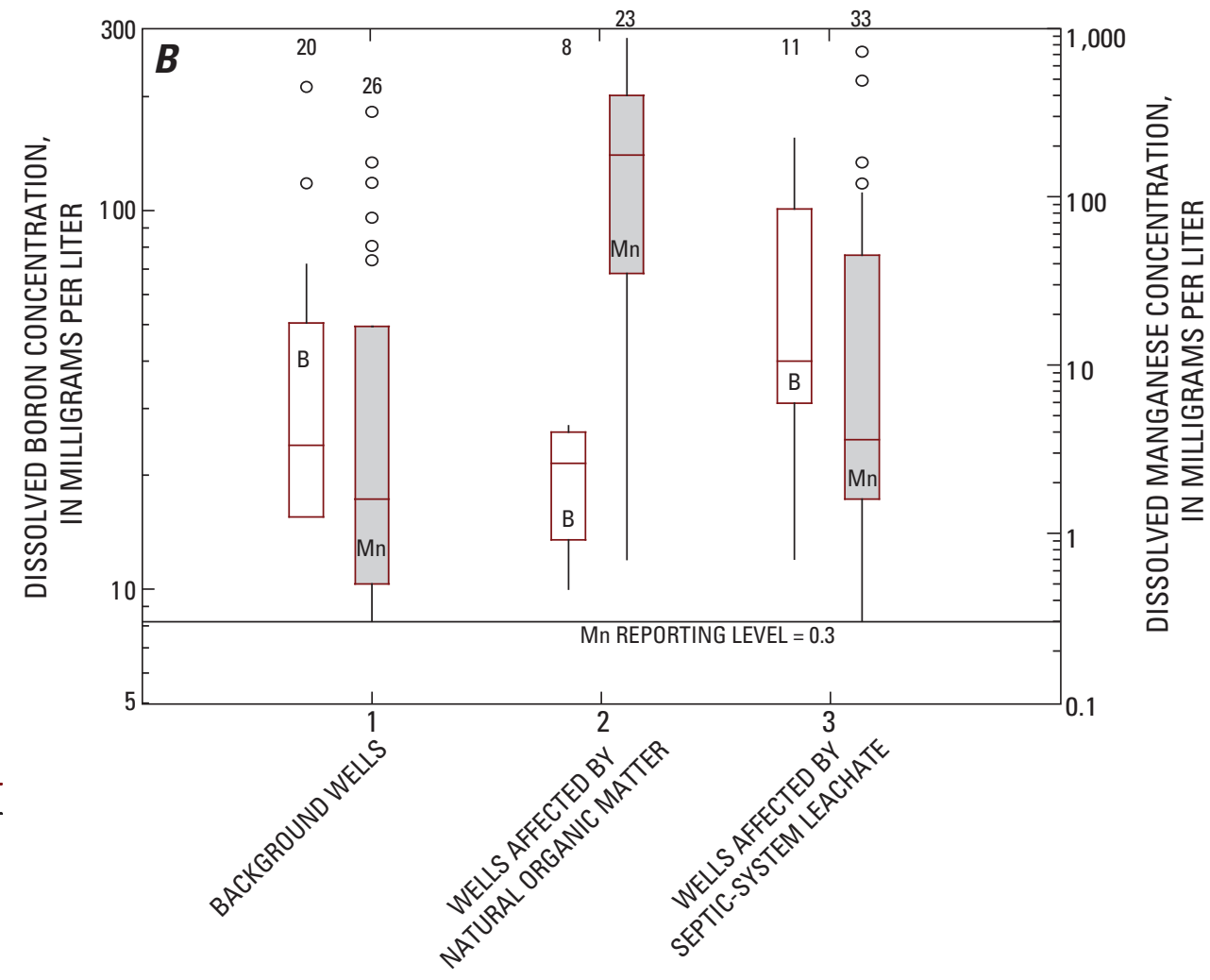

Figure 21. Distributions of concentrations of $(A)$ dissolved organic carbon (DOC) and nitrate plus nitrite $\left(\mathrm{NO}_{3}{ }^{-}+\mathrm{NO}_{2}^{-}\right.$, and $(B)$ dissolved boron $(B)$ and manganese $(\mathrm{Mn})$, in groundwater samples from wells in relation to the group of wells (1) not apparently affected by abundant natural organic matter or septic-system leachate (background), (2) affected primarily by abundant natural organic matter, and (3) affected primarily by septic-system leachate in the Woodbury study area. 
U concentration (fig. 22B). This is consistent with the lower sorption capacity for $\mathrm{U}$ and the net release of $\mathrm{U}(\mathrm{VI})$ by till samples in batch-reactor experiments, as discussed previously in "Adsorption Reactions." Probable sources of U include minerals in the underlying Mesozoic rocks (arkose, shale and siltstone, and mineral-filled veins in basalt) and in upland metamorphic rocks and pegmatites, as well as on ferric hydroxide grain coatings on glacial sediments derived from these source rocks. Geochemical speciation of water samples collected from wells in or near bedrock, which have relatively high $\mathrm{HCO}_{3}$ - concentrations, shows that uranyl-carbonate complexes $\left(\mathrm{UO}_{2}\left(\mathrm{CO}_{3}\right)_{2}^{-2}\right.$ and $\left.\mathrm{UO}_{2}\left(\mathrm{CO}_{3}\right)_{3}^{-4}\right)$ predominate. These uranyl-carbonate complexes can inhibit $\mathrm{U}$ adsorption and contribute to greater $\mathrm{U}$ mobility, as observed in other aquifer systems with high $\mathrm{HCO}_{3}{ }_{3}$ concentrations (Brown and others, 2007). The mobility of the uranyl complex is limited by sorption and higher $\mathrm{pH}$, but with higher concentrations of competing ions, uranyl will tend to desorb from ferric oxyhydroxides, clays, and other mineral surfaces (Davis and others, 2004).

Activities of ${ }^{226} \mathrm{Ra}$ and ${ }^{228} \mathrm{Ra}$ were relatively low (from less than 0.018 to $0.95 \mathrm{pCi} / \mathrm{L}$ and from 0.12 to $0.8 \mathrm{pCi} / \mathrm{L}$, respectively) in the study area (figs. $22 \mathrm{C}$ and $\mathrm{D}$ ) and are consistent with the low concentrations of $\mathrm{U}$ measured in groundwater samples. The activities of ${ }^{226} \mathrm{Ra}$ and ${ }^{228} \mathrm{Ra}$ did not increase with depth, as did $\mathrm{U}$; in fact, the activity of ${ }^{226} \mathrm{Ra}$ was greater in shallow parts of the glacial aquifer and could be related to its greater mobility at lower $\mathrm{pH}$ (Szabo and Zapecza, 1991).

${ }^{222} \mathrm{Rn}$ activities in groundwater samples from the study area ranged from 490 to $13,000 \mathrm{pCi} / \mathrm{L}$, and all samples were greater than the USEPA proposed MCL of $300 \mathrm{pCi} / \mathrm{L}$ (USEPA, 2006a) (fig. 22E). The median ${ }^{222} \mathrm{Rn}$ activity in samples from wells screened in the glacial aquifer of the study area was $1,100 \mathrm{pCi} / \mathrm{L}$, greater than the median of $440 \mathrm{pCi} / \mathrm{L}$ for shallow wells in the glacial aquifer of the CONN (Grady and Mullaney, 1998) and greater than the median of $340 \mathrm{pCi} / \mathrm{L}$ for glacial aquifers in the eastern United States (Ayotte and others, 2007). Three samples, all from bedrock wells, exceeded the alternate MCL (AMCL) of 4,000 pCi/L (USEPA, 2006a). The water samples from two wells in upland Paleozoic rocks had ${ }^{222} \mathrm{Rn}$ activities of 8,600 and $13,000 \mathrm{pCi} / \mathrm{L}$, whereas the samples from wells in fractured basalt had ${ }^{222} \mathrm{Rn}$ activities of 1,600 and 5,500 $\mathrm{pCi} / \mathrm{L} .{ }^{222} \mathrm{Rn}$ activities are high (from 3,000 to $650,000 \mathrm{pCi} / \mathrm{L}$ ) in some of the crystalline rocks in the uplands of Connecticut (Dupuy and others, 1991) and in New England crystalline rocks (median of 2,100 pCi/L) (Ayotte and others, 2007). High activities of ${ }^{222} \mathrm{Rn}$ were associated with the Nonewaug Granite and the Taine Mountain Formation (Thomas and others, 1988). Although ${ }^{222} \mathrm{Rn}$ activity was not correlated with depth in the glacial deposits, the activities in water samples from the bedrock wells generally were higher than those in the glacial deposits (fig. 22E). The short half-life of ${ }^{222} \mathrm{Rn}$ (3.8 days) precludes the possibility that the high activities seen in the glacial aquifer of the study area are derived from the upland bedrock aquifers (Brown and
Zielinski, 2004). The high ${ }^{222} \mathrm{Rn}$ concentrations in groundwater may indicate an abundant but relatively immobile mass of $U$ and ${ }^{226} \mathrm{Ra}$ on aquifer sediment surfaces, as observed in fission track radiographs (fig. 9).

Other naturally occurring contaminants observed in the study area were present in concentrations that were below USEPA primary drinking-water standards, or that exceeded secondary drinking-water standards. High concentrations of dissolved $\mathrm{Mn}$ and (or) Fe reflect anoxic conditions, and one or both exceeded USEPA secondary drinking-water standards of $50 \mu \mathrm{g} / \mathrm{L}$ and $300 \mu \mathrm{g} / \mathrm{L}$, respectively, at wells WY35, WY77, WY80, WY83, WY84, WY85, WY87, WY88, WY95, WY98, WY99, and WY102 (table 8). The communitysupply well, WY66, to the west of the study area (fig. 1), had sufficiently high concentrations of $\mathrm{Mn}$ and $\mathrm{Fe}$ to require $\mathrm{Mn}$ - and Fe-removal treatment by the water utility (table 8 ). High concentrations of $\mathrm{SO}_{4}^{2-}(300 \mathrm{mg} / \mathrm{L})$ and total dissolved solids are associated with groundwater from underlying Mesozoic rocks, as discussed at the beginning of this section, and exceeded the USEPA secondary drinking-water standards of $300 \mathrm{mg} / \mathrm{L}$ and $500 \mathrm{mg} / \mathrm{L}$, respectively, in the water sample from WY106. Trace element concentrations generally were higher in samples from wells in bedrock and near-bedrock glacial deposits, as well as from wells affected by septicsystem leachate and (or) road salt, than in samples from shallow wells in glacial stratified drift that were relatively unaffected by anthropogenic sources (table 8). Dissolved concentrations of $\mathrm{Cu}$ were high in bedrock well WY86, which is near the eastern border fault in the South Brook area that is host to some small $\mathrm{Cu}$ prospect mines, compared to most other wells. Mesozoic basin rocks can have high concentrations of $\mathrm{Cu}$ and $\mathrm{Ba}$; water samples from wells F344 and S401 from the Hartford Basin have high $\mathrm{Cu}$ and $\mathrm{Ba}$ concentrations relative to most other wells, but WY106 had only high concentrations of $\mathrm{Cu}$, and WY83 had only high concentrations of $\mathrm{Ba}$. The elevated concentrations of dissolved $\mathrm{Cu}$ in PSW-1, WY65, and SB120 are typical of supply wells because of the steel screen, casing, and other pipes and fittings that are in contact with the sample water prior to collection. Dissolved concentrations of $\mathrm{Sr}$ and $\mathrm{V}$ were among the highest in samples from wells that generally had constituents reflective of deep groundwater from the Mesozoic basins, including WY106 in the study area and F344 and S401 in the Hartford Basin (fig. 24A). Dissolved concentrations of B were higher in samples from bedrock well WY106 and other wells that reflect Mesozoic basin chemistry (F344 and S401), whereas those of cobalt (Co) were higher in wells screened in sediments likely derived from the Cass Formation (fig. 24B). Although As, U, Cd, and Pb concentrations were high in the 10-percent $\mathrm{HNO}_{3}$ extractions of sediment samples collected adjacent to the well screen at WY83, only As concentrations were high in groundwater samples, indicating that the other constituents were not readily desorbed or weathered from the sediments under the anoxic conditions. Water samples from wells WY35 and WY88 had concentrations of As, Fe, Mn, and DOC that were greater than those concentrations in samples from most other glacial 

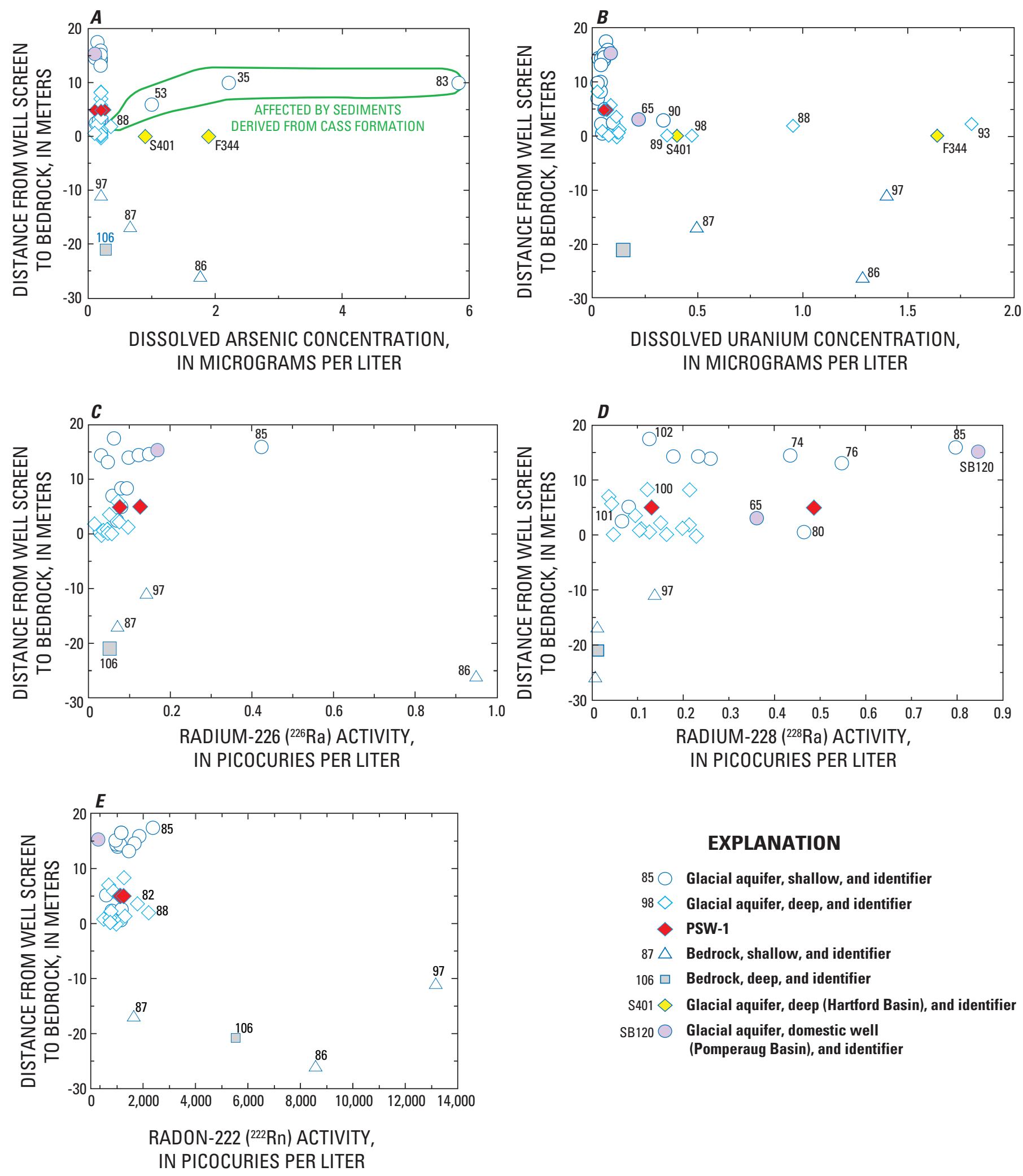

\section{EXPLANATION}

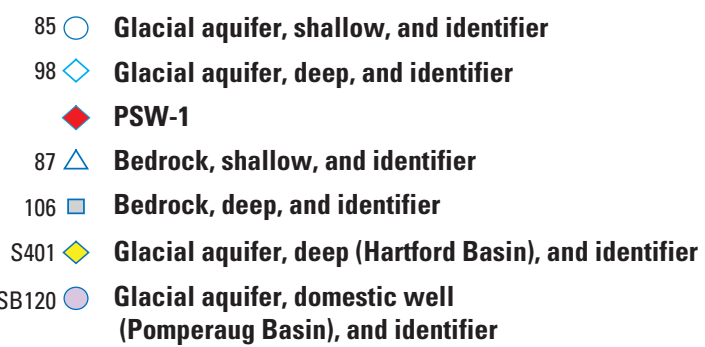

Figure 22. Concentrations of dissolved $(A)$ arsenic, $(B)$ uranium, $(C)$ radium-226, $(D)$ radium-228, and $(E)$ radon-222 in groundwater samples from wells as a function of distance from the well screen to the bedrock interface in the Woodbury study area, and from selected wells elsewhere in the Pomperaug and Hartford Basins, Connecticut. 

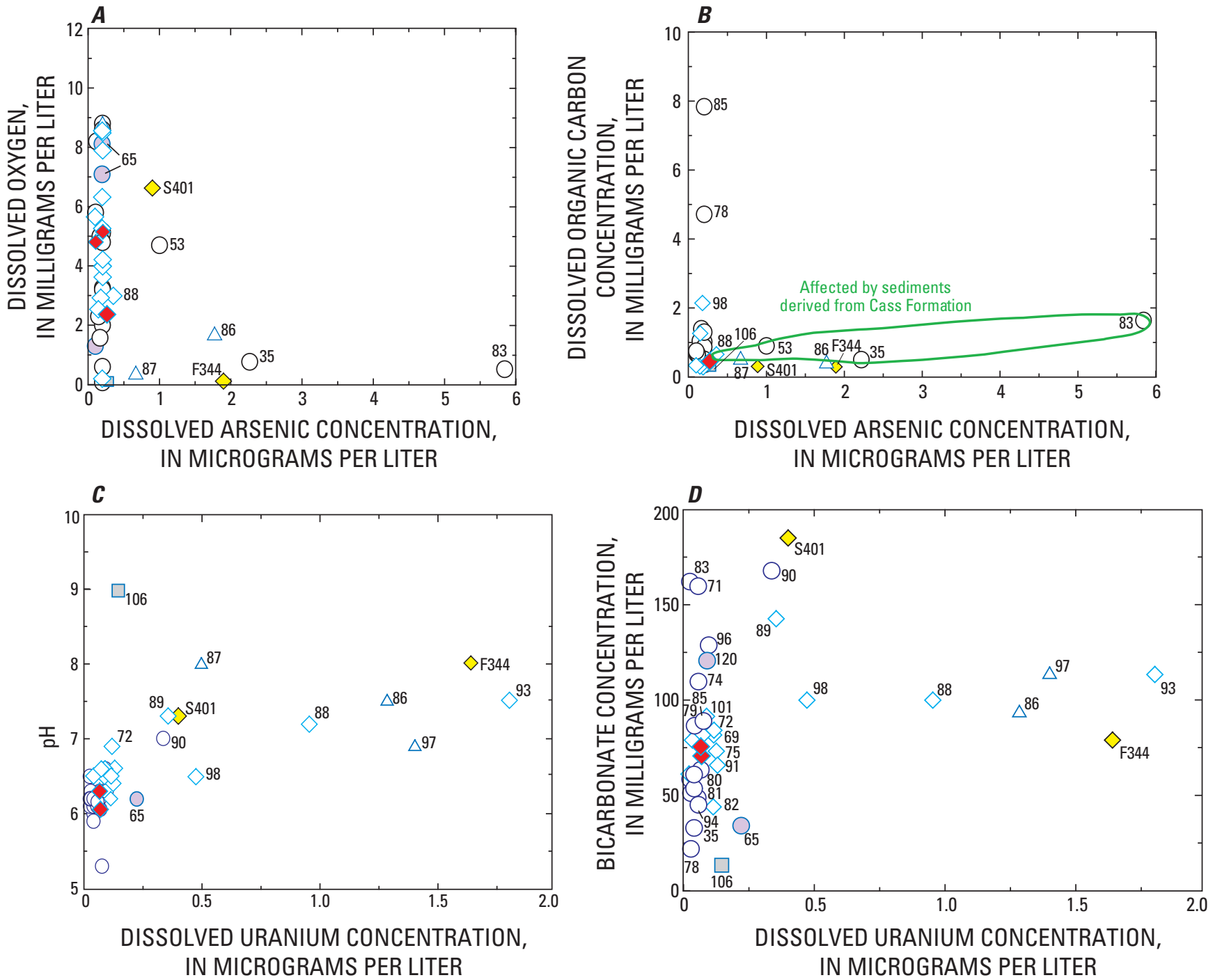

EXPLANATION

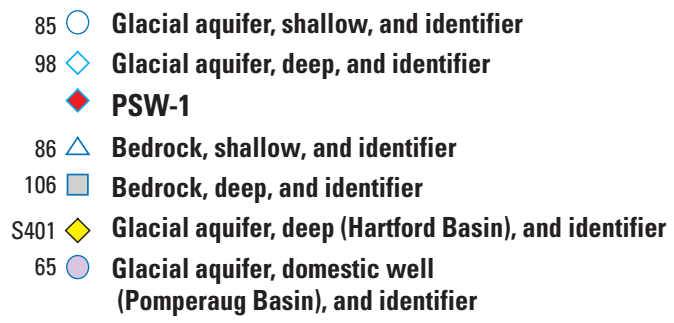

Figure 23. Concentrations of dissolved arsenic as a function of $(A)$ dissolved oxygen (DO), and $(B)$ dissolved organic carbon $(\mathrm{DOC})$, and concentrations of dissolved uranium as a function of $(C) \mathrm{pH}$, and $(D)$ bicarbonate in groundwater samples from wells in the Woodbury study area, and from selected wells elsewhere in the Pomperaug and Hartford Basins, Connecticut. 
wells; as with WY83, the locations of WY35 and WY88 are consistent with the southward direction to which glacial deposits would have been transported (fig. 7). Glacial wells S401 and F344 that overlie rocks of the Newark Supergroup in the Hartford Basin, were found to have high concentrations of constituents such as $\mathrm{As}, \mathrm{Ba}, \mathrm{B}, \mathrm{Cu}, \mathrm{Li}, \mathrm{Sr}, \mathrm{U}$, and $\mathrm{V}$, relative to most other glacial wells in the study area (table 8).

Concentrations of $\mathrm{Ba}, \mathrm{Cd}, \mathrm{Cr}, \mathrm{Cu}, \mathrm{Pb}, \mathrm{Ni}, \mathrm{Sr}, \mathrm{Tl}$, and $\mathrm{Zn}$ were high in groundwater samples from WY85 relative to those from most other wells and appear to be related to septic-system leachate, either in the effluent itself or mobilized from aquifer sediments. Trace elements, including $\mathrm{Cr}, \mathrm{Cu}$, $\mathrm{Pb}, \mathrm{Ni}$, and $\mathrm{Zn}$, can be present in septic cleaners and can be used for source identification (Noss and others, 1987). Wells that are affected by septic leachate, as indicated by the data points labeled "high DOC, septic-system leachate source" (fig. 24B) generally had high concentrations of both B and Co. Although concentrations of B (fig. 24B) were relatively high $(12$ to $155 \mu \mathrm{g} / \mathrm{L}$ ) in some samples from wells that appear to be affected by upgradient septic-tank drainfields, concentrations in samples from WY85 and WY74 were not, probably because the septic-system leachate that affects these sites is primarily from commercial sites that do not use laundry detergents. The groundwater sample from well WY85 had by far the highest $\mathrm{Sr}$ concentration $(0.72 \mathrm{mg} / \mathrm{L})$ of any sample from wells in the study area and may be affected by seawater, which has an average $\mathrm{Sr}$ concentration of $8 \mathrm{mg} / \mathrm{L}$ (Drever, 2005) (fig. 24A); this supports its placement near seawater on the graph of $\mathrm{Cl}-\mathrm{Cl}: \mathrm{Br}$ ratio (fig. 16). Although saltwater intrusion is not a factor at this site, the amount of seawater residue from seafood waste and lobster tanks at a nearby restaurant discharged to the upgradient septic-tank drainfield may have been enough to affect constituents such as $\mathrm{Cl}, \mathrm{Br}$, and $\mathrm{Sr}$ in groundwater samples from WY85. High concentrations of ions in road salt and septic-system leachate can mobilize trace elements through competitive ion exchange, desorption of inner-sphere surface complexes (Hingston and others, 1972), or formation of aqueous complexes (Doner, 1978). Competitive ion exchange takes place whether or not the ions in the incoming solution have a lower affinity for the exchanger than sorbed ions (Appelo and Postma, 1993).

\section{Stable Isotopes}

Stable isotopes were used to determine different chemical sources that affect groundwater quality and the amount of mixing of the waters. The sources may have different isotopic signatures due to the source itself or to chemical fractionation related to evaporative or chemical processes. Stable isotopes measured from constituents in water samples include $\delta^{18} \mathrm{O}$, $\delta \mathrm{D}, \delta^{18} \mathrm{O}$ of $\mathrm{NO}_{3}^{-}, \delta^{15} \mathrm{~N}$ of $\mathrm{NO}_{3}^{-}, \delta^{15} \mathrm{~N}$ of $\mathrm{NH}_{4}^{+}, \delta^{34} \mathrm{~S}$, and $\delta^{13} \mathrm{C}$ of DIC. Stable isotopes also were analyzed in organic and inorganic $\mathrm{C}$ in sediments and rocks, and in sulfide minerals, as mentioned in the methods section.

The stable isotopes $\delta^{18} \mathrm{O}$ and $\delta \mathrm{D}$ were used to help determine surface-water leakage to groundwater and the resulting effect on groundwater chemistry. The global meteoric water line (MWL), which represents a global average of $\delta^{18} \mathrm{O}$ and $\delta \mathrm{D}$ in precipitation (and an average of many local or regional meteoric water lines that differ from the global line as a result of varying climatic and geographic parameters), has a slope of about 8 (Craig, 1961; Clark and Fritz, 1997). Temperature correlates strongly with $\delta^{18} \mathrm{O}$ and $\delta \mathrm{D}$ because the process of rainout distills the heavy isotopes from the vapor (Clark and Fritz, 1997). Precipitation that runs off to streams or that is quickly recharged to groundwater reflects the $\delta^{18} \mathrm{O}$ and $\delta \mathrm{D}$ of the local rainfall. Evaporation of surface water, which is affected by the humidity, causes enrichment of $\delta^{18} \mathrm{O}$ and $\delta \mathrm{D}$ through Rayleigh distillation (Craig, 1961). Transpiration does not involve fractionation (Zimmerman and others, 1967; Förstel, 1982), although some vegetation such as permanent grasses can increase evaporative loss seasonally (Darling and Bath, 1988). Comparison of these ratios in groundwater samples to the MWL can provide information on whether samples primarily follow a distribution reflecting variations in the isotopic composition of precipitation or whether secondary processes such as evaporation have shifted values of $\delta^{18} \mathrm{O}$ and $\delta \mathrm{D}$ off of the MWL (Coplen, 1994). The varying slopes of regional MWLs (not shown) probably reflect the humidity of the local air mass, which imparts a distinctive evaporative isotopic signature to rainfall and hence to stream samples (Kendall and Coplen, 2000).

The $\delta^{18} \mathrm{O}$ and $\delta \mathrm{D}$ data for the study area were compared to a local meteoric water line (LMWLct) that was generated by analysis of stream samples collected from sites in Connecticut; the LMWLct serves as a proxy for the isotopic signature of local precipitation (Kendall and Coplen, 2000) (fig. 25A). Most groundwater samples and surface-water samples from South Brook and the Pomperaug River plotted along a line with a slope of about 9, labeled as LMWLpomp (fig. 25A). The LMWLpomp line is more representative of the study area than the stream data used to produce LMWLct because the $\delta^{18} \mathrm{O}$ and $\delta \mathrm{D}$ values in rainfall vary locally (Coplen and Kendall, 2000). Samples from wells that reflect a greater contribution from older, deep groundwater, including WY106, F344 (deep glacial well in the Hartford Basin), WY82, WY86, and WY77, were depleted in the heavy isotopes $\delta^{18} \mathrm{O}$ and $\delta \mathrm{D}$; these isotopes were depleted during the glacial period (Rozanski and others, 1993). The deep glacial well WY82 is located within $0.1 \mathrm{~km}$ of the eastern border fault, (fig. 7) and chemistry of the water also may have been affected by older basin water, as supported by $\delta^{18} \mathrm{O}$ and $\delta \mathrm{D}$ data values. Aquifer weathering at low temperatures generally has little effect on $\delta \mathrm{D}$, but $\delta^{18} \mathrm{O}$ is enriched by dissolution of calcite (Clayton and others, 1966).

The $\delta \mathrm{D}$ and $\delta^{18} \mathrm{O}$ values in surface waters are enriched by evaporation and were used here to assess the effects of stream leakage on shallow groundwater. Water that has evaporated from surface-water bodies, or that has mixed with evaporated water, plots below the MWL, typically along a divergent line (Drever, 2005) with a slope of about 6 (fig. 25A). Isotope ratios for samples from wells near streams or riparian zones, 


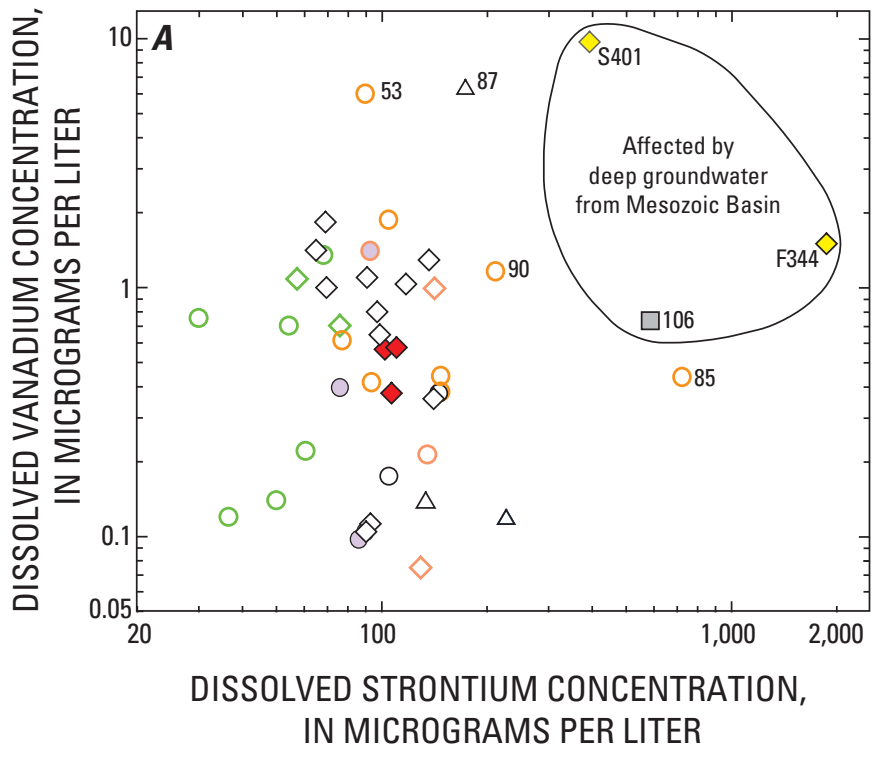

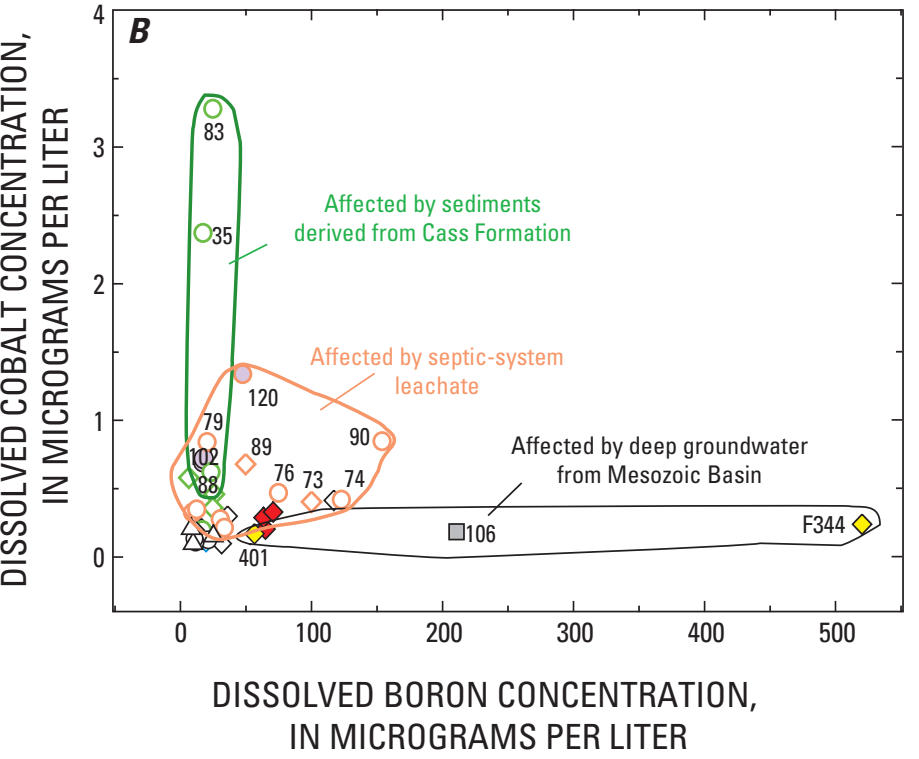

EXPLANATION

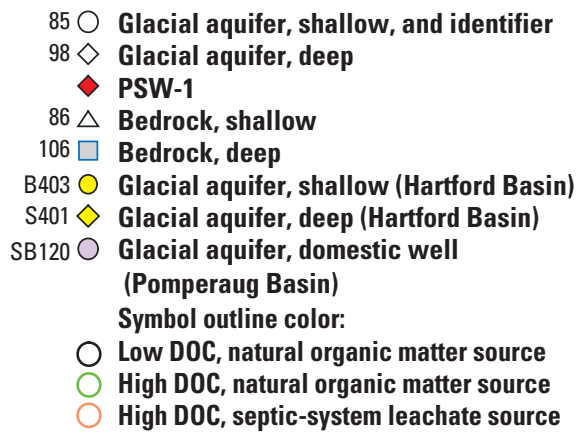

Figure 24. Dissolved concentrations of $(A)$ strontium as a function of vanadium, and $(B)$ boron as a function of cobalt, in groundwater samples from wells in the Woodbury study area, and from selected wells elsewhere in the Pomperaug and Hartford Basins, Connecticut. (DOC, dissolved organic carbon)

in particular South Brook and to a lesser extent the Pomperaug River, plotted along an evaporation line that reflects surfacewater leakage from the Pomperaug River (WY35 and WY88, and one sample at PSW-1), or South Brook (WY78, WY80, WY87, WY98 and WY99) or septic-system leachate (WY71, WY84, and WY85; fig. 25A). The effects of streamflow losses on groundwater chemistry vary; in some cases, solutes in water samples from shallow wells are diluted by stream water. At other wells, such as WY78, the chemistry of groundwater samples was affected by road salt, and solute concentrations increase seasonally. Because surface-water samples and groundwater samples for analysis of $\delta \mathrm{D}$ and $\delta^{18} \mathrm{O}$ values were not always collected at the same time, direct relationships could not be made, and mixing could not be quantified.
Ideally, samples are collected within a period of a few days in summer when $\delta \mathrm{D}$ and $\delta^{18} \mathrm{O}$ values for surface water and groundwater are most different. The plotting of sample data from wells that are affected by septic-system leachate along the evaporation line (fig. 25A) may result from evaporation of water near the points of use, such as dishwashers or showers. Denitrification at some well sites that are affected by septic-system leachate, such as WY85, also could result in $\delta \mathrm{D}$ and $\delta^{18} \mathrm{O}$ values for groundwater samples that plot along the evaporation line; biologically formed $\mathrm{NO}_{3}{ }^{-}$contains $\delta^{18} \mathrm{O}$ depleted water, since one $\mathrm{O}$ atom comes from atmospheric $\mathrm{O}_{2}$, and the other two come from the water (Clark and Fritz, 1997).

The $\delta^{13} \mathrm{C}$ values for DIC in groundwater samples range from -20.7 to -12.2 per mil with a median of -17.8 per mil 
(table 8). The heavier $\delta^{13} \mathrm{C}$ values of calcite in some core samples, including a glacial till sample (-7.34 per mil) at WY90 and a basalt sample (-8.52 per mil) at WY87, are likely affected by heavier $\delta^{13} \mathrm{C}$ values observed in calcite (table 5). The groundwater sample from fractured basalt at WY106 exhibits a heavy $\delta^{13} \mathrm{C}$ value $(-13.6$ per mil) relative to other water samples; based on its near saturation with respect to calcite (table 7), this may indicate dissolution of calcite at some point along its flow path. The $\delta^{13} \mathrm{C}$ values for DIC in some groundwater samples also may be affected by reaction with the lighter $\delta^{13} \mathrm{C}$ values in organic $\mathrm{C}$ from glacial sediments (table 5); wells WY102 and WY100, which are screened below organic-rich sediments, had lighter $\delta^{13} \mathrm{C}$ values of -20.3 and -19.2 per mil, respectively (table 8).

The $\delta^{34} \mathrm{~S}$ of $\mathrm{SO}_{4}{ }^{2-}$ in groundwater samples ranged from 0.39 per mil to 16.4 per mil and appears to reflect several processes and mixtures of sources (table 8; fig. 25B). The source of the light $\delta^{34} \mathrm{~S}_{\text {of }} \mathrm{SO}_{4}{ }^{2-}$ value of 0.39 per mil in the groundwater sample from WY97 (the upland bedrock well) could reflect the oxidation of $\mathrm{FeS}_{2}$, which might be present in secondary fractures. The heaviest $\delta^{34} \mathrm{~S}$ value, 16.4 per mil, in water from WY83 supports the earlier hypothesis that sediments at this well were derived, in part, from the Cass Formation of the Newark Supergroup. The $\delta^{34} \mathrm{~S}$ values in the equivalent rock unit (Passaic Formation) of the Newark Basin range from 3.3 to 11 per mil (El-Tabakh and others, 1997), and the $\delta^{34} \mathrm{~S}$ values in sedimentary $\mathrm{SO}_{4}{ }^{2-}$ in rocks of Jurassic age and older typically range from 10 to 30 per mil, with a mean from 15 to 20 per mil (Holser and Kaplan, 1966). The $\delta^{34} \mathrm{~S}$ values for several deep glacial wells fall along a hyperbolashaped mixing line between that of WY100, which is of intermediate depth about $8.2 \mathrm{~m}$ above bedrock, and WY106, the deep bedrock well that is finished in fractured basalt (fig. 25B). Mixtures of two components that have different isotope ratios and different concentrations of a given element plot as hyperbolas on graphs (Faure, 1986), similar to figure 25B. The curve may result from an exponential relation caused by the fractionation of ${ }^{34} \mathrm{~S}$.

Bedrock well WY106 had high concentrations of $\mathrm{SO}_{4}{ }^{2-}(300 \mathrm{mg} / \mathrm{L})$ and relatively heavy $\delta^{34} \mathrm{~S}(13.6$ per mil) (fig. 25B; tables 7 and 8). The apparent groundwater age (more than 50 years) at WY106 is old relative to ages for other samples in the study area, as discussed in a later section, and the chemistry of the water may reflect contributions from ancient water in fractured Mesozoic basin rocks. On the basis of the high concentrations of $\mathrm{SO}_{4}{ }^{2-}$ and $\mathrm{Ca}$ and low concentrations of $\mathrm{HCO}_{3}^{-}$in this ancient water, together with the mostly arid depositional environment of the Mesozoic rocks in the Pomperaug Basin (LeTourneau and Huber, 2006) and subsequent alteration after rifting, the water composition could result from gypsum or anhydrite dissolution followed by the precipitation of calcite. The $\delta^{34} \mathrm{~S}$ of $\mathrm{SO}_{4}{ }^{2-}$ values for WY83 (16.4 per mil) and WY86 (11.8 per mil) also are heavy but do not plot along the mixing line with WY106 (fig. 25B). The heavy sulfur (S) in water samples from these wells could be caused (1) by $\mathrm{SO}_{4}{ }^{2-}$ reduction and subsequent formation of sulfide minerals such as $\mathrm{FeS}$ and $\mathrm{FeS}_{2}$, which effectively removes the lighter ${ }^{32} \mathrm{~S}$ from the pool, (2) by dissolution of gypsum, or (3) by degradation of organic matter that has heavy $\delta^{34} \mathrm{~S}$. Groundwater samples from wells that had heavy $\delta^{34} \mathrm{~S}$, including WY83, 86, 99, 98, and 78 (fig. 25B), also had high concentrations of DOC and (or) natural organic carbon and, consequently, reducing conditions; $\mathrm{SO}_{4}^{2-}$ concentrations were low, as would be expected under $\mathrm{SO}_{4}{ }^{2-}$ reducing conditions. Similarly, groundwater samples at sites apparently affected by septic-tank drainfields also had low $\mathrm{SO}_{4}{ }^{2-}$ concentrations, but relatively depleted $\delta^{34} \mathrm{~S}$ values in $\mathrm{SO}_{4}{ }^{2-}$ (wells WY70, $71,73,74,85,90$, and 96 ). The difference is likely caused by the reactions subsequent to the reduction of $\mathrm{SO}_{4}{ }^{2-}$ to $\mathrm{H}_{2} \mathrm{~S}$ : in organic-rich sediments, the removal of $\mathrm{S}$ by the formation of sulfide minerals results in enriched ${ }^{34} \mathrm{~S}$ ratios in the residual $\mathrm{SO}_{4}^{2-}$, whereas near septic-tank drainfields, the associated exsolution of $\mathrm{H}_{2} \mathrm{~S}$ results in depleted ${ }^{34} \mathrm{~S}$ ratios in the residual $\mathrm{SO}_{4}^{2-}$.

The $\delta^{15} \mathrm{~N}$ and $\delta^{18} \mathrm{O}$ of $\mathrm{NO}_{3}^{-}$values are used to distinguish among all sources of $\mathrm{NO}_{3}^{-}$, except ammonium fertilizers and bacterially produced soil $\mathrm{NO}_{3}^{-}$(Clark and Fritz, 1997). The $\delta^{15} \mathrm{~N}$ values in $\mathrm{NO}_{3}^{-}$for groundwater samples from most wells were less than 9 per mil, and the $\delta^{18} \mathrm{O}$ values in $\mathrm{NO}_{3}^{-}$generally were less than 5 per mil (fig. 26A). These isotope values, and the sparsity of ammonium fertilizers used in the study area, indicate that the $\mathrm{NO}_{3}^{-}$in most samples formed from decayed organic matter in the soil zone. The relatively high $\delta^{15} \mathrm{~N}$ of $\mathrm{NO}_{3}{ }^{-}$in some of the samples, however, indicates effects from sewage and animal waste and (or) denitrification, which enriches the $\delta^{15} \mathrm{~N}_{\text {in }} \mathrm{NO}_{3}^{-}$. Water samples from six wells had $\delta^{15} \mathrm{~N}$ values greater than 9 per mil, including wells WY71, $73,79,90,92$, and 102 . The small percentage of agricultural land use in the study area is consistent with the depleted $\delta^{18} \mathrm{O}$ of $\mathrm{NO}_{3}{ }^{-}$in samples, relative to those $\delta^{18} \mathrm{O}$ of $\mathrm{NO}_{3}{ }^{-}$in samples from agricultural areas that are affected by nitrate fertilizers (McMahon and others, 2007). It is not likely that atmospheric deposition could produce $\mathrm{NO}_{3}{ }^{-}$concentrations larger than $0.5 \mathrm{mg} / \mathrm{L}$ as $\mathrm{N}$ within the study area, based on average precipitation-weighted concentrations in wet deposition from National Atmospheric Deposition Program (NADP) stations in New England and southern New York (NADP, 2007). $\mathrm{NO}_{3}^{-}$concentrations in shallow groundwater beneath forested areas in Connecticut typically ranged from less than 0.1 to $0.74 \mathrm{mg} / \mathrm{L}$ as N, with a median of $0.19 \mathrm{mg} / \mathrm{L}$ as N (Grady and Mullaney, 1998), so natural soil $\mathrm{N}$ is not a likely source of the high $\mathrm{NO}_{3}^{-}$concentrations in recharge. Groundwater $\mathrm{NO}_{3}^{-}$that originates from septic-tank drainfields is enriched with ${ }^{15} \mathrm{~N}$ as a result of biological fractionation; $\mathrm{NH}_{4}^{+}$is characterized by the enriched $\delta^{15} \mathrm{~N}$ of catabolic organisms (including humans) and microbially converted to $\mathrm{NO}_{3}^{-}$in shallow groundwater (Clark and Fritz, 1997). The presence of other electron donor point sources, including chemical spills or leaking underground storage tanks as in the case of WY95, or natural electron donors such as $\mathrm{FeS}_{2}$ in aquifer sediments, also can cause the conversion of $\mathrm{NO}_{3}{ }^{-}$to $\mathrm{N}_{2}$ (denitrification). The denitrification of $\mathrm{NO}_{3}^{-}$to dissolved $\mathrm{N}_{2}$ and intermediate products results 


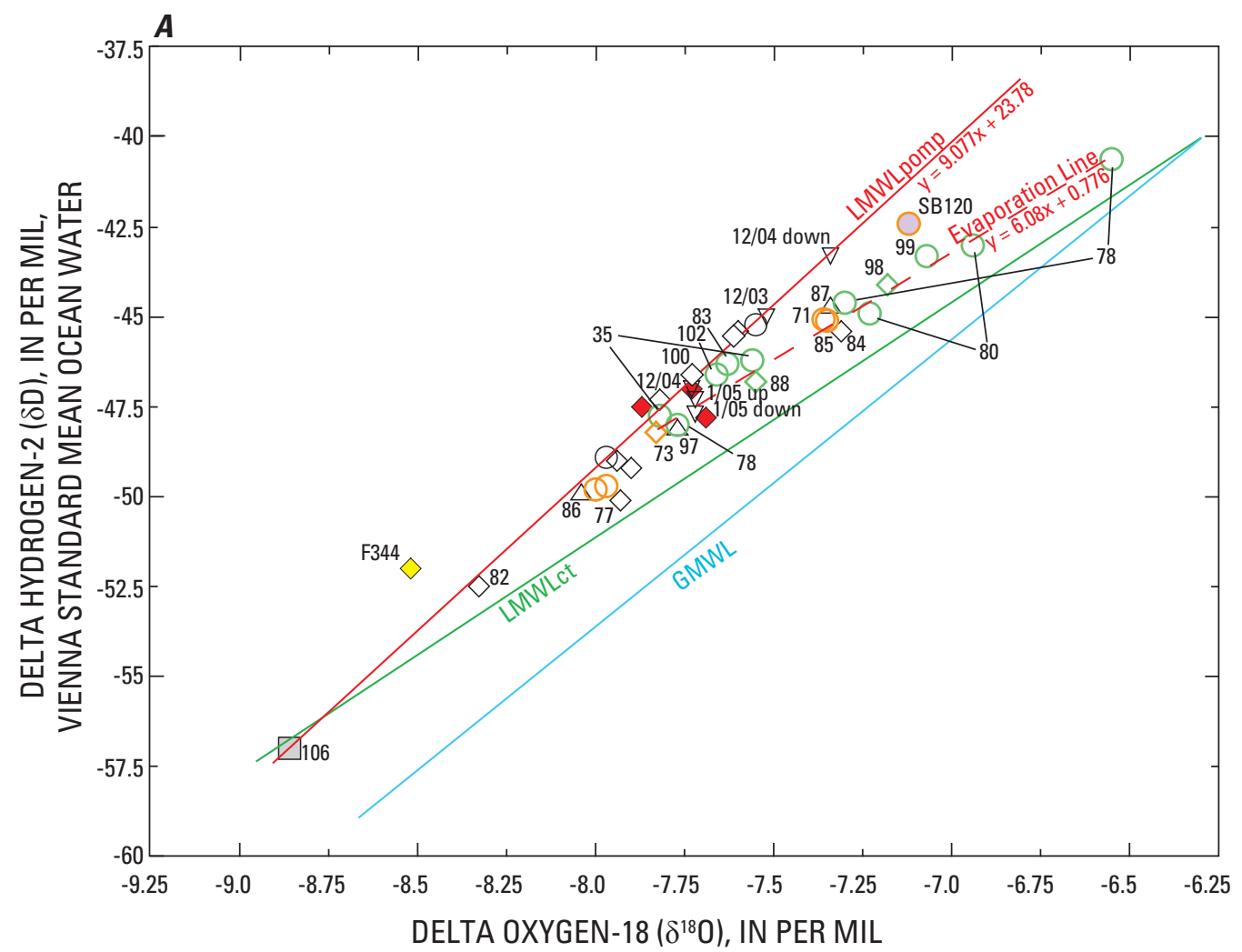

\section{EXPLANATION}

80 Glacial aquifer, shallow, and identifier

$8 \diamond$ Glacial aquifer, deep, and identifier

$\diamond$ PSW-1

$86 \triangle$ Bedrock, shallow, and identifier

$106 \square$ Bedrock, deep, and identifier

F344 $\diamond$ Glacial aquifer, deep, and identifier (Hartford Basin), and identifier SB120 O Glacial aquifer, domestic well (Pomperaug Basin), and identifier

$12 / 03 \nabla$ Pomperaug River

$1 / 05$ up $\nabla$ South Brook Month/year and upstream/ downstream location

- GMWL, global meteoric water line

- LMWLct, local meteoric water line, Connecticut

— LMWLpomp, local meteoric water line, Pomperaug River watershed, inferred

- - Evaporation line, inferred

Symbol outline color

O Low DOC, natural organic matter source

High DOC, natural organic matter source

O High DOC, septic-system leachate source

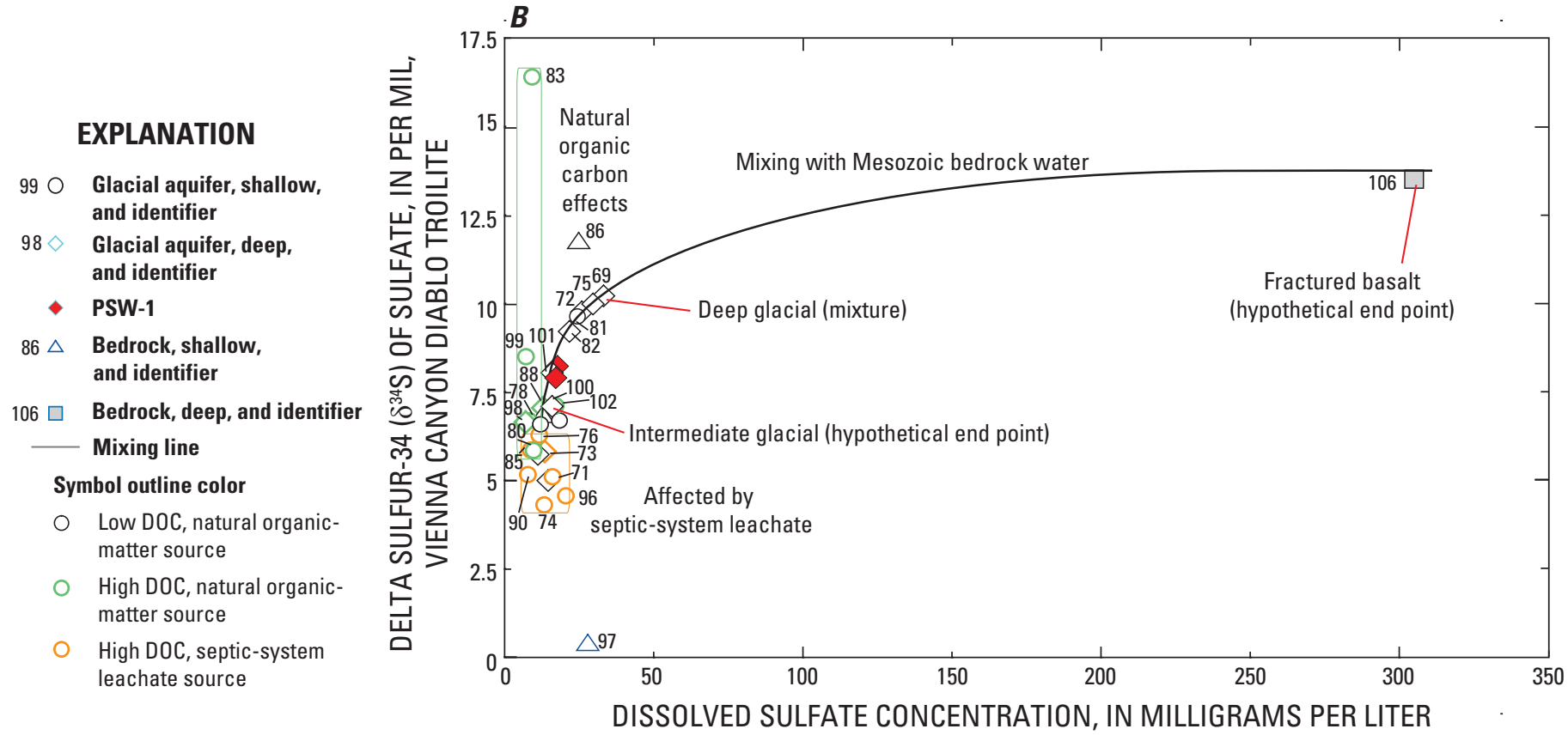

Figure 25. (A) Isotope values of delta oxygen-18 as a function of delta hydrogen-2 for samples of groundwater and surface water, and $(B)$ concentrations of dissolved sulfate as a function of delta sulfur-34 of sulfate for samples of groundwater, collected in the Woodbury study area, and from selected wells elsewhere in the Pomperaug and Hartford Basins, Connecticut. Symbols are color coded for the estimated relative dissolved organic carbon (DOC) source and strength. 
in an increase of $\delta^{15} \mathrm{~N}$ and $\delta^{180}$ of the residual $\mathrm{NO}_{3}^{-}$and is common in reduced groundwaters (Kendall, 1998; Böhlke, 2002). Denitrification of $\mathrm{NO}_{3}^{-}$in locally reduced waters is possible in some samples, based on enriched values of $\delta^{15} \mathrm{~N}$ in $\mathrm{NO}_{3}{ }^{-}$and (or) the presence of excess $\mathrm{N}_{2}$ concentrations up to $7.8 \mathrm{~cm}^{3} / \mathrm{L}$. This could be the case for WY79, 80, 83, 84, 85, 89, 90, and PSW-1 (table 11). The ratio of dissolved gases in the water sample from WY84 appeared to be altered by gas stripping, possibly caused by the generation of $\mathrm{CH}_{4}$ and $\mathrm{HS}^{-}$ from organic-matter decomposition, and so this sample was not included in the analysis. Other samples were not analyzed because of the gas-stripping problem (WY85) or because of poor well yield (WY89 and other wells screened in till). The $\delta^{15} \mathrm{~N}$ and $\delta^{180}$ in $\mathrm{NO}_{3}^{-}$from anoxic water can be positively correlated, and some samples show a slight 1:2 fractionation trend that has been reported for denitrification (fig. 26A), but insufficient data exist for a valid determination for this study (McMahon and others, 2008).

The $\delta^{15} \mathrm{~N}$ of $\mathrm{NO}_{3}^{-}$and concentrations of $\mathrm{NO}_{3}{ }^{-}$in samples with excess $\mathrm{N}_{2}$ were corrected for denitrification, where possible, to determine initial conditions and plotted with concentrations of $\mathrm{NO}_{3}^{-}$as $\mathrm{N}$ (fig. 26B) (McMahon and others, 2008). Where necessary, initial concentrations were obtained by correcting measured concentrations for denitrification effects produced in the aquifer (McMahon and others, 2008). Samples with $\delta^{15} \mathrm{~N}_{\text {of }} \mathrm{NO}_{3}^{-}$less than about 9 per mil likely were derived from soil $\mathrm{NO}_{3}^{-}$and ammonium fertilizer sources, whereas the sample from WY90 with relatively high concentrations of $\mathrm{NO}_{3}^{-}$had more enriched $\delta^{15} \mathrm{~N}$ of $\mathrm{NO}_{3}^{-}$, which likely was derived from septic-tank drainfields (fig. 26B). The groundwater samples with the largest $\mathrm{NO}_{3}^{-}$ concentrations were obtained from wells downgradient from residential septic-tank drainfields; well WY90 had a $\delta^{15} \mathrm{~N}$ value (9.5 per mil) that is consistent with a septic-tank drainfield source. Adequate samples could not be obtained from WY84, WY85, and WY89, which also appear to have been affected by septic-system leachate, because of inadequate yield or gas stripping as described previously. The sample with the second highest $\mathrm{NO}_{3}^{-}$concentration (well WY79) had a $\delta^{15} \mathrm{~N}$ of $\mathrm{NO}_{3}^{-}$of 3.9 per mil, which is consistent with a fertilizer source of N. However, based on its location in the commercial area, and the presence of anthropogenic organic compounds discussed in a later section, "Organic Constituents," well WY79 also appears to be affected by septic-system leachate. $\mathrm{NO}_{3}{ }^{-}$concentrations in samples from WY83 typically were less than the MRL $(0.06 \mathrm{mg} / \mathrm{L}$ as $\mathrm{N})$, but the $\delta^{15} \mathrm{~N}$ of $\mathrm{NH}_{4}^{+}$of one sample was 2.6 per mil (not shown in table 8). Transport of $\mathrm{NO}_{3}^{-}$leached from septic-tank drainfields is limited by denitrification coupled to the oxidation of organic $\mathrm{C}$ (Hinkle and others, 2007). This effect of organic $\mathrm{C}$ from septic-system leachate on groundwater redox chemistry is spatially limited, based on the predominance of oxic conditions throughout most of the aquifer.

\section{Organic Constituents}

Volatile organic compounds and pesticides were detected in groundwater samples from many of the wells and generally were associated with residential, commercial, and industrial land use in the study area.

\section{Volatile Organic Compounds}

Volatile organic compounds were widely detected in water samples from monitoring wells throughout the glacial aquifer, and from PSW-1 (table 12). Thirty VOCs were detected in one or more water samples out of a total of 85 VOCs analyzed (table 13). VOCs were detected at 32 of the 36 wells sampled for this study; one well in a forested area (WY86) was not sampled for VOCs. The concentrations of the 20 most frequently detected VOCs are shown in figure 27. Higher median concentrations and a larger number of detections of VOCs generally were present in samples from the shallow glacial deposits rather than samples from the deep glacial deposits or fractured bedrock (fig. 27) and were associated with commercial, light-industrial, and residential land-use areas (table 13). Point sources are present in the commercial area upgradient from PSW-1, including two or more chlorinated-solvent plumes present since 1978 (Mazzaferro, 1986a; Scott Beals, Sovereign Consulting, Inc., written commun., 2006) and an MTBE plume (fig. 4B) discovered in 2003 that originated from a gasoline station. MTBE was the most frequently detected compound in 47 samples from 19 wells (table 13). Samples with the highest MTBE concentrations (greater than $10 \mu \mathrm{g} / \mathrm{L}$ ) were associated with the MTBE plume, together with other gasoline oxygenates, including TAME and ETBE that were detected in 10 wells and 8 wells, respectively. Chloroform was the second most frequently detected compound, found in 19 wells (47 percent of wells sampled), but concentrations in samples from all but 2 of the well sites were estimated values less than the MRL.

Of the 30 VOCs detected in groundwater samples, concentrations of two compounds-PCE and TCE- exceeded USEPA MCLs, which are legally enforceable drinking-water standards and are the highest allowed concentrations of contaminants in drinking water (USEPA, 2006a) (table 13). Eleven VOC compounds were detected in groundwater from PSW-1: PCE; 1,1,1-TCA; 1,1,2-trichlorotrifluoroethane (CFC-113); TCE; 1,1-dichloroethane (1,1-DCA); cis-1,2dichloroethene (cis-1,2-DCE); 1,1-dichloroethene (1,1-DCE); MTBE; TAME; ETBE; and chloroform. TCE exceeded the MCL in an untreated water sample from PSW-1. A sample from well WY98 had low concentrations of benzene, toluene, ethylbenzene, and xylene (BTEX) compounds (less than $0.2 \mu \mathrm{g} / \mathrm{L}$ ); plus 26 nontarget hydrocarbon compounds (greater than $0.1 \mu \mathrm{g} / \mathrm{L}$ to about $2 \mu \mathrm{g} / \mathrm{L}$ ); and several smaller non-target hydrocarbons (less than $0.1 \mu \mathrm{g} / \mathrm{L}$ ). The nontarget hydrocarbons (compounds that are not on the USEPA Priority Pollutant List) detected include aliphatic 


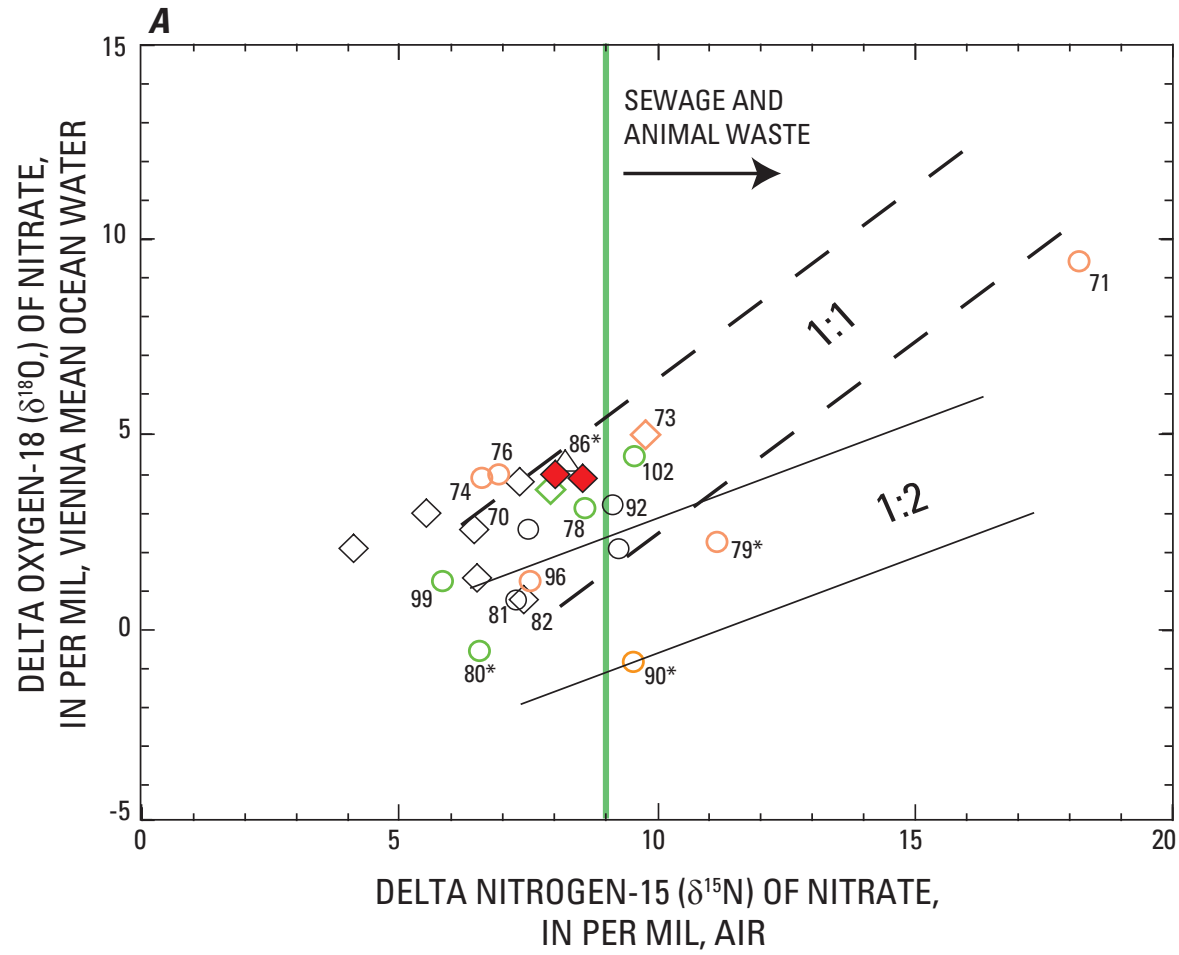

\section{EXPLANATION}

1:1 fractionation trend

- 1:2 fractionation trend

$99 \bigcirc$ Glacial aquifer, shallow, and identifier

$82 \diamond$ Glacial aquifer, deep, and identifier

$\diamond$ PSW-1

$86 \triangle$ Bedrock, shallow, and identifier Symbol outline color

O Low DOC, natural organic-matter source

O High DOC, natural organic-matter source

O High DOC, septic-system leachate source

*Well sample contained excess nitrogen gas

\section{EXPLANATION}

\section{_ Mixing line}

$99 \bigcirc$ Glacial aquifer, shallow, and identifier

$82 \diamond \quad$ Glacial aquifer, deep, and identifier

PSW-1

$86 \triangle$ Bedrock, shallow, and identifier

Symbol outline color

O Low DOC, natural organic-matter source

O High DOC, natural organic-matter source

- High DOC, septic-system leachate source *Well sample contained excess nitrogen gas, and values have been corrected for denitrification

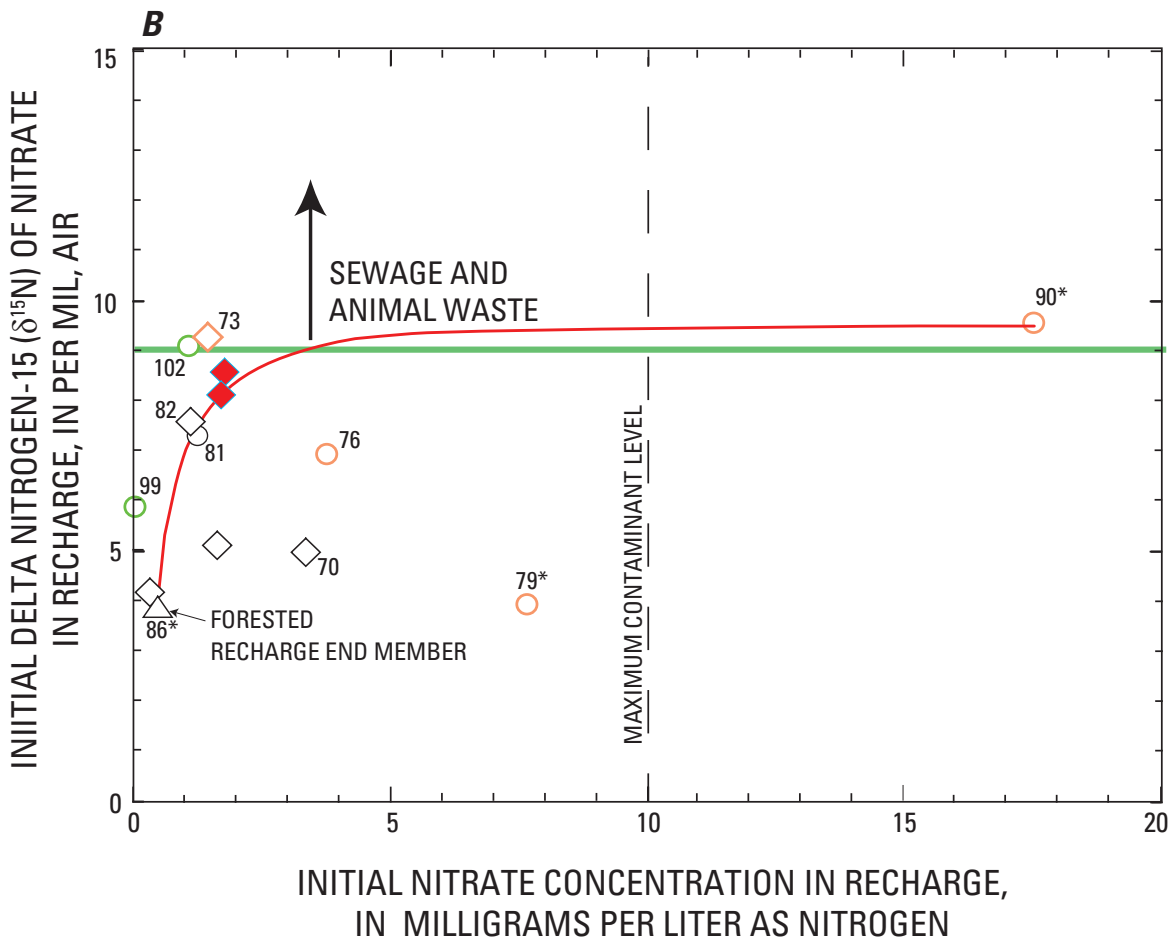

Figure 26. (A) Delta nitrogen-15 as a function of delta oxygen-18 values, and $(B)$ initial nitrate in recharge as a function of initial delta nitrogen-15 values in recharge, corrected for denitrification. The lines indicate the range of fractionation trends reported for nitrate reduction. Mixing lines show some possible source contributions to nitrate in PSW-1 samples. (Modified from McMahon and others, 2008.) 
Table 11. Summary of recharge temperatures determined from dissolved gas concentrations in groundwater samples from wells in the study area, Woodbury, Connecticut, 2003-05.

[NA, not applicable; ID, identifier; ${ }^{\circ} \mathrm{C}$, degrees Celsius; bedrock wells shaded gray; $\mathrm{cm}^{3} \mathrm{STP} / \mathrm{L}$, cubic centimeters per liter at standard temperature and pressure, which is 25 degrees celsius and 1 atmosphere; <, less than; mg/L, milligrams per liter; $\mathrm{O}_{2}$, dissolved oxygen; $\mathrm{Ar}$, argon; $\mathrm{Ne}$, neon; $\mathrm{N}_{2}$, nitrogen gas; integrity of recharge temperature: 0 , no/unacceptable gas measurements, estimated based on average; 1 , Ar-Ne gas used to calculate (greatest integrity); 2, Ar- $\mathrm{N}_{2}, \mathrm{O}_{2}$ less than $3 \mathrm{mg} / \mathrm{L} ; 3, \mathrm{Ar}-\mathrm{N}_{2}, \mathrm{O}_{2}$ greater than $3 \mathrm{mg} / \mathrm{L}$ (least integrity)]

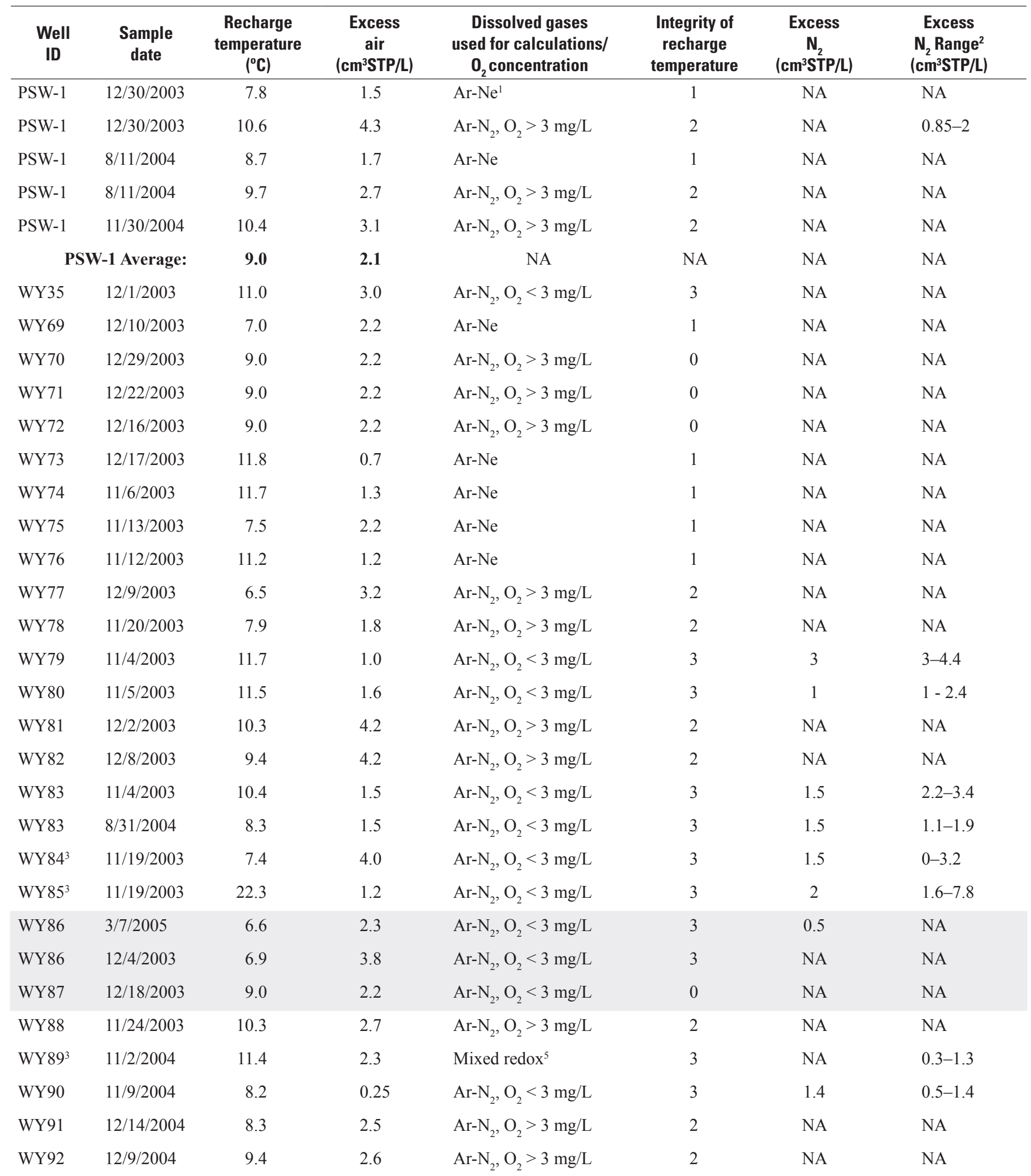


Table 11. Summary of recharge temperatures determined from dissolved gas concentrations in groundwater samples from wells in the study area, Woodbury, Connecticut, 2003-05.-Continued

[NA, not applicable; ID, identifier; ${ }^{\circ} \mathrm{C}$, degrees Celsius; bedrock wells shaded gray; $\mathrm{cm}^{3} \mathrm{STP} / \mathrm{L}$, cubic centimeters per liter at standard temperature and pressure, which is 25 degrees celsius and 1 atmosphere; <, less than; mg/L, milligrams per liter; $\mathrm{O}_{2}$, dissolved oxygen; Ar, argon; Ne, neon; $\mathrm{N}_{2}$, nitrogen gas; integrity of recharge temperature: 0 , no/unacceptable gas measurements, estimated based on average; 1 , Ar-Ne gas used to calculate (greatest integrity); 2, Ar- $\mathrm{N}_{2}, \mathrm{O}_{2}$ less than $3 \mathrm{mg} / \mathrm{L} ; 3, \mathrm{Ar}-\mathrm{N}_{2}, \mathrm{O}_{2}$ greater than $3 \mathrm{mg} / \mathrm{L}$ (least integrity)]

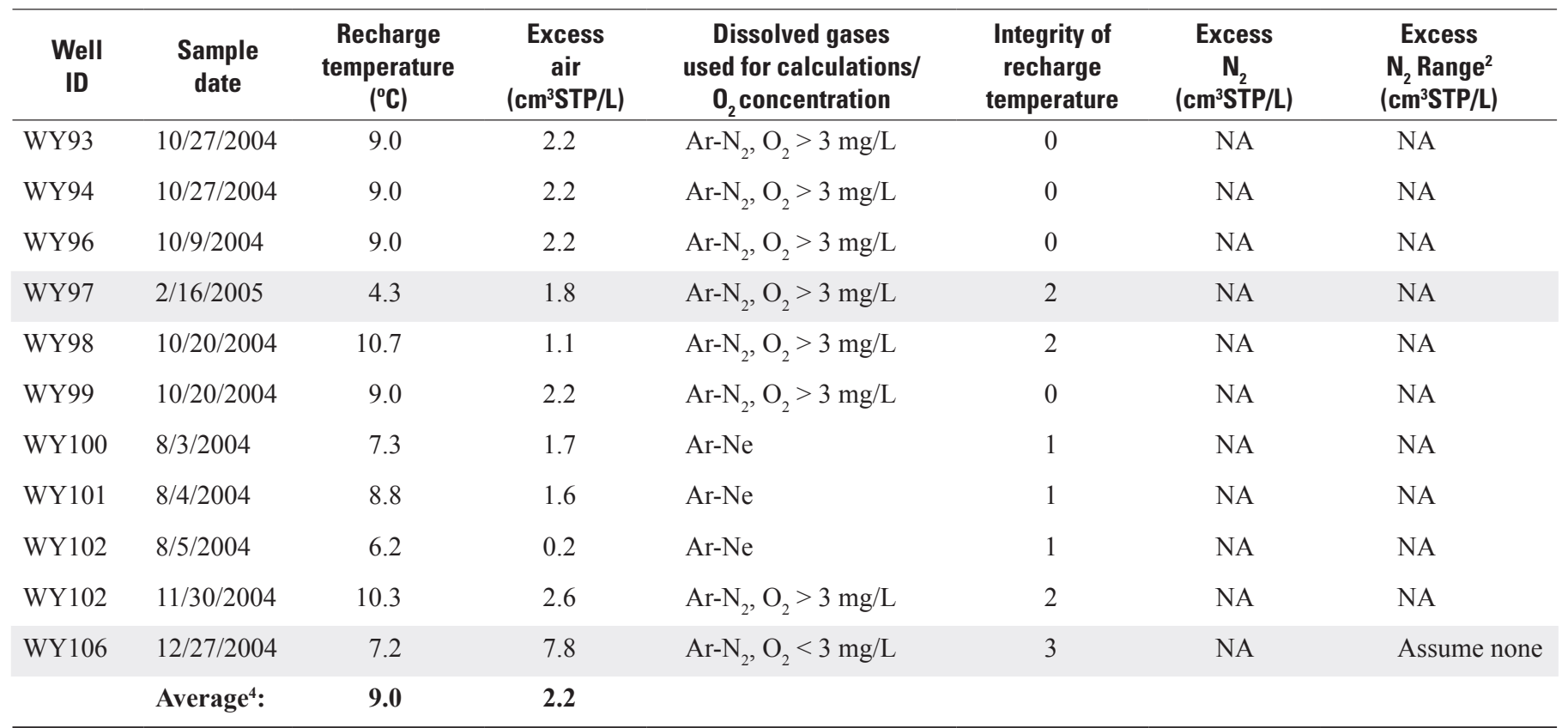

${ }^{1}$ Assumes complete dissolution of excess air.

${ }^{2}$ Based on uncertainty analysis, using average recharge temperature and excess air values.

${ }^{3}$ Assumes complete dissolution of excess air.

${ }^{3}$ Questionable measurement due to possible gas stripping.

${ }^{4}$ Average is based on integrity of measurement ( 1 or 2 ).

${ }^{5}$ The presence of dissolved oxygen is inconsistent with the presence of other redox indicators, as explained in Appendix 4.

hydrocarbons - alkanes, alkenes, and a few cycloalkanes. A chromatogram of these compounds has a profile of peaks similar to kerosene; a nearby home or septic-tank drainfield may be the source.

Several gasoline-related compounds were detected in samples from monitoring wells, including gasoline oxygenates and gasoline hydrocarbons. The MTBE plume was discovered in 2003 after an MTBE concentration of $300 \mu \mathrm{g} / \mathrm{L}$ was measured in a sample from WY76, for this study, and $270 \mu \mathrm{g} / \mathrm{L}$ was measured in a backup community-supply well (Kevin Moran, United Water Connecticut, Inc., written commun., 2003). Concentrations of MTBE in a sample from PSW-1 increased by more than an order of magnitude from 2002 to 2003 , to $7.5 \mu \mathrm{g} / \mathrm{L}$. During this time, reformulated gasoline in the Connecticut area typically accounted for about 6 percent MTBE by weight $(600,000 \mathrm{mg} / \mathrm{kg})$, but Connecticut banned its sale and use as a gasoline additive on or after January 1, 2004 (Connecticut Department of
Environmental Protection, 2004). Concentrations of MTBE in monitoring wells at the gasoline station source were $590,000 \mu \mathrm{g} / \mathrm{L}$, and concentrations of benzene, toluene, ethylbenzene, and xylene were 9,200 $\mu \mathrm{g} / \mathrm{L}, 36,000 \mu \mathrm{g} / \mathrm{L}$, $3,500 \mu \mathrm{g} / \mathrm{L}, 16,000 \mu \mathrm{g} / \mathrm{L}$, respectively. Also, the concentration of isopropyl benzene was $168 \mu \mathrm{g} / \mathrm{L}$, that of TAME was $69,000 \mu \mathrm{g} / \mathrm{L}$, ETBE was $2,000 \mu \mathrm{g} / \mathrm{L}$, and tert-butyl alcohol [tert-butanol; 2-methyl-2-propanol] was 9,100 $\mu \mathrm{g} / \mathrm{L}$ (Scott Beals, Sovereign Consulting, Inc., written commun., 2006). The duration of the gasoline spill is not known. In a sample collected on August 2, 2004, at well WY95, which is only about $180 \mathrm{~m}$ downgradient from the gasoline station source, the concentration of MTBE was 17,000 $\mu \mathrm{g} / \mathrm{L}$; benzene, $0.94 \mu \mathrm{g} / \mathrm{L}$; ethylbenzene, $0.12 \mu \mathrm{g} / \mathrm{L}$; and toluene, below detection. The other gasoline oxygenates TAME, ETBE, and diisopropyl ether were present in WY95 samples at concentrations as great as $2,800 \mu \mathrm{g} / \mathrm{L}, 41 \mu \mathrm{g} / \mathrm{L}$, and $0.41 \mu \mathrm{g} / \mathrm{L}$, respectively (table 12). Concentrations of MTBE in samples 
from PSW-1 peaked at $29 \mu \mathrm{g} / \mathrm{L}$ on two occasions in 2005 , then decreased to $2.1 \mu \mathrm{g} / \mathrm{L}$ or lower in the monthly sampling from December 2005 through June 2006 (Scott Beals, Sovereign Consulting, Inc., written commun., 2006).

The BTEX compounds also were detected in water samples from the study area but at lower concentrations and much less frequently than other compounds in gasoline, such as MTBE. Benzene was detected at $9,200 \mu \mathrm{g} / \mathrm{L}$ at the source of the gasoline spill and decreased by about four orders of magnitude over the $180 \mathrm{~m}$ to WY95, the well with the highest concentration of gasoline oxygenates. MTBE generally did not occur with other gasoline compounds except when detected at high concentrations in this study. Likewise, MTBE was not detected with other gasoline-related compounds in a national study of VOCs, probably because of the higher solubility, lower capacity for sorption, and greater persistence of MTBE in groundwater relative to other gasoline hydrocarbons (Zogorski and others, 2006). Low concentrations of benzene and (or) toluene were detected at other wells that could be associated with spills of gasoline or fuel oil, including WY85, 88, 89, 90, 93, 94, 96, 98, and 99. The compound 1,2,4-trimethylbenzene, which mainly is used as a gasoline additive, was detected in some of these same wells (WY90, 94, 95, and 99). However, this compound also is used in solvents, dyes, and perfumes (Zogorski and others, 2006) and could be related to septic-system leachate.

Chloroform was detected in 10 of the shallow glacial wells and in 7 of the deep glacial wells, or 45 percent of the wells sampled. The high detection rate of chloroform in this study is consistent with other groundwater VOC studies in the CONN (Grady and Mullaney, 1998) and in the Nation's drinking-water-supply wells (Zogorski and others, 2006). Potential sources of chloroform in groundwater include recharge of chlorinated water, direct releases such as spills and leaking underground storage tanks, dehalogenation of tetrachloromethane, bleach in septic-tank drainfields, and some natural sources (Ivahnenko and Barbash, 2004). Chloroform also is a disinfection byproduct that is produced during the chlorination of drinking water and wastewater that contains naturally occurring organic material. The trihalomethanes include chloroform (trichloromethane), bromodichloromethane, dibromochloromethane, and bromoform (tribromomethane), but only chloroform was detected in the study area. Chloroform generally was detected in residential and commercial areas and not in undeveloped areas, so its occurrence in the wells sampled is probably not natural. The wells in which chloroform was detected generally coincide with areas of water-supply distribution pipes, which carry chlorinated water, and septic-tank drainfields at commercial and residential properties with publicwater supply. In a national study of VOCs, chloroform in groundwater was statistically associated with the percentage of urban land, the number of Resource Conservation and Recovery Act (RCRA) hazardous-waste facilities, the number of gasoline storage sites, and septic drainfield density (Zogorski and others, 2006). Chloroform was detected at concentrations as great as $480 \mu \mathrm{g} / \mathrm{L}$ in groundwater samples from the source area of the gasoline spill and as great as $350 \mu \mathrm{g} / \mathrm{L}$ near a grocery-store septic-tank drainfield; the source of chloroform at these wells may have been cleaning products (bleach) used for disinfection of a noncommunity supply well (Scott Beals, Sovereign Consulting, Inc., written commun., 2006). Detections of chloroform associated with benzene, toluene, PCE, TCE, 1,1-DCA, and CFC-13 in water samples from WY88 and WY35, which are completed in the glacial aquifer in a gravel-mined area to the west of PSW-1 and the Pomperaug River, indicate recharge of utility-supplied drinking water with wastewater under an area that, historically, may have been used for rinsing heavy equipment.Chlorinated solvents were the third most frequently detected class of organic (anthropogenic) compounds in this study area. In samples of groundwater nationwide, PCE, TCA, and TCE were among the top 10 most often detected compounds of 55 VOCs analyzed (Moran and others, 2007). Chlorinated solvents are used for vapor degreasing, cold cleaning, dry cleaning, in electronics manufacturing, and as septic-tank cleaners (Murphy and Morrison, 2004). Some of the detected solvents likely originated as spills in the commercial area and include PCE, TCA, CFC-113, TCE, and cis-1,2-DCE (Sovereign Consulting, Inc., 2004a). Most chlorinated solvents belong to a group of compounds that can form dense, nonaqueous-phase liquids (DNAPLs), which leave a free-phase residual that can persist in aquifers for many years. Concentrations of PCE and TCE, for example, have changed little in the water pumped from PSW-1 during the past 25 years. In this study, PCE was detected in 42 percent of wells, and concentrations were highest in samples from several monitoring wells downgradient from the commercial area (table 13); concentrations of PCE in samples from well WY95 exceeded the USEPA MCL of $5 \mu \mathrm{g} / \mathrm{L}$ at concentrations up to $11 \mu \mathrm{g} / \mathrm{L}$. TCE was detected in 33 percent of wells, at concentrations up to $25 \mu \mathrm{g} / \mathrm{L}$; 4 wells (WY76, WY100, WY102, and PSW-1) exceeded the USEPA MCL of $5 \mu \mathrm{g} / \mathrm{L}$ at concentrations up to $25 \mu \mathrm{g} / \mathrm{L}$. Concentrations of TCE exceeded the MCL in 4 of the 6 groundwater samples collected from PSW-1 before treatment, and ranged 4.3 to $16 \mu \mathrm{g} / \mathrm{L}$ (table 12). The compound 1,4-dichlorobenzene (paradichlorobenzene, or p-DCB) has some use as a solvent but is primarily used as a fumigant pesticide and will be discussed in the section on pesticides.

Although the strengths of chlorinated solvents at the source are not known, samples collected during an aquifer pumping test in March 2005 from a non-USGS well located $9 \mathrm{~m}$ northwest of WY95 for treatment of the MTBE contamination (Scott Beals, Sovereign Consulting, Inc., written commun., 2005) contained high concentrations of chlorinated solvents when the pumping rate was doubled. Concentrations in groundwater samples were $13.4 \mu \mathrm{g} / \mathrm{L}$ for PCE and $8.1 \mu \mathrm{g} / \mathrm{L}$ for TCE at a dry cleaner, $470 \mu \mathrm{g} / \mathrm{L}$ for TCA at the recovery well, and $410 \mu \mathrm{g} / \mathrm{L}$ for TCE and $180 \mu \mathrm{g} / \mathrm{L}$ for TCA at well NW19D. Groundwater at the source area was pumped into an air-stripping treatment system from June 21, 


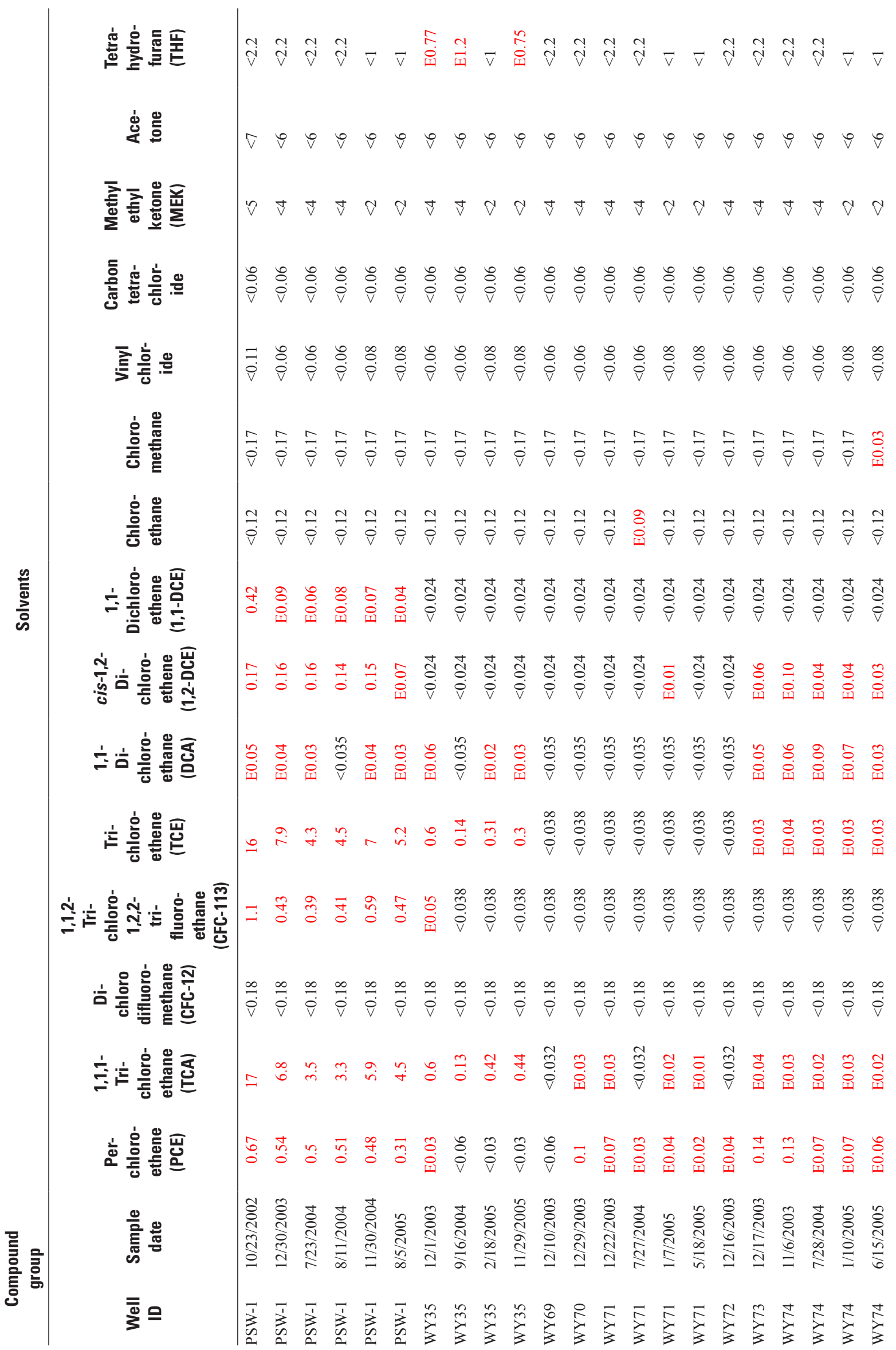




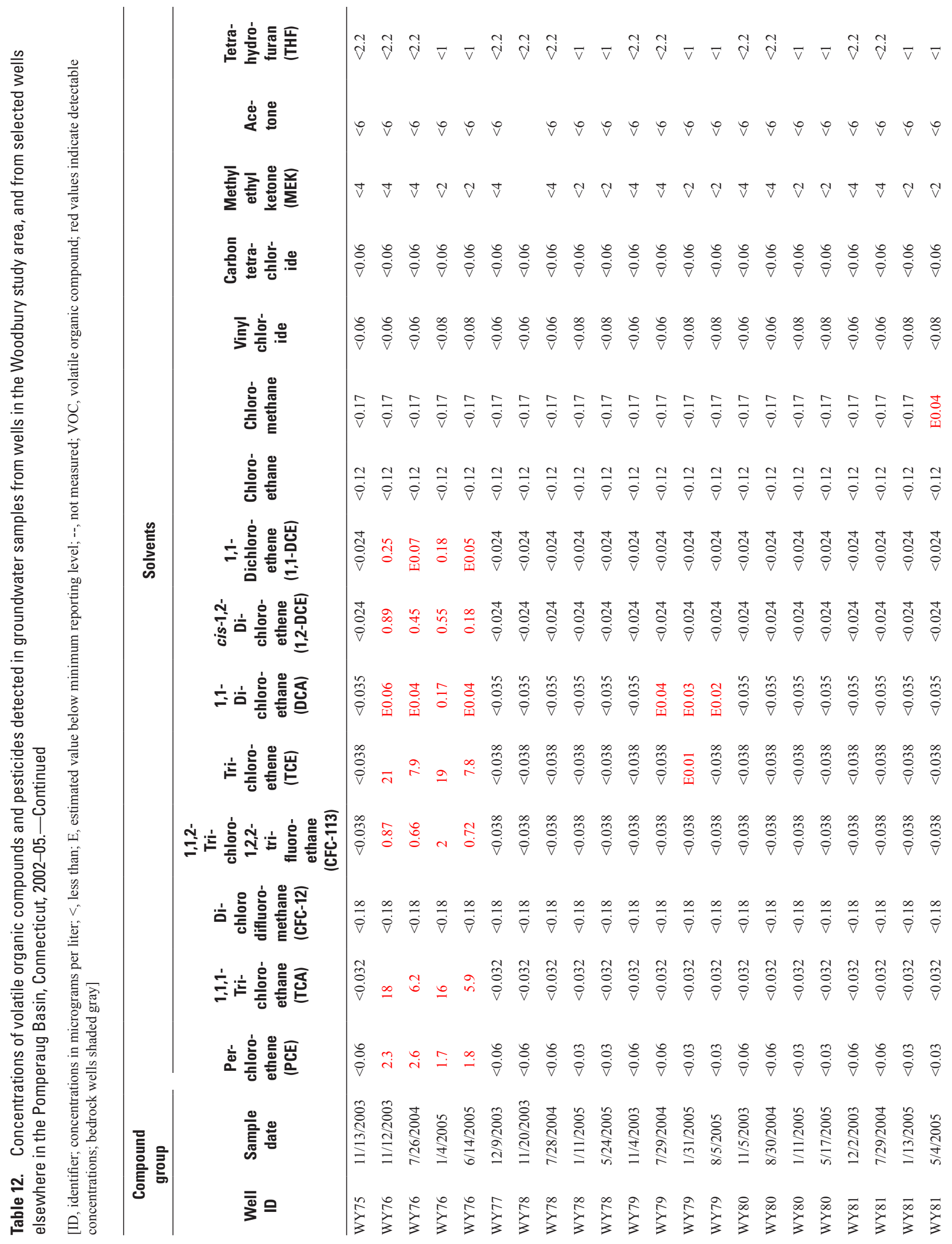




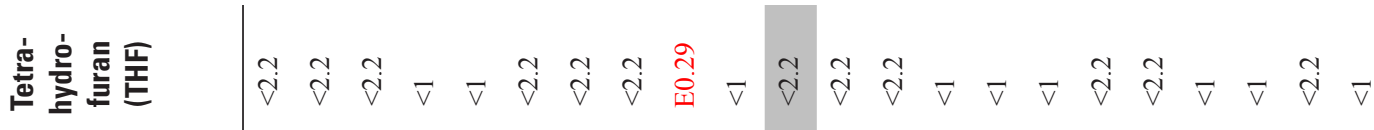

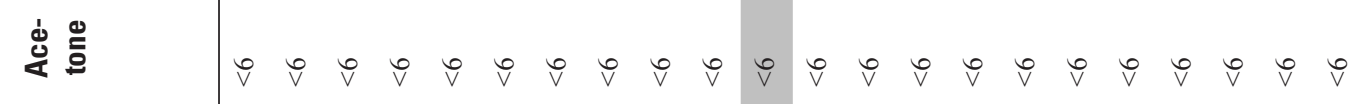

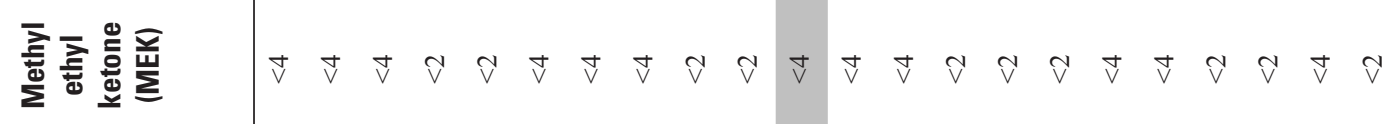

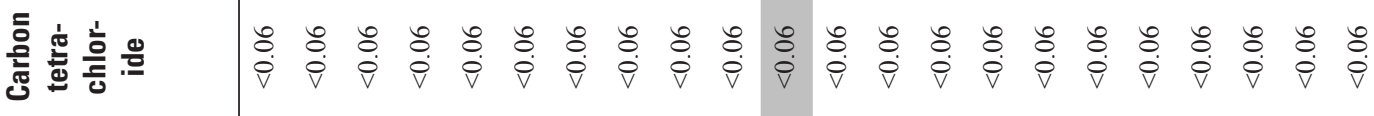

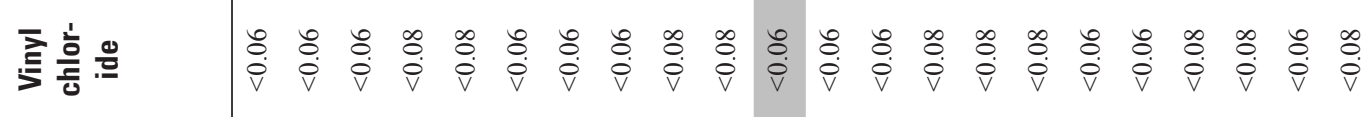

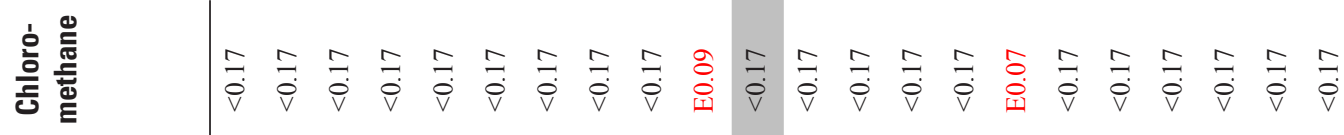

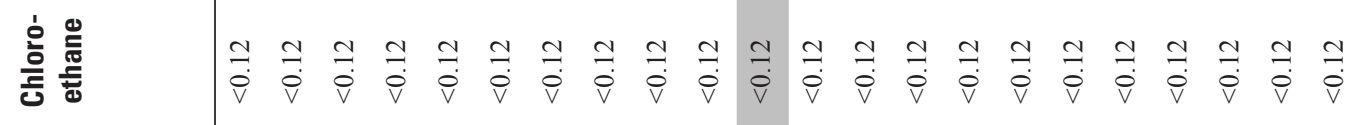

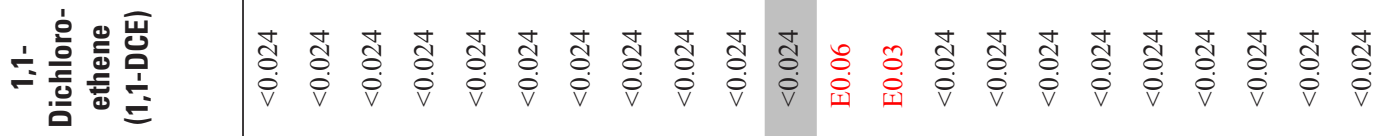

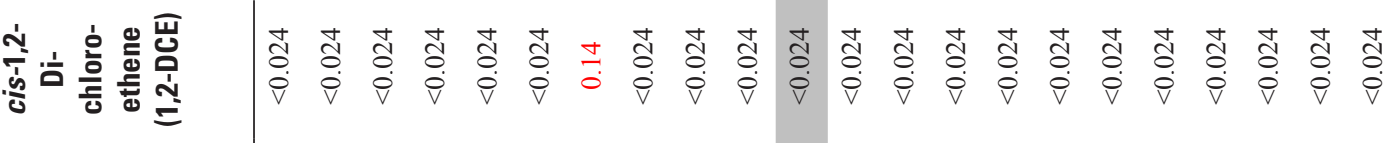

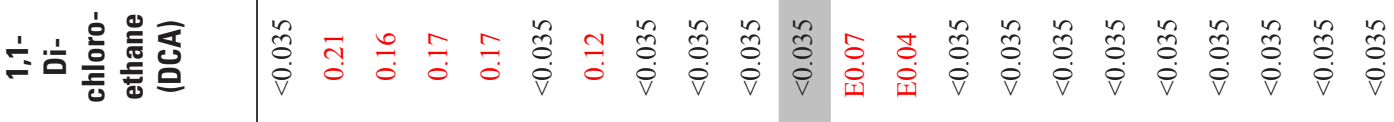

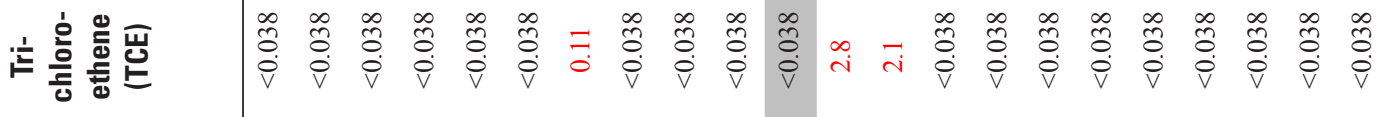

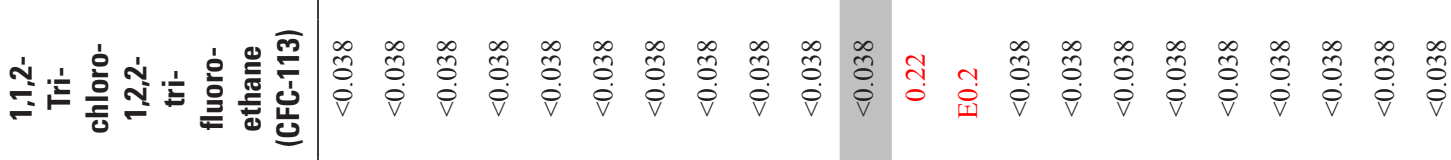

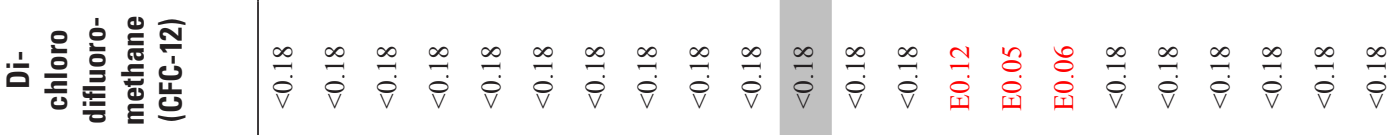

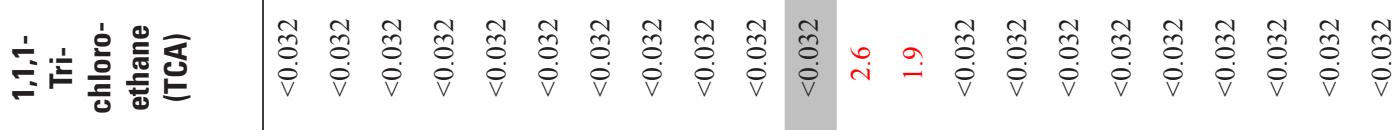

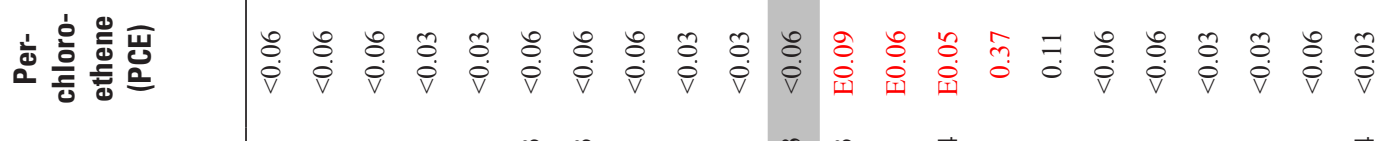

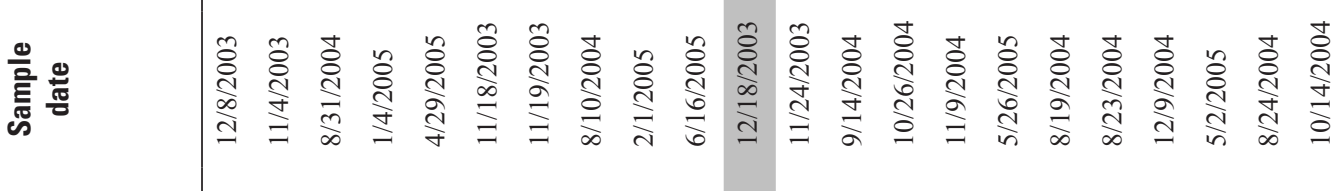

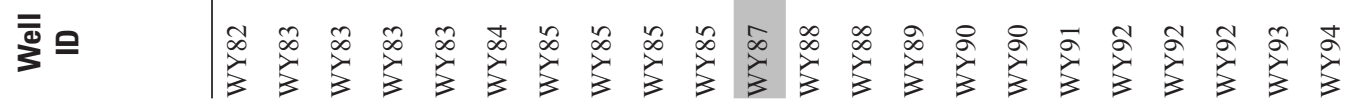




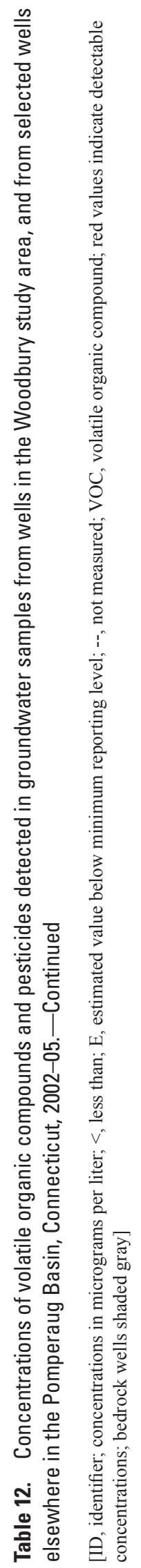

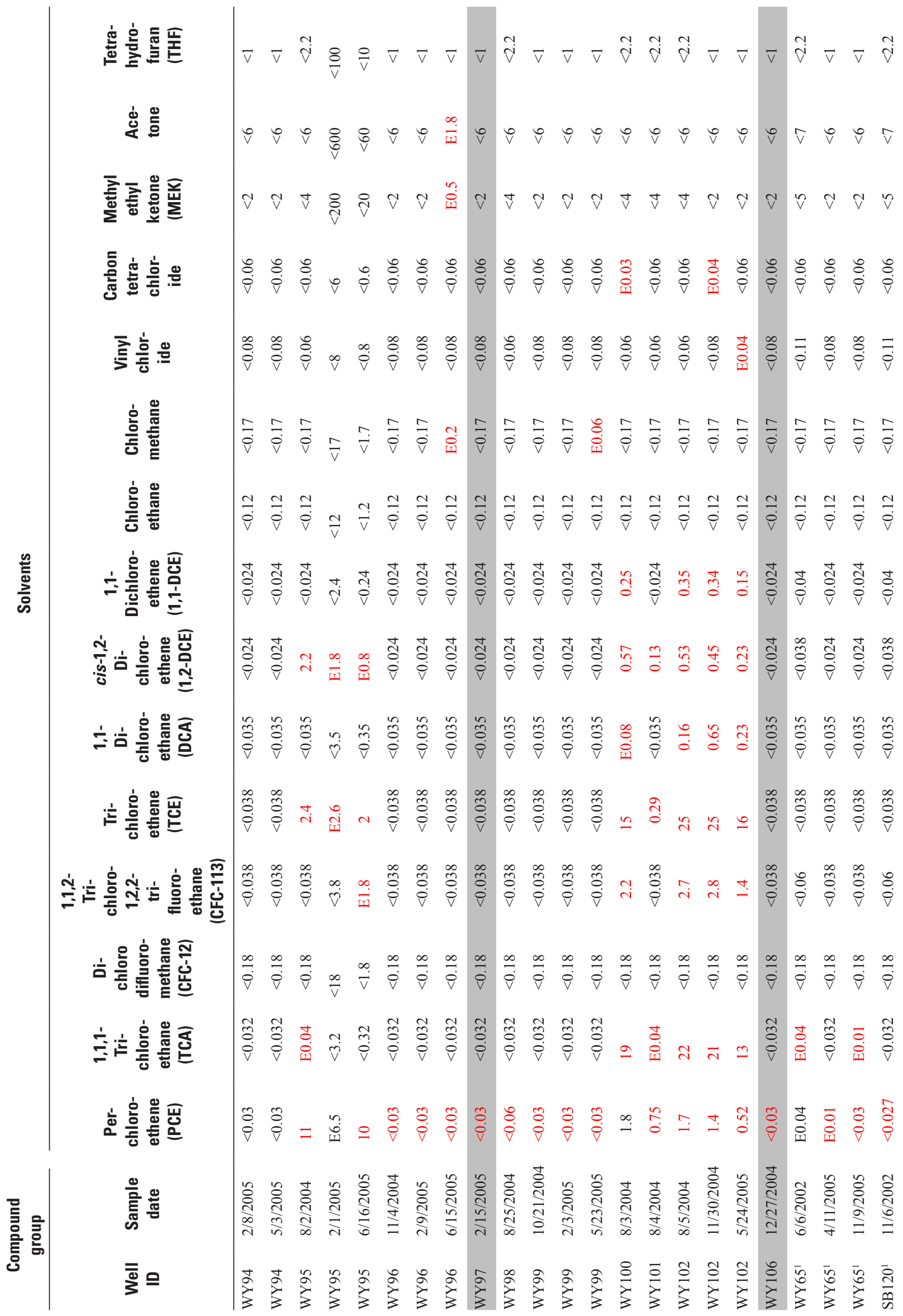




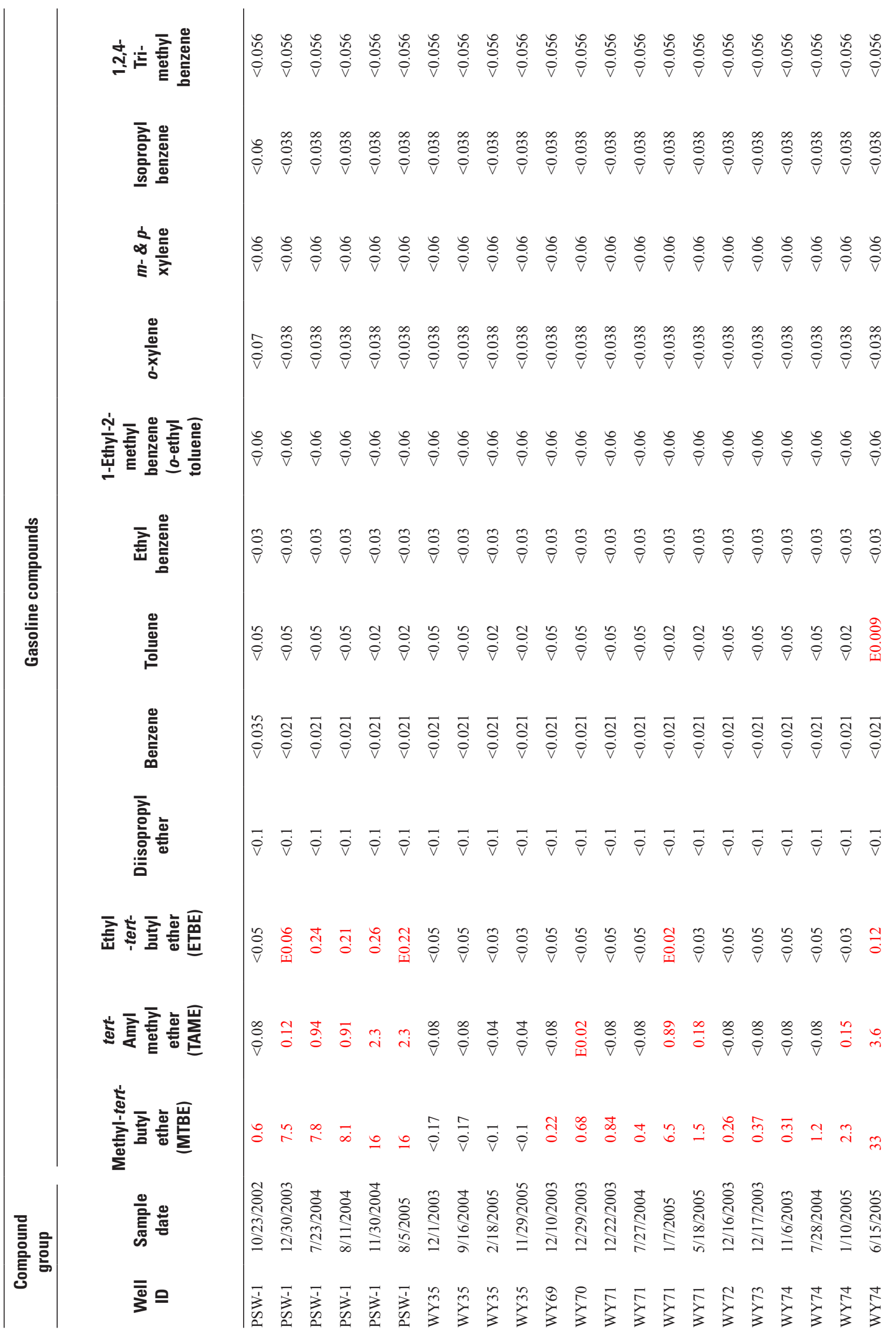




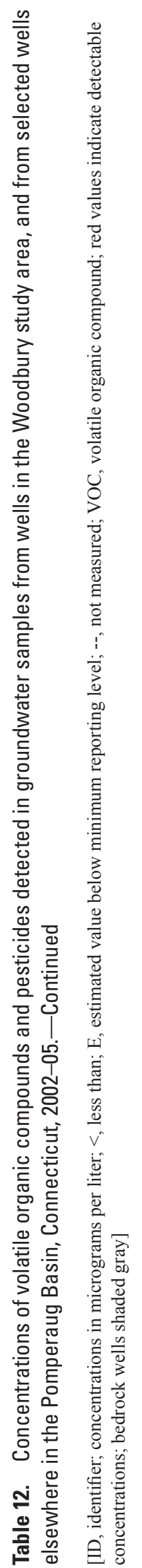

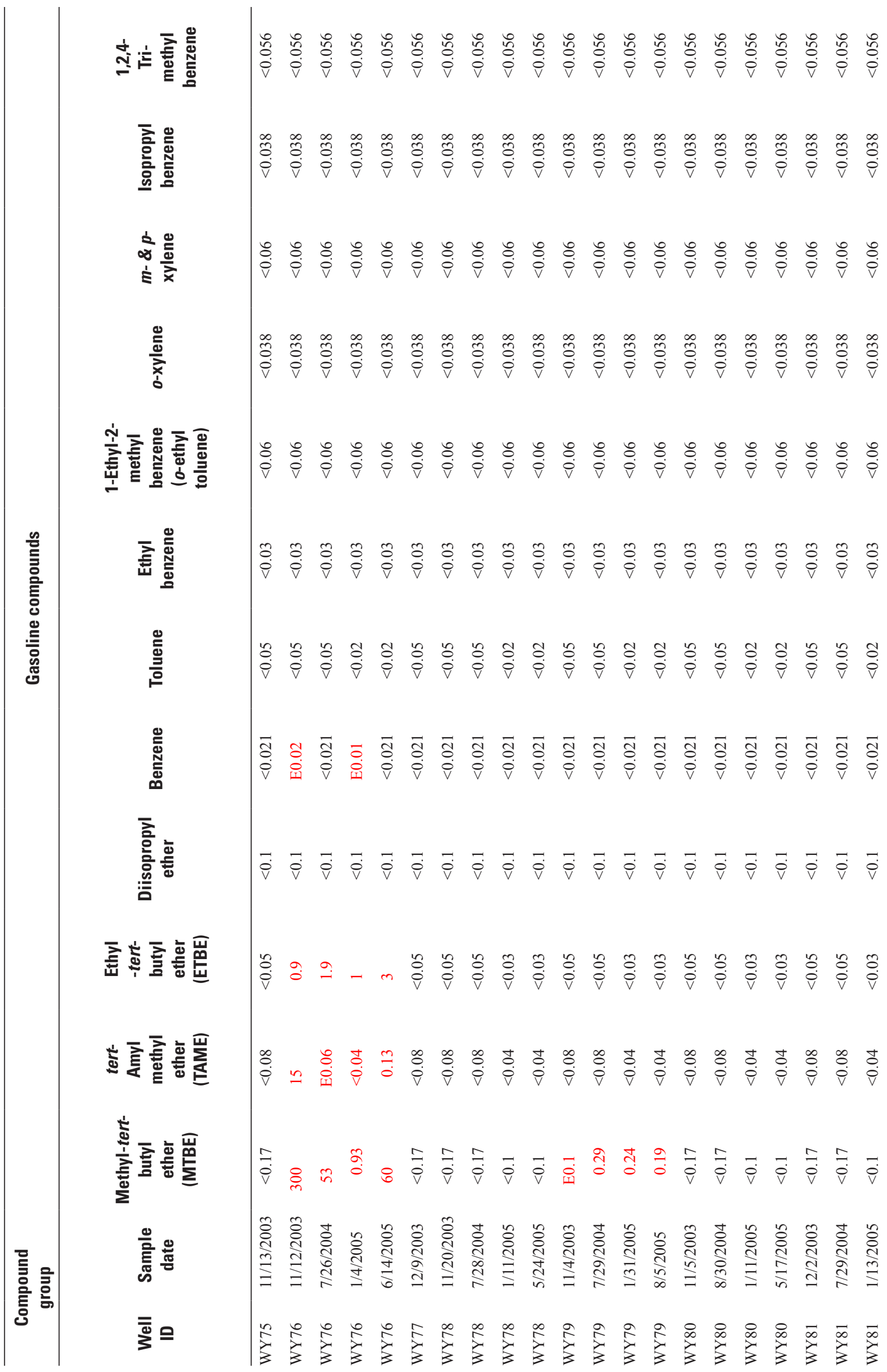




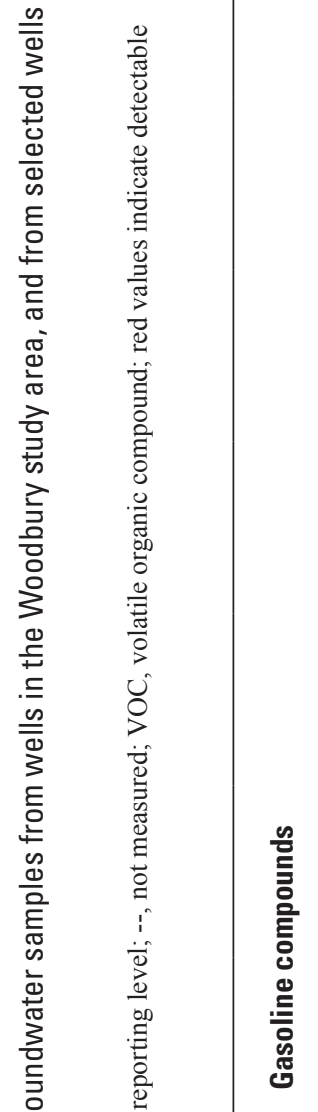

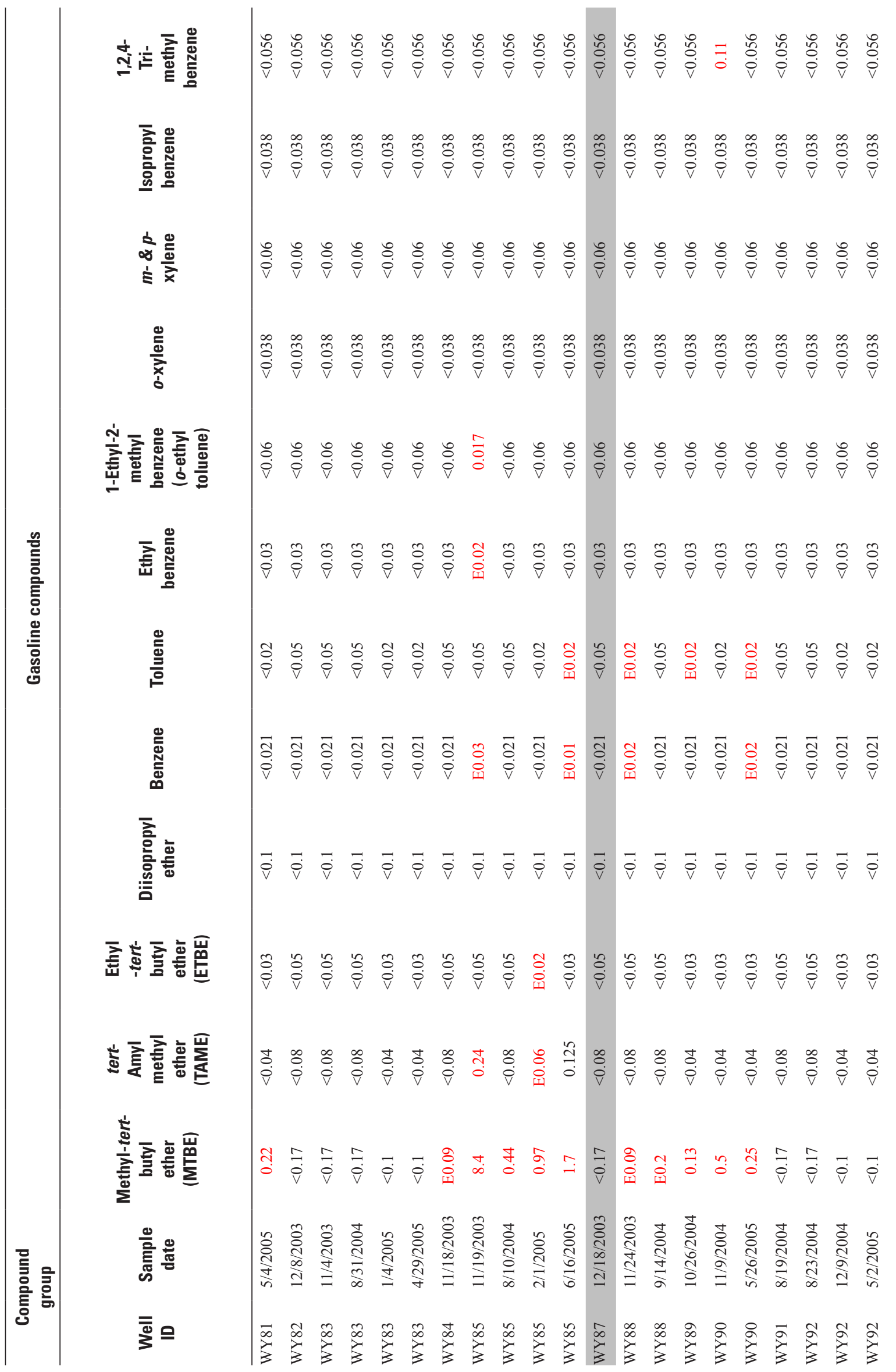




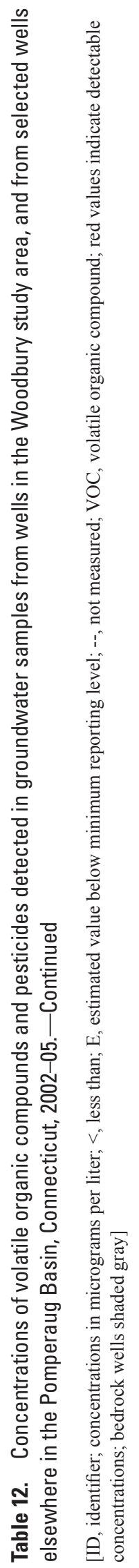

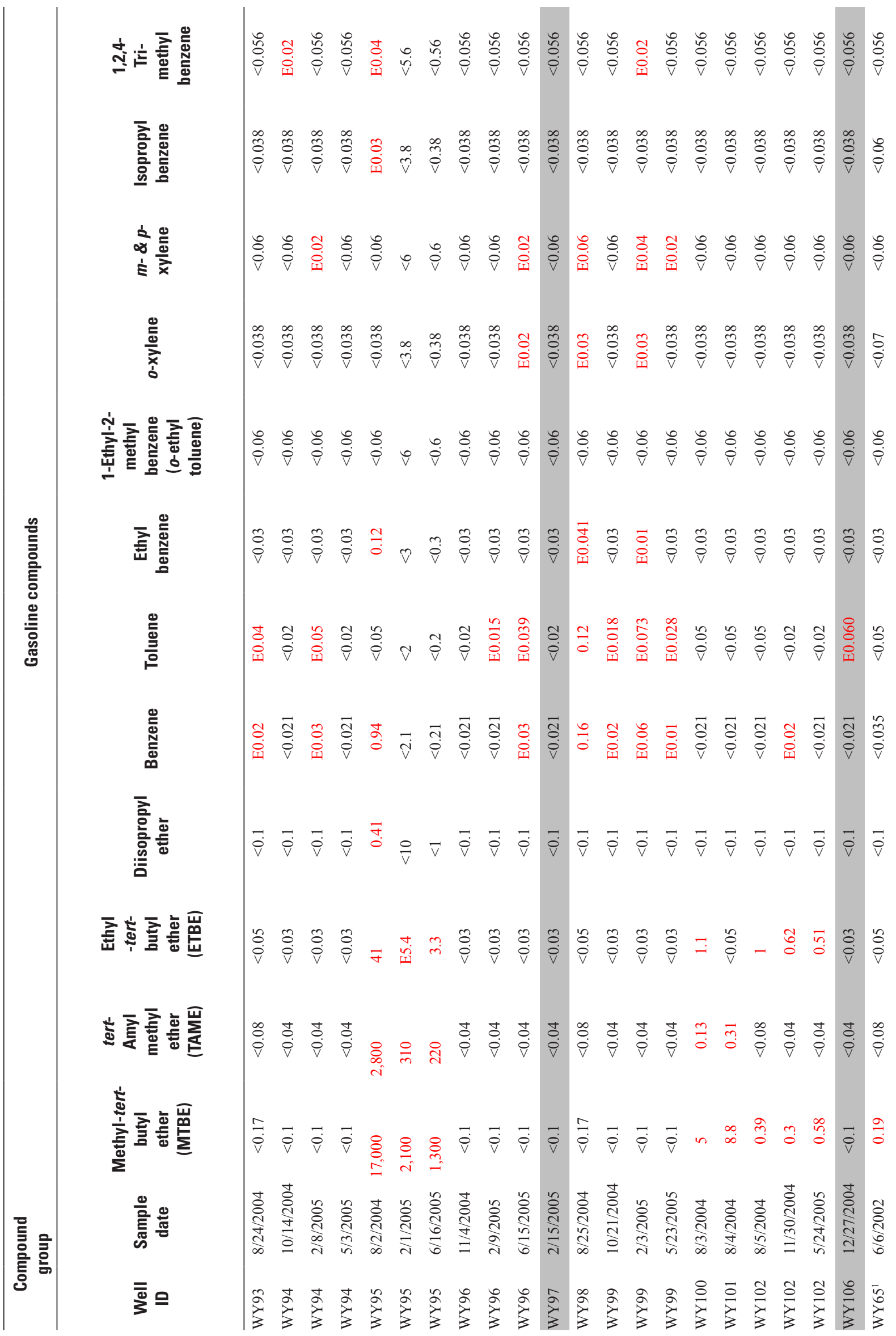




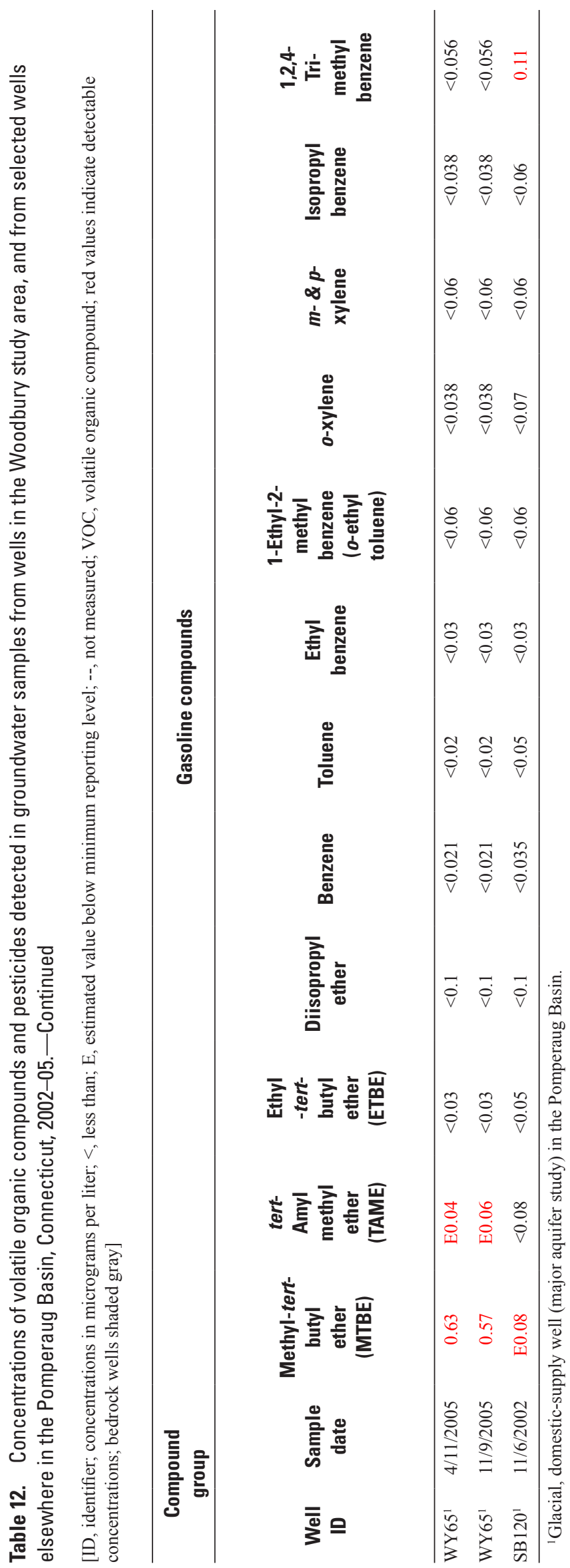




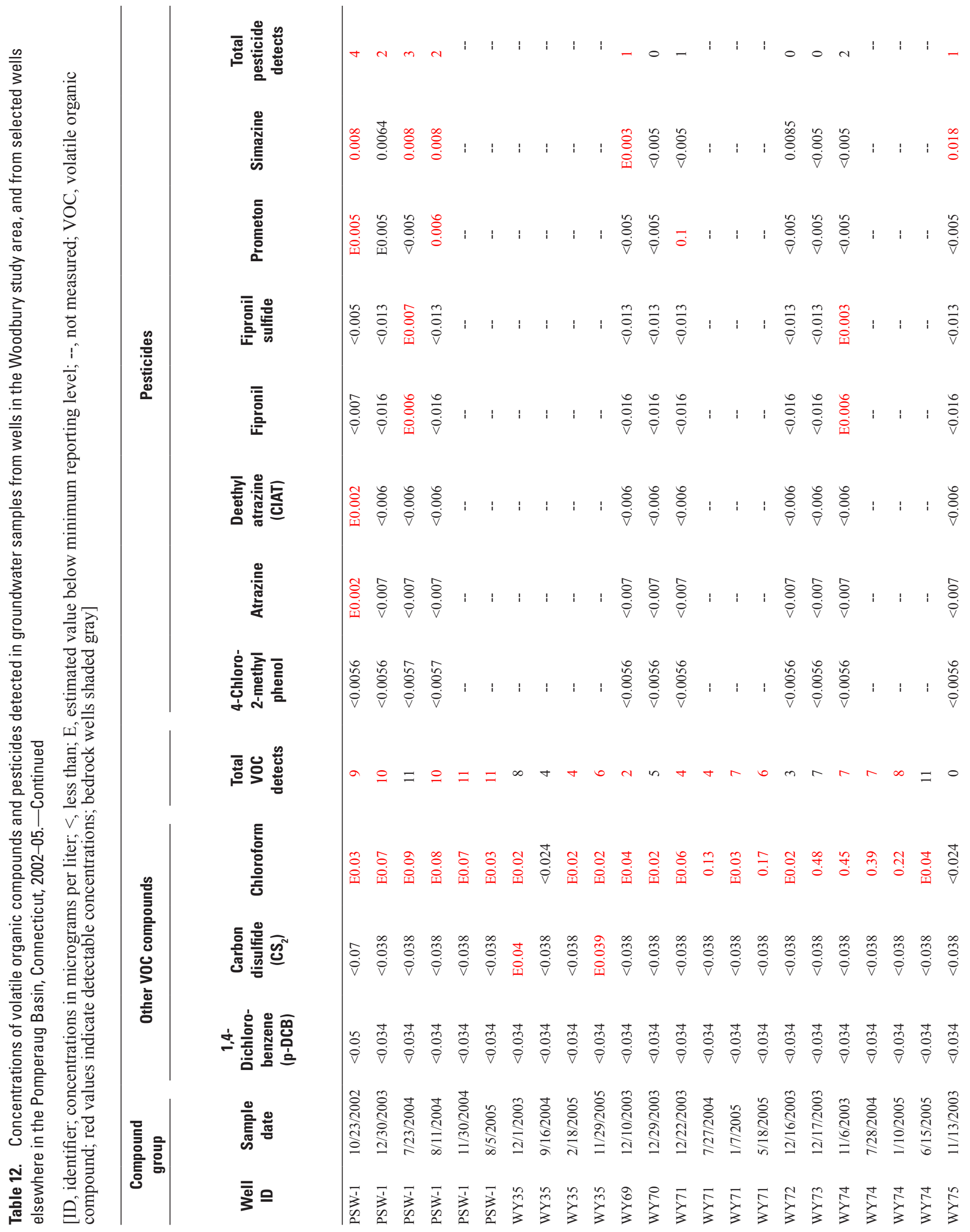




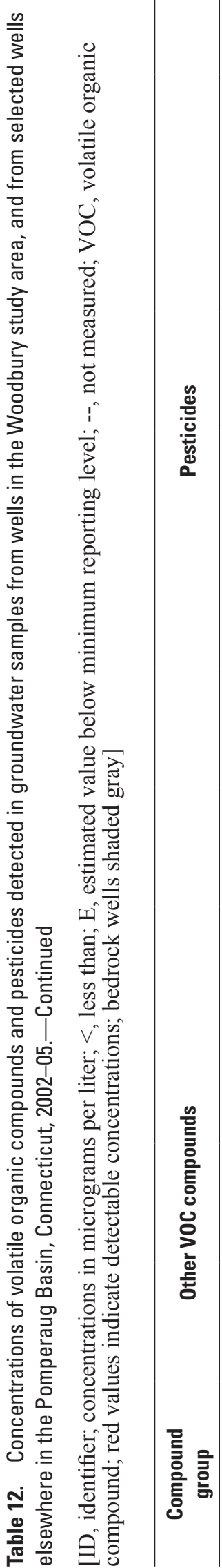

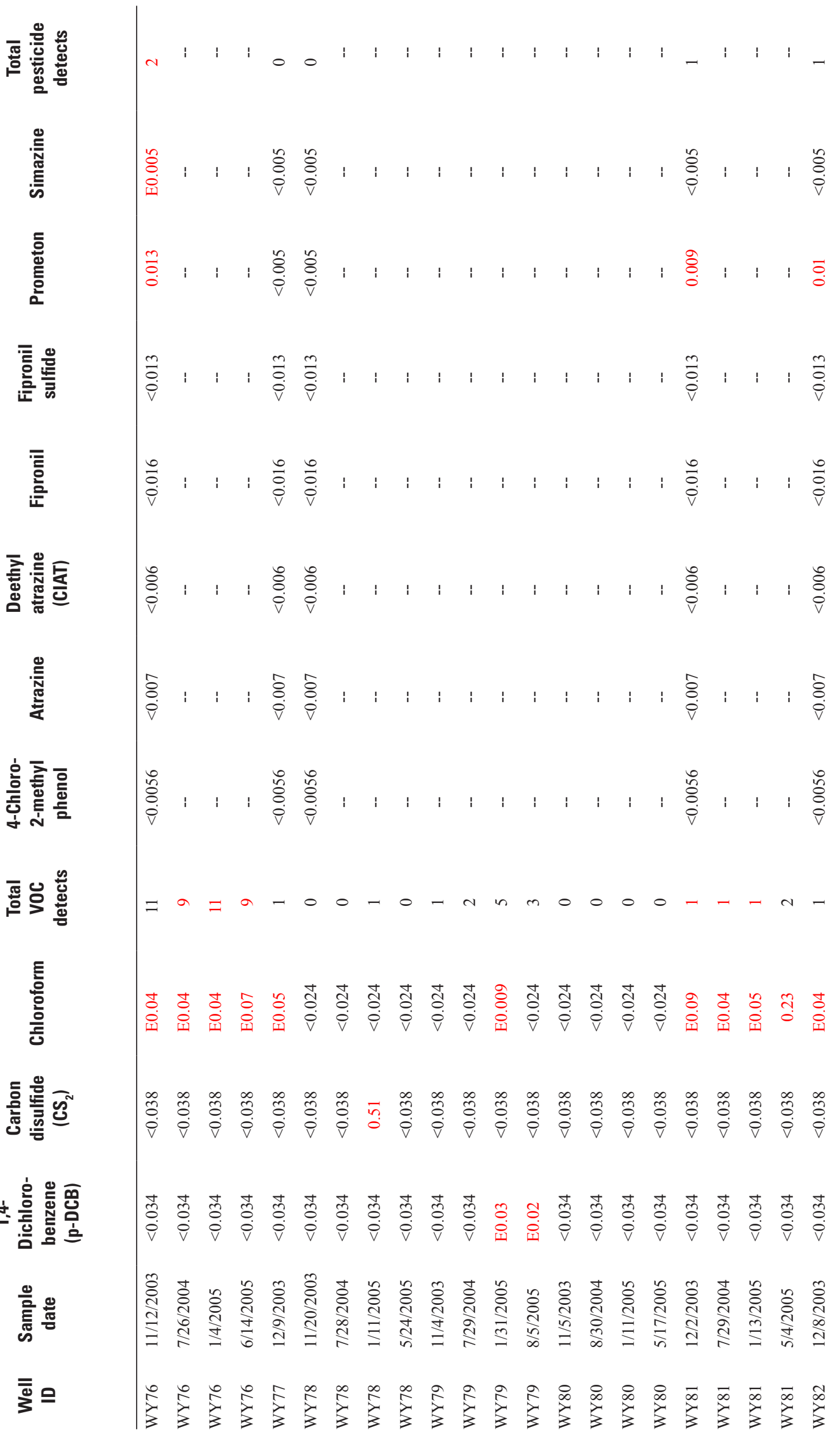



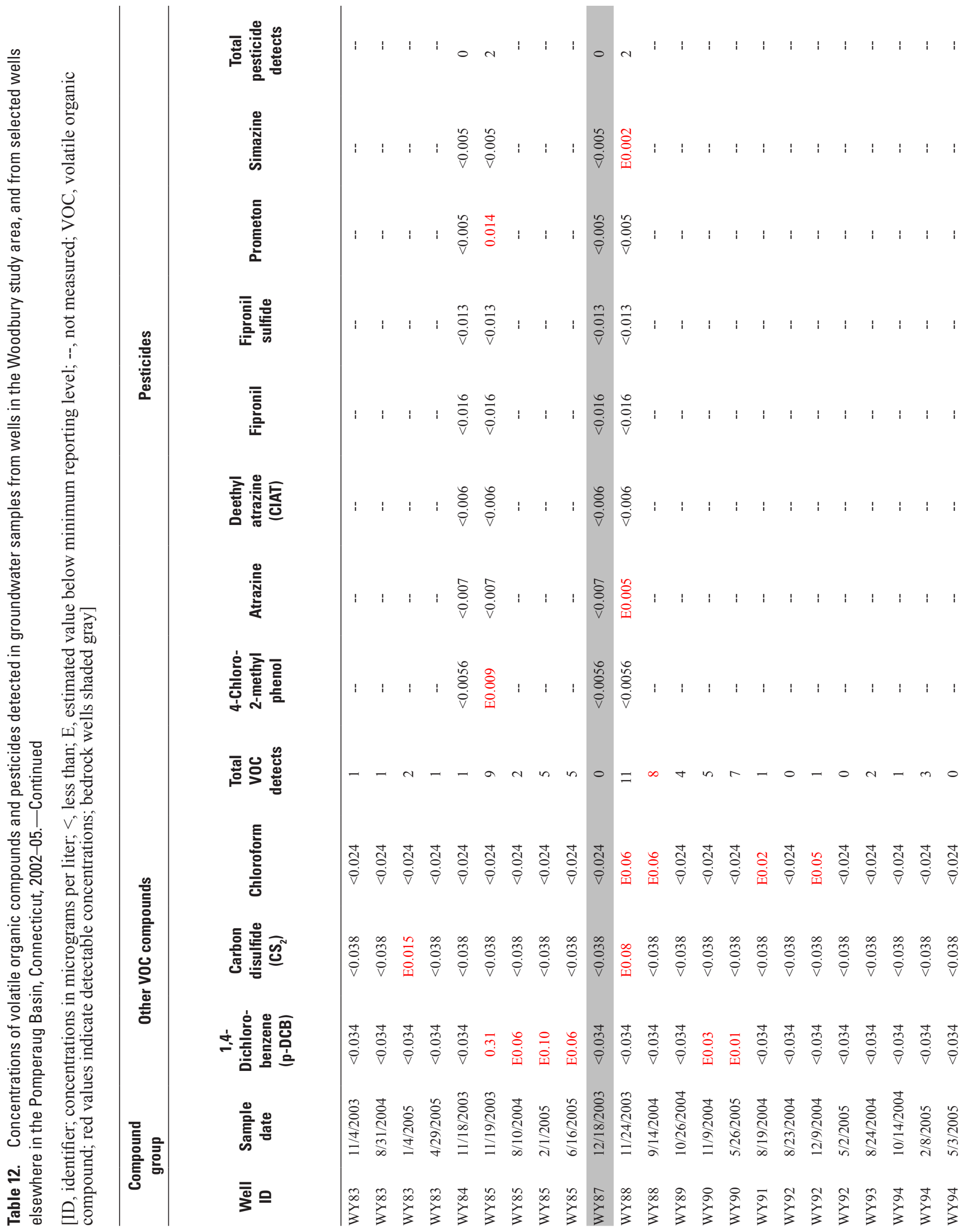

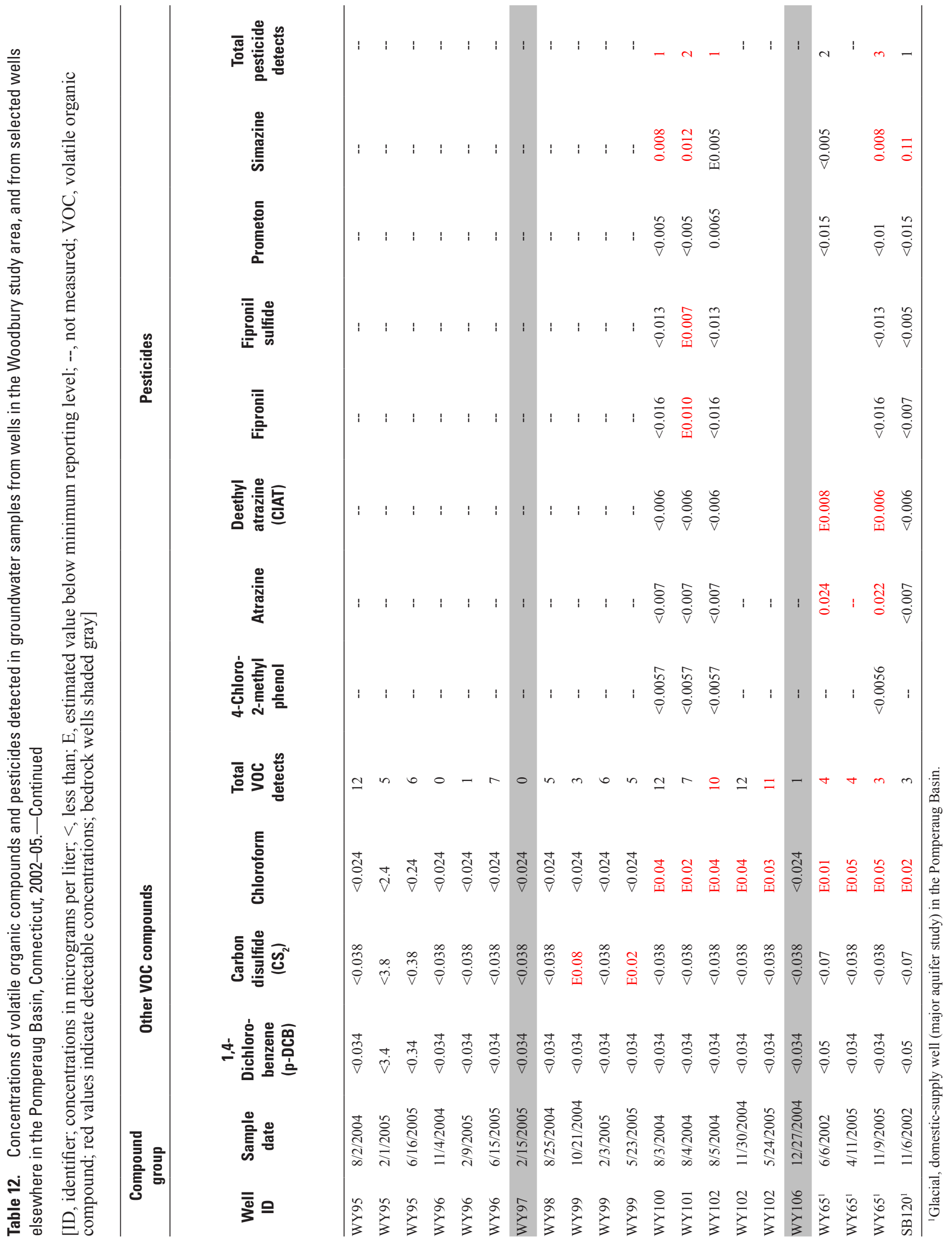


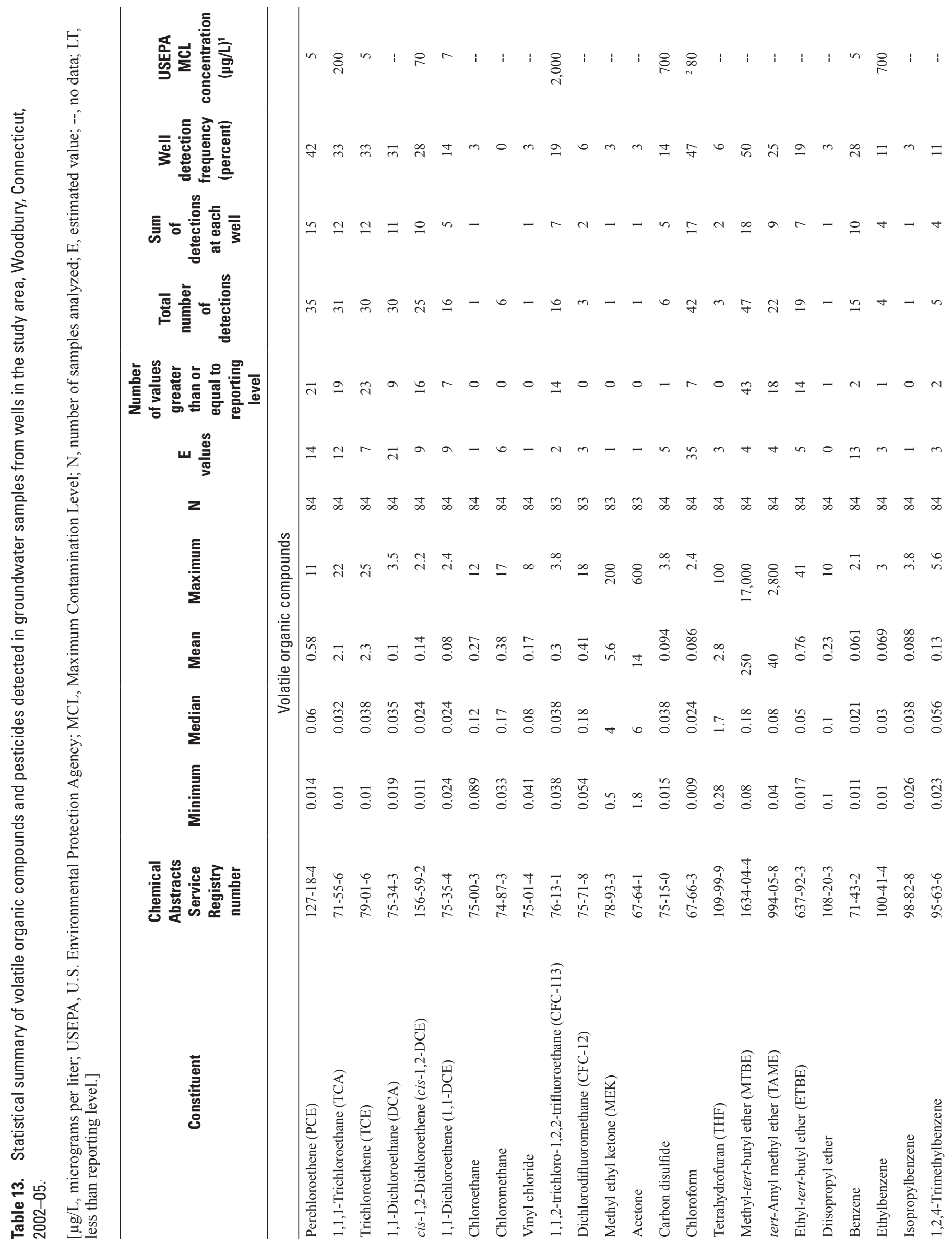




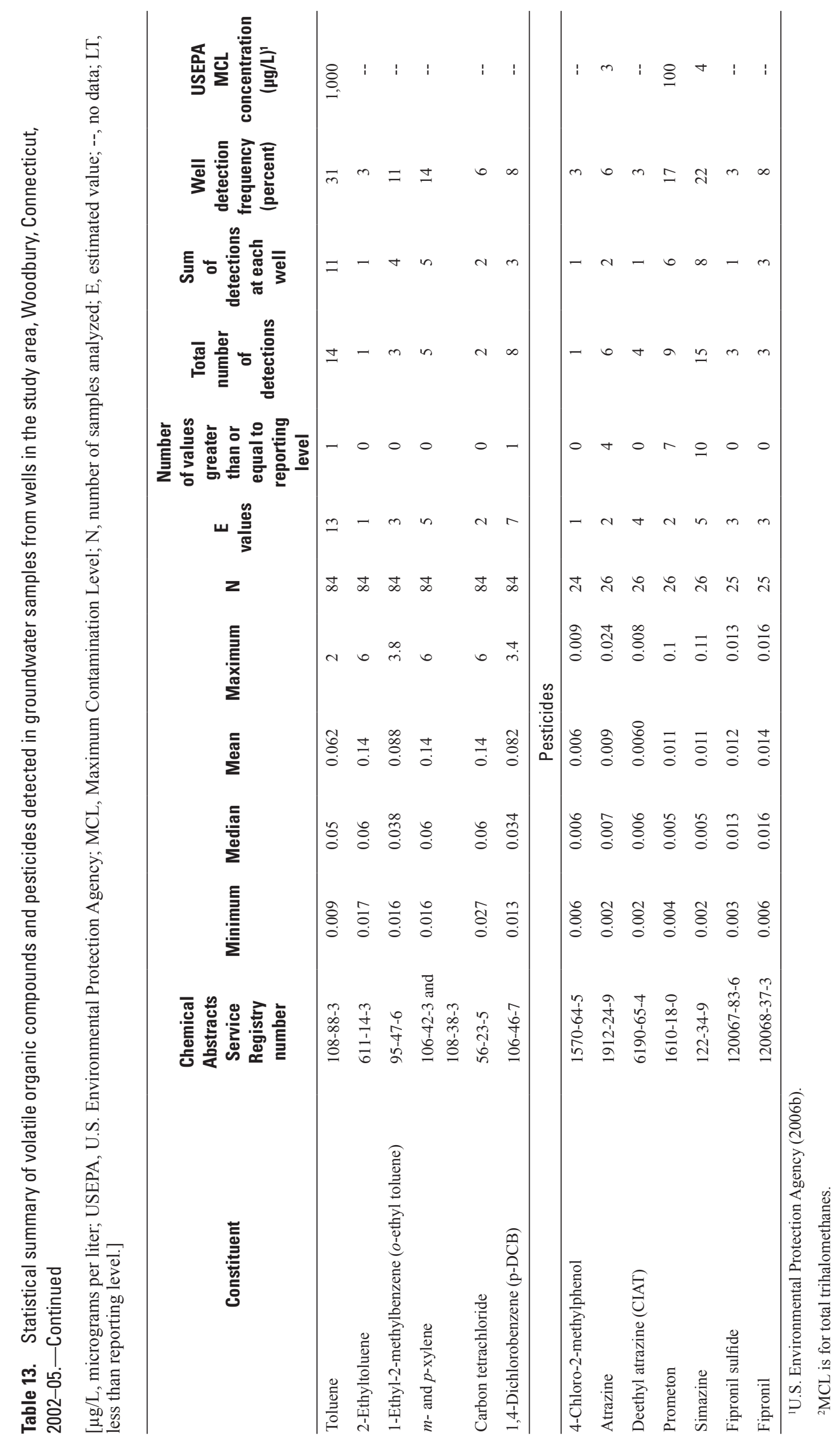



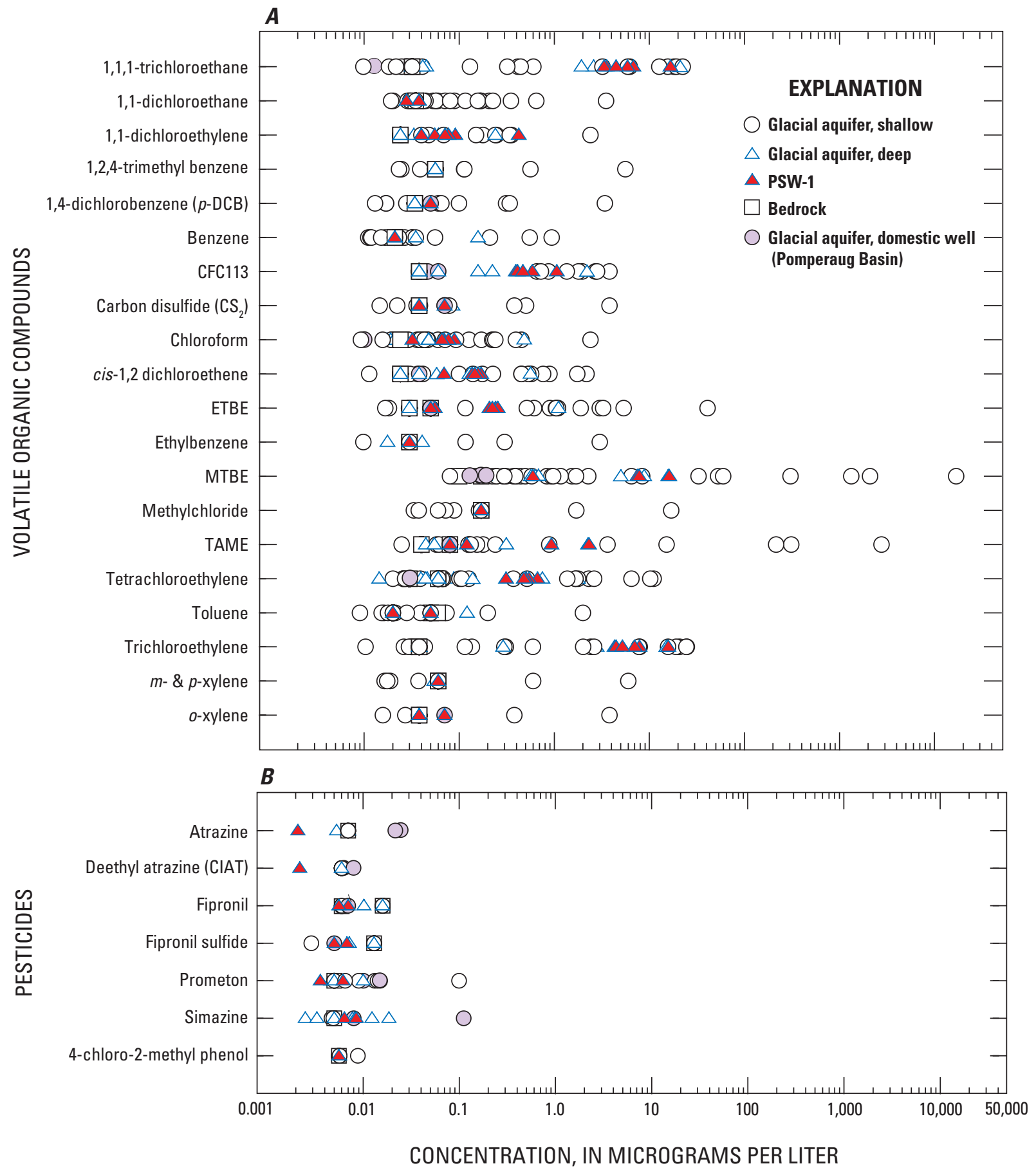

Figure 27. Concentrations of $(A)$ the 20 most frequently detected volatile organic compounds, and $(B)$ the seven most frequently detected pesticides, in groundwater samples from each well site in the Woodbury study area, and from selected wells elsewhere in the Pomperaug Basin, Connecticut. 
2004, to July14, 2006, when the concentration of MTBE in the influent was less than $100 \mu \mathrm{g} / \mathrm{L}$. Concentrations of MTBE in groundwater from PSW-1 had decreased to less than $2 \mu \mathrm{g} / \mathrm{L}$ by July 2006 (Scott Beals, Sovereign Consulting, Inc., written commun., 2007).

Volatile organic compounds can result from industrial production for use in industrial, commercial, or domestic applications but also can originate from transformation in the environment of parent VOC compounds. These productionand domestic-use sources, as well as environmental transformations, likely are sources of the 30 VOCs detected in this study area. Possible transformation byproducts include (1) TCE and 1,2-DCE from PCE; (2) 1,1-DCA from TCA; (3) 1,2-DCE, 1,1-DCE, and vinyl chloride from TCE (Gillham, 1996). Benzene was detected at concentrations up to 9,200 $\mu \mathrm{g} / \mathrm{L}$ at the source of the gasoline spill (discussed previously in this section). The four-fold decrease in benzene concentrations over the $180 \mathrm{~m}$ distance to WY95 indicates a loss rate of 56 $\mu \mathrm{g} / \mathrm{L}$ per $\mathrm{m}$, and that of MTBE yields a loss rate of about 0.19 $\mu \mathrm{g} / \mathrm{L}$ per $\mathrm{m}$. Tetrahydrofuran was detected at concentrations near the MRL at WY35, located in an industrial setting, and at well WY85, located downgradient from a restaurant septictank drainfield in a commercial area. Tetrahydrofuran is a moderately polar solvent that is used in production of food storage and packaging materials, rubber, resins, and plastics. It commonly is used in industry to degrease metal parts, so its uses appear to be consistent with the different source areas where it occurs. Carbon disulfide $\left(\mathrm{CS}_{2}\right)$ was detected in water samples from wells WY35, 88, 78, 83, and 99, where naturally occurring DOC was likely present under sometimes $\mathrm{Fe}$ - or Mn-reducing conditions in sediments adjacent to the well screen. Small amounts of $\mathrm{CS}_{2}$ can be released by the degradation of organic matter in wetlands, although the highest concentrations of $\mathrm{CS}_{2}$ occur near industrial or commercial sources. $\mathrm{CS}_{2}$ also is used in soil disinfectants, herbicides, and grain fumigants (Montgomery and Welkom, 1990).

\section{Pesticides}

Pesticide concentrations were low and generally at or near the MRL. Eight pesticides were detected at low concentrations in groundwater samples: atrazine, deethylatrazine (CIAT, an atrazine breakdown product or degradate), prometon, simazine, 1,4-dichlorobenzene (p-DCB), 4-chloro-2-methylphenol, fipronil, and fipronil sulfide (table 12; fig. 27). Six of these compounds were detected in water samples from PSW-1 (table 12). Concentrations of atrazine in groundwater were much less than $3 \mu \mathrm{g} / \mathrm{L}$, which is the MCL (USEPA, 2006a). Atrazine is an herbicide most commonly detected in agricultural areas but also is used on lawns and golf courses, and along roads and rights-of-way (Gilliom and others, 2006); it can persist in groundwater for long periods of time (Denver and Sandstrom, 1991; Barbash and others, 1999). Prometon and simazine are usually associated with urban herbicides and are applied to lawns, roadsides and other rights-of-way, and nurseries. Fipronil is used as a household insecticide in flea and tick sprays, ant and roach baits, and granular turf products (USEPA, 1996). The compound 4-chloro-2-methylphenol, which is a transformation product of the herbicide 2-methyl-4-chlorophenoxyacetic acid (MCPA), was detected in well WY85.

Atrazine was detected in only a few wells, probably because there is little agricultural land use in the study area. A measure of an organic compound's hydrophobicity is expressed by reporting a coefficient $\mathrm{K}$ that indicates the compound's octanol/water partition coefficient $\left(\mathrm{K}_{\text {ow }}\right)$, which is the ratio of a chemical's concentration in the octanol phase to its concentration in the aqueous phase of a two-phase octanol/water system. Atrazine is considered to be highly mobile and has a $\log \mathrm{K}_{\mathrm{ow}}$ of 2.75 (MacKay and others, 1997). The atrazine transformation product, CIAT, has a $\log \mathrm{K}_{\text {ow }}$ of 1.3 (Gilliom and others, 2006) and also was not widely detected. Prometon and simazine are highly soluble and mobile in water (Gilliom and others, 2006) and were detected at low concentrations in both shallow and deep glacial wells downgradient from the commercial area, whereas atrazine was detected above the MRL at only one site (WY65) near a horse paddock north of the study area. Fipronil adsorbs strongly to soil and has low-to-moderate solubility in water $\left(\mathrm{K}_{\mathrm{ow}}=4.01\right.$; Connelly, 2001) but was detected at estimated values less than the MRL in samples from PSW-1, an adjacent monitoring well, WY101 and a nearby shallow well WY74. Fipronil sulfide is a transformation product of fipronil that has a relatively low mobility. Shallow wells downgradient from commercial or community-residential septic-tank drainfields, including WY79, 85, and 90, had detections of p-DCB, which is used to control moths, molds, and mildew, and to deodorize restrooms and waste containers. Twenty-two percent of its production is for use as a deodorant in toilet blocks, and 28 percent is for use as a moth repellent (Agency for Toxic Substances and Disease Registry, 2006). The leachate from septic-tank drainfields that are upgradient from the wells in which p-DCB was detected originates from buildings where professional cleaning services or supplies are used and likely contains this compound. p-DCB is a possible carcinogen, although there is no direct evidence that it can cause cancer in humans (Norris, 1997).

\section{Groundwater Age}

Samples were collected to estimate groundwater ages using several tracers, including (1) ${ }^{3} \mathrm{H},(2){ }^{3} \mathrm{H}-{ }^{3} \mathrm{He}$, (3) $\mathrm{SF}_{6}$, and (4) chlorofluorocarbons (CFCs). Apparent groundwater age is defined as the time elapsed since recharge of a sampled parcel of water. ${ }^{3} \mathrm{H}$ was measured for several wells, in addition to those sampled for ${ }^{3} \mathrm{H}-{ }^{3} \mathrm{H}$, to determine whether the water was prenuclear detonation (or prebomb) in age and recharged before 1952, or postbomb in age. Dissolved gas concentrations were measured to estimate the temperature of groundwater 
at the time of recharge, because the solubility of atmospheric tracers varies as a function of temperature, and to calculate the amount of excess air and excess $\mathrm{N}$ (table 11).

Recharge temperatures were estimated from $\mathrm{Ne}, \mathrm{Ar}$, and $\mathrm{N}_{2}$ dissolved gas concentrations and yielded an average of $9.0^{\circ} \mathrm{C}$; average excess air volume was $2.2 \mathrm{~cm}^{3} / \mathrm{L}$ at standard temperature and pressure $\left(\mathrm{cm}^{3} \mathrm{STP} / \mathrm{L}\right)$ (table 11). The estimated recharge temperature varied in PSW-1 between the two sampling years, as indicated by the range in recharge temperatures $\left(7.8\right.$ to $10.6^{\circ} \mathrm{C}$ ) (table 11). Recharge temperatures in shallow wells averaged $10.2^{\circ} \mathrm{C}$ with $2 \mathrm{~cm}^{3} \mathrm{STP} / \mathrm{L}$ of excess air, and those in the deep glacial, upland till, and bedrock wells averaged $8.1^{\circ} \mathrm{C}$ with $2.3 \mathrm{~cm}^{3} \mathrm{STP} / \mathrm{L}$ excess air. In addition to this stratification in groundwater temperatures, there is an inverse relationship between apparent groundwater age and recharge temperature (fig. 28A). There are three possible reasons for the differences in recharge temperatures. (1) Groundwater recharge from stormwater runoff over pavement and other impervious surfaces and from septic-tank drainfields in the relatively urbanized valley bottom would generally be warmer than water recharged in upland areas. Water from shallow wells can be very young ( 0 to 2 years) and, because many of the dissolved gas samples were collected during the fall, may reflect warmer temperatures, especially in areas of overland flow (warm pavement) and septic-tank drainfields. Furthermore, recharge temperatures in shallow groundwater were affected locally in some wells by streamflow leakage to groundwater during warmer months. (2) A greater percentage of recharge may occur in the uplands during the winter and spring, compared to that in the valley bottom. The uplands are predominantly forested, and soils are generally more porous on the forest floor and could allow more infiltration compared to cleared and compacted developed land at the valley bottom, even during winter months (Satterlund and Adams, 1992). (3) Air temperatures have warmed over the past 150 years (Jones and others, 1999) and older groundwater was recharged at colder temperatures. This is consistent with the decrease in $\delta^{18} \mathrm{O}$ and $\delta \mathrm{D}$ values observed with increasing groundwater age (fig. 25A and table 8).

The amount of excess air calculated from dissolved gases also varied among wells and was larger in bedrock wells, and in wells WY81 and 82, which have recent recharge. Well WY85 appeared to be stripped of some dissolved gases, based on the ratios of $\mathrm{N}_{2}, \mathrm{Ar}$, and Ne. Gas stripping in groundwater at WY85, and possibly the deeper well WY84, could result from $\mathrm{CH}_{4}, \mathrm{H}_{2} \mathrm{~S}$, and $\mathrm{N}_{2}$ gas bubbles rising through sediments as a result of natural microbial processes associated with the decomposition of septic-system leachate. Two other wells, WY89 and WY90, are immediately downgradient from a septic-tank drainfield. Excess $\mathrm{N}_{2}$ amounts were estimated for these wells, as discussed in section "Collection and Analysis of Water Samples," because it is very likely that the conversion of $\mathrm{NO}_{3}^{-}$to $\mathrm{N}_{2}$ occurred here, given the low DO concentrations, the high DOC concentrations, and the low concentrations of $\mathrm{NO}_{3}^{-}$. Well WY79 had excess $\mathrm{N}_{2}$ amounts and is located in a town park where fertilizer $\mathrm{N}$ is a likely source. Organic-rich glacial sediments derived from the Cass Formation also could create the low DO concentrations near the well (table 7).

Dating groundwater with ${ }^{3} \mathrm{H}$ is qualitative at best, but can be useful in recognizing postbomb water, and can be used together with other tracers to estimate mixing of groundwater from various sources. ${ }^{3} \mathrm{H}$ concentrations in samples from wells screened in glacial deposits ranged from 6.0 tritium units (TU) in well WY102 to $7.5 \mathrm{TU}$ in WY76 (table 14). These ranges in values reflect, in part, the high seasonal and annual variations observed in ${ }^{3} \mathrm{H}$ in precipitation (Clark and Fritz, 1997). The ${ }^{3} \mathrm{H}$ concentration in a sample from a bedrock well WY106 was $0.10 \mathrm{TU}$, indicating that the water likely was recharged before 1952.

The ${ }^{3} \mathrm{H} /{ }^{3} \mathrm{He}$ dates were estimated in 18 samples from 17 wells (PSW-1 was sampled twice). Apparent age in groundwater is less than 6 years in most glacial aquifer deposits, but older in bedrock groundwater, which flows through fractures that require longer or slower flow paths (fig. 28A). Apparent groundwater ages in the glacial aquifer ranged from 0.7 years in a shallow well near PSW-1 to 8.4 years in a deep well about midway along the flow path in overlying glacial deposits. Apparent ages in groundwater from shallow bedrock wells (less than $15 \mathrm{~m}$ below bedrock surface) ranged from 9.9 to over 20 years. Well WY87, which intersects a fracture in basalt, had an apparent age of 9.9 years, which is longer than the mean simulated age of 2.6 years (tables 9 and 14). The measured residence time can be long for at least two reasons: (1) the actual flow path can be longer than the simulated flow path because of tortuous paths through a fracture network (fracture networks are not explicitly included in the simulation), or (2) the sample is a mixture of water of a short residence time (through a permeable fracture) and water of a long residence time (from dead-end fractures or from fractures so small that Darcy's Law does not apply) (Starn and Brown, 2007). The simulated residence times in bedrock tend to be short because of the low bulk-rock porosity that is used in the advective particle tracking.

The ${ }^{3} \mathrm{H}-{ }^{3} \mathrm{He}$ apparent-age calculations are sensitive to the amount of terrigenic ${ }^{4} \mathrm{He}$ (from decay of U-series radionuclides) and excess air. Terrigenic ${ }^{4} \mathrm{He}$ is naturally derived from crystalline rock sources (Plummer and others, 2003) and excesses of even 50 percent over that of air-water equilibrium can invalidate or create large uncertainties in ${ }^{3} \mathrm{H}-{ }^{3} \mathrm{He}$ dating, such as in areas where the old fraction contains mixed mantle and crustal helium sources (Plummer and others, 2000). Terrigenic ${ }^{4} \mathrm{He}$ (relative to the total ${ }^{4} \mathrm{He}$ ) generally was high (greater than 15 percent) and water samples from bedrock wells WY86, WY97, and WY106 had exceedingly high percentages of terrigenic He that precluded determination of ages (table 14). The ${ }^{4} \mathrm{He}$ concentrations also were high in samples from glacial sediments, possibly from decay of $\mathrm{U}$-series radionuclides in sand grains ( $\mathrm{Fe}$ oxides or feldspars) that originated from crystalline rock in the uplands. This explanation is supported by an increase of excess ${ }^{4} \mathrm{He}$ 

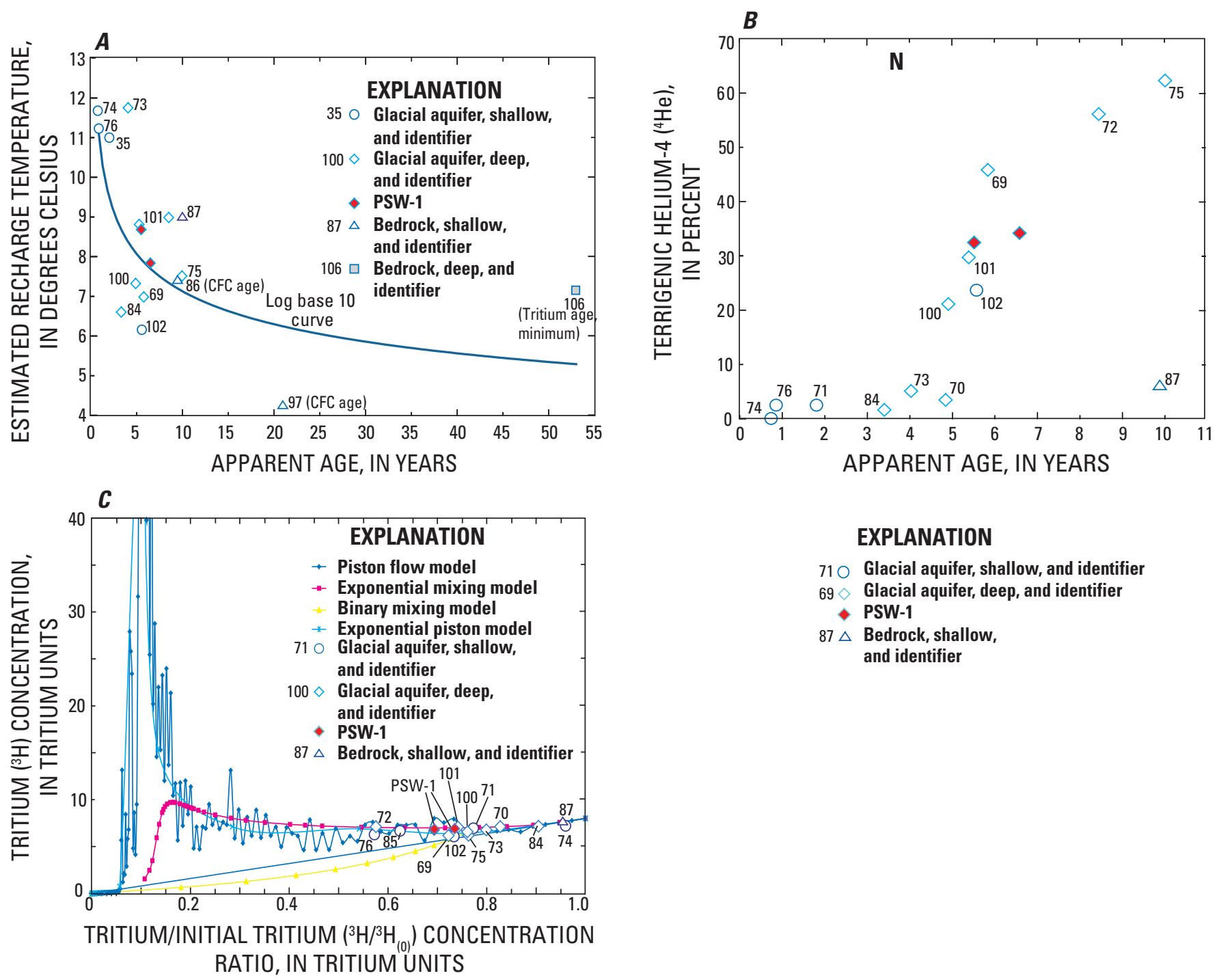

\section{EXPLANATION}

710 Glacial aquifer, shallow, and identifier

$69 \diamond$ Glacial aquifer, deep, and identifier

- PSW-1

$87 \Delta$ Bedrock, shallow, and identifier

Figure 28. (A) Apparent groundwater age as a function of estimated groundwater recharge temperature, $(B)$ apparent groundwater age as a function of terrigenic helium-4 $\left({ }^{4} \mathrm{He}\right)$ percentage, and $(C)$ the tritium/initial tritium $\left({ }^{3} \mathrm{H} /{ }^{3} \mathrm{H}_{(0)}\right)$ concentration ratio plotted as a function of concentrations of helium-3 $\left({ }^{3} \mathrm{H}\right)$, with modeled curves for various groundwater age distributions for groundwater samples from wells in the study area, Woodbury, Connecticut.

concentration with age (fig. 28B); ${ }^{4} \mathrm{He}$ concentrations are lower in younger groundwater (less than 7 years in age), and He apparently accumulates from U-series decay in aquifer sediments. In addition, temperature correlates with excess ${ }^{4} \mathrm{He}$; samples with high excess ${ }^{4} \mathrm{He}$ typically had cooler recharge temperatures, whereas young samples had warmer temperatures (for example, WY74 and WY76). Samples with a negative percent terrigenic ${ }^{4} \mathrm{He}$, including those collected from wells WY74, WY84, and WY85 (table 14), may indicate gas stripping, which could result in preferential loss of ${ }^{3} \mathrm{He}$ and yield an older estimated age.

Lumped parameter models were used to estimate the mean residence time and age distribution of groundwater in the glacial aquifer and the underlying fractured bedrock.
These models treat an aquifer system as a homogeneous compartment in which the input tracer concentrations are converted to output tracer concentrations according to the system-response function used and how the flow system is described (Zuber, 1986; Maloszewski and Zuber, 1982). Flowsystem characteristics are represented by assumed conceptual end members, including a piston-flow model (PFM), an exponential-mixing model (EMM), and a binary-mixing model (BMM) (Cook and Böhlke, 1999) (fig. 28C). For the PFM, it is assumed that after a tracer is isolated from the atmosphere (at the time of groundwater recharge), it becomes incorporated in a parcel of water that moves from the recharge area with the mean velocity of groundwater. All flow lines are assumed to have similar velocities, and hydrodynamic dispersion and 
molecular diffusion of the tracer are assumed to be negligible. The BMM assumes that one or both end members of the binary mixture is either young or old. The EMM represents an aquifer system in which the mean residence time of groundwater is exponentially distributed. Groundwater flow is composed of recharge from all past years, but contributions to well discharge decrease exponentially from the most recent recharge to that which took place in the very distant past. In the exponential-piston model (EPM), the sample consists of an infinite number of subparcels that have an exponential age distribution (EMM), but the whole assemblage is shifted in time (Cook and Böhlke, 1999).

A computer program (Böhlke, 2005) was used to calculate theoretical curves for the different lumped parameter models using atmospheric data as input for the various tracers. ${ }^{3} \mathrm{H}_{(0)}$ represents the initial ${ }^{3} \mathrm{H}$ concentration at the time of recharge and is the sum of the measured concentrations of ${ }^{3} \mathrm{H}$ and tritiogenic ${ }^{3} \mathrm{He}$. A graph of the relation between ${ }^{3} \mathrm{H} /{ }^{3} \mathrm{H}_{(0)}$ and ${ }^{3} \mathrm{H}$ (fig. 28C) shows that most well samples generally plot along the PFM curve for very young water (less than 6 years in age), although samples from two deep wells (WY69 and WY75) and WY102, a shallow well near PSW-1, plot on or near the BMM curve dominated by young water (fig. 28C). The fit of samples to the BMM curve supports earlier evidence that a small proportion of the sample may be tracer-free water derived from the underlying bedrock. The ${ }^{3} \mathrm{H}-{ }^{3} \mathrm{He}$ apparent ages of deep glacial wells generally are older than those of shallow wells; Starn and Brown (2007) used simulated agetracer distributions to explain that about 34 percent of the flow in glacial deposits at the study area was derived from underlying bedrock.

A graph of ${ }^{3} \mathrm{H}^{3} \mathrm{H}_{(0)}$ and $\mathrm{SF}_{6}$ concentrations (fig. 29A) shows the relatively high concentrations of the $\mathrm{SF}_{6}$ tracer relative to the ${ }^{3} \mathrm{H} /{ }^{3} \mathrm{H}_{(0)}$ ratio. The disparity probably results from background $\mathrm{SF}_{6}$ concentrations in glacial deposits that were derived from high-temperature crystalline rocks; as with terrigenic ${ }^{4} \mathrm{He}$, terrigenic $\mathrm{SF}_{6}$ also occurs naturally in some crystalline rocks, mainly as fluid inclusions, and slowly diffuses into the water (Busenberg and Plummer, 2000). Well WY86, which is completed in the crystalline bedrock, had a measured $\mathrm{SF}_{6}$ concentration of more than 19 femtomoles per kilogram (femtomol $/ \mathrm{kg}$ ), whereas the $\mathrm{SF}_{6}$ concentrations in the rest of the samples were generally less than 3 femtomol/ $\mathrm{kg}$ (table 14). Although it seems likely that $\mathrm{SF}_{6}$ concentrations, like terrigenic ${ }^{4} \mathrm{He}$, are naturally high in the glacial deposits derived from crystalline rocks, the correlation is not good between these constituents (fig. 29B). However, the water samples from deep glacial wells that likely are affected by groundwater from bedrock are particularly high in concentrations of $\mathrm{SF}_{6}$ and terrigenic ${ }^{4} \mathrm{He}$ (PSW-1, WY69, WY72, and WY75). Water samples from other wells that are not high in concentrations of terrigenic ${ }^{4} \mathrm{He}$, but do have high concentrations of $\mathrm{SF}_{6}$, may have additional sources (fluid inclusions) in the glacial deposits and, therefore, are not as attenuated as is ${ }^{4} \mathrm{He}$ during transport away from the bedrock source. The $\mathrm{SF}_{6}$ tracer gives a current age of water in most wells and, therefore, was not used for analysis in this study.

Age dating with CFCs was done only in two of the bedrock wells (table 15); the presence of CFCs that originate from spills or tank leaks precluded their use at wells with flow paths underlying or downgradient from commercially developed land. Generally, the apparent ages determined by CFCs are older than those determined by ${ }^{3} \mathrm{H} /{ }^{3} \mathrm{He}$ because the ${ }^{3} \mathrm{H} /{ }^{3} \mathrm{He}$ ages are based on an isotope ratio that should not be affected by mixing with old (pre-1952) water. However, CFCs can be degraded under anaerobic conditions, and the resulting low concentrations indicate artificially old apparent groundwater ages. Based on concentrations of the CFC-12 tracer and using a PFM, groundwater from WY86 has an apparent age of about 8 to 10 years. The CFC-11 and CFC-113 tracers are more prone to degradation under $\mathrm{Fe}$ - and $\mathrm{SO}_{4}{ }^{2-}$ reducing conditions and, on the basis of ratio comparisons to CFC-12, appear to be partially degraded; the low concentrations of DO and detectable amounts of $\mathrm{H}_{2} \mathrm{~S}$ and $\mathrm{CH}_{4}$ measured in samples from this well support the hypothesis that some anaerobic degradation has taken place. CFC-12 is less prone to degradation, so the apparent age could be even younger than 8 to 10 years, especially given the fact that the well exhibits artesian conditions following spring recharge.

WY97 was contaminated with CFC-11, probably from a septic-tank drainfield about $40 \mathrm{~m}$ west of the well, but CFC-12 and $\mathrm{CFC}-113$ indicate an apparent age range of 20 to 22 years.

Groundwater residence times were simulated using MODPATH (table 9), as discussed in section "Major Elements and Nutrients," to help relate natural and anthropogenic factors to water quality because groundwater tracers for which apparent ages can be estimated were not sampled at all wells. The mean simulated flow-weighted residence time of water withdrawn from PSW-1, determined with forward particle tracking, is 5.8 years (Starn and Brown, 2007) and agrees reasonably with the apparent ${ }^{3} \mathrm{H}-{ }^{3} \mathrm{He}$ age of 5.5 and 6.6 years. About 34 percent of the groundwater from PWS-1 corresponds to water recharged in the glacial aquifer and is younger than 5 years, about 56 percent of the water is from 5 to 9 years old, and the remaining 10 percent of the water is older than 9 years and likely was derived from till or upland bedrock, based on model simulations (Starn and Brown, 2007). Vertical profiles of groundwater residence time for water recharged through the valley bottom seem to show superimposed exponential distributions, whereas in deeper parts of the aquifer, which are recharged primarily in the uplands, the vertical profiles show a piston-flow distribution (Starn and Brown, 2007). The wide range of ages in the aquifer is a result of a mixing of many different flow paths, such that age inversions (older water overlying younger water) can occur at several points in the profile.

Groundwater age plotted as a function of the number of VOC detections (fig. 30) indicates that VOC occurrences are related to short groundwater traveltimes, and therefore, young groundwater is more vulnerable to contamination than older groundwater. The exceptions include the samples from PSW-1 
Table 14. Summary of tritium/helium-3 $\left({ }^{3} \mathrm{H} /{ }^{3} \mathrm{He}\right)$, sulfur hexachloride $\left(\mathrm{SF}_{6}\right)$, and chlorofluorocarbons $(\mathrm{CFC})$ groundwater age tracer data and apparent ages using a piston flow model for water samples in the study area, Woodbury, Connecticut, 2003-2005.

[Ages in bold are deemed most reliable; ID, identifier; NP, not possible to calculate an age; --, not measured; $\mathrm{cm}^{3} \mathrm{STP} / \mathrm{gH}_{2} \mathrm{O}$, cubic centimeters per gram of water at standard temperature and pressure; TU, tritium units; femtoMol $/ \mathrm{kg}$, femtomoles per kilogram; pmol/kg, picomoles per kilogram; pptv, parts per trillion by volume; bedrock wells shaded gray]

\begin{tabular}{|c|c|c|c|c|c|c|c|c|c|}
\hline \multirow[b]{2}{*}{$\begin{array}{c}\text { Sample } \\
\text { ID }\end{array}$} & \multirow[b]{2}{*}{$\begin{array}{c}\text { Sample } \\
\text { date }\end{array}$} & \multicolumn{8}{|c|}{ Tritium-helium $\left({ }^{3} \mathrm{H} /{ }^{3} \mathrm{He}\right)$ data } \\
\hline & & $\begin{array}{c}{ }^{3} \mathbf{H} \\
\text { (TU) }\end{array}$ & $\begin{array}{c}{ }^{3} \mathrm{H} \\
\text { error } \\
1 \\
\text { sigma } \\
\text { (TU) }\end{array}$ & $\begin{array}{c}{\left[{ }^{4} \mathrm{He}\right]} \\
\text { measured } \\
\left(\mathrm{cm}^{3} \mathrm{STP} /\right. \\
\left.\mathrm{gH}_{2} \mathrm{O}\right)\end{array}$ & $\begin{array}{c}{\left[{ }^{3} \mathrm{He}\right]} \\
\text { measured } \\
\left(\mathrm{cm}^{3} \mathrm{STP} /\right. \\
\left.\mathrm{gH}_{2} \mathrm{O}\right)\end{array}$ & $\begin{array}{c}{ }^{3} \mathrm{H} /{ }^{3} \mathrm{He} \text { Age, } \\
\text { No } \\
\text { terrigenic } \\
\text { correction } \\
\text { (years) }\end{array}$ & $\begin{array}{c}\left.{ }^{3} \mathrm{He}\right] \\
\text { (TU) }\end{array}$ & $\begin{array}{c}{ }^{4} \mathrm{He}, \\
\text { terrigenic } \\
\text { percent }\end{array}$ & $\begin{array}{c}{ }^{3} \mathrm{H} /{ }^{3} \mathrm{He} \\
\text { age, adjusted } \\
\text { for terrigenic } \\
\text { He (years) }\end{array}$ \\
\hline PSW-1 & $12 / 30 / 03$ & 6.8 & 0.14 & $8.33 \mathrm{E}-8$ & $8.28 \mathrm{E}-14$ & NP & 2.99 & 34.3 & 6.6 \\
\hline PSW-1 & $08 / 11 / 04$ & 6.8 & 0.03 & $8.36 \mathrm{E}-8$ & $8.28 \mathrm{E}-14$ & NP & 2.46 & 33.5 & 5.5 \\
\hline WY69 & $12 / 10 / 03$ & 6.1 & 0.12 & $1.08 \mathrm{E}-7$ & $8.70 \mathrm{E}-14$ & NP & 2.34 & 45.8 & 5.8 \\
\hline WY70 & $12 / 29 / 03$ & 6.1 & 0.12 & $5.78 \mathrm{E}-8$ & $8.11 \mathrm{E}-14$ & 2.29 & 1.91 & 3.4 & 4.9 \\
\hline WY71 & $12 / 22 / 03$ & 7.0 & 0.14 & $5.36 \mathrm{E}-8$ & $7.34 \mathrm{E}-14$ & 0.03 & 0.75 & 2.5 & 1.8 \\
\hline WY72 & $12 / 16 / 03$ & 6.6 & 0.13 & $1.38 \mathrm{E}-7$ & $9.39 \mathrm{E}-14$ & NP & 3.96 & 56.3 & 8.4 \\
\hline WY73 & $12 / 17 / 03$ & 6.7 & 0.13 & $5.09 \mathrm{E}-8$ & $7.03 \mathrm{E}-14$ & 0.81 & 1.68 & 4.9 & 4.0 \\
\hline WY74 & $11 / 06 / 03$ & 7.1 & 0.14 & $5.27 \mathrm{E}-8$ & $7.31 \mathrm{E}-14$ & 0.82 & 0.30 & 0 & 0.75 \\
\hline WY75 & $11 / 13 / 03$ & 6.2 & 0.12 & $1.54 \mathrm{E}-7$ & $9.32 \mathrm{E}-14$ & $\mathrm{NP}$ & 4.63 & 62.2 & 10 \\
\hline WY76 & $11 / 12 / 03$ & 7.5 & 0.15 & $5.32 \mathrm{E}-8$ & $7.22 \mathrm{E}-14$ & -0.81 & 0.37 & 2.4 & 0.86 \\
\hline WY84 & $11 / 18 / 03$ & 7.0 & 0.14 & $6.18 \mathrm{E}-8$ & $8.72 \mathrm{E}-14$ & 2.30 & 1.47 & 1.5 & 3.4 \\
\hline WY85 & $11 / 19 / 03$ & 6.8 & 0.14 & $8.51 \mathrm{E}-8$ & $1.19 \mathrm{E}-13$ & 2.32 & 2.01 & 2.3 & 14.6 \\
\hline WY87 & $12 / 18 / 03$ & 7.0 & 0.14 & $5.86 \mathrm{E}-8$ & $8.86 \mathrm{E}-14$ & 6.96 & 5.18 & 5.8 & 9.9 \\
\hline WY100 & 08/03/04 & 6.5 & 0.13 & $7.05 \mathrm{E}-8$ & $8.18 \mathrm{E}-14$ & -49.90 & 2.04 & 21.0 & 4.9 \\
\hline WY101 & $08 / 04 / 04$ & 7.0 & 0.17 & 7.77E-8 & $8.16 \mathrm{E}-14$ & $\mathrm{NP}$ & 2.44 & 29.5 & 5.4 \\
\hline WY102 & $08 / 05 / 04$ & 6.0 & 0.31 & $6.28 \mathrm{E}-8$ & $7.13 \mathrm{E}-14$ & $\mathrm{NP}$ & 2.17 & 23.6 & 5.6 \\
\hline WY106 & $12 / 27 / 04$ & 0.10 & 0.004 & $2.19 \mathrm{E}-7$ & $6.17 \mathrm{E}-13$ & 128 & 219 & 76.6 & ${ }^{2}>50$ \\
\hline WY86 & $03 / 07 / 05$ & -- & & -- & -- & -- & -- & -- & -- \\
\hline WY97 & $02 / 16 / 05$ & -- & & -- & -- & -- & -- & -- & -- \\
\hline
\end{tabular}

${ }^{1}$ Gases likely fractionated due to gas stripping; age not reliable.

${ }^{2} \mathrm{Age}$ based on tritium concentration only.

${ }^{3}$ Highly contaminated with CFCs. 
Table 14. Summary of tritium/helium-3 $\left({ }^{3} \mathrm{H} /{ }^{3} \mathrm{He}\right)$, sulfur hexachloride $\left(\mathrm{SF}_{6}\right)$, and chlorofluorocarbons (CFC) groundwater age tracer data and apparent ages using a piston flow model for water samples in the study area, Woodbury, Connecticut, 2003-2005.—Continued

[Ages in bold are deemed most reliable; ID, identifier; NP, not possible to calculate an age; --, not measured; $\mathrm{cm}^{3} \mathrm{STP} / \mathrm{gH}_{2} \mathrm{O}$, cubic centimeters per gram of water at standard temperature and pressure; TU, tritium units; femtoMol/kg, femtomoles per kilogram; pmol/kg, picomoles per kilogram; pptv, parts per trillion by volume; bedrock wells shaded gray]

\begin{tabular}{|c|c|c|c|c|c|c|c|c|c|}
\hline \multicolumn{4}{|c|}{ Sulfur hexafluoride $\left(\mathrm{SF}_{6}\right)$ data } & \multicolumn{6}{|c|}{ Chlorofluorocarbons (CFC) data } \\
\hline $\begin{array}{c}\mathrm{SF}_{6} \\
\text { in } \\
\text { water } \\
\text { (femtoMol/ } \\
\text { kg) }\end{array}$ & $\begin{array}{l}\text { Calculated } \\
\text { SF }_{6} \\
\text { partial } \\
\text { pressure } \\
\text { (pptv) }\end{array}$ & $\begin{array}{c}\mathrm{SF}_{6} \text { apparent } \\
\text { recharge } \\
\text { year, } \\
\text { piston } \\
\text { flow }\end{array}$ & $\begin{array}{c}\mathrm{SF}_{6} \text { apparent } \\
\text { age, piston } \\
\text { flow }\end{array}$ & $\begin{array}{c}\text { CFC-11 } \\
\text { corrected } \\
\text { concentration } \\
(\text { pmol } / \mathrm{kg})\end{array}$ & $\begin{array}{c}\text { CFC-12 } \\
\text { corrected } \\
\text { concentration } \\
(\mathrm{pmol} / \mathrm{kg})\end{array}$ & $\begin{array}{c}\text { CFC-113 } \\
\text { corrected } \\
\text { concentration } \\
(p m o l / k g)\end{array}$ & $\begin{array}{l}\text { CFC-11 age } \\
\text { piston flow } \\
\text { (years) }\end{array}$ & $\begin{array}{l}\text { CFC-12 age } \\
\text { piston flow } \\
\text { (years) }\end{array}$ & $\begin{array}{c}\text { CFC-113 age } \\
\text { piston flow } \\
\text { (years) }\end{array}$ \\
\hline 2.72 & 5.51 & 2003.0 & Current & -- & -- & -- & -- & -- & -- \\
\hline 2.16 & 4.43 & 1999 & 5.7 & -- & -- & -- & -- & -- & -- \\
\hline 3.03 & 5.63 & 2003.5 & 0.9 & -- & -- & -- & -- & -- & -- \\
\hline 3.09 & 6.14 & Current & Current & -- & -- & -- & -- & -- & -- \\
\hline 4.05 & 8.04 & Current & Current & -- & -- & -- & -- & -- & -- \\
\hline 3.12 & 6.22 & Current & Current & -- & -- & -- & -- & -- & -- \\
\hline 2.73 & 6.97 & Current & Current & -- & -- & -- & -- & -- & -- \\
\hline 2.89 & 6.89 & Current & Current & -- & -- & -- & -- & -- & -- \\
\hline 2.82 & 5.32 & 2002.5 & 1.4 & -- & -- & -- & -- & -- & -- \\
\hline 2.66 & 6.30 & Current & Current & -- & -- & -- & -- & -- & -- \\
\hline 3.23 & 4.53 & 1999.3 & 4.6 & -- & -- & -- & -- & -- & -- \\
\hline 1.48 & 2.95 & 1992.8 & ${ }^{1} 11$ & -- & -- & -- & -- & -- & -- \\
\hline 3.35 & 6.67 & Current & Current & -- & -- & -- & -- & -- & -- \\
\hline 2.13 & 4.16 & 1998 & 6.7 & -- & -- & -- & -- & -- & -- \\
\hline 2.62 & 5.46 & 2000.5 & 4.2 & -- & -- & -- & -- & -- & -- \\
\hline 2.63 & 5.64 & 2002.5 & 2.2 & -- & -- & -- & -- & -- & -- \\
\hline-- & -- & -- & -- & -- & -- & -- & -- & -- & -- \\
\hline 19.4 & 31.7 & $\mathrm{NP}$ & $\mathrm{NP}$ & 2.01 & 3.35 & 0.148 & 33 & 9.5 & 27 \\
\hline-- & -- & -- & -- & 36.7 & 2.72 & 0.389 & ${ }^{3} \mathbf{N P}$ & 22 & 20 \\
\hline
\end{tabular}


and adjacent monitoring-well screens, WY100 and WY101. Samples from each of these wells likely consist of a composite of waters with a wide range of ages, including about 4 percent of water that was older than 10 years.

Concentrations of selected chemical constituents and redox conditions also were related to groundwater age. The concentration of dissolved solids generally increases with the length of time groundwater remains in contact with source material. Concentrations of constituents such as $\mathrm{SiO}_{2}$ and $\mathrm{HCO}_{3}^{-}$may be a function of residence time, but they also can be affected by the aquifer material. High $\mathrm{SO}_{4}{ }^{2-}$ concentrations, for example, were associated with groundwater from fractured basalt beneath the valley bottom (fig. 25B). Silica saturation with respect to quartz generally was higher in the wells screened in till and bedrock than those in the glacial stratified deposits. The weathering of silicates in glacial stratified deposits should be fairly uniform, and the $\mathrm{SiO}_{2}$ content generally should be reflective of groundwater age, temperature, and $\mathrm{pH}$, except in parts of the aquifer system near bedrock and till that contain greater amounts of calcite and silicates other than quartz. Silica saturation showed a linear relationship with apparent groundwater age with the exception of water samples from bedrock wells WY97 and WY106 that were affected chemically by interactions with till and deep Mesozoic basin water, respectively (fig. 31A). The calcite saturation index generally was lower in shallow glacial wells compared to wells screened in deep glacial stratified deposits and till (fig. 31B) and probably reflects a lower calcite content; water samples from bedrock wells all had a calcite saturation index near saturation.

\section{Water Sources and Pathways}

Results for all useful tracers of major water sources discussed previously are integrated in this section to characterize the source, transport, and receptor processes that affect the movement of selected natural and anthropogenic constituents to PSW-1. Characterization of water in different parts of the aquifer system is based on concentrations of selected inorganic constituents, $\mathrm{pH}$, ion ratios, stable isotope ratios, recharge temperature, and selected anthropogenic and natural contaminants. The major sources of water and the indicative chemical characteristics used to identify the sources are described in table 15.

Water from wells completed in fractured bedrock and till generally contained high $\mathrm{pH}$ and high concentrations of $\mathrm{HCO}_{3}^{-}$, $\mathrm{U}$, and ${ }^{222} \mathrm{Rn}$, and calcite was near saturation relative to that in other wells. A water sample from the deep bedrock well, WY106, and several deep glacial aquifer wells had depleted $\delta^{18} \mathrm{O}$ and $\delta \mathrm{D}$ values and high concentrations of $\mathrm{SO}_{4}{ }^{2-}$ with enriched $\delta^{34} \mathrm{~S}$ relative to those from other wells (fig. $25 \mathrm{~A}$ and B). As discussed previously in the "Stable Isotopes" section, $\mathrm{SO}_{4}^{2-}$ concentrations and their $\delta^{34} \mathrm{~S}$ values in samples from several deep glacial wells and a shallow glacial well, WY81, plot along a hyperbola-shaped mixing line between
WY100 and WY106; the samples appear to contain a fraction of heavy S from underlying bedrock, as represented by WY106 (fig. 25B). Monitoring wells WY88, WY102, WY100, WY101, WY82, WY81, WY72, WY75, and WY69, and PSW-1 contained water that is mostly representative of the glacial aquifer, but results of inverse geochemical modeling with PHREEQC indicated that the water also contained amounts of an end member, represented by water from WY106, ranging from 0 to 6.2 percent (table 16). Although WY102 is a shallow well, upward flow from bedrock below could affect chemistry in the well. Furthermore, the location of values of $\mathrm{SO}_{4}{ }^{2-}$ and $\delta^{34} \mathrm{~S}_{\text {of }} \mathrm{SO}_{4}{ }^{2-}$ for WY102 near the binary mixing model line (fig. 28C) also indicates a contribution of flow from underlying bedrock. The geochemical models included pyrite and gypsum as mineral phases; some models could be run without using $\delta^{34} \mathrm{~S}$ as a constraint, but those models required precipitation of pyrite or dissolution of gypsum (table 16). Samples from several wells that are near septic-tank drainfields and appear to have been affected by septic-system leachate fall within a range of relatively depleted $\delta^{34} \mathrm{~S}$ of $\mathrm{SO}_{4}{ }^{2-}$ isotope values from 4.3 to 6.3 per mil (fig. 25B).

As discussed previously, several groundwater samples in the study area appear to have been affected by water from Mesozoic basin rocks or associated minerals and sorbed complexes. Although most brine water generated during basalt emplacement is likely to be purged from the fractured bedrock aquifer, Shapiro (2002) concludes that high concentrations of constituents could persist for long periods of time in small bedrock fractures that transmit water very slowly. Furthermore, sorption modeling by Appelo and Postma (1993) shows that sorbed constituents can persist for long periods of time. Although water from Mesozoic basin rocks may contain associated constituents of concern, the older age shows that the water predates substantial development, and therefore, the water had a lower vulnerability to anthropogenic contamination (table 16).

Groundwater with locally reducing conditions and high concentrations of As was observed in samples from wells screened in glacial deposits that contain entrained Mesozoic sediments, particularly WY83, and to a lesser extent WY35, WY88, and WY53. Concentrations of As, Co, and $\mathrm{Li}$ were relatively high in groundwater samples from WY83. Concentrations of $\mathrm{As}, \mathrm{U}, \mathrm{Cd}$, and $\mathrm{Pb}$ were high in the 10 percent $\mathrm{HNO}_{1}^{-}$extractions of sediment samples that were collected at the depth interval of the screen at WY83. U concentrations were low in groundwater samples from WY 83 because $\mathrm{U}$ typically is chemically reduced and immobile in reduced, organic-rich horizons. Water samples from wells WY35, WY88, and WY53 had high concentrations of Fe and (or) $\mathrm{Mn}$ and detectable concentrations of As, and some other trace elements that indicate that Mesozoic source rocks may have affected groundwater chemistry at these sites. Samples from other glacial wells adjacent to or overlying Mesozoic rocks in the Hartford Basin, such as S401 and F344, were found to have high concentrations of trace constituents, 

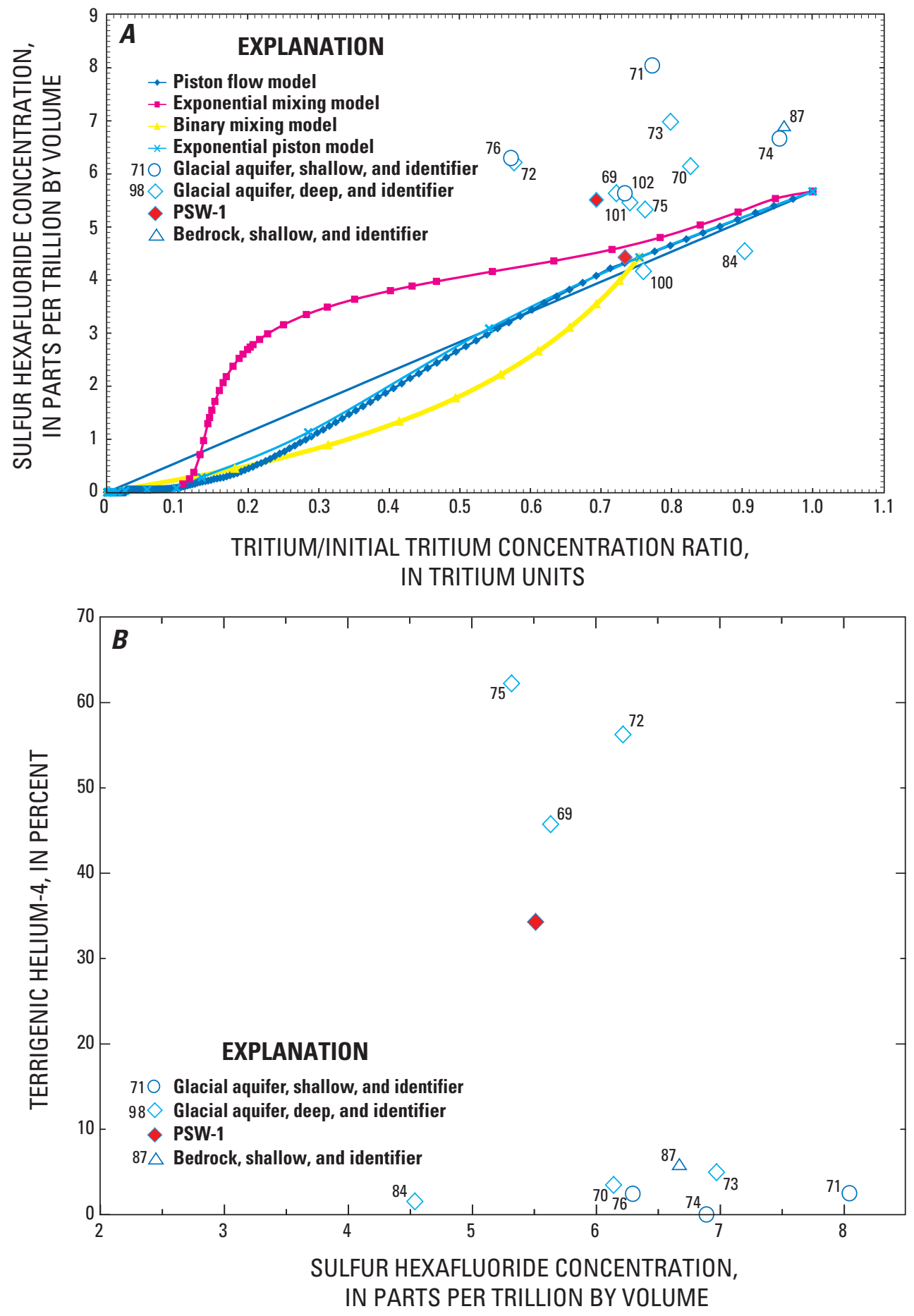

Figure 29. (A) Tritium/initial tritium $\left({ }^{3} \mathrm{H} /{ }^{3} \mathrm{H}_{(0)}\right)$ concentrations as a function of sulfur hexafluoride $\left(\mathrm{SF}_{6}\right)$ concentrations, with modeled curves for various groundwater age distributions, and $(B)$ sulfur hexafluoride $\left(\mathrm{SF}_{6}\right)$ concentrations as a function of terrigenic helium-4 $\left({ }^{4} \mathrm{He}\right)$ concentrations, in groundwater samples from wells in the study area, Woodbury, Connecticut. 


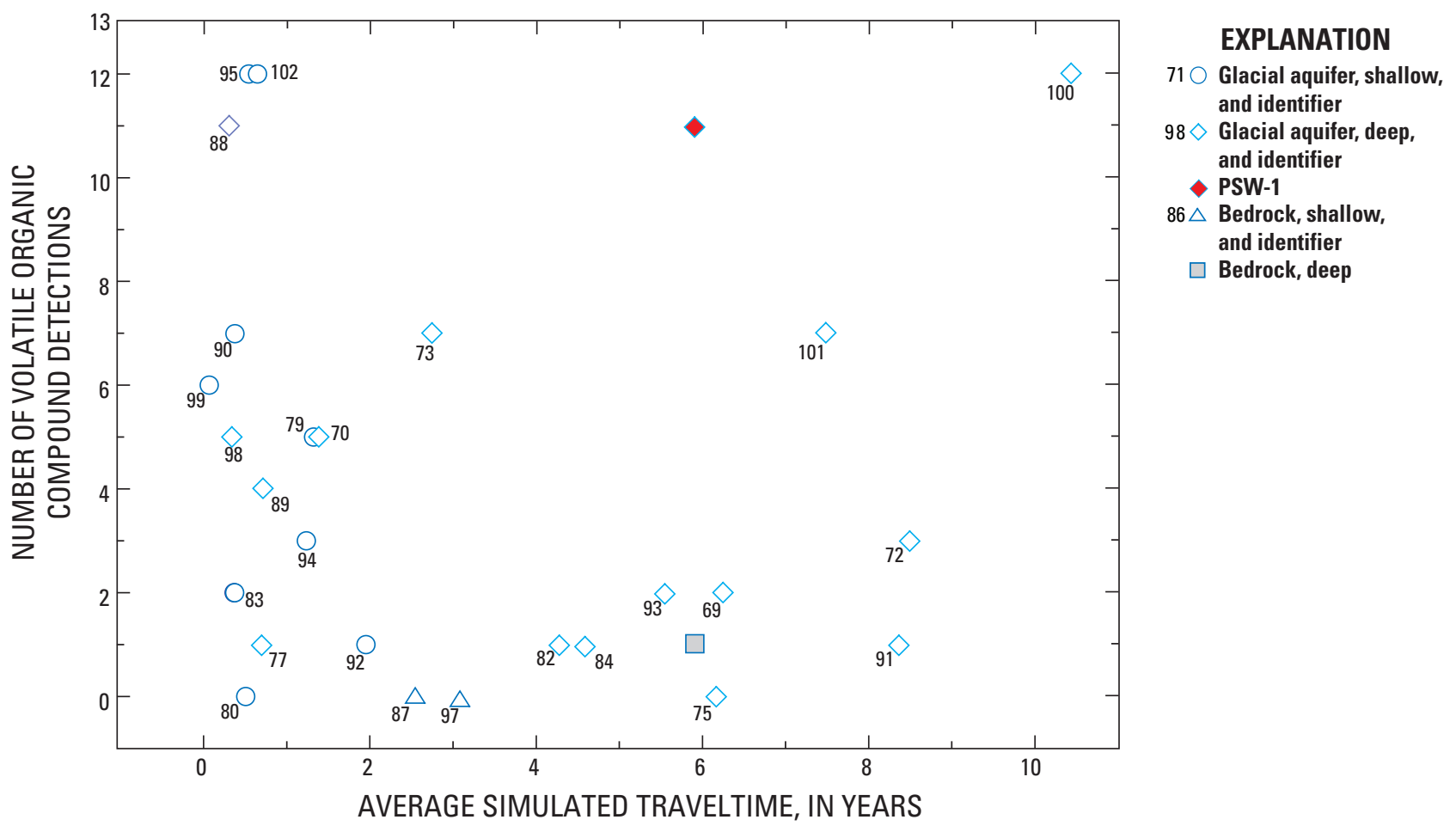

Figure 30. Average simulated mean traveltimes of groundwater to wells based on particles in MODPATH (Starn and Brown, 2007) as a function of the number of volatile organic compounds (VOCs) detected in groundwater samples from wells in the study area, Woodbury, Connecticut.

including As, Ba, B, Li, Sr, and V (table 8). As discussed previously, groundwater at these sites could be affected by glacial sediments derived from similar underlying Mesozoic rocks and (or) deep, ancient basin water, and thus the wells at these sites are more vulnerable to natural contaminants. Domestic or public-supply wells in such areas could be subject to high concentrations of $\mathrm{As}$ if $\mathrm{Fe}$ - or $\mathrm{Mn}$-reducing conditions prevail or $\mathrm{U}$ if oxic conditions prevail.

Most detections of VOCs were in samples of relatively young groundwater from shallow or intermediate depths of the glacial aquifer (fig. 30) and were related to commercial and light-industrial development (WY71, WY76, and WY95, although some detections appeared to be related to residential land use (WY94, WY89, WY90, and WY96).

\section{Factors Affecting the Water Chemistry at the Public-Supply Well}

Pumping of PSW-1 changes the distribution of groundwater flow paths and the rate of flow to PSW-1. PSW-1 has a relatively low pumping rate $\left(4.53 \times 10^{-3} \mathrm{~m}^{3} / \mathrm{s}\right.$, or $71.9 \mathrm{gal} / \mathrm{min}$ ) compared to some other wells in glacial aquifers (Warner and Arnold, 2006) but can still capture contaminants and speed up their movement in the zone of contribution. The water withdrawn from PSW-1 is derived from different landuse settings, but a major part of groundwater is young and derived from recharge in residential and commercial land-use areas (fig. 4). On the basis of simulations with MODPATH (Starn and Brown, 2007), about 16 percent of the water from PSW-1 originates in the zone of higher recharge rates in the commercial area; the residence time for PSW-1 water recharged in the commercial area ranges from 1.6 to 3.8 years, and median flow-weighted residence time is 2.5 years (Starn and Brown, 2007). Water derived from the parking-lot drains (dry wells) and septic-tank drainfields in the commercial area results in only a slightly higher percentage of younger water to the PSW-1, but a spill in that area would cause a much more rapid effect at PSW-1 because of the drains.

The groundwater pathways to the PSW-1 screen are affected by the lithology of intervening glacial deposits. Samples from the monitoring well cluster installed adjacent to PSW-1 were collected to understand vertical differences in water chemistry near PSW-1. This cluster of wells includes three wells with 0.6 - to $1.0-\mathrm{m}$ long screens: one is completed near the water table about $4 \mathrm{~m}$ below land surface, one is completed just above the top of the PSW-1 screen, and one is completed near the center of the PSW-1 screen. Geophysical logging and water-quality profiling also were conducted for a borehole that was located adjacent to, and spanned the length of, the PSW-1 screened interval. Profiles of temperature, specific conductance, DO, and flows with an electromagnetic (EM) flowmeter were conducted under pumping and nonpumping conditions. 

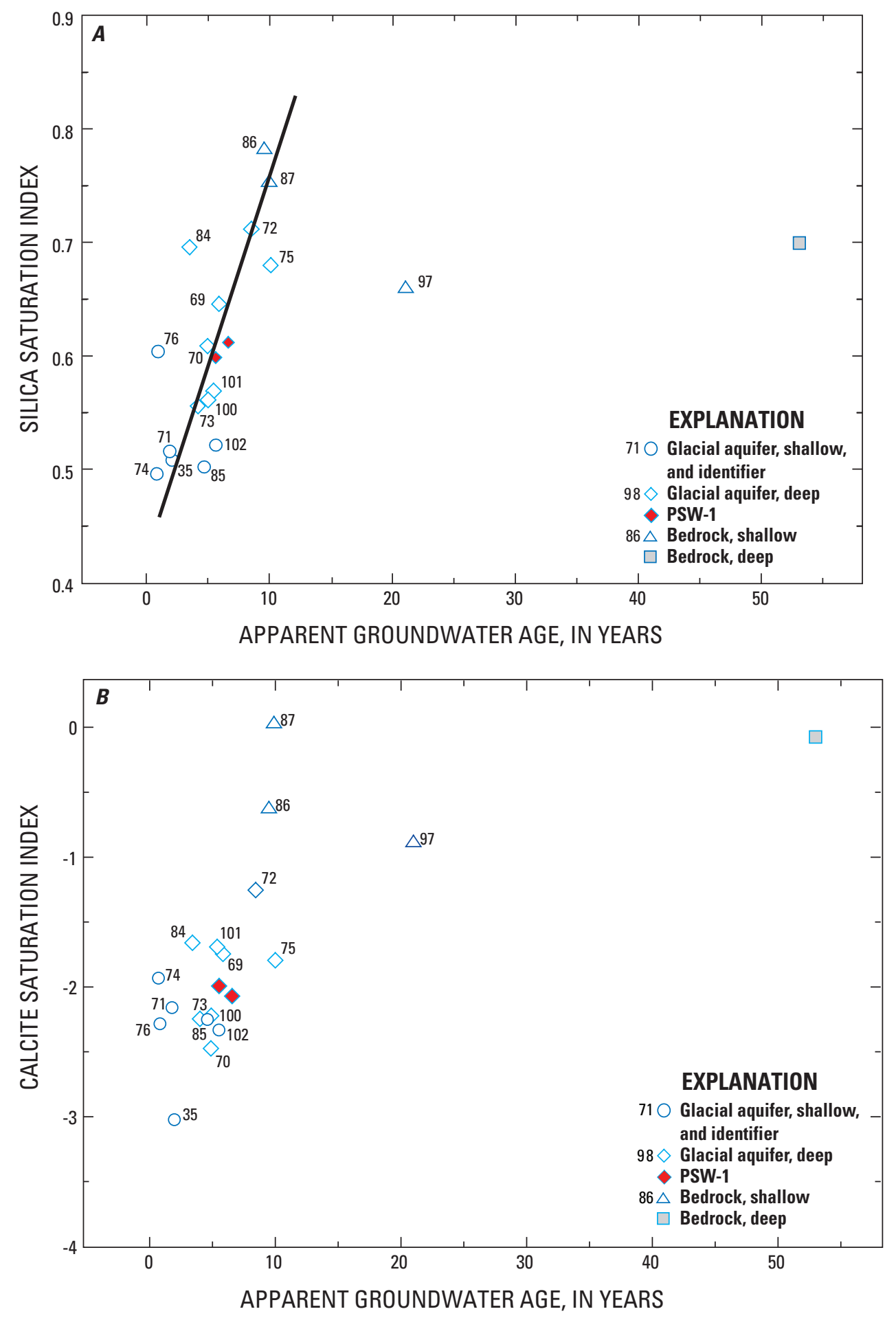

Figure 31. Apparent groundwater age as a function of the $(A)$ silica saturation index and $(B)$ calcite saturation index, in groundwater samples from wells in the study area, Woodbury, Connecticut. 
Table 15. Summary of major geochemical sources and the indicative chemical characteristics in the aquifer system of the study area, Woodbury, Connecticut.

$\left[\mathrm{SO}_{4}{ }^{2-}\right.$, sulfate; $\mathrm{HCO}_{3}{ }^{-}$, bicarbonate, $\mathrm{U}$, uranium; ${ }^{222} \mathrm{Rn}$, radon-222; As, arsenic; $\delta^{34} \mathrm{~S}$, delta sulfur-34; $\delta^{13} \mathrm{C}$, delta carbon- $13 ; \delta^{18} \mathrm{O}$, delta oxygen-18; $\delta \mathrm{D}$, delta deuterium; DOC, dissolved organic carbon; Fe, iron; Mn, manganese; DO, dissolved oxygen; $\mathrm{Na}^{+}$, sodium; $\mathrm{Cl}^{-}$, chloride; $\mathrm{Br}^{-}$, bromide; $\mathrm{Ca}^{2+}$, calcium; $\mathrm{B}$, boron; $\delta^{15} \mathrm{~N}$, delta nitrogen-15; $\mathrm{NO}_{3}^{-}$, nitrate; PCE, perchloroethene; TCE, trichloroethylene; 1,1-DCE, 1,1-dichloroethylene]

\begin{tabular}{|c|c|}
\hline Major sources & Indicative chemical characteristics \\
\hline 1. Bedrock and till effects on the glacial aquifer & $\begin{array}{l}\text { High } \mathrm{pH} \text { and concentrations of } \mathrm{SO}_{4}^{2-}, \mathrm{HCO}_{3}^{-}, \mathrm{U},{ }^{222} \mathrm{Rn} \text {, and } \mathrm{As} \\
\text { relative to other wells; reducing redox conditions; enriched } \delta^{34} \mathrm{~S} \\
\text { of } \mathrm{SO}_{4}^{2-} \text { and } \delta^{13} \mathrm{C} \text { ratios; depleted } \delta^{18} \mathrm{O} \text { and } \delta \mathrm{D} \text { ratios; calcite near } \\
\text { saturation; low recharge temperatures; and older (greater than } \\
6 \text { years) groundwater ages relative to shallow and intermediate } \\
\text { wells in glacial stratified deposits. }\end{array}$ \\
\hline 3. Road salt (halite) & High $\mathrm{Na}^{+}, \mathrm{Cl}^{-}, \mathrm{Ca}^{2+}$; high $\mathrm{Cl} / \mathrm{Br}$ ratios. \\
\hline 4. Septic-system leachate & $\begin{array}{l}\text { High } \mathrm{NO}_{3}^{-}, \text {DOC, } \mathrm{Na}^{+}, \mathrm{Cl}^{-}, \mathrm{Ca}^{2+} \text {, and } \mathrm{B} \text {; enriched } \delta^{15} \mathrm{~N}^{2} \text { and } \delta^{18} \mathrm{O} \text { of } \\
\mathrm{NO}_{3} \text {; indicative } \mathrm{Cl} / \mathrm{Br} \text { ratios. }\end{array}$ \\
\hline 7. Surface-water leakage & Enriched $\delta^{18} \mathrm{O}$ and $\delta \mathrm{D}$; seasonally high DOC and low $\mathrm{DO}$ or $\mathrm{NO}_{3}^{-}$. \\
\hline
\end{tabular}

As described in the "Hydrology" section, the glacial aquifer deposits adjacent to PSW-1 were found to have two zones of preferential flow-one adjacent to the bottom and one just above the top of the PSW-1 screen; the aquifer adjacent to the center of the screen is generally composed of finer deposits and appears to be less conductive to flow. Measurements made with a water-quality monitor in the borehole showed an increase in temperature and specific conductance and a decrease in DO concentrations in a narrow interval coincident with the lowermost zone of high permeability identified with the borehole flowmeter. This interval is located near the bottom of the PSW-1 screen, and the data indicate that the stratified nature of the deposits results in zones that are substantially more permeable than adjacent zones and that are likely to be the primary pathways for groundwater flow. These zones of preferential flow can be very thin (less than $0.1 \mathrm{~m}$ ) and may not be adequately assessed with monitoring wells alone.

Water-quality data from monitoring wells and boreholes near PSW-1 also indicate that the chemistry of water in the aquifer varies over short vertical intervals near PSW-1. These vertical variations in aquifer chemistry are affected by heterogeneities in the aquifer deposits and the presence of upgradient point sources of contaminants. Constituents in samples collected from the well clusters located throughout the zone of contribution to PSW-1 were consistent with those constituents in samples collected near PSW-1, indicating that the water quality in this study area primarily was affected by the distribution of point sources, such as septic-tank drainfields and solvent or gasoline station leaks or spills (Brown and others, 2006), and by aquifer characteristics. VOC concentrations in samples collected from PSW-1 generally were within the range of high concentrations in samples from monitoring wells screened near the top of PSW-1 and low concentrations in samples from the well screened near the center of the PSW-1 screened interval (13.7 to $18.3 \mathrm{~m}$ depth).

$\mathrm{NO}_{3}{ }^{-}$concentrations and $\delta^{15} \mathrm{~N}$ and $\delta^{18} \mathrm{O}$ of $\mathrm{NO}_{3}{ }^{-}$were used to model sources of $\mathrm{N}$ for PSW-1. $\mathrm{NO}_{3}^{-}$concentrations in recharge from forested land-use areas in Connecticut and other northeastern states typically are less than $1 \mathrm{mg} / \mathrm{L}$ as $\mathrm{N}$, so soil $\mathrm{N}$ is not a likely source of the large $\mathrm{NO}_{3}^{-}$as $\mathrm{N}$ concentrations in recharge. Samples from PSW-1 plot along a mixing line with end points at forested land use, represented by WY87, and urban land use downgradient from a septic-tank drainfield, WY90 (fig. 26B); 10 to 15 percent of the $\mathrm{NO}_{3}^{-}$as $\mathrm{N}$ in those samples may have been contributed by a septic-tank drainfield (McMahon and others, 2008). 

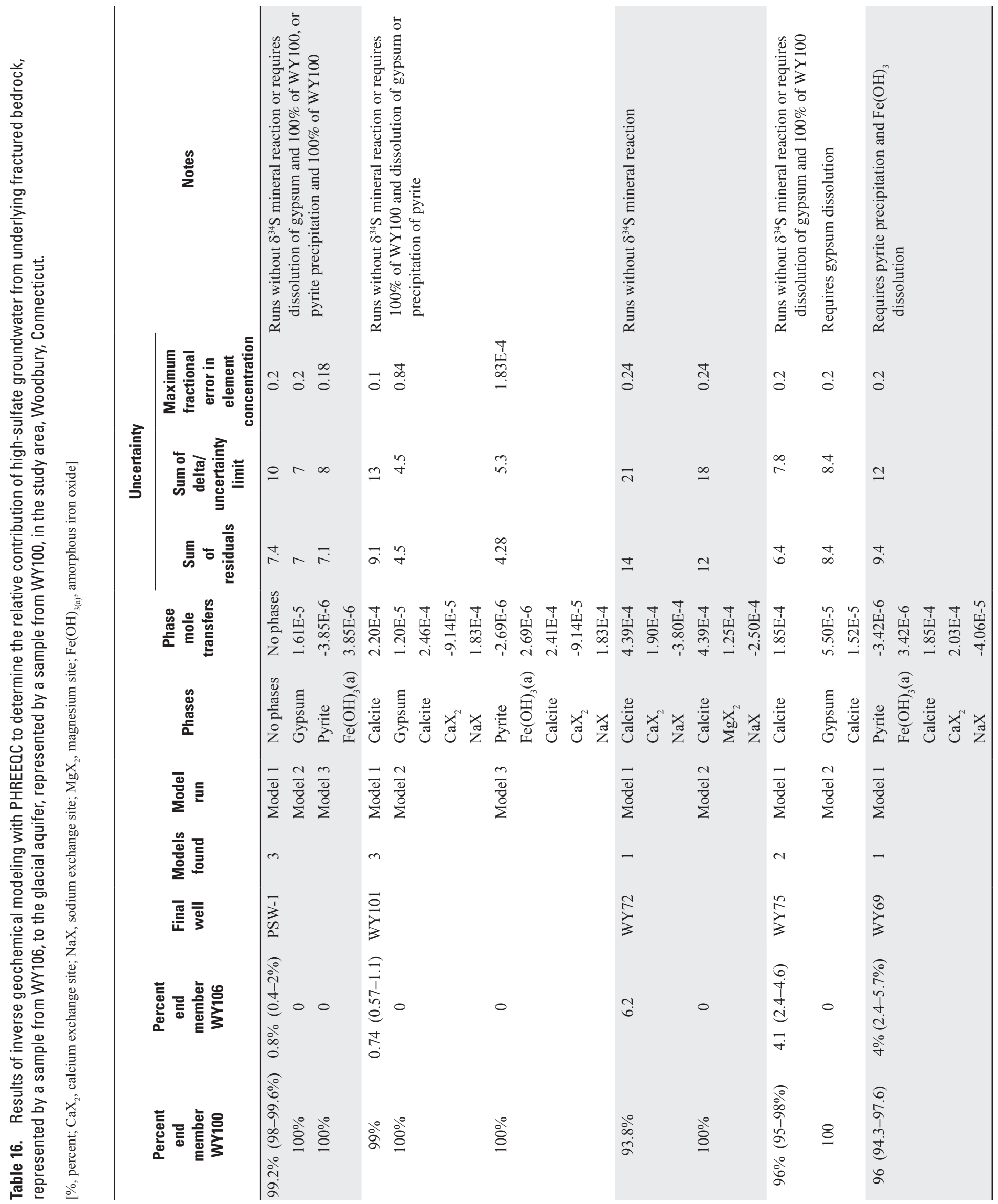
Inverse geochemical modeling with PHREEQC was done to help determine the contribution of water from different depths to PSW-1. Mixing of water represented by samples with complete major-ion data for wells adjacent to PSW-1 was simulated without mass transfer. Two hypothetical models were generated (table 17). Results from the first model indicate that 99.2 percent of the contribution of groundwater to PSW-1 is composed of water represented by adjacent monitoring well WY100 (near the top of the PSW-1 screen) and that about 1 percent is composed of water from underlying fractured bedrock, as represented by WY106 (table 17). Results from the second model indicate, again, that most of the water (98.5 percent) is derived from flow near the top of the screen represented by WY100, but the other 1.5 percent is derived from flow at the middle of the screen represented by WY101. Both of these models indicate that groundwater chemistry is not uniform throughout the vertical extent of the aquifer, but is affected by the most permeable pathways. Furthermore, there may be no contribution from the shallow part of the aquifer represented by WY102 (table 17). The result from either model is feasible, but the two hypothetical mixing cases proposed may not be the only options, and water pumped at PSW-1 could be derived from depths and pathways other than those represented by samples from adjacent monitoring well screens. For example, the $\delta^{18} \mathrm{O}$ and $\delta \mathrm{D}$ values for a water sample collected from PSW-1 plot near the evaporation line (fig. 25A) and indicate that the Pomperaug River may contribute water to well PSW-1.

The contribution of water from fractured bedrock to deep wells in the glacial aquifer, based on geochemical modeling of $\delta^{34} \mathrm{~S}_{\text {of }} \mathrm{SO}_{4}^{2-}$ (table 16), is consistent with results of the groundwater-flow budget in the flow model (Starn and Brown, 2007). Predevelopment groundwater flowing upward from bedrock is likely to have low or undetectable concentrations of anthropogenic contaminants and, given the low concentrations of naturally occurring contaminants in samples from PSW-1, lowers the vulnerability of PSW-1 to contamination.

\section{Summary and Conclusions}

A study was conducted to investigate the vulnerability of a public-supply well to anthropogenic and naturally occurring contaminants in a glacial aquifer system in Woodbury, Connecticut, as part of the U.S. Geological Survey National Water Quality Assessment (NAWQA) Program. The publicsupply well, PSW-1, is screened in the glacial aquifer and supplies a large portion of the locally used water. Wells in the glacial aquifer system are vulnerable to contamination from a variety of sources because of the short groundwater residence times and the urban land use in the contributing recharge area to PSW-1. Study of the vulnerability included an assessment of the chemical constituents in the unconsolidated glacial and surficial deposits, as well as the underlying and adjacent fractured bedrock, because these deposits and rocks can be sources of naturally occurring contaminants to PSW-1 as a result of aquifer weathering and other processes.

Water samples were collected during 2002-06 from the public-supply well and from 35 monitoring wells, which include 25 that are screened in glacial stratified deposits, 6 that are screened in glacial till, and 4 in fractured bedrock. The chemistry of groundwater in the glacial deposits is affected by anthropogenic sources, including road salt, septic-tank drainfields, leaking underground storage tanks or chemical spills, stormwater runoff from roads and parking lots to dry wells or losing streams, and weathering of aquifer material and associated naturally occurring contaminants.

Abundances of organic matter can cause locally reducing conditions in this generally oxic aquifer system but are spatially limited in these glacial aquifers. Organic carbon (C) sources consisting of (1) natural organic matter in surface water in the summer and fall months; (2) natural sedimentary organic matter, in greater abundance in some sediments; and (3) point sources of contaminants, including septic-tank drainfields and leaking underground storage tanks can result in local reducing zones that affect the movement of many contaminants. Denitrification takes place downgradient from septic-tank drainfields in at least one location. Localized reducing zones also can affect the mobilization of trace elements, including arsenic (As) and uranium (U), and affect the degradation of volatile organic compounds (VOCs).

Bedrock composed of Paleozoic metamorphic rocks underlies the uplands in the eastern part of the study area, and Mesozoic basalt and sedimentary rocks directly underlie the valley. The Mesozoic-rock sequence is at least 300 meters thick and includes as many as three basalt layers interbedded with shale, arkosic sandstone, and conglomerate that dip eastward. Concentrations of arsenic (As) and uranium (U) in aquifer sediment or rock sample extractions generally were low and corresponded to low concentrations in groundwater. Glacial deposits that appear to be derived from the Mesozoic Cass Formation, however, contain locally abundant concentrations of organic $\mathrm{C}$ and extractable As, $\mathrm{U}$, and other trace elements that can be mobilized in groundwater.

Concentrations of As and $\mathrm{U}$ in groundwater generally were low in the study area, which is typical of glacial aquifers in much of the eastern United States. Concentrations of As in groundwater samples ranged from less than the minimum reporting level (MRL) of 0.2 micrograms per liter $(\mu \mathrm{g} / \mathrm{L})$ to $5.8 \mu \mathrm{g} / \mathrm{L}$. In samples from most wells, including PSW-1, concentrations of As were less than the MRL. The mobility of As appeared to be greater under relatively reducing conditions; samples that contained the highest dissolved As concentrations had low (less than 2 milligrams per liter or $\mathrm{mg} / \mathrm{L}$ ) dissolved oxygen (DO) concentrations, and (or) high dissolved iron (Fe) or manganese (Mn) concentrations (greater than $100 \mu \mathrm{g} / \mathrm{L}$ and greater than $50 \mu \mathrm{g} / \mathrm{L}$, respectively). Some of the highest As concentrations in groundwater samples were contributed by aquifer sediments that appear to be derived from the organicrich units of the Cass Formation, probably through desorption of $\mathrm{As}(\mathrm{V})$ or reductive dissolution of ferric oxyhydroxides 
Table 17. Results of inverse geochemical modeling with PHREEOC using delta sulfur-34 to determine the relative contribution of groundwater to PSW-1 from various depths represented by adjacent monitoring wells WY102, 100, 101, and 106, in the study area, Woodbury, Connecticut.

[ID, identifier. Values in parentheses are ranges that account for uncertainty in analytical data.]

\begin{tabular}{lll}
\hline \multicolumn{1}{c}{ Well ID } & Model 1 & \multicolumn{1}{c}{ Model 2 } \\
\hline WY102 & 0 percent & 0 percent \\
WY100 & 99.2 percent & 98.5 percent \\
& $(98.4-99.9$ percent $)$ & $(98.4-98.5$ percent $)$ \\
WY101 & 0 percent & $(1.5$ percent \\
& & 0 percent \\
WY106 & 0.8 percent & \\
Sum of residuals & $(0.1-1.6$ percent $)$ & 15 \\
Sum of delta/uncertainty limit & 11 & 23 \\
Maximum fractional error in element concentration & 16 & 0.15 \\
\hline
\end{tabular}

coupled with the oxidation of organic $\mathrm{C}$ and the subsequent mobilization of As. Water samples from several glacial-aquifer wells to the north and west of PSW-1 also were geochemically similar to the Cass Formation, and their locations are consistent with the southward, down-valley direction by which glacial deposits would have been transported by glacial ice.

Dissolved U concentrations in groundwater samples ranged from less than the MRL $(0.2 \mu \mathrm{g} / \mathrm{L})$ to $1.8 \mu \mathrm{g} / \mathrm{L}$, and concentrations in samples from PSW- 1 were about $0.06 \mu \mathrm{g} / \mathrm{L}$. $\mathrm{U}$ in water generally was highest in wells in crystalline (Paleozoic-age) bedrock, glacial till, and in the deep glacial stratified deposits. Factors such as the proximity of the well screen to bedrock and the associated higher bicarbonate $\left(\mathrm{HCO}_{3}^{-}\right)$concentrations and predominance of uranyl-carbonate complexes had a greater effect on $U$ mobility in the aquifer than did redox chemistry. $U$ concentrations in groundwater samples from a monitoring well (WY83) were low despite the high concentrations in extractions from sediments sampled adjacent to the screen because $U$ typically is reduced and immobilized in organic-rich zones or layers.

Radon-222 (222 Rn) activities in groundwater samples from the Woodbury study area ranged from 490 to 13,000 picocuries per liter $(\mathrm{pCi} / \mathrm{L})$, and all exceeded the proposed maximum contaminant level (MCL) of $300 \mathrm{pCi} / \mathrm{L}$. The ${ }^{222} \mathrm{Rn}$ activities in water samples from the bedrock wells generally were higher than other wells. The two wells in upland Paleozoic fractured bedrock had ${ }^{222} \mathrm{Rn}$ activities of 8,600 and $13,000 \mathrm{pCi} / \mathrm{L}$, whereas wells in fractured basalt had lower ${ }^{222} \mathrm{Rn}$ activities of 1,600 and $5,500 \mathrm{pCi} / \mathrm{L}$. The median activity in wells screened in the glacial aquifer of the study area was $1,100 \mathrm{pCi} / \mathrm{L}$, greater than the median of $440 \mathrm{pCi} / \mathrm{L}$ for shallow wells in other glacial aquifers of the northeastern United States. The high ${ }^{222} \mathrm{Rn}$ concentrations in the glacial aquifer may indicate an abundant but relatively immobile mass of $U$ and radium-226 on aquifer sediment surfaces but not dissolved in groundwater.
Experimental data for adsorption batch reactor experiments were modeled using PHREEQC with a generalized two-layer surface complexation model to determine adsorption reactions. Significant adsorption of both As and U was observed in the four glacial stratified sand and gravel samples, and much less sorption by the sample of glacial till. There was a net release of U(VI) to solution in the experiment with aquifer material from WY90, and it is possible that there was some U(VI) coprecipitated with the carbonate minerals in the sediment that was released. The net release of U(VI) from glacial till sediments experiments is consistent with higher concentrations of $U$ in water samples from wells screened in deep glacial deposits and in bedrock than in those screened in shallow, carbonate-poor glacial deposits.

VOCs were widely detected in water samples from monitoring wells throughout the glacial aquifer and from PSW-1. VOCs were detected in samples from 89 percent of wells. Most VOCs were detected in water samples from shallow or intermediate depths of the glacial aquifer and were related to commercial- and light-industrial landuse areas. Eleven VOCs were detected in water from PSW-1: perchloroethene (PCE), 1,1,1-trichloroethane (TCA), trichloroethene (TCE), 1,1-dichloroethane (DCA), cis-1,2-dichloroethene (cis-1,2-DCE),1-dichloroethene (1,1-DCE), methyl-tert-butyl ether (MTBE), tert-amyl methyl ether (TAME), ethyl-tert-butyl ether (ETBE), 1,1,2-trichlorotrifluoroethane (CFC-113), and chloroform. Several point sources are present in the commercial area upgradient from PSW-1, including two or more chlorinated solvent spills evidenced since 1978, and an MTBE plume discovered in 2003 that had leaked from a gasoline station. MTBE was the most frequently detected compound, found in 50 percent of wells sampled. The compounds benzene, toluene, ethylbenzene, xylene also were detected but at lower concentrations and much less frequently. Chloroform was the 
second most frequently detected VOC, found in 47 percent of wells sampled, but concentrations in samples from all but two of the wells were estimated at less than the MRL. The presence of chloroform was attributed to the use of chlorinated drinking water and the associated recharge from septic-tank drainfields or lawn irrigation, or well disinfection. Chlorinated solvents were the third most frequently detected group of VOCs in this study and likely were used for degreasing, dry cleaning, and electronics manufacturing, and as ingredients in septic-tank cleaning products in upgradient residential, commercial, and light-industrial areas. Of the 30 VOCs detected in groundwater samples, two compounds exceeded drinking-water standards (PCE and TCE). PCE was detected in 42 percent of wells sampled, and concentrations were highest in samples from several monitoring wells downgradient from the commercial area. PCE in one well exceeded the U.S. Environmental Protection Agency (USEPA) MCL of $5 \mu \mathrm{g} / \mathrm{L}$ at concentrations up to $11 \mu \mathrm{g} / \mathrm{L}$. TCE was detected in samples from 33 percent of wells, with four of these detections exceeding the USEPA MCL of $5 \mu \mathrm{g} / \mathrm{L}$ at concentrations up to $25 \mu \mathrm{g} / \mathrm{L}$. Concentrations of TCE exceeded the MCL in four of the six groundwater samples collected from PSW-1 before treatment and ranged from 4.3 to $16 \mu \mathrm{g} / \mathrm{L}$.

Pesticides were detected at relatively low concentrations in only a few wells in the study area. Atrazine was rarely detected, probably because there is little agricultural land use in the study area. Prometon and simazine, which are more soluble and mobile in water and more widely used in areas of mixed land use and urban land use, were detected at low concentrations in shallow and deep glacial wells downgradient from the commercial area. The insecticide fipronil was detected only at estimated concentrations less than the MRL in PSW-1 and an adjacent monitoring well. The presence of some compounds including fipronil and paradichlorobenzene (p-DCB) in samples from wells downgradient from the commercial area indicates a possible association with the upgradient commercial and industrial land-use area, and with associated septic-system leachate.

Tritium-helium $\left({ }^{3} \mathrm{H}-{ }^{3} \mathrm{He}\right)$ age tracers were used to estimate apparent groundwater ages in most wells in the glacial aquifer. Chlorofluorocarbons (CFCs) were used to date samples from two bedrock wells where excess helium-4 $\left({ }^{4} \mathrm{He}\right)$ precluded a ${ }^{3} \mathrm{H}-{ }^{3} \mathrm{He}$ date. Apparent groundwater ages are less than 9 years for water samples from glacial aquifer deposits but greater than 9 years in samples from bedrock fractures through which water moves along longer or slower flow paths. Apparent ages of groundwater from shallow bedrock wells (less than $15 \mathrm{~m}$ below bedrock surface) ranged from about 9 to 20 years and from deep bedrock wells, more than 50 years. The water produced at PSW-1 is derived from various land-use settings, but a major portion of groundwater is young (less than 7 years) and is derived from recharge in residential, commercial, and forested land-use areas.

An inverse relationship exists between estimated groundwater age and estimated recharge temperature in wells in the study area. The difference in estimated recharge temperatures may result from (1) warm groundwater recharge in the urbanized valley bottom that results from stormwater runoff over impervious surfaces during warm months and leachate from septic-tank drainfields; (2) a greater percentage of cool recharge that could originate in the predominantly forested uplands during the winter and spring rather than in the cleared and compacted soils of developed land at the valley bottom; and (3) a warming of the climate over the past 150 years, which in turn caused higher temperatures of the recharge, as opposed to older groundwater that was recharged at colder temperatures in a cooler climate. The colder recharge in the past is consistent with the decrease in delta oxygen-18 $\left(\delta^{18} \mathrm{O}\right)$ and delta hydrogen-2 $\left(\delta^{2} \mathrm{H}\right.$ or $\left.\delta \mathrm{D}\right)$ values observed with increasing groundwater age.

Several isotopic and other chemical tracers were analyzed in samples from wells in and near the modeled zone of contribution to help characterize the processes related to the source, transport, and pumping of PSW-1 that affect the movement of selected natural and anthropogenic constituents to PSW-1. The major sources and the indicative chemical characteristics or conditions used to identify them are (1) bedrock, and deep glacial stratified deposits and till, which affect water quality in the glacial aquifer - high $\mathrm{pH}$ and concentrations of sulfate $\left(\mathrm{SO}_{4}{ }^{2-}\right)$, bicarbonate $\left(\mathrm{HCO}_{3}^{-}\right)$, $\mathrm{U},{ }^{222} \mathrm{Rn}$, and As relative to the concentrations in other wells; reducing redox conditions, enriched delta sulfur-34 $\left(\delta^{34} \mathrm{~S}\right)$ values, depleted $\delta^{18} \mathrm{O}$ and $\delta \mathrm{D}$ values, calcite near saturation, low recharge temperatures, high concentrations of excess ${ }^{4} \mathrm{He}$, and older (greater than 9 years) groundwater relative to the groundwater in wells screened in shallow and intermediate glacial stratified deposits; (2) natural organic matter, either in sediments or in upgradient riparian zones - high concentrations of DOC, Fe, and (or) Mn, and low concentrations of $\mathrm{DO}$ and (or) nitrate $\left(\mathrm{NO}_{3}^{-}\right)$(reducing redox conditions), and enriched $\delta^{34} \mathrm{~S}$ values; (3) road salt (halite) - high concentrations of $\mathrm{Na}^{+}, \mathrm{Cl}^{-}$, and $\mathrm{Ca}^{2+}$, and indicative chloride/bromide $(\mathrm{Cl}: \mathrm{Br})$ mass concentration ratios; (4) septic-system leachate- high concentrations of $\mathrm{NO}_{3}^{-}$, DOC, sodium $\left(\mathrm{Na}^{+}\right)$, chloride $\left(\mathrm{Cl}^{-}\right)$, calcium $\left(\mathrm{Ca}^{2+}\right)$, and boron (B), delta nitrogen-15 $\left(\delta^{15} \mathrm{~N}\right)$, and $\delta^{18} \mathrm{O}$ values, and indicative $\mathrm{Cl}: \mathrm{Br}$ ratios; (5) organic solvent spills - detections of PCE, TCE, and 1,1-DCE; (6) gasoline station spills - detections of fuel oxygenates and benzene; and (7) surface-water leakageenriched ${ }^{18} \mathrm{O}$ and $\mathrm{D}$ values, seasonally high concentrations of DOC, and reducing conditions.

Water in fractured bedrock in the Pomperaug Basin typically contains high concentrations of sulfate $\left(\mathrm{SO}_{4}^{2-}\right)$ and $\mathrm{Na}$, which likely results from gypsum or anhydrite dissolution and cation exchange. Geochemical modeling was used to determine the contribution of water from underlying bedrock, primarily using $\mathrm{SO}_{4}{ }^{2-}$ and $\delta^{18} \mathrm{~S}_{\text {of }} \mathrm{SO}_{4}{ }^{2-}$ as end members; results of the model showed a substantial (up to 6 percent) contribution from underlying bedrock to the glacial aquifer. Mixing calculations based on geochemical modeling indicate that the water in PSW-1 is mainly composed of water similar 
in chemistry to the water in samples from monitoring well WY100, screened near the top of the PSW-1 screened interval; minor contributions to PSW-1 were from the center of the screened interval and from underlying bedrock, represented by the chemistry of water samples from WY101. The stratified nature of the glacial deposits results in thin sediment layers that are more permeable than adjacent zones and represent localized pathways for groundwater flow.

The urban land use in the contributing recharge area to PSW-1 coupled with the young groundwater (less than 7 years) result in a setting that is vulnerable to anthropogenic contamination. PSW-1 water contained low concentrations of the selected naturally occurring contaminants measured because of the overall scarcity of sources; the relatively small component of old water (greater than 50 years) with high concentrations of dissolved solids, which originated from underlying bedrock at this well, provides no health concern. There are, however, rock units outside the zone of contribution to PSW-1 in the Pomperaug Basin and elsewhere that contain high concentrations of $\mathrm{As}, \mathrm{U},{ }^{222} \mathrm{Rn}, \mathrm{Ra}, \mathrm{Fe}, \mathrm{Mn}$, and dissolved solids that could result in the locally high vulnerability of nearby supply wells completed in adjacent contributing areas and other glacial aquifers in the northeast. Glacial deposits derived from the Cass Formation in the Pomperaug Basin and other Newark Supergroup units in other Mesozoic basin settings, for example, could be sources of high As and U concentrations that affect drinking-water supply and may be a concern for human health.

\section{Acknowledgments}

The authors thank Larry Pond, Marc Taylor, Laurie Gianatti, Hunter Brawley, Dick Leavenworth, and several other members of the Pomperaug River Water Coalition who provided invaluable assistance with identifying historical land-use practices, assembling data from well-drilling records, and facilitating permissions or contacts for the drilling of monitoring wells or domestic-well sampling. They also coordinated meetings with the town, the State, and with local water companies. The authors also thank Kevin Moran and Gary Lord of United Water of Connecticut who generously provided access and historical information on public-supply fields, pumping, and water-quality data. Thanks go to Dave Monckton, director of public works for Woodbury who provided assistance with drilling locations and granted access to the old Trolley bed trail along South Brook. The authors appreciate USGS personnel who greatly contributed to the study, including, from the Connecticut Water Science Center, Timothy Frick, Karen Beaulieu, Jason Lewis, Justin Hudon, and David Bjerklie, and from the Geologic Discipline, Robert Zielinski, William Burton, and Janet Stone. Leon Kauffman provided invaluable assistance with intersecting particle-tracking results with GIS coverages. Finally, the authors thank the landowners who graciously provided access to their property for drilling, installation, and sampling of monitoring wells, or provided detailed information on their domestic wells.

\section{References Cited}

Agency for Toxic Substances and Disease Registry (ATSDR), 2006, Toxicological profile for dichlorobenzenes: Atlanta, Ga., U.S. Department of Health and Human Services, Public Health Service, 493 p., accessed August 20, 2007, at http://www.atsdr.cdc.gov/toxprofiles/tp10.pdf

Allen, H.E., Fu, G., Boothman, W., Di Toro, D.M., and Mahony, J.D., 1991, Determination of acid volatile sulfide and selected simultaneously extractable metals in sediment: U.S. Environmental Protection Agency 821-R-91-100, $18 \mathrm{p}$.

Allen, H.E., Fu, G., and Deng, B., 1993, Analysis of acidvolatile sulfide (AVS) and simultaneously extracted metals (SEM) for the estimation of potential toxicity in aquatic sediments: Environmental Toxicology and Chemistry, v. 12 , p. 1441-1453.

American Society for Testing and Materials, 1996, Annual book of ASTM standards, Standard test method for radon in drinking water: Philadelphia, Pa., American Society for Testing and Materials, D 5072-92, v. 11.01.

Appelo, C.A.J., and Postma, Dieke, 1993, Geochemistry, groundwater and pollution: Rotterdam, Netherlands, A.A. Balkema, $536 \mathrm{p}$.

April, R. H., 1981, Clay petrology of the Upper TriassicLower Jurassic terrestrial strata of the Newark Supergroup, Connecticut Valley, U.S.A.: Sedimentary Geology, v. 29, p. 283-307.

Arbogast, B.F., ed., 1990, Quality assurance manual for the Branch of Geochemistry, U.S. Geological Survey: U.S. Geological Survey Open-File Report 90-668, 184 p.

Ayotte, J.D., Flanagan, S.M., and Morrow, W.J., 2007, Occurrence of uranium and ${ }^{222}$ radon in glacial and bedrock aquifer systems in the northern United States, 1993-2003: U.S. Geological Survey Scientific Investigations Report 2007-5037, 84 p.

Barbash, J.S., Thelin, G.P., Kolpin, D.W., and Gilliom, R.J., 1999, Distribution of major herbicides in groundwater of the United States: U.S. Geological Survey Water-Resources Investigations Report 98-4245, 57 p.

Behl, E., Davis, S.N., and Goldowitz, J., 1987, Cl/Br ratios as an environmental tracer of anthropogenically altered waters: Geological Society of America Abstracts with Programs, v. 19, p. 585. 
Böhlke, J.K., 2002, Groundwater recharge and agricultural contamination: Hydrogeology Journal, v.10, p. 153-179.

Böhlke, J.K., 2005, C. Tracermodel 1-Excel workbook for calculation and presentation of environmental tracer data for simple groundwater mixtures, in International Atomic Energy Agency guidebook on the use of chlorofluorocarbons in hydrology: Vienna, International Atomic Energy Agency, p. 202-206.

Bowles, K.C., Ernste, M.J., and Kramer, J.R. 2003, Trace sulfide determination in oxic fresh waters: Analytica Chimica Acta, v. 477, p. 113-124.

Brenna, J.T., Corso, T.N., Tobias, H.J., and Caimi, R.J., 1997, High-precision continuous-flow isotope ratio mass spectrometry: Mass Spectrometry Reviews, v. 16, p. 227-258.

Brenton, R.W., and Arnett, T.L., 1993, Methods of analysis by the U.S. Geological Survey National Water Quality Laboratory-Determination of dissolved organic carbon by UV-promoted persulfate oxidation and infrared spectrometry: U.S. Geological Survey Open-File Report 92-480, 12 p.

Brown, C.J., and Chute, S.K., 2002, Arsenic in bedrock wells in Connecticut: U.S. Geological Survey Water-Resources Investigations Report 02-4135, 23 p.

Brown, C.J., and Starn, J.J., 2007, Groundwater sources and pathways to a public-supply well in a glacial aquifer system [abst.], Woodbury, Connecticut, 2007 Groundwater Summit: National Groundwater Association, Albuquerque, New Mexico, April 30-May 3, 2007.

Brown, C.J., and Zielinski, R.A., 2004, Occurrence and distribution of arsenic and uranium in the Pomperaug aquifer, Woodbury, Connecticut [abst.], Geology of Long Island and Metropolitan New York, April 17, 2004, Program with Abstracts: Stony Brook, N.Y., Long Island Geologists.

Brown, C.J., Jurgens, B.C., Katz, B.G., Landon, M.K., Eberts, S.M., 2007, Arsenic and uranium in four aquifer settings: occurrence, distribution, and mechanisms for transport to supply wells, NGWA Naturally Occurring Contaminants Conference-Arsenic, Radium, Radon, Uranium: Charleston, South Carolina, March 22 - 23, 2007. (http:// oh.water.usgs.gov/tanc/pubs/Brown_cj_2007_NatContam. pdf)

Brown, C.J., McMahon, P.B., and Starn, J.J., 2006, Effects of organic carbon distribution on redox chemistry in a glacial aquifer, Woodbury, Connecticut [abst.], National WaterQuality Monitoring Council's (NWQMC) 5th National Water-Quality Monitoring Council meeting, May 7-11, 2006, San Jose, Calif.
Bullister J.L., 1984, Atmospheric chlorofluoromethanes as tracers of ocean circulation and mixing-Studies in the Greenland and Norwegian seas: San Diego (La Jolla), Calif., University of California, Ph.D. dissertation, 172 p.

Bullister, J.L., and Weiss, R.F., 1988, Determination of $\mathrm{CCl}_{3} \mathrm{~F}$ and $\mathrm{CClF}_{2}$ in seawater and air: Deep-Sea Research, v. 35, no. 5, p. 839-854.

Burton, W.C., 2006, Bedrock geologic map of the Early Mesozoic Pomperaug Basin and surrounding basement rocks, Litchfield and New Haven Counties, Connecticut: U.S. Geological Survey Open-File Report 2006-1011, scale 1:12,000.

Burton, W.C., Huber, Phillip, McHone, J.G., and LeTourneau, P.M., 2005, A new look at the structure and stratigraphy of the early Mesozoic Pomperaug Basin, southwestern Connecticut, in McHone, N.W., and Peterson, M.J. eds., Guidebook for fieldtrips in Connecticut: Hartford, State Geological and Natural History Survey of Connecticut Guidebook, v. 8, p. C3-1-C3-43.

Busenberg, Eurybiades, and Plummer, L.N., 1992, Use of chlorofluorocarbons $\left(\mathrm{CCl}_{3} \mathrm{~F}\right.$ and $\left.\mathrm{CCl}_{2} \mathrm{~F}_{2}\right)$ as hydrologic tracers and age-dating tools - The alluvium and terrace system of central Oklahoma: Water Resources Research, v. 28, no. 9, p. 2257-2283.

Busenberg, Eurybiades, Plummer, L.N., Bartholomay, R.C., and Wayland, J.E., 1998, Chlorofluorocarbons, sulfur hexafluoride, and dissolved permanent gases in groundwater from selected sites in and near the Idaho National Engineering and Environmental Laboratory, Idaho, 1994-97: U.S. Geological Survey Open-File Report 98-274, (DOE/ID-22151), 72 p.

Busenberg, Eurybiades, and Plummer, L.N., 2000, Dating young groundwater with sulfur hexafluoride-Natural and anthropogenic sources of sulfur hexafluoride: Water Resources Research, v. 36, p. 3011-3030.

Canfield, D.E., Raiswell, R., Westrich, J.T., Reaves, C.M., and Berner, R.A., 1986, The use of chromium reduction in the analysis of reduced inorganic sulfur in sediments and shales: Chemical Geology, v. 54, p. 149-155.

Carmody, R.W., Plummer, L.N., Busenberg, Eurybiades, and Coplen, T.B., 1998, Methods for collection of dissolved $\mathrm{SO}_{4}{ }^{2-}$ and sulfide and analysis of their sulfur isotopic composition: U.S. Geological Survey Open-File Report 97-234, $91 \mathrm{p}$.

Casciotti, K.L., Sigman, D.M., Hastings, M.G., Böhlke, J.K., and Hilkert, A., 2002, Measurement of the oxygen isotopic composition of nitrate in seawater and freshwater using the denitrifier method: Analytical Chemistry, v. 74, p. 4905-4912. 
Center for Land Use Education and Research (CLEAR), 2003, The University of Connecticut, accessed on July 3, 2007, at http://clear.uconn.edu/projects /landscape/index.htm

Chapelle, F.H., McMahon, P.B., Dubrovsky, N.M., Fujii, R.F., Oaksford, E.T., and Vroblesky, D.A., 1995, Deducing the distribution of terminal electron-accepting processes in hydrologically diverse groundwater systems: Water Resources Research, v. 31, no. 2, p. 359-371.

Clark, I.D., and Fritz, Peter, 1997, Environmental isotopes in hydrogeology: New York, CRC Press LLC, 328 p.

Clayton, R.N., Friedman, Ivan, Graff, D.L., Mayeda, T.K., Meents, W.F., and Shimp, N.F., 1966, The origin of saline formation waters-1. Isotopic composition: Journal of Geophysical Research, v. 71, p. 3869-3882.

Connecticut Department of Environmental Protection, 2004, accessed on July 3, 2007 at http://www.ct.gov/dep/lib/dep/ air/mtbe/ 04waiver.pdf, State of Connecticut.

Connecticut Department of Public Health, 2007, State of Connecticut, accessed on July 9, 2007, at http://www.ct.gov/ dph/lib/dph/drinking_water/pdf/SWAPWEB_05_12.pdf.

Connelly, Peter, 2001, Environmental fate of fipronil: California Environmental Protection Agency, Department of Pesticide Regulation, accessed August 2, 2002 at http:// www.pw.ucf.edu/ textfiles/fipronil.pdf.

Connor, B.F., Rose, D.L., Noriega, M.C., Murtagh, L.K., and Abney, S.R., 1998, Methods of analysis by the U.S. Geological Survey National Water Quality LaboratoryDetermination of 86 volatile organic compounds in water by gas chromatography/mass spectrometry, including detections less than reporting limits: U.S. Geological Survey Open-File Report 97-829.

Cook, P.G., and Böhlke, J.K., 1999, Determining timescales for groundwater flow and solute transport, in Cook, P.G., and Herczeg, A.L., eds., Environmental tracers in subsurface hydrology: Boston, Mass., Kluwer Academic Publishers, p. 1-30.

Coplen, T.B., 1994. Reporting of stable hydrogen, carbon, and oxygen isotopic abundances: Pure and Applied Chemistry, v. 66 , p. $273-276$.

Coplen T.B., and Kendall, Carol, 2000, Stable hydrogen and oxygen isotope ratios for selected sites of the U.S. Geological Survey's NASQAN and Benchmark surfacewater networks: U.S. Geological Survey Open-File Report 00-160, 424 p. (http://water.usgs.gov/pubs/ofr/ofr00-160/ pdf/ofr00-160.pdf).

Coplen, T.B., Wildman, J.D., and Chen, Julie, 1991, Improvements in the gaseous hydrogen-water equilibration technique for hydrogen isotope ratio analysis: Analytical Chemistry, v. 63, p. 910-912.
Coveney, R.M., and Martin, S.P., 1983, Molybdenum and other heavy metals of the Mecca Quarry and Logan Quarry shales: Economic Geology, v. 78, no. 1, p. 132-149.

Craig, Harmon, 1961, Isotopic variations in meteoric waters: Science, v. 133, p. 1702-1703.

Czarnik, T.S., and Kozinski, Jane, 1994, Groundwater quality in the central part of the Passaic River basin, northeastern New Jersey, 1959-88: U.S. Geological Survey WaterResources Investigations Report 92-4083, 66 p.

Darling, W.G., and Bath, A.H., 1988, A stable isotope study of recharge processes in the English chalk: Journal of Hydrology, v. 101, p. 31-46.

Davis, J.A., Meece, D.E., Kohler, M., and Curtis, G.P., 2004, Approaches to surface complexation modeling of uranium (VI) adsorption on aquifer sediments: Geochimica et Cosmochimica Acta, no. 18, p. 3621-3641.

Davis, S.N., Whittemore, D.O., and Fabryka-Martin, J., 1998, Uses of chloride/bromide ratios in studies of potable water: Groundwater, v. 36, p. 338-350.

Dean, W.E., 1988, Inorganic geochemistry of fine-grained sedimentary rocks and hornfels in the Newark Supergroup, in Froelich, A.J., and Robinson, Jr., G.R., eds., Studies of the Early Mesozoic basins of the eastern United States: U.S. Geological Survey Bulletin 1176, p. 79-86.

Denver, J.M., and Sandstrom, M.W., 1991, Distribution of dissolved atrazine and two metabolites in the unconfined aquifer, southeastern Delaware, in Mallard, G.E., and Aronson, D.A., eds., U.S. Geological Survey Toxic Substances Hydrology Program-Proceedings of the technical meeting, Monterey, California, March 11-15, 1991: U.S. Geological Survey Water-Resources Investigations Report 91-4034, p. 324-318.

Dickneider, T.A., Murphy, S.M.E., Sallavanti, R.A., and Stephens, K.J., 1996, Organic geochemistry of exposures of the Shuttle Meadow and Portland Formations (Newark Supergroup), Connecticut, in LeTourneau, P.M., and Olsen, P.E., eds., Aspects of Triassic-Jurassic rift basin geoscience: State Geological and Natural History Survey of Connecticut Miscellaneous Reports, no. 1,9 p.

Doner, H.E., 1978, Chloride as a factor in mobilities of Ni(II), $\mathrm{Cu}(\mathrm{II})$, and $\mathrm{Cd}(\mathrm{II})$ in soil: Soil Science Society of America Journal, v. 42, no. 6, p. 882-885.

Drever, J.I., 2005, The geochemistry of natural waters (2d ed.): Englewood Cliffs, N.J., Prentice Hall, Inc., 388 p. 
Dupuy, C.J., Healy, D.F., Thomas, M.A., Brown, D.R., Siniscalchi, A.J., and Dembek, Z.F., 1991, A survey of naturally occurring radionuclides in groundwater in selected bedrock aquifers in Connecticut and implications for public health policy, in Gilbert, C.E., and Calabrese, E.J., eds., Regulating drinking water quality: Boca Raton, Florida, Lewis Publishers, p. 95-119.

Dzombak, D.A., and Morel, F.M.M., 1990, Surface complexation modeling-Hydrous ferric oxide: New York, John Wiley \& Sons, 416 p.

Eberts, S.M., Erwin, M.L., and Hamilton, P.A., 2005, Assessing the vulnerability of public-supply wells to contamination from urban, agricultural, and natural sources: U.S. Geological Survey Fact Sheet 2005-3022, 4 p.

El-Tabakh, M.C., Riccioni, Rita, and Schreiber, B.C., 1997, Evolution of late Triassic rift basin evaporites (Passaic Formation)_-Newark Basin, eastern North America: Sedimentology, v. 44, no. 4, p. 767-790.

Epstein, Samuel, and Mayeda, Toshiko, 1953, Variation of ${ }^{18} \mathrm{O}$ content of waters from natural sources: Geochimica et Cosmochimica Acta, v. 4, no. 5, p. 213-224.

Faires, L.M., 1993, Methods of analysis by the U.S. Geological Survey National Water-Quality LaboratoryDetermination of metals in water by inductively coupled plasma-mass spectrometry: U.S. Geological Survey OpenFile Report 92-634, 28 p.

Faure, G., 1986. Principles of Isotope Geology, 2d ed., New York, John Wiley and Sons, 589 p.

Fishman, M.J., ed., 1993, Methods of analysis by the U.S. Geological Survey National Water-Quality LaboratoryDetermination of inorganic and organic constituents in water and fluvial sediments: U.S. Geological Survey OpenFile Report 93-125, 217 p.

Fishman, M.J., and Friedman, L.C., 1989, Methods for determination of inorganic substances in water and fluvial sediments: U.S. Geological Survey Techniques of WaterResources Investigations, book 5, chap. A1, 545 p.

Focazio, M.J., Welch, A.H., Watkins, S.A., Helsel, D.R., and Horn, M.A., 1999, A retrospective analysis on the occurrence of arsenic in groundwater resources of the United States and limitations in drinking-water-supply characterizations: U.S. Geological Survey Water-Resources Investigations Report 99-4279, 21 p.

Förstel, H., 1982, ${ }^{18} \mathrm{O} /{ }^{16} \mathrm{O}$ ratio of water in plants and their environment, in Schmidt, H.L., Förstel, H., and Heinzinger, K., eds., Stable isotopes: Amsterdam, The Netherlands, Elsevier, p. 503-516.

Fuge, R., 1969, Bromine, in Wedepohl, K.H., ed., Handbook of geochemistry, v. 2: Berlin, Germany, Springer-Verlag, p. 35-B1 to $35-\mathrm{I} 6$.
Garabedian, J.A., Gray, N.H., and Steinen, R.P., 1996, Secondary minerals in half-moon vesicles of the Mesozoic basalts of the Pomperaug Basin, in LeTourneau, P.M., and Olsen, P.E., eds., Aspects of Triassic-Jurassic rift basin geoscience: State Geological and Natural History Survey of Connecticut Miscellaneous Reports, no. 1, p. 13.

Gates, R.M., 1954, Bedrock geology of the Woodbury quadrangle: Connecticut Geological and Natural History Survey Quadrangle Report 3, 23 p., scale 1:31,680.

Gillham, R.W., 1996, In situ treatment of groundwaterMetal-enhanced degradation of chlorinated organic contaminants, in Aral, M.M., ed., Advances in groundwater pollution control and remediation: Boston, Mass., Kluwer Academic Publishers, p. 249-274.

Gilliom, R.J., Barbash, J.E., Crawford, C.G., Hamilton, P.A., Martin, J.D., Nakagaki, N., Nowell, L.H., Scott, J.C., Stackelberg, P.E., Thelin, G.P., and Wolock, D.M., 2006, Pesticides in the Nation's streams and groundwater, 1992-2001: U.S. Geological Survey Circular 1291, 150 p.

Goddard, E.N., Trask, P.D., de Ford, R.K., Rove, O.N., Singewald, J.T., Overbeck, R.M., 1951, Rock Color Chart: Boulder, Colorado, Geological Society of America.

Gottfried, R.M., and Kotra, R.K., 1988, Comparative mineralogy of clay-rich strata in selected early Mesozoic basins of the eastern United States: U.S. Geological Survey Bulletin 1776, p. 99-102.

Grady, S.J., and Mullaney, J.R., 1998, Natural and human factors affecting shallow water quality in surficial aquifers in the Connecticut, Housatonic, and Thames River Basins: U.S. Geological Survey Water-Resources Investigations Report 98-4042, 81 p.

Grady, S.J., and Weaver, M.F., 1989, Evaluation of groundwater quality in relation to land use for stratifieddrift aquifers in Connecticut, in Ragone, S.E., ed., Regional characterization of water quality, Proceedings of the Baltimore Symposium, May 1989: International Association of Hydrological Sciences, Publication 182, p. 19-29.

Granato, G.E., 1996, Deicing chemicals as a source of constituents in highway runoff: Washington D.C., Transportation Research Board, Transportation Research Record 1533, National Research Council, p. 50-58.

Gray, N.H., 1988, The origin of $\mathrm{Cu}$ occurrences in the Hartford Basin, in Froelich, A.J., and Robinson, Jr., G.R., eds., Studies of the Early Mesozoic basins of the eastern United States: U.S. Geological Survey Bulletin 1176, p. 341-349.

HACH Company, 2002, DR/2400 spectrophotometer procedures manual: Loveland, Colo., USA, 450 p. 
Harmon, J., Robertson, W.D., Cherry, J.A., and Zanini, L., 1996, Impacts on a sand aquifer from an old septic system — nitrate and phosphate: Groundwater, v. 34, no. 6, p. $1105-1114$.

Helsel, D.R., and Hirsch, R.M., 1995, Statistical methods in water resources: Amsterdam, The Netherlands, Elsevier Science Publishing, 529 p.

Hem, J.D., 1992, Study and interpretation of the chemical characteristics of natural water ( $3 \mathrm{~d}$ ed.): U.S. Geological Survey Water Supply Paper 2254, 263 p.

Heron, G., Christensen, T.H., and Tjell, J.C., 1994, Oxidation capacity of aquifer sediments: Environmental Science and Technology, v. 28, p. 153-158.

Hingston, F.J., Posner, A.M., Quirk, J.P., 1972, Anion adsorption by goethite and gibbsite- - I. The role of the proton in determining adsorption: Journal of Soil Science, v. 23 , no. 2, p.177-192.

Hinkle, S.R., Böhlke, J.K., Duff, J.H., Morgan, D.S., and Weick, R.J., 2007, Aquifer-scale controls on the distribution of $\mathrm{NO}_{3}{ }^{-}$and ammonium in groundwater near La Pine, Oregon, USA: Journal of Hydrology, v. 333, p. 486-503.

Hollocher, Kurt, and Yuskaitis, Amie, 1993, Chemical composition of surface and high-uranium well water, Lake Sunapee area, New Hampshire: Northeastern Geology, v. 15 , no. 2 , p. $159-169$.

Holser, W.T., and Kaplan, I.R., 1966, Isotope geochemistry of sedimentary sulfates: Chemical Geology, v. 1, p. 93-135.

Huber, Phillip, and Letourneau, P.M., 2006, Revised lithostratigraphy of the Norian-Hettangian Pomperaug Rift basin, western Connecticut - resolving a century-old conflict in geologic interpretation, in Harris, J.D., Lucas, S.G., Spielmann, J.A., Lockley, M.G., Milner, A.R.C., and Kirkland, J.I., eds., The Triassic-Jurassic terrestrial transition, New Mexico Museum of Natural History \& Science, p. 43-61.

Huber, Phillip, and MacDonald, N.G., 1992, Revised stratigraphy and paleontology of the early Mesozoic Pomperaug Basin (Newark Supergroup): Geological Society of America Abstract, v. 24, no. 7, p. 357-358.

Hubert, J.F, Feshbach-Meriney, P.E., Smith, M.A., 1992, The Triassic-Jurassic Hartford rift basin, Connecticut and Massachusetts-Evolution, sandstone diagenesis, and hydrocarbon history: AAPG Bulletin, v. 76, no.11, p.1710-1734.

Hubert, J.F., Reed, A.A., Dowdall, W.L., and Gilchrist, J.M, 1978, Guide to the Mesozoic redbeds of central Connecticut: State Geological and Natural History Survey of Connecticut Guidebook, no. 4, 129 p.
Hurtubise, D.O., and Puffer, J.H., 1983, Geochemistry and petrology of the Pomperaug Basin basalts, Connecticut [abs.]: Geological Society of America Abstracts with Program, v. 15, no. 1, p. 91.

Insightful Corporation, 2000, S-PLUS 6.1-Modern Statistics and Advanced Graphics, Users Guide: Cambridge, Mass., Insightful Corporation.

Ivahnenko, Tamara, and Barbash, J.E., 2004, Chloroform in the hydrologic system - sources, transport, fate, occurrence, and effects on human health and aquatic organisms: U.S. Geological Survey Scientific Investigations Report 2004-5137, 34 p.

Jagucki, M.L., and Darner, R.A., 2001, Groundwater quality in Geauga County, Ohio-Review of previous studies, status in 1999, and comparison of 1986 and 1999 data: U.S. Geological Survey Water-Resources Investigations Report 01-4160, $60 \mathrm{p}$.

Jones, P. D., New, M., Parker, D.E., Martin, S., and Rigor, I.G., 1999, Surface air temperature and its changes over the past 150 years: Reviews of Geophysics, v. 37, no. 2, p. 173-199.

Kauffman, L.J., Baehr, A.L., Ayers, M.A., and Stackelberg, P.E., 2001, Effects of land use and travel time on the distribution of nitrate in the Kirkwood-Cohansey aquifer system in southern New Jersey: U.S. Geological Survey Water-Resources Investigations Report 01-4117, 49 p., online at http://nj.usgs.gov/nawqa/linj/pdf/wrir_01-4117.pdf

Kendall, Carol, 1998, Tracing nitrogen sources and cycling in catchments, in Kendall, Carol, and McDonnell, J.J., eds., Isotope tracers in catchment hydrology: Amsterdam, the Netherlands, Elsevier Science B.V., p. 519-576.

Kendall, Carol, and Coplen, T.B., 2000, Distribution of oxygen-18 and deuterium in river waters across the United States: Hydrological Processes, v. 15, no. 7, p. 1363-1393.

Kish, J.L., Thurman, E.M., Scribner, E.A., and Zimmerman, L.R., 2000, Methods of analysis by the U.S. Geological Survey Organic Geochemistry Research GroupDetermination of selected herbicides, metabolites, and their degradation products in water using solid-phase extraction and gas chromatography/mass spectrometry: U.S. Geological Survey Open-File Report 00-385, 13 p.

Koteff, Carl, and Pessl, Fred, Jr., 1981, Systematic ice retreat in New England: U.S. Geological Survey Professional Paper 1179, $20 \mathrm{p}$.

Koterba, M.T., Wilde, F.D., and Lapham, W.W., 1995, Groundwater data-collection protocols and procedures for the National Water-Quality Assessment ProgramCollection and documentation of water-quality samples and related data: U.S. Geological Survey Open-File Report 95-399, $113 \mathrm{p}$. 
Kotra, R.K., Gottfried, R.M., Spiker, E.C., Romankiw, L.A., and Hatcher, P.G., 1988, Chemical composition and thermal maturity of kerogen and phytoclasts of the Newark Supergroup in the Hartford Basin, in Froelich, A.J., and Robinson, G.R., eds., Studies of the Early Mesozoic basins of the eastern United States: U.S. Geological Survey Bulletin 1776, p. 68-73.

Krauskopf, K.B., 1979, Introduction to geochemistry: New York, McGraw-Hill, 721 p.

Krieger, H.L., and Whittaker, E.L., 1980, Prescribed procedures for measurement of radioactivity in drinking water: U.S. Environmental Protection Agency, EPA/600/480-032, $142 \mathrm{p}$.

Krynine, P.D., 1950, Petrology, stratigraphy, and origin of the Triassic sedimentary rocks of Connecticut: Connecticut Geological and Natural History Survey Bulletin 73, 247 p.

Lapham, W.W., Wilde, F.D., and Koterba, M.T., 1995, Groundwater data-collection protocols and procedures for the National Water-Quality Assessment ProgramSelection, installation, and documentation of wells, and collection of related data: U.S. Geological Survey OpenFile Report 95-398, 69 p.

Lapham, W.W., Hamilton, P.A., and Myers, D.N., 2005, National Water-Quality Assessment Program-Cycle IIRegional assessments of aquifers: U.S. Geological Survey Fact Sheet 2005-3013, 4 p.

LeTourneau, P.M., and Huber, Phillip, 2006, Early Jurassic eolian dune field, Pomperaug Basin, Connecticut and related deposits - Stratigraphic framework, synrift, paleoclimatic context: Sedimentary Geology, v. 187, p. 63-81.

Lovley, D.R., and Phillips, E.J.P., 1987, Rapid assay for microbially reducible ferric iron in aquatic sediments: Applied Environmental Microbiology, v. 53, no. 7, p. 1536-1540.

Lyford, F.P., Carlson, C.S., Brown, C.J., and Starn, J.J., 2007, Hydrogeologic setting and groundwater flow simulation of the Pomperaug River Basin Regional Study Area, Connecticut, in Paschke, S.S., ed., 2007, Hydrogeologic settings and groundwater flow simulations for regional studies of the transport of anthropogenic and natural contaminants to public-supply wells - Studies begun in 2001: Reston, Va., U.S. Geological Survey Professional Paper 1737-A, p. 6-1-6-26.

Mackay, Donald, and Shiu, W.Y., and Ma, K.C., 1997, Illustrated handbook of physical-chemical properties and environmental fate for organic chemicals, Volume V, Pesticide Chemicals: New York, Lewis Publishers, 812 p.
Magdo, H.S., Forman, Joel, Graber, Nathan, Newman, Brooke, Klein, Kathryn, Satlin, Lisa, Amler, R.W., Winston, J.A., and Landrigan, P.J., 2007, Ground Rounds-Nephrotoxicity in a young child exposed to uranium from contaminated well water: National Institute of Environmental Health Sciences, Environmental Health Perspectives: Department of Interior, 10.1289/ehp.9707, 27 p.

Maloszewski, P., and Zuber, A., 1982, Determining the turnover time of groundwater systems with the aid of environmental tracers. 1. Models and their applicability: Journal of Hydrology, v. 57, no. 3, p. 333-358.

Mazzaferro, D.L., 1986a, Groundwater availability and water quality in Southbury and Woodbury, Connecticut: U.S. Geological Survey Water-Resources Investigations Report 84-4221, $105 \mathrm{p}$.

Mazzaferro, D.L., 1986b, Depth to bedrock, depth to the water table, and classification of unconsolidated materials above the water table in stratified-drift areas of part of the Pomperaug River valley, Southbury and Woodbury, Connecticut: U.S. Geological Survey Miscellaneous Investigations Series Map I-1690, scale 1:24,000.

McCrea, J.M., 1950, On the isotopic chemistry of carbonates and a paleotemperature scale: Journal of Chemical Physics, v. 18, p. $849-857$.

McMahon, P.B., Böhlke, J.K., Kauffman, L.J., Kipp, K.L., Landon, M.K., Crandall, C.A., Burow, K.R., and Brown, C.J., 2008, Source and transport controls on the movement of nitrate to public supply wells in selected principal aquifers of the United States: Water Resources Research, v. 44.

Merino, Enrique, Gierre, J.P., and May, M.T., 1997, Diagenetive mineralogy, geochemistry, and dynamics of Mesozoic arkoses, Hartford rift basin, Connecticut, U.S.A.: Journal of Sedimentary Petrology, v. 105, no. 2, p. 93-106.

Montgomery, J.H., and Welkom, L.M., 1990, Groundwater chemicals desk reference: Chelsea, Michigan, Lewis Publishers, Inc., 640 p.

Moran, M.J., Zogorski, J.S., and Squillace, P.J., 2007, Chlorinated solvents in groundwater of the United States: Environmental Science and Technology, v. 41, p. 74-81.

Murphy, B.L., and Morrison, R.D., 2004, Introduction to environmental forensics: London, Elsevier Academic Press, $560 \mathrm{p}$.

NADP (National Atmospheric Deposition Program), 2007, NADP/NTN Monitoring Stations, accessed November 25, 2007, at http://nadp.sws.uiuc.edu/sites/ntnmap.asp?

Nolan, B.T., Ruddy, B.C., Hitt, K.J., and Helsel, D.R., 1998, A national look at nitrate contamination of groundwater: Water Conditioning and Purification, v. 39, p. 76-79. 
Norris, J.C., 1997, Toxicity summary for

1,4-dichlorobenzene-The risk assessment information system: Oak Ridge National Laboratory, accessed May 25, 2007, at http://rais.ornl.gov/tox/profiles/1_4_ dichlorobenzene c V1.shtml

Noss, R.R., Drave, R., and Mossman, C., 1987, Septic tank cleaners-Their effectiveness and impacts on groundwater quality: The Environmental Institute at the University of Massachusetts at Amherst, prepared for the Office of Research and Standards, Massachusetts Department of Environmental Quality Engineering Publication no. 87-3.

Panno, S.V., Hackley, K.C., Hwang, H.H., Greenberg, S.E., Krapac, I.G., Landsberger, S., and O'Kelly, D.J., 2006, Characterization and identification of $\mathrm{Na}-\mathrm{Cl}$ sources in groundwater: Groundwater, v. 44, no. 2, p. 176-187.

Parkhurst, D.L. and Appelo, C.A.J., 1999, User's guide to PHREEQC (Version 2) -A computer program for speciation, batch-reaction, one-dimensional transport, and inverse geochemical calculations: U.S. Geological Survey Water-Resources Investigations Report 99-4259, 310 p.

Paschke, S.S., Kauffman, L.J., Eberts, S.M., Hinkle, S.R., 2007, Hydrogeologic settings and groundwater flow simulations for regional studies of the transport of anthropogenic and natural contaminants to public-supply wells-Studies begun in 2001: U.S. Geological Survey Professional Paper 1737, Chapters A-H, 244 p.

Patton, C.J., and Kryskalla, J.R., 2003, Methods of analysis by the U.S. Geological Survey National Water-Quality Laboratory-Evaluation of alkaline persulfate digestion as an alternative to kjeldahl digestion for determination of total and dissolved nitrogen and phosphorus in water: U.S. Geological Survey Water-Resources Investigations Report 03-4174, $33 \mathrm{p}$.

Peavy, H.S., 1978, Groundwater pollution from septic tank drainfields-A report to the Blue Ribbons of the Big Sky Country Areawide Planning Organization: Bozeman, Mont., Dept. of Civil Engineering and Engineering Mechanics, Montana State University, p.

Pessl, Fred, Jr., 1970, Surficial geologic map of the Woodbury quadrangle, Litchfield and New Haven Counties, Connecticut: U.S. Geological Survey Geological Quadrangle Map GQ-896, scale 1:24,000.

Philpotts, A.R., Carroll, M., and Hill, J.M., 1996, Crystalmush compaction and the origin of pegmatitic segregation sheets in a thick flood-basalt flow in the Mesozoic Hartford Basin, Connecticut: Journal of Petrology, v. 97, p. 811-836.
Plummer, L.N., Böhkle, J.K., and Busenberg, Eurybiades, 2003, Approaches for groundwater dating, in Lindsey, B.D., Phillips, S.W., Donnelly, C.A., Speiran, G.K., Plummer, L.N., Böhlke, J.K., Focazio, M.J., Burton, W.C., and Busenberg, Eurybiades, Residence times and nitrate transport in groundwater discharging to streams in the Chesapeake Bay watershed: U.S. Geological Survey WaterResources Investigations Report 03-4035, p. 12-24.

Plummer L.N., Busby, J.F., Lee, R.W., and Hanshaw, B.B., 1990, Geochemical modeling in the Madison aquifer in parts of Montana, Wyoming, and South Dakota: Water Resources Research, v. 26, p. 1981-2014.

Plummer L.N., Busenberg, Eurybiades, 1999, Chlorofluorocarbons, in Cook P.G., and Herczeg, A., eds., Environmental tracers in subsurface hydrology, chap. 15: Boston, Kluwer Academic Press, p. 441-478.

Plummer, L.N., Michel, R.L., Thurman, E.M., and Glynn, P.D., 1993, Environmental tracers for age-dating young groundwater, in Alley, W.M., ed., Regional groundwater quality, chap. 11: New York, Van Nostrand Reinhold, p. 255-294.

Plummer, L.N., Rupert, M.G., Busenberg, Eurybiades, and Schlosser, Peter, 2000, Age of irrigation water in groundwater from the Eastern Snake River Plain aquifer, south-central Idaho: Groundwater, v. 38, no. 2, p. 264-283.

Pollack, D.W., 1994, User's guide for MODPATH/ MOD-PATH-PLOT, Version 3-A particle tracking post-processing package for MODFLOW, the U.S. Geological Survey finite-difference groundwater flow model: U.S. Geological Survey Open-File Report 94-464, variously paginated.

Randall, A.D., 1996, Mean annual runoff, precipitation, and evapotranspiration in the glaciated northeastern United States, 1951-1980: U.S. Geological Survey Open-File Report 96-395, 2 plates.

Randall, A.D., 2001, Hydrogeologic framework of stratifieddrift aquifers in the glaciated northeastern United States Report: U.S. Geological Survey Professional Paper 1415-B, 179 p., 1 plate.

Reilly, T.E., and Pollock, D.W., 1993, Factors affecting areas contributing recharge to wells in shallow aquifers: U.S. Geological Survey Water-Supply Paper 2412, 21 p.

Révész, K.M., and Casciotti, K.L., 2007, Determination of the $\delta\left({ }^{15} \mathrm{~N} /{ }^{14} \mathrm{~N}\right)$ and $\delta\left({ }^{18} \mathrm{O} /{ }^{16} \mathrm{O}\right)$ of nitrate in water: RSIL Lab Code 2900, chap. C17, in Révész, Kinga, and Coplen, Tyler B., eds., Methods of the Reston Stable Isotope Laboratory: Reston, Va.: U.S. Geological Survey, Techniques and Methods, book 10, sec. C, chap. 17, 24 p. 
Révész, K.M, and Qi, H., 2006, Determination of the $\delta$ $\left({ }^{15} \mathrm{~N} /{ }^{14} \mathrm{~N}\right)$ and $\delta\left({ }^{13} \mathrm{C} /{ }^{12} \mathrm{C}\right)$ of total $\mathrm{N}$ and $\mathrm{C}$ in solids: RSIL Lab Code 1832, chap. C5, in Révész, Kinga, and Coplen, Tyler B., eds., Methods of the Reston Stable Isotope Laboratory: Reston, Va.: U.S. Geological Survey, Techniques and Methods, book 10, sec. C, chap. 5, 31 p.

Robertson, W.D., Cherry, J.A., and Sudicky, E.A., 1991, Groundwater contamination from two small septic systems on sand aquifers: Groundwater, v. 29, no. 1, p. 82-92.

Robinson, G.R., Jr., and Ayotte, J.D., 2006, The influence of geology and land use on arsenic in stream sediments and groundwaters in New England, USA: Applied Geochemistry, v. 21 p. 1482-1497.

Robinson, G.R., Jr., and Sears, C.M., 1988, Inventory of metal mines and occurrences associated with the early Mesozoic basins of the eastern United States - Summary tables, in Froelich, A.J., and Robinson, Jr., G.R. eds., Studies of the Early Mesozoic basins of the eastern United States: U.S. Geological Survey Bulletin 1176, p. 265-303.

Rodgers, John, comp., 1985, Bedrock geological map of Connecticut: Connecticut Geological and Natural History Survey, Natural Resources Atlas Series Map, 2 sheets, scale $1: 125,000$.

Rogers, R.J., 1989, Geochemical comparison of groundwater in areas of New England, New York, and Pennsylvania: Groundwater, v. 27, no. 5, p. 690-712.

Rozanski, K., Araguás-Araguás, L., and Gonfiantini, R., 1993, Isotopic patterns in modern global precipitation, in Swart, P.K., Lohmann, K.C., McKenzie, J. and Savin S., eds., Climate Change in Continental Isotopic Records: Geophysical Monograph 78, American Geophysical Union, p. $1-36$.

Satterlund, D.R., and Adams, P.W., 1992, Wildland watershed management, (2d ed.): New York, Wiley, 436 p.

Schlosser, Peter, Stute, Martin, Dorr, H., Sonntag, C., and Munnich, K.O., 1988, Tritium/ $/{ }^{3} \mathrm{He}$ dating of shallow groundwater: Earth and Planetary Science Letters, v. 89, p. 353-362.

Schlosser, Peter, Stute, Martin, Sonntag, C., and Munnich, K.O., 1989, Tritiogenic ${ }^{3} \mathrm{He}$ in shallow groundwater: Earth Planetary Science Letters, v. 94, p. 245-256.

Schoonen, M.A.A., Devoe, Vikki, and Brown, C.J., 1995, Bromide in Long Island groundwaters and surface waters, in Geology of Long Island and Metropolitan New York, April 22, 1995, Program with Abstracts: Stony Brook, New York, Long Island Geologists, p. 118-126.

Serfes, Michael, 2004, Arsenic in New Jersey groundwater: New Jersey Department of Environmental Protection, New Jersey Geological Survey Information Circular, 2 p.
Shapiro, A.M., 2002, Cautions and suggestions for geochemical sampling in fractured rock: Groundwater Monitoring and Remediation: v. 22, no. 3, p. 151-164.

Sigman, D.M., Casciotti, K.L, Andreani, M., Barvord, C., Galanter, M., and Bohlke, J.K., 2001, A bacterial method for the nitrogen isotopic analysis of nitrate in seawater and freshwater: Analytical Chemistry, v. 73, p. 4145-4153.

Soller, D.R., and Packard, P.H., 1998, Digital representation of a map showing the thickness and character of Quaternary sediments in the glaciated United States east of the Rocky Mountains: U.S. Geological Survey Digital Data Series DDS-38, CD-ROM.

Solomon, D.K., and Cook, P.G., 1999, ${ }^{3} \mathrm{H}$ and ${ }^{3} \mathrm{He}$, in Cook, P., and Herczeg, A., eds., Environmental tracers in subsurface hydrology: Boston, Kluwer Academic Publishers, p. $397-424$.

Sovereign Consulting, Inc., 2004a, Woodbury Mobil subsurface investigation report - Woodbury Mobil/ Middle Quarter Mall Area: Sandy Hook, Conn., Sovereign Consulting, Inc.

Sovereign Consulting, Inc., 2004b, Groundwater delineation addendum report—Woodbury Mobil/Middle Quarter Mall Area: Sandy Hook, Conn., Sovereign Consulting, Inc., 122 p.

Spiker, E.C., 1985, Stable-isotope characterization of organic matter in the Early Mesozoic basins of the eastern United States, in Robinson, G.R., Jr., and Froelich, A.J., eds., Proceedings of the Second U.S. Geological Survey Workshop on the Early Mesozoic Basins of the Eastern United States: U.S. Geological Survey Circular 946, p. 70-73.

Starn, J.J., and Brown, C.J., 2007, Simulations of groundwater flow and residence time near Woodbury, Connecticut, for a study of Transport of Anthropogenic and Natural Contaminants (TANC) to public-supply wells: U.S. Geological Survey Scientific Investigations Report 2007-5210, 45 p.

Starn, J.J., and Stone, J.R., 2005, Simulation of groundwater flow to assess geohydrologic factors and their effect on source-water areas for bedrock wells in Connecticut: U.S. Geological Survey Scientific Investigations Report 2004-5132, 78 p., online only at http://pubs.usgs.gov/ $\operatorname{sir} / 2004 / 5132 /$.

Stollenwerk, K.G., 2003, Geochemical processes controlling transport of arsenic in groundwater-A review of adsorption, in Welch, A.H., and Stollenwerk, K.G., eds., Arsenic in groundwater: Boston, Mass., Kluwer Academic Publishers, $475 \mathrm{p}$. 
Stone, J.R., Schafer, J.P., London, E.H., DiGiacomo-Cohen, Mary, Lewis, R.S., and Thompson, W.B., 2005, Quaternary geologic map of Connecticut and Long Island Sound basin, with a section on sedimentary facies and morphosequences of glacial meltwater deposits by B.D. Stone: U.S. Geological Survey Scientific Investigations Map 2784, 2 sheets.

Sturgeon, G.M., Davis, J.M., Linder, E., and Harter, R.D., 2006 Heterogeneities in glaciofluvial deposits using an example from New Hampshire: Groundwater, v. 44, no. 4, p. 528-539.

Suchecki, R.,K., Hubert, J.F., and Wet, C.C.B.D., 1988, Isotopic imprint of climate and hydrogeochemistry on terrestrial strata of the Triassic-Jurassic Hartford and Fundy rift basins: Journal of Sedimentary Petrology, v. 58, p. $801-811$.

Szabo, Zoltan, and Zapecza, O.S., 1991, Geologic and geochemical factors controlling uranium, radium-226, and radon-222 in groundwater, Newark Basin, New Jersey, in Gunderson, L.C.S., and Wanty, R.B., eds., Field studies of radon rocks, soils, and water: U.S. Geological Survey Bulletin 1971, p. 243-265.

Tabakh, M.E., and Schreiber, B.C., 1998, Diagenesis of the Newark Rift basin, Eastern North America: Sedimentology, v. 45 , no. 5 , p. $855-874$

Thomas, M.A., 2000, The effect of residential development on groundwater quality near Detroit, Michigan: Journal of the American Water Resources Association, v. 36, no. 5, p. $1023-1038$.

Thomas, M.A., 2007, The association of arsenic with redox conditions, depth, and groundwater age in the glacial aquifer system of the northern United States: U.S. Geological Survey Scientific Investigations Report 2007-5036, 26 p.

Thomas, M.A., Hollis, J.N., Rothney, L.M., Toal, B.F., and Dupuy, C.J., 1988, Correlating radon distribution with geology and areal radioactivity in Connecticut: Northeastern Environmental Science, v. 7, p. 10.

Thomas, M.A., and McHone, 1997, Indoor radon potential map of Connecticut: Connecticut Departmental of Environmental Protection, map.

Trombley, T.J., Brown, C.J., and Delzer, G.C., 2007, Anthropogenic organic compounds in source and finished water from community water system wells in western and central Connecticut, 2002-2004: U.S. Geological Survey Scientific Investigations Report 2007-5171, 38 p.

Turner-Peterson, C.E., 1977, Uranium mineralization during early burial, Newark Basin, Pennsylvania-New Jersey, in Campbell, J.A., ed., Short papers of the U.S. Geological Survey Uranium-Thorium Symposium: U.S. Geological Survey Circular 753, p. 3-4.
U.S. Census Bureau, 2000, Census 2000, accessed October 20, 2007, at http://www.census.gov/main/www/cen2000.html.

U.S. Environmental Protection Agency, 1980, Prescribed procedures for measurements of radioactivity in drinking water-Gross alpha and gross beta radioactivity in drinking water, Method 900.0: United States Environmental Protection Agency, Environmental Monitoring and Support Laboratory.

U.S. Environmental Protection Agency, 1996, New pesticide fact sheet: Washington, D.C., USEPA Office of Prevention, Pesticides, and Toxic Substances, EPA 737-F-96-005, 10 p.

U.S. Environmental Protection Agency, 2006a, Title 40Protection of Environment, Chapter I Environmental Protection Agency, Part 141-National primary drinking water regulations, Washington, D.C., accessed October 20, 2007, at http://www.access.gpo.gov/nara/cfr/ waisidx_02/40cfr141_02.html

U.S. Environmental Protection Agency, 2006b, Title 40Protection of Environment, Chapter I Environmental Protection Agency, Part 143 - National secondary drinking water regulations, Washington, D.C., accessed on October 20, 2007, at http://www.access.gpo.gov/nara/cfr/ waisidx_02/40cfr143_02.html

U.S. Environmental Protection Agency, 2006c, Method 9030B-Acid-soluble and acid-insoluble sulfides distillation, accessed May 1, 2006, at http://www.epa.gov/ epaoswer/hazwaste/test/pdfs/9030b.pdf

van de Kamp, P. C., and Leake, B. E., 1996, Petrology, geochemistry, and Na metasomatism of Triassic-Jurassic non-marine clastic sediments in the Newark, Hartford, and Deerfield rift basins, northeastern USA: Chemical Geology, v. 133 , p. $89-124$.

Vengosh, Avner, and Pankratov, Irena, 1998, Chloride/bromide and chloride/fluoride ratios of domestic sewage effluents and associated contaminated groundwater: Groundwater, v. 36 , no. 5, p. 815-824.

Vine, J.D., and Tourtelot, E.B., 1970, Geochemical investigations of some black shales and associated rocks: U.S. Geological Survey Bulletin 1314-A, 43 p.

Warner, K.L., and Arnold, T.L., 2006, Framework for regional synthesis of water-quality data for the glacial aquifer system in the United States: U.S. Geological Survey Scientific Investigations Report 2005-5223, 6 p.

Weddle, T.K., and Hubert, J.F., 1983, Petrology of Upper Triassic sandstones of the Newark Supergroup in the northern Newark, Pomperaug, Hartford, and Deerfield basins: Northeastern Geology, v. 5, p. 8-22. 
Welch, A.H., Westjohn, D.B., Helsel, D.R., and Wanty, R.B., 2000, Arsenic in groundwater of the United StatesOccurrence and geochemistry: Groundwater, v. 38, no. 4, p. 589-604.

Williams, J.H. and Johnson, C.D., 2000, Borehole-wall imaging with acoustic and optical televiewers for fracturedbedrock aquifer investigations, in Proceedings of the 7th

Minerals and Geotechnical Logging Symposium, Golden, Colo., October 24-26, 2000, p. 43-53.

Zaugg, S.M., Sandstrom, M.W., Smith, S.G., Fehlberg, K.M., 1995, Methods of analysis by the U.S. Geological Survey National Water-Quality Laboratory-Determination of pesticides in water by $\mathrm{C}-18$ solid-phase extraction and capillary-column gas chromatography/mass spectrometry with selected-ion monitoring: U.S. Geological Survey Open-File Report 95-181, 49 p.
Ziegler, D.G., 1983, Hydrocarbon potential of the Newark Rift system-Eastern North America: Northeastern Geology, v. 5, p. 200-208.

Zimmermann U., Ehhalt D., Münnich K.O., 1967, Soil water movement and evapotranspiration - Changes in the isotope composition of water, in Isotopes in hydrology: Vienna, International Atomic Energy Agency, p. 567-84.

Zogorski, J.S., Carter, J.M., Ivahnenko, T., Lapham, W.W., Moran, M.J., Rowe, B.L., Squillace, P.J., and Toccalino, P.L., 2006, Volatile organic compounds in the Nation's groundwater and drinking-water supply wells: U.S. Geological Survey Circular 1292, 101 p.

Zuber, A., 1986, Mathematical models for the interpretation of environmental radioisotopes in groundwater systems, in Fritz, P., and Fontes, J.C., eds., Handbook of environmental geochemistry-The terrestrial environment, v. 2: New York, Elsevier, p. 1-59. 
This page has been left blank intentionally. 


\section{Appendix}

1. Depths of sediment and rock samples and description of texture and lithology, color, and sorting, from monitoring-well boreholes in the study area, Woodbury, Connecticut.

2. Gamma, fluid temperature, fluid conductivity, and caliper logs, and acoustic traveltime, acoustic televiewer amplitude, and optical televiewer images for bedrock monitoring wells WY86, WY87, WY97, and WY106 in relation to depth in the study area, Woodbury, Connecticut.

3. Quality-control summary for constituents detected in field blanks and percent recovery for surrogates in the study area, Woodbury, Connecticut, 2003-05.

4. Oxidation-reduction (redox) classification scheme developed for the transport of anthropogenic and natural contaminants to public-supply wells 


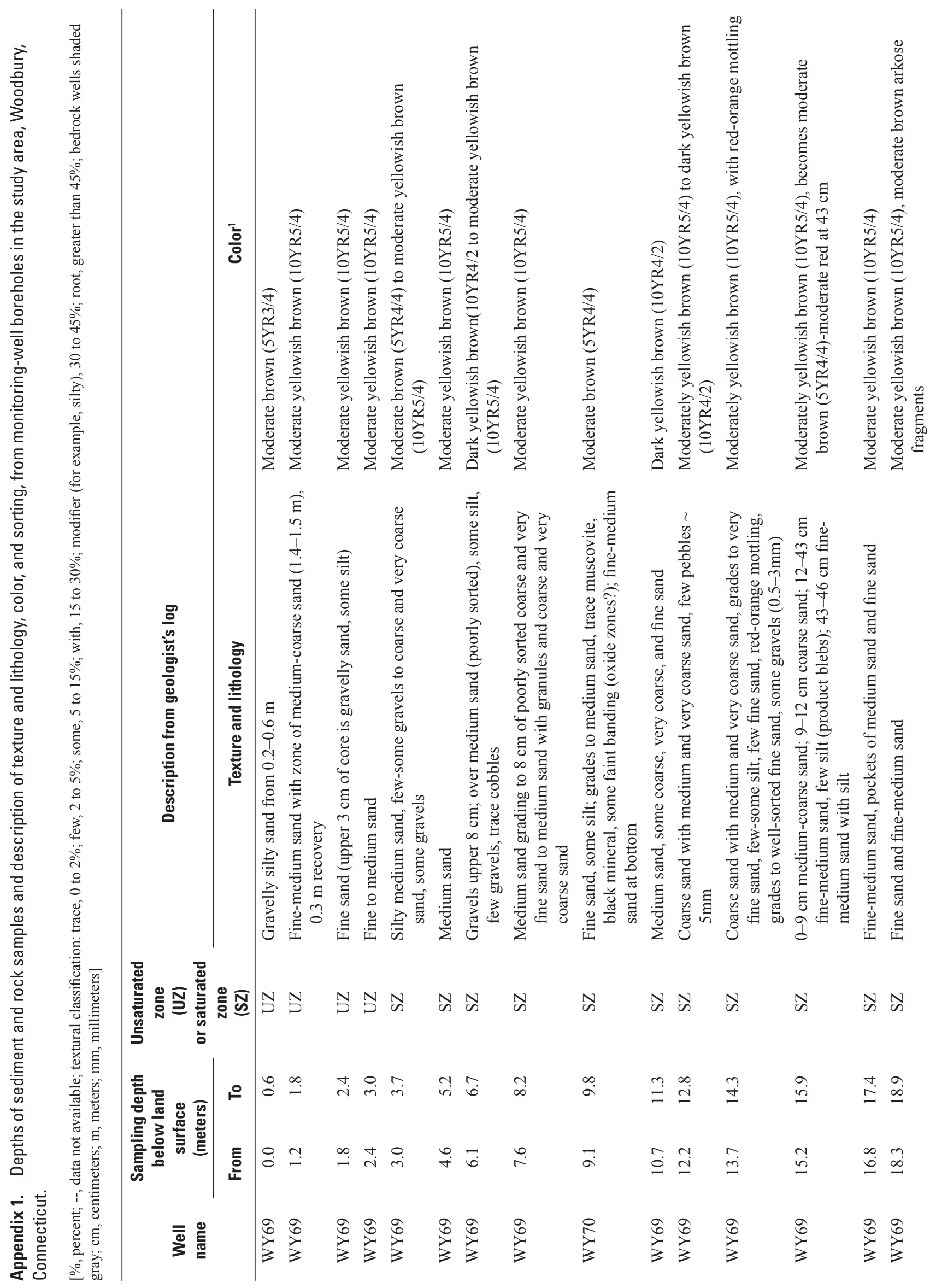




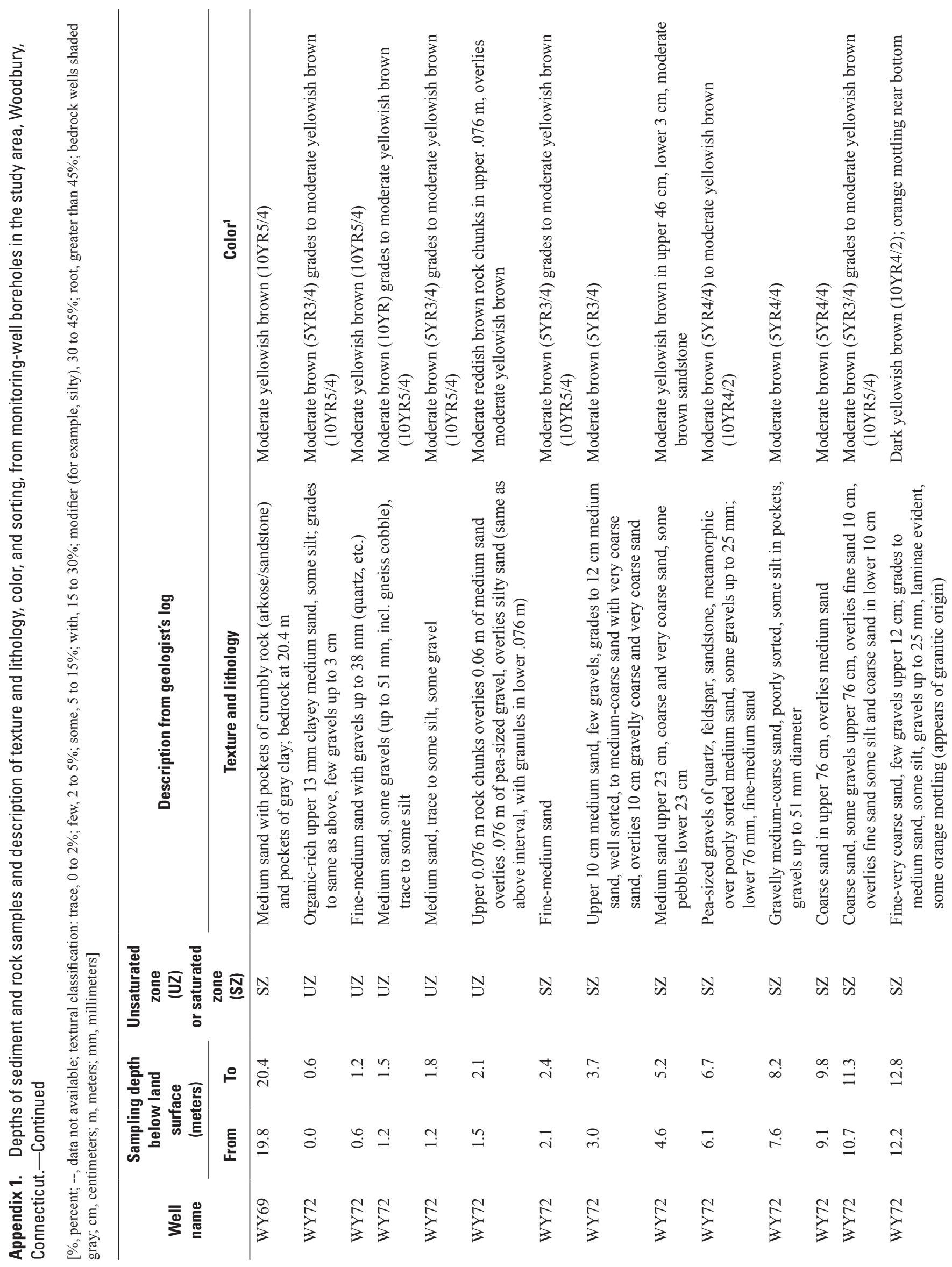




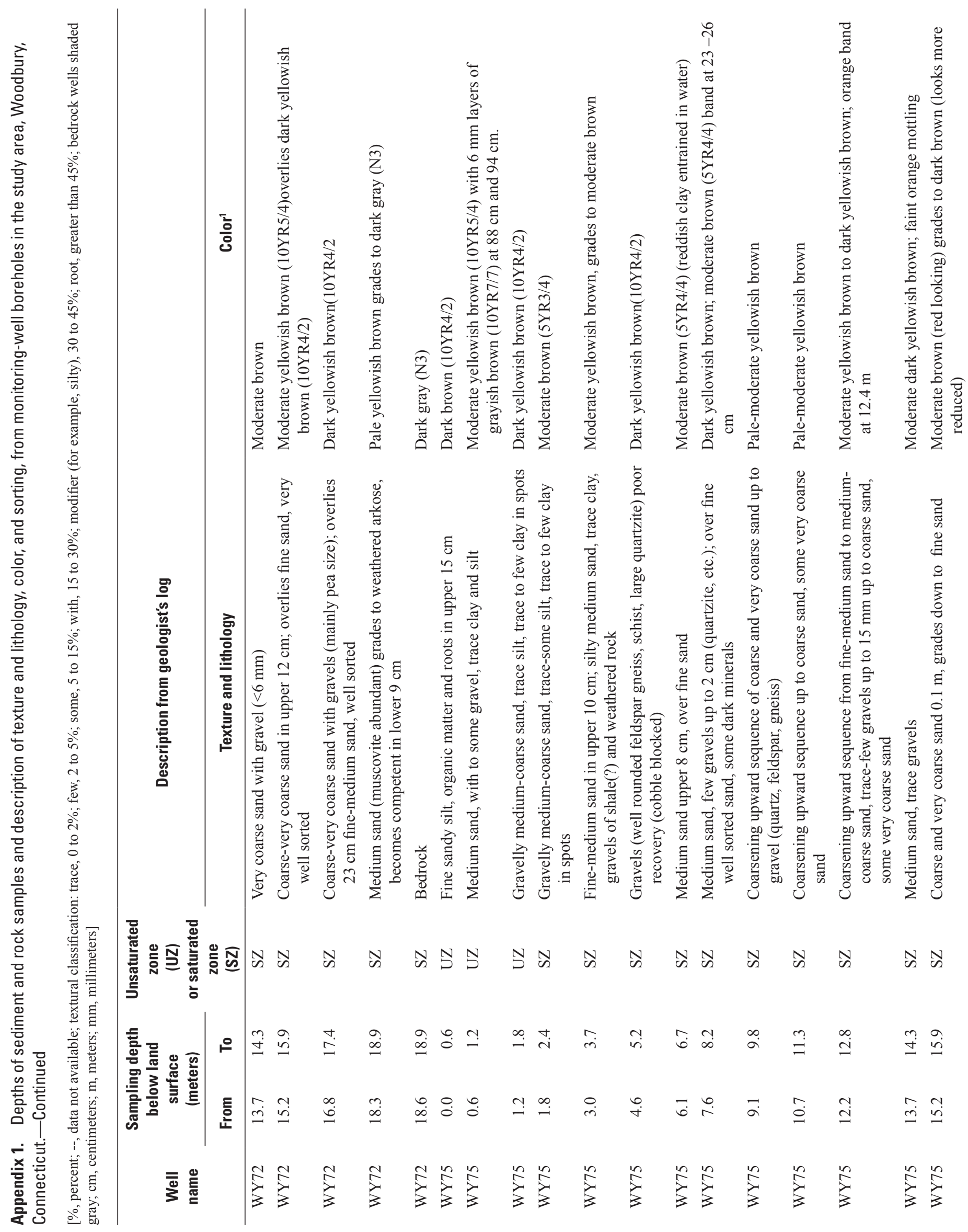




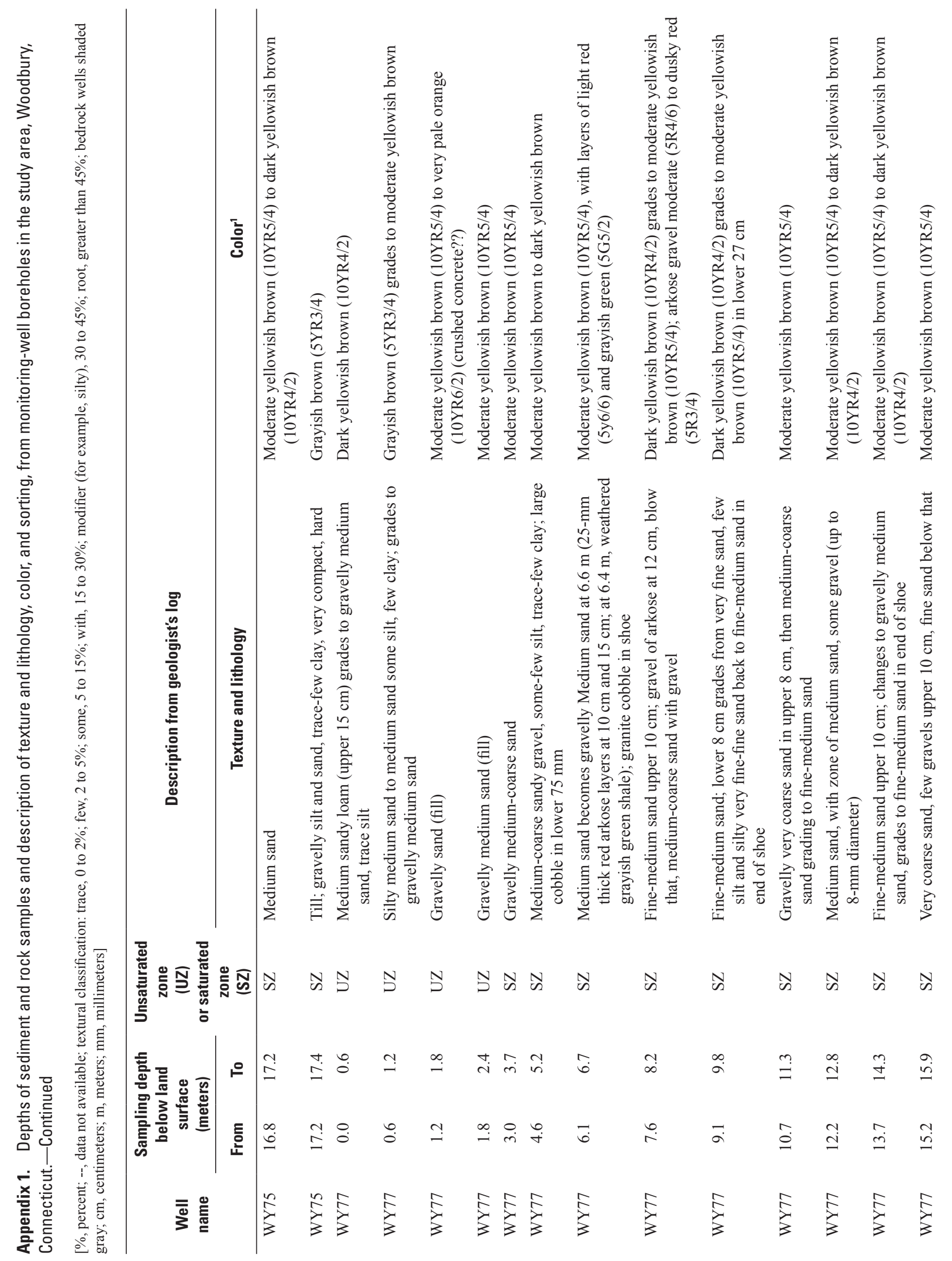




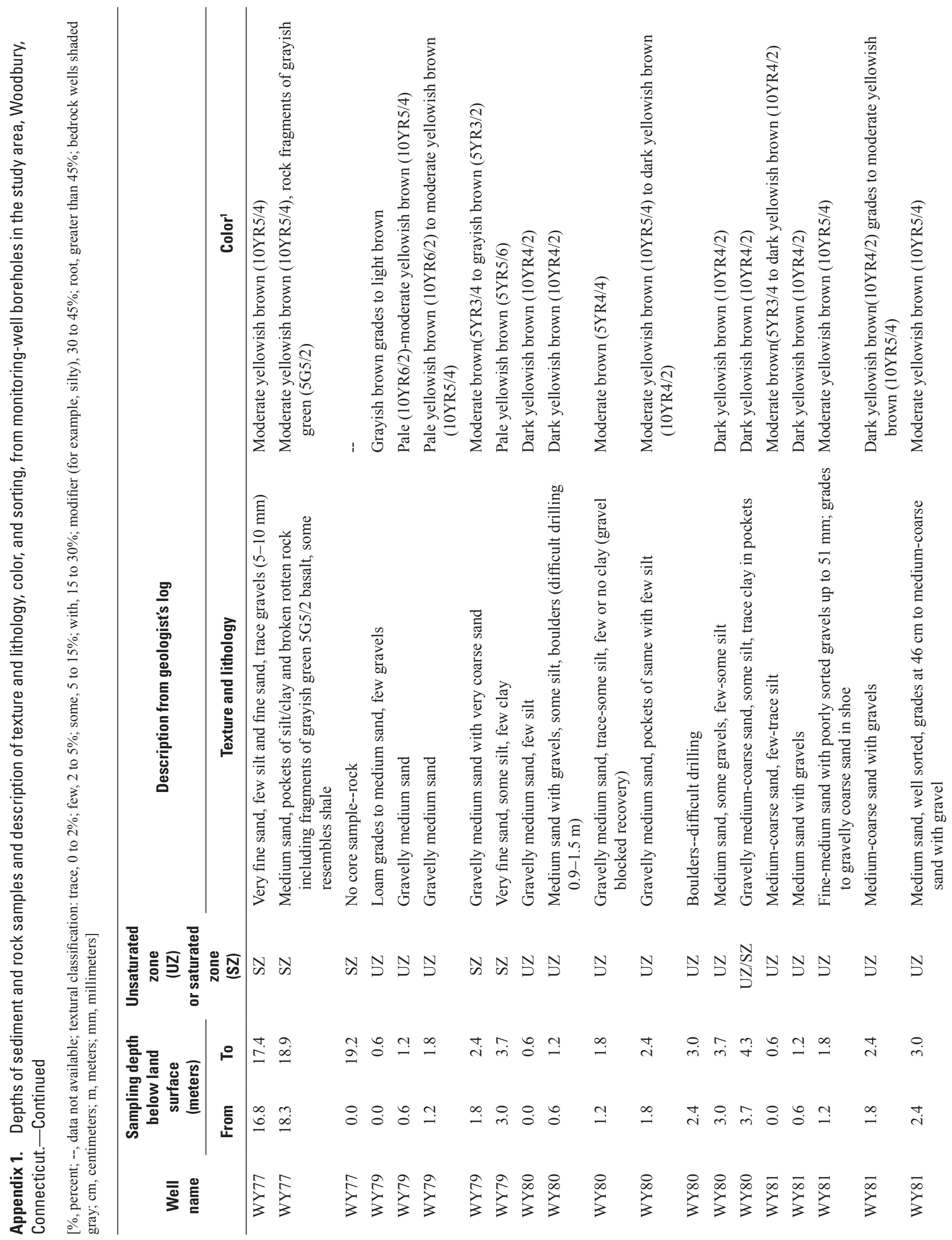




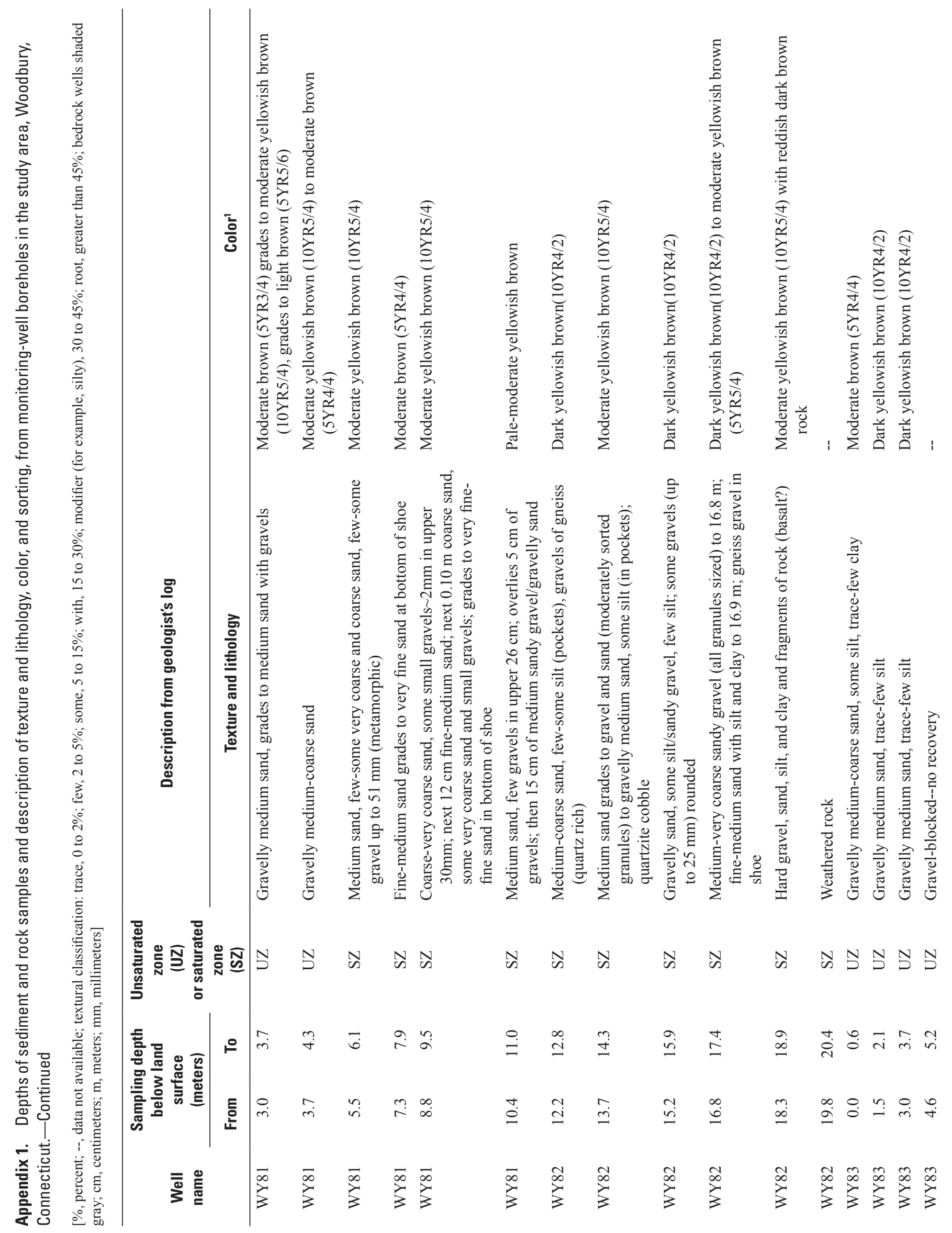




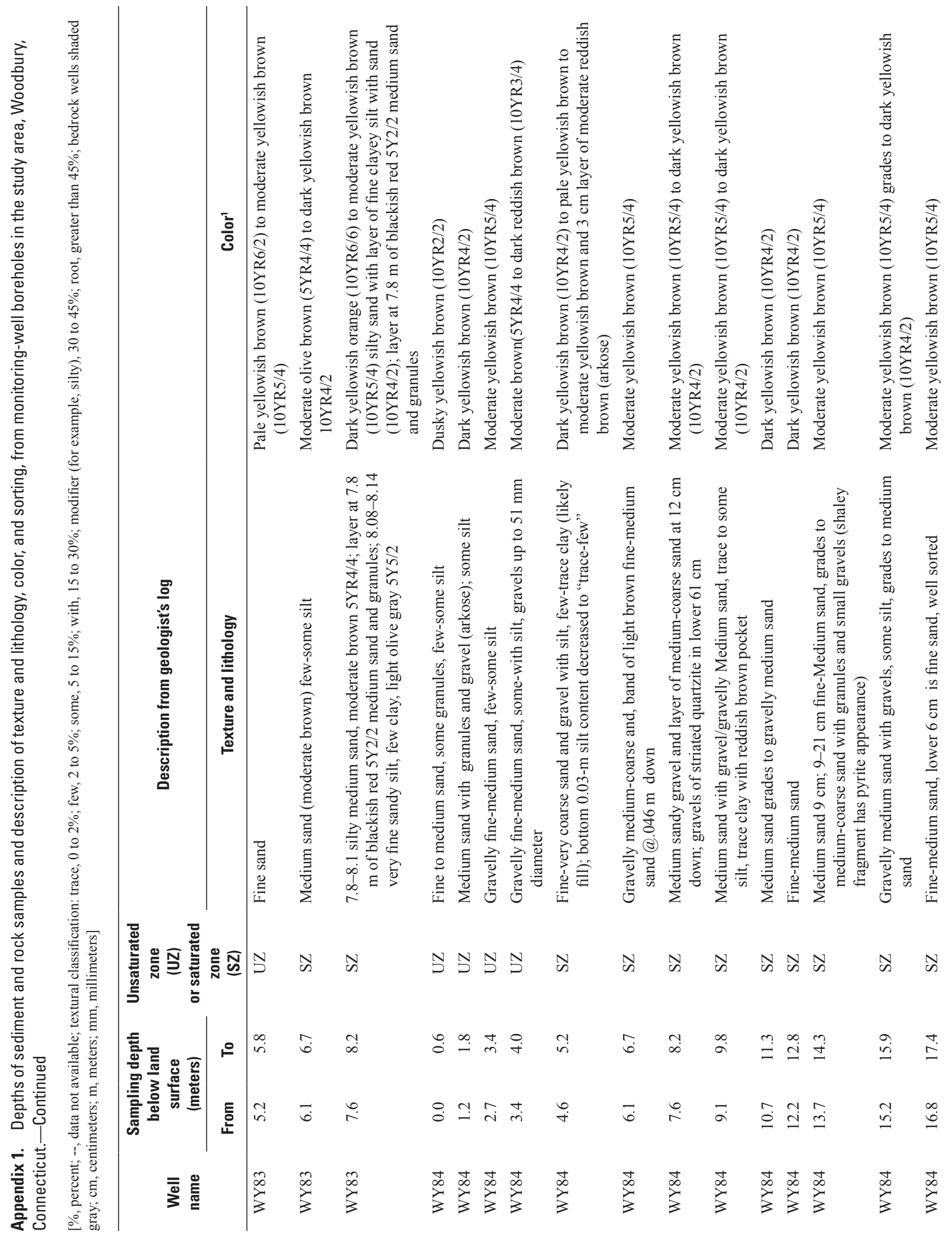




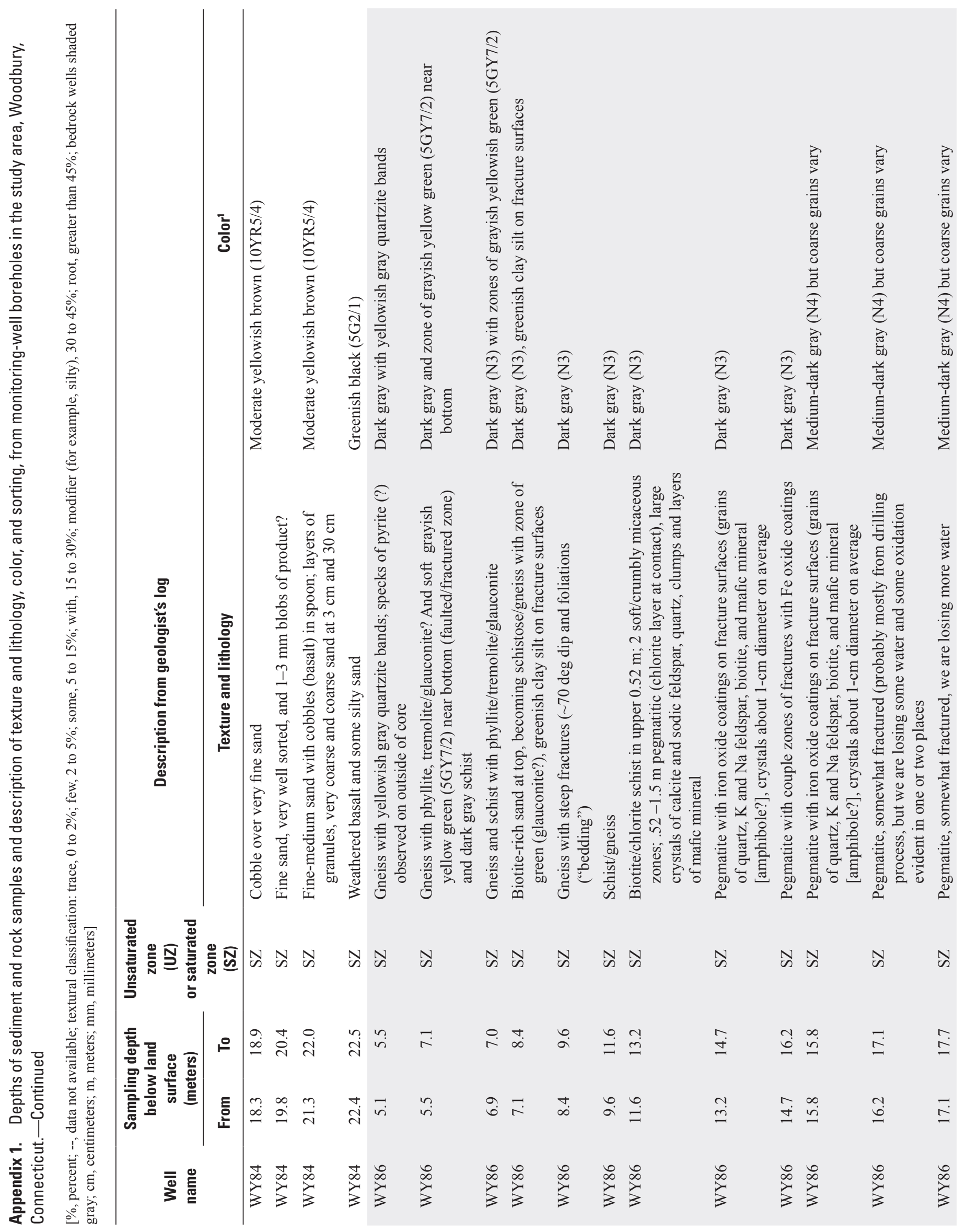




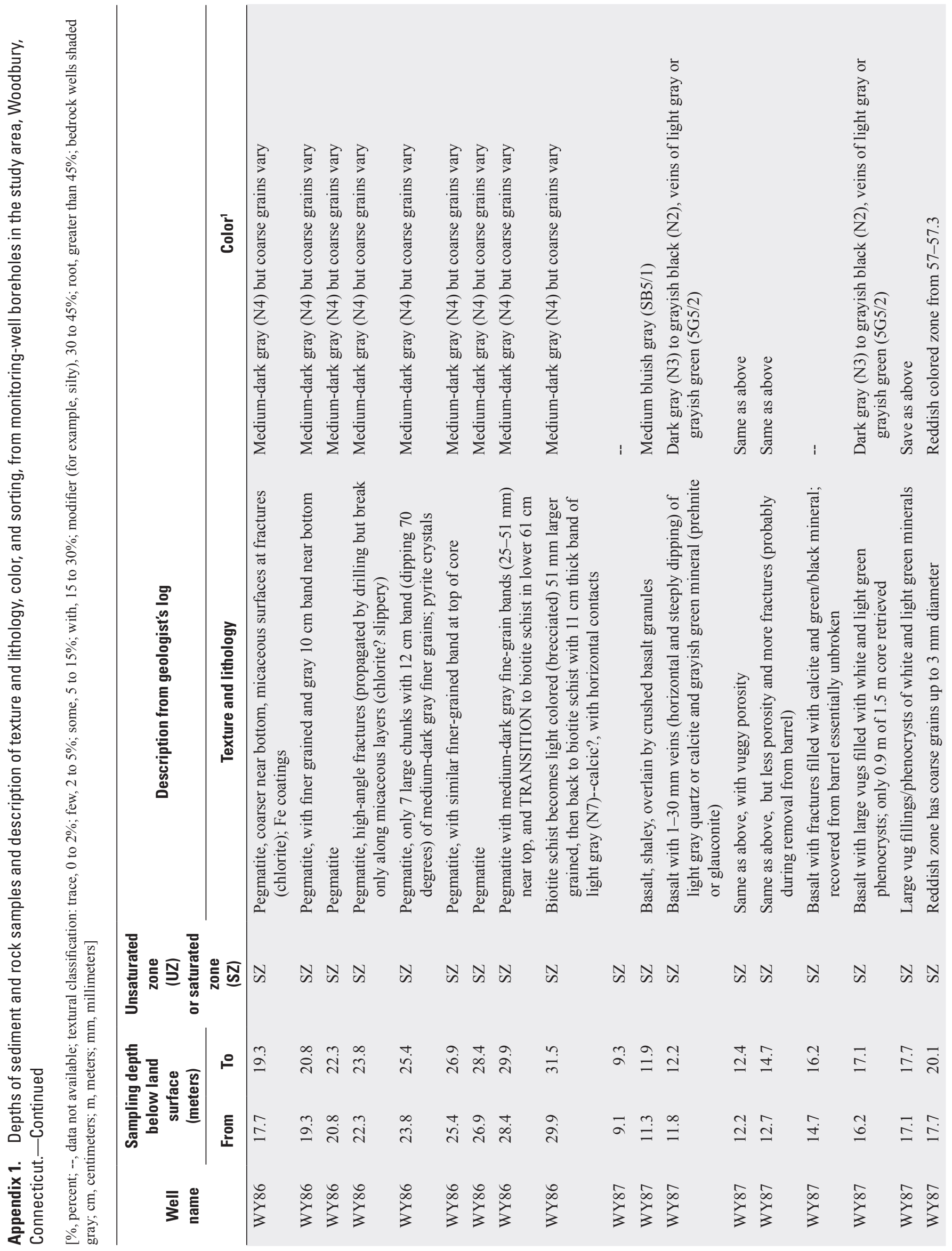




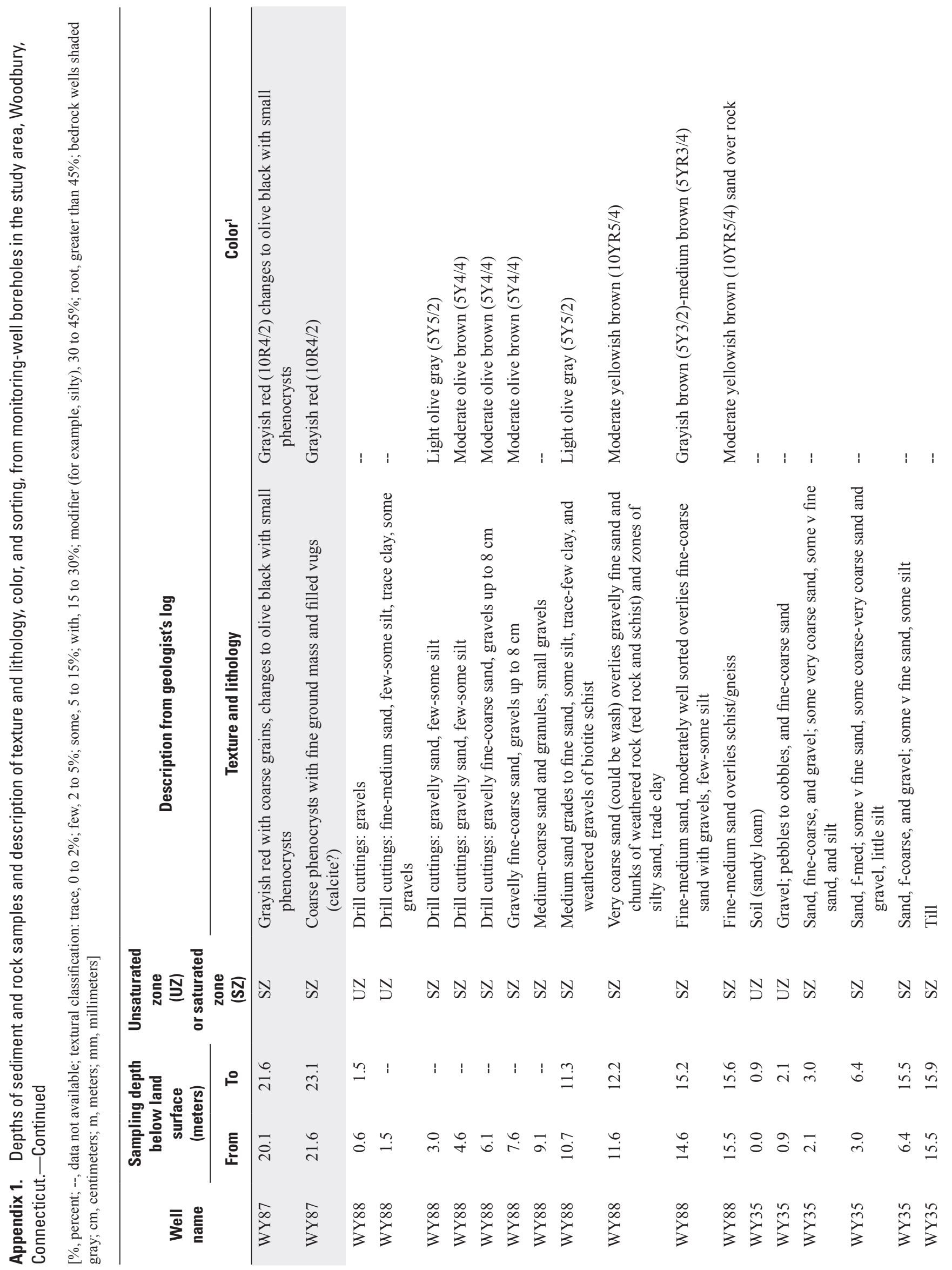




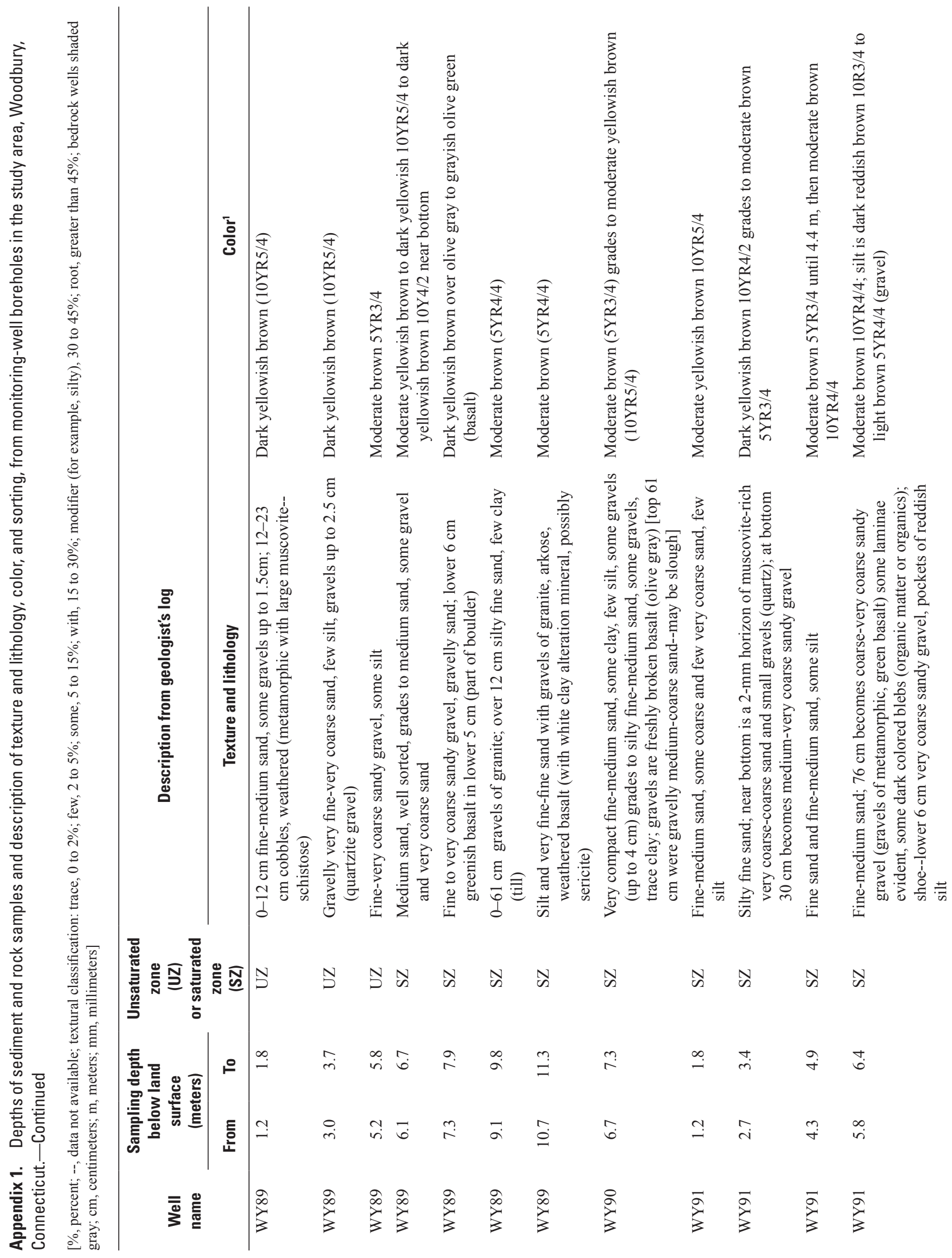




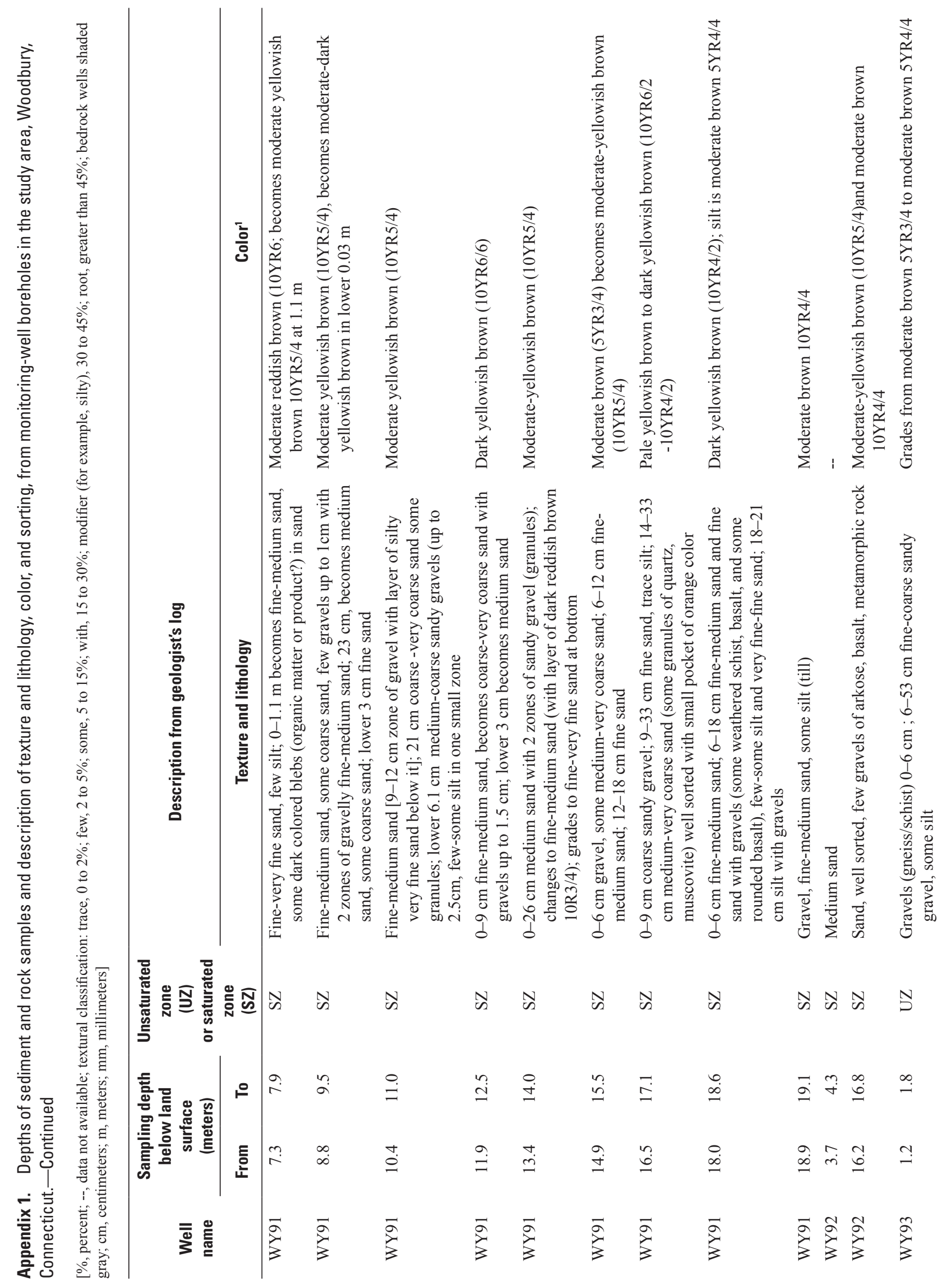




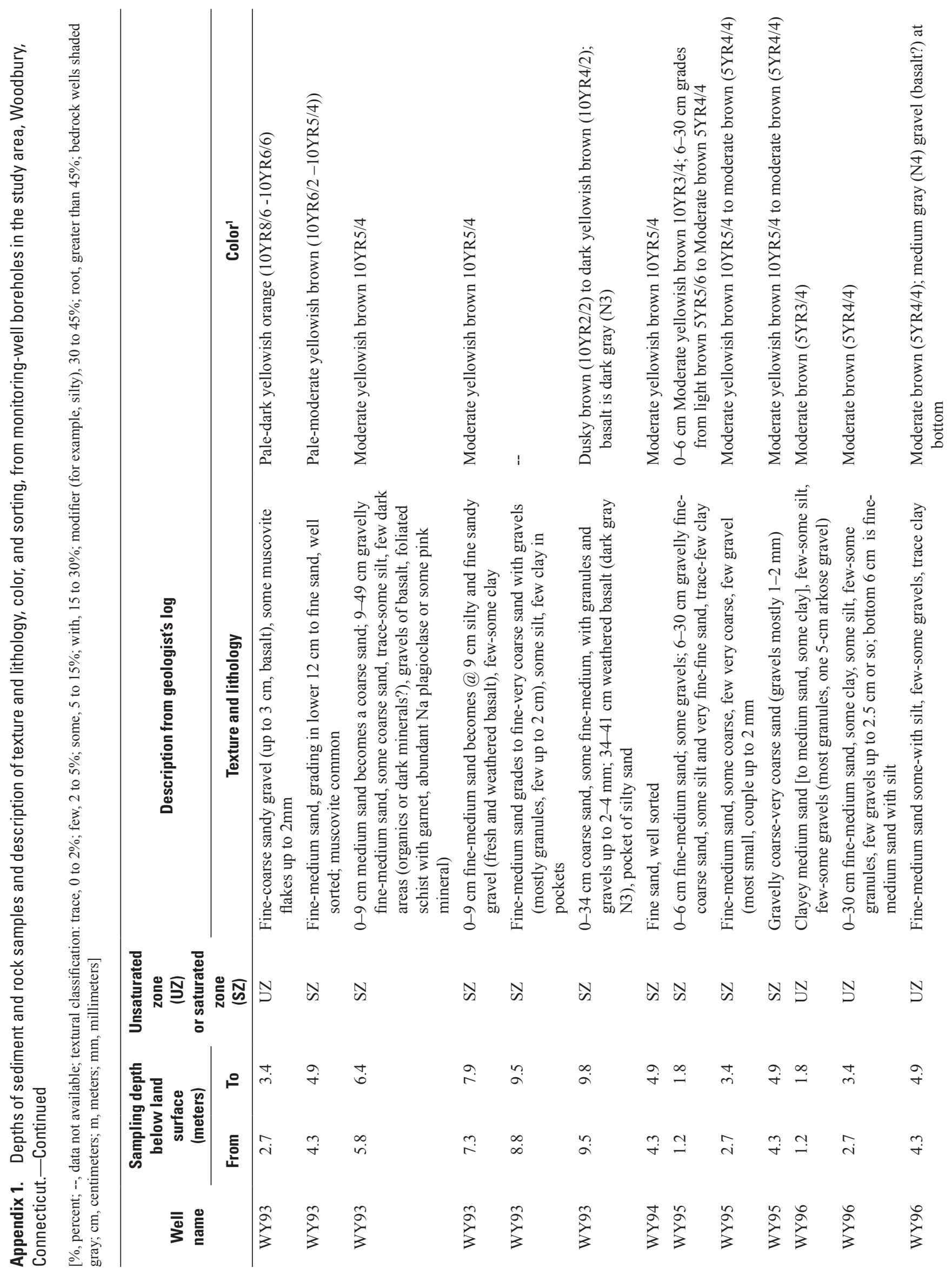




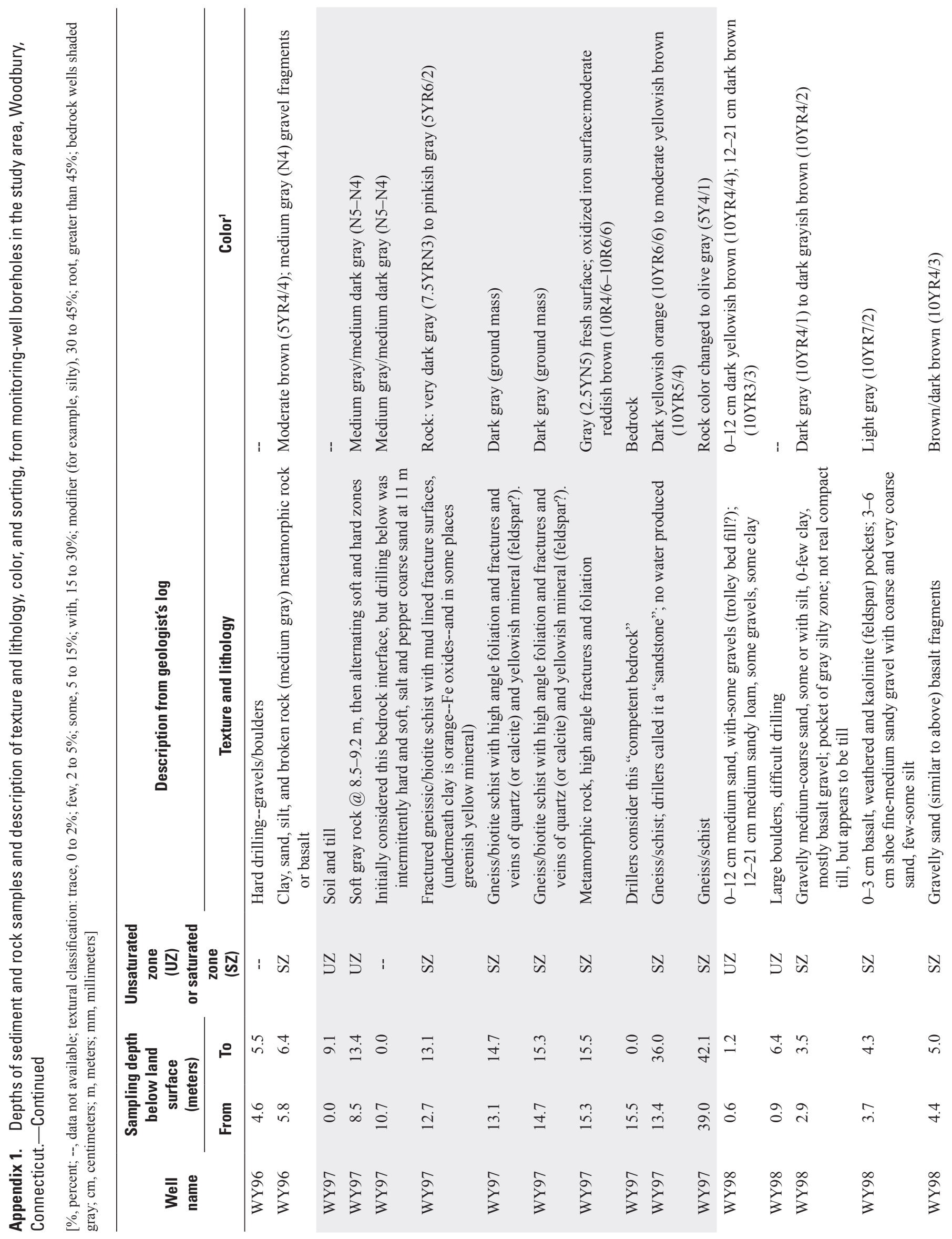




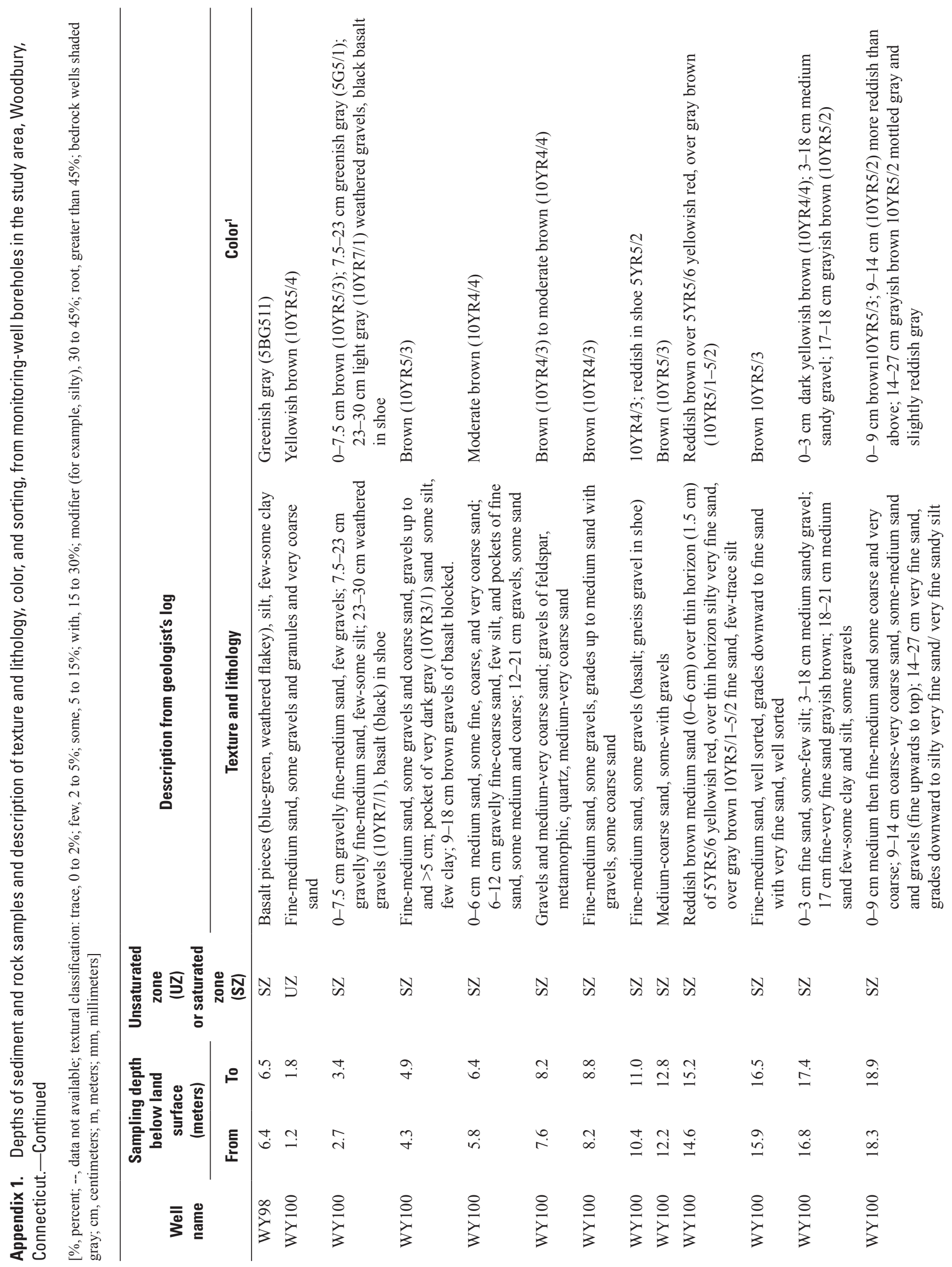




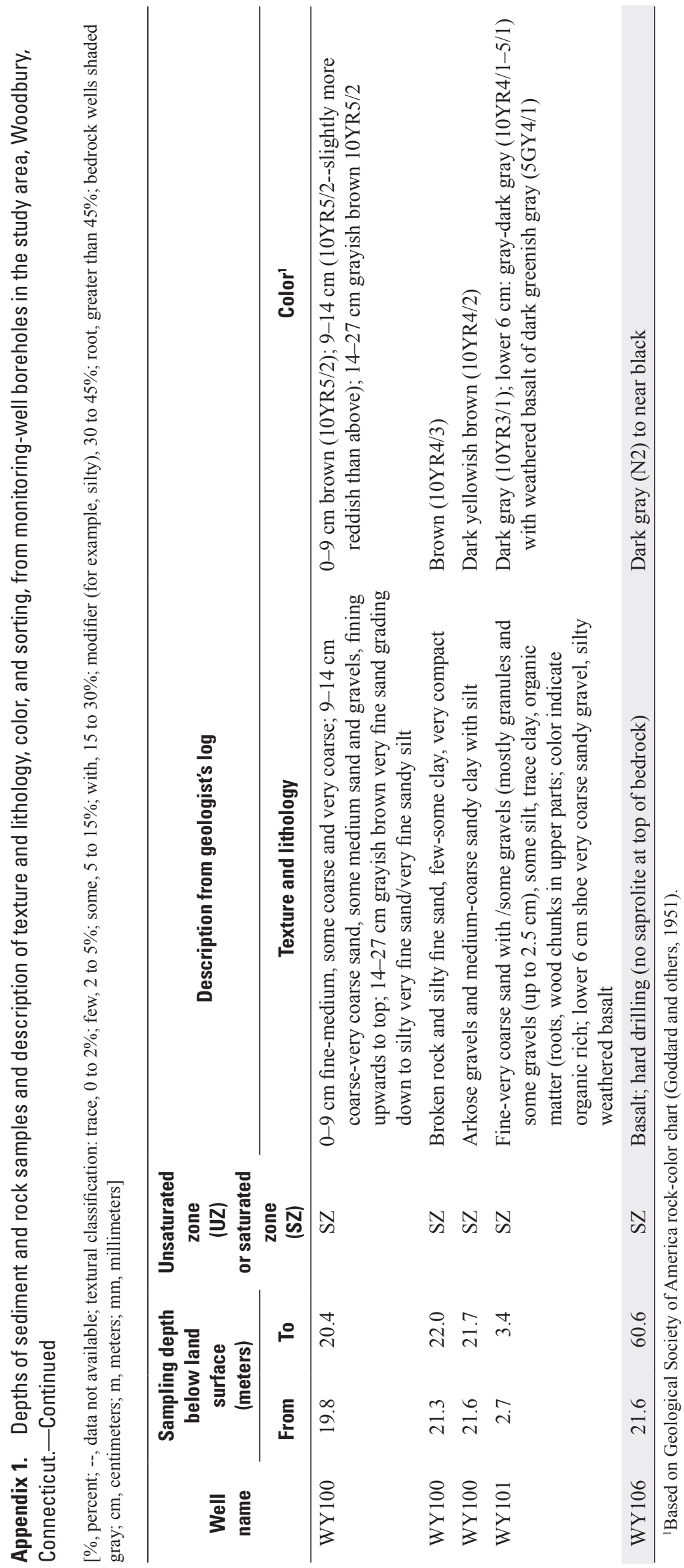




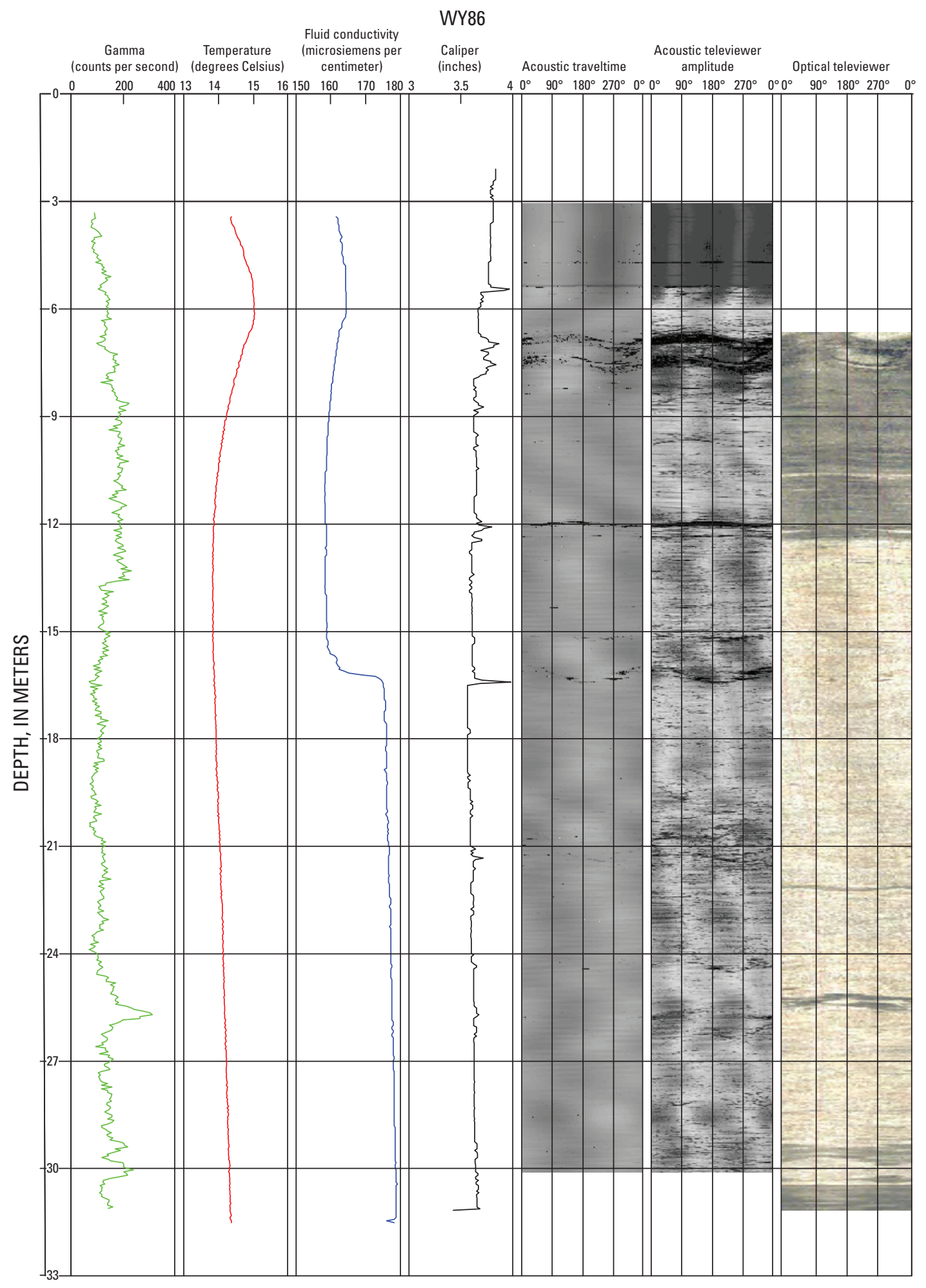

Figure 2-1. Gamma, fluid temperature, fluid conductivity, and caliper logs, and acoustic traveltime, acoustic televiewer amplitude, and optical televiewer images for bedrock monitoring well WY86 in relation to depth in the study area, Woodbury, Connecticut. 


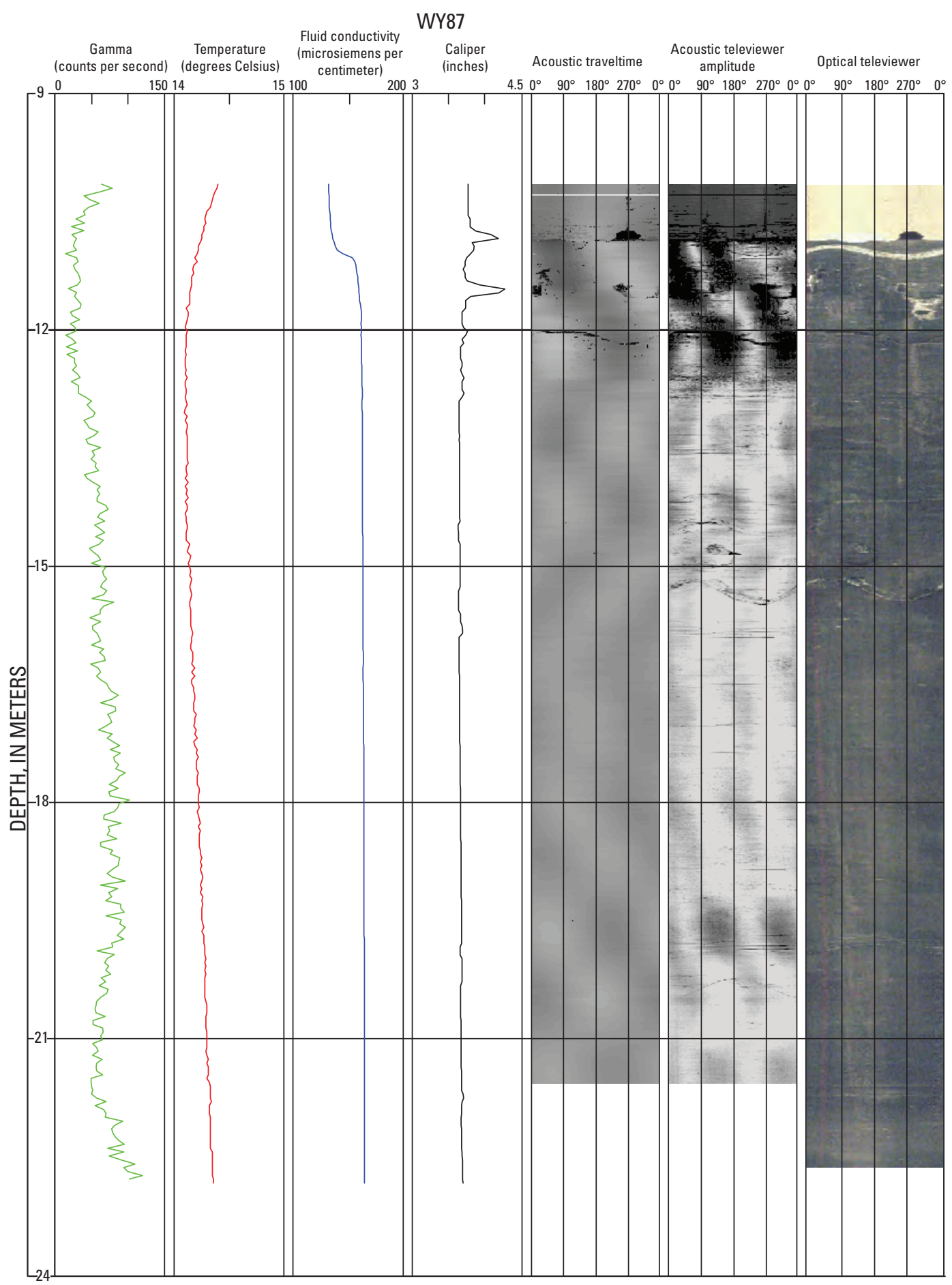

Figure 2-2. Gamma, fluid temperature, fluid conductivity, and caliper logs, and acoustic traveltime, acoustic televiewer amplitude, and optical televiewer images for bedrock monitoring well WY87 in relation to depth in the study area, Woodbury, Connecticut. 


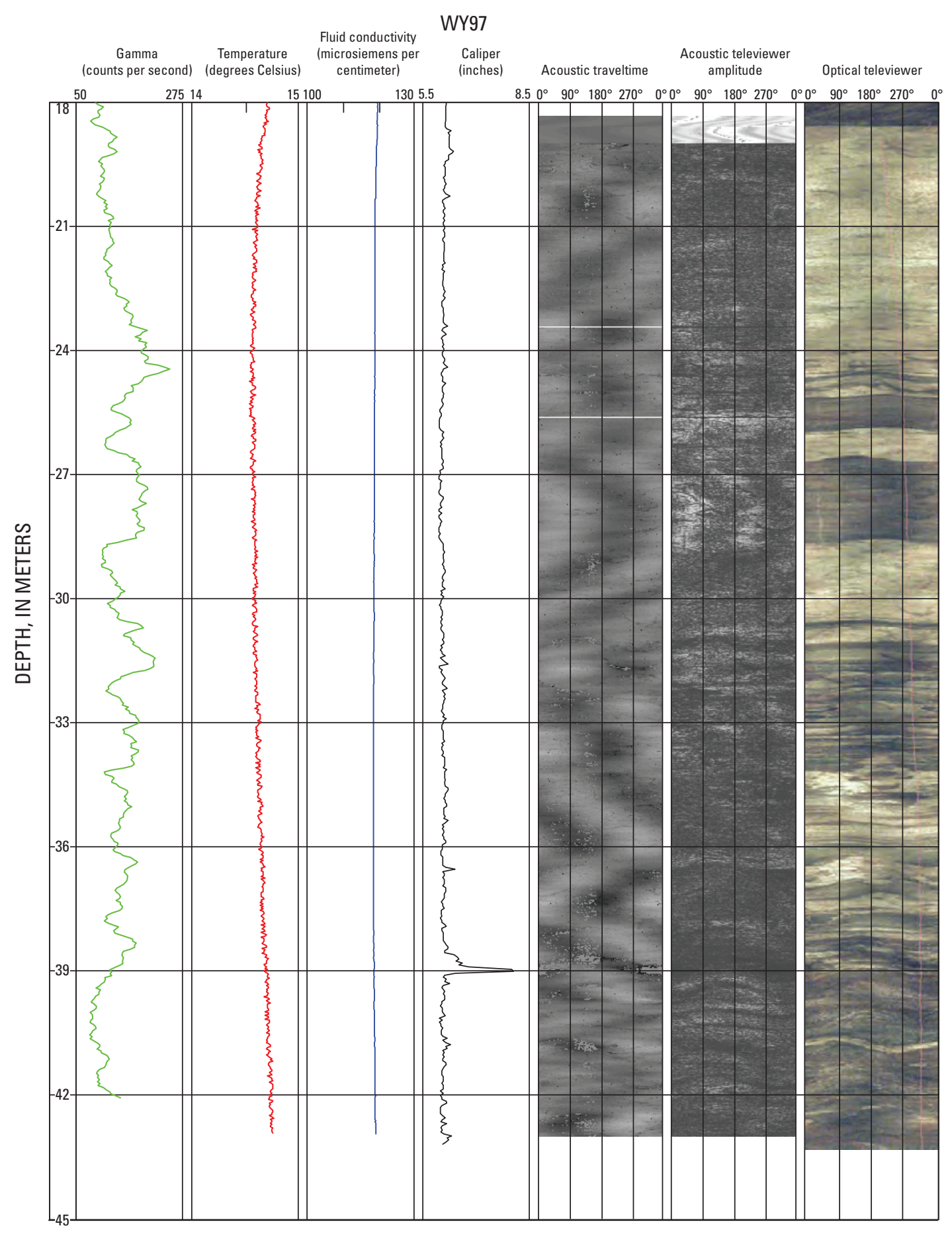

Figure 2-3. Gamma, fluid temperature, fluid conductivity, and caliper logs, and acoustic traveltime, acoustic televiewer amplitude, and optical televiewer images for bedrock monitoring well WY97 in relation to depth in the study area, Woodbury, Connecticut. 


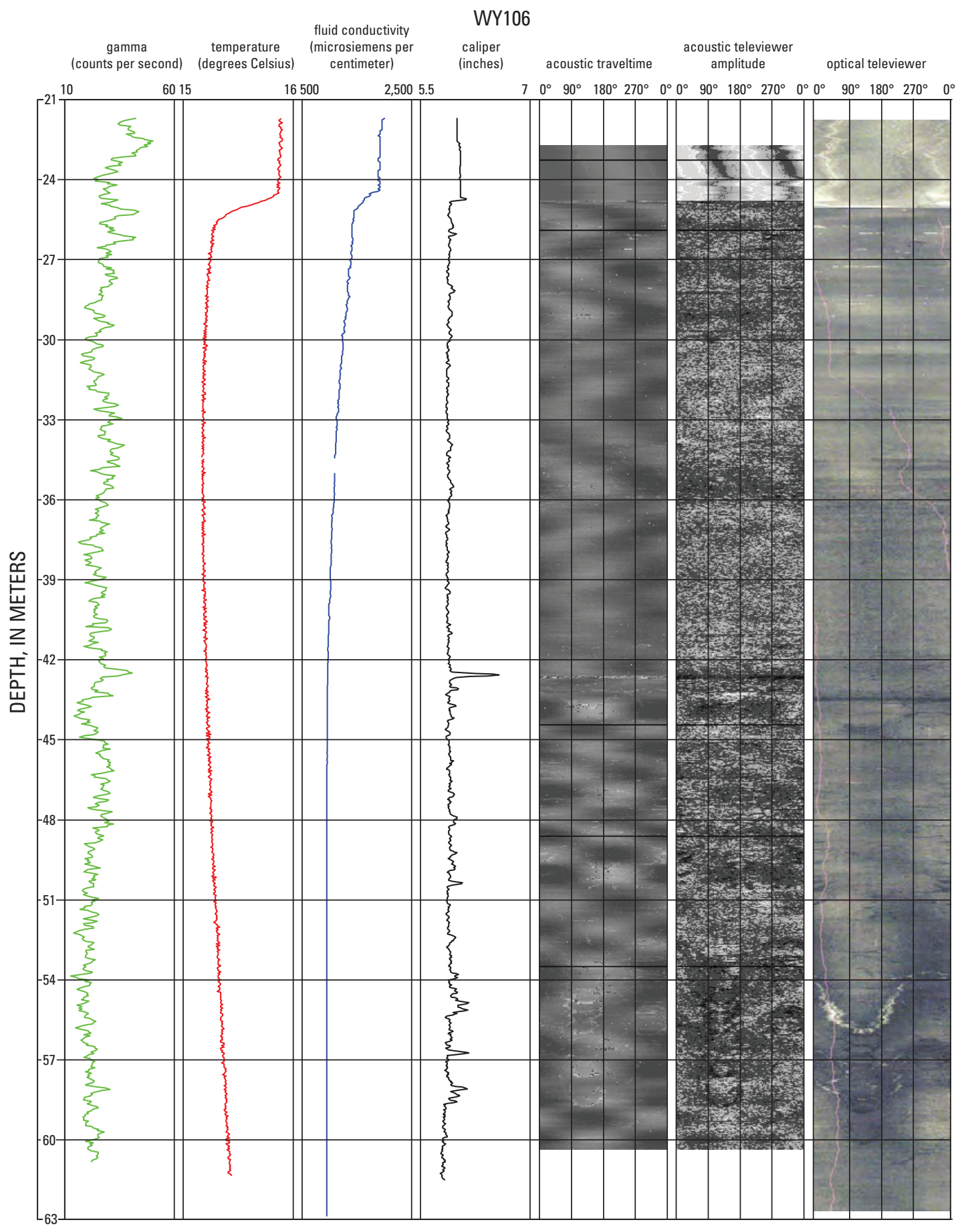

Figure 2-4. Gamma, fluid temperature, fluid conductivity, and caliper logs, and acoustic traveltime, acoustic televiewer amplitude, and optical televiewer images for bedrock monitoring well WY106 in relation to depth in the study area, Woodbury, Connecticut. 


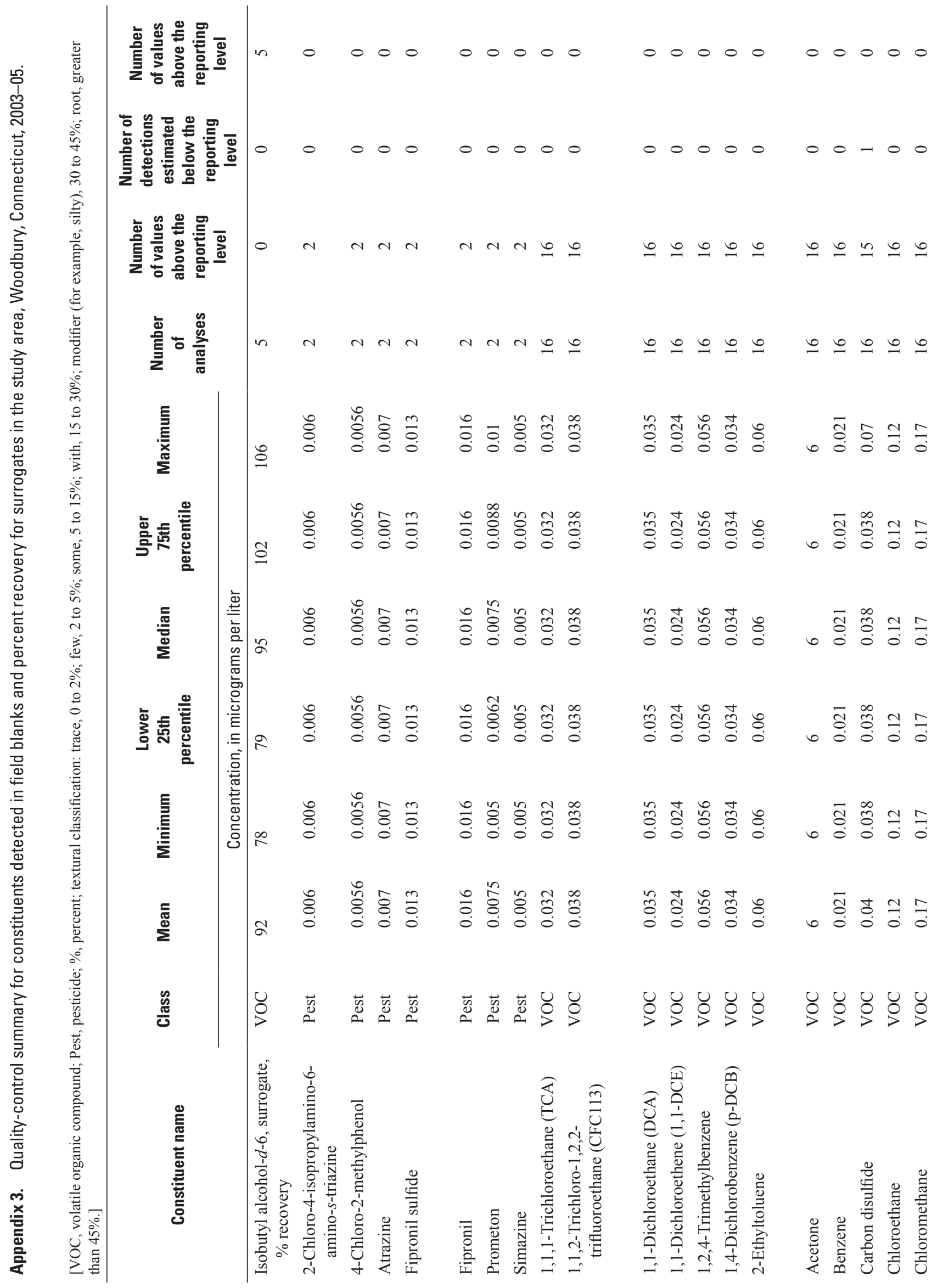




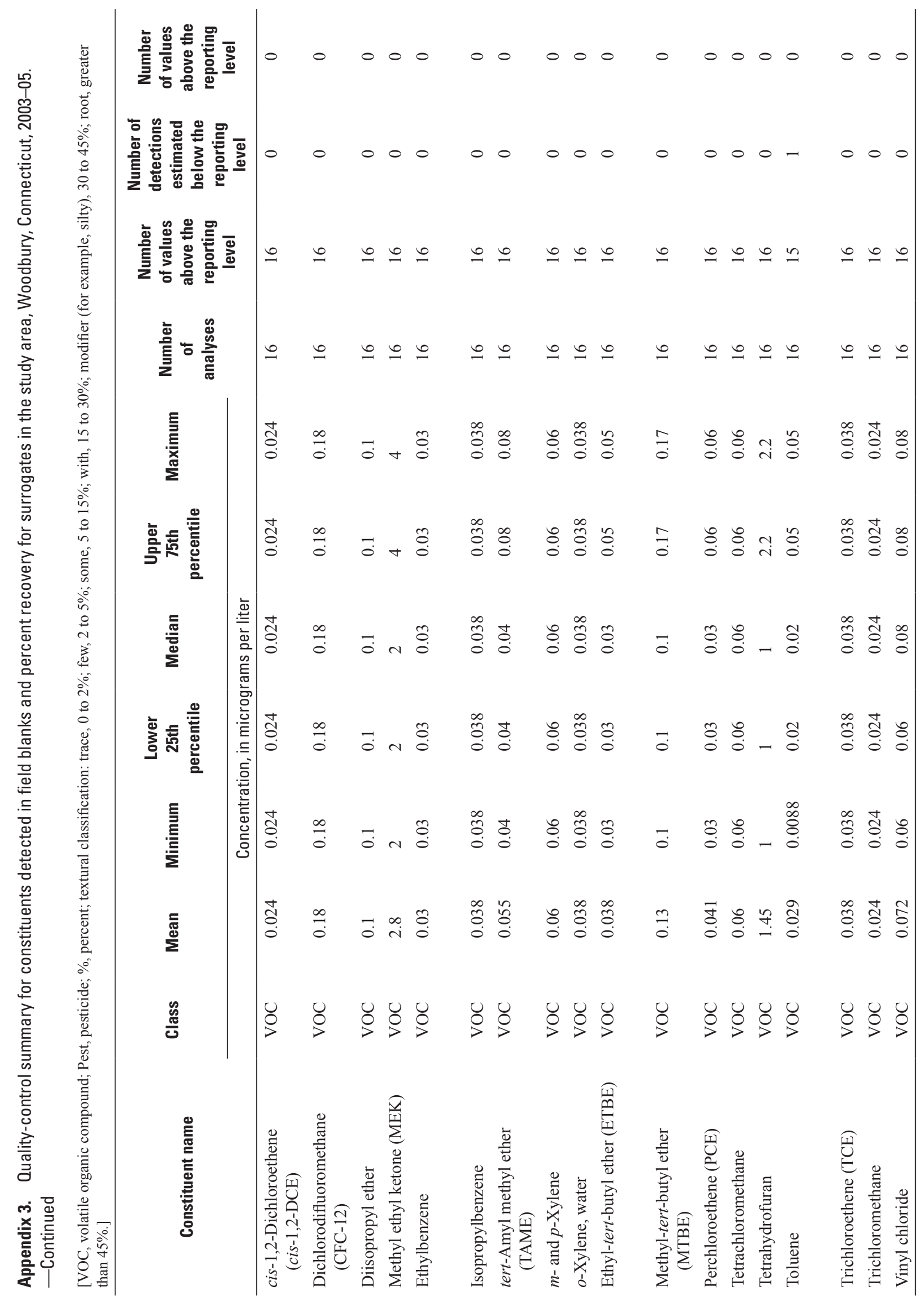




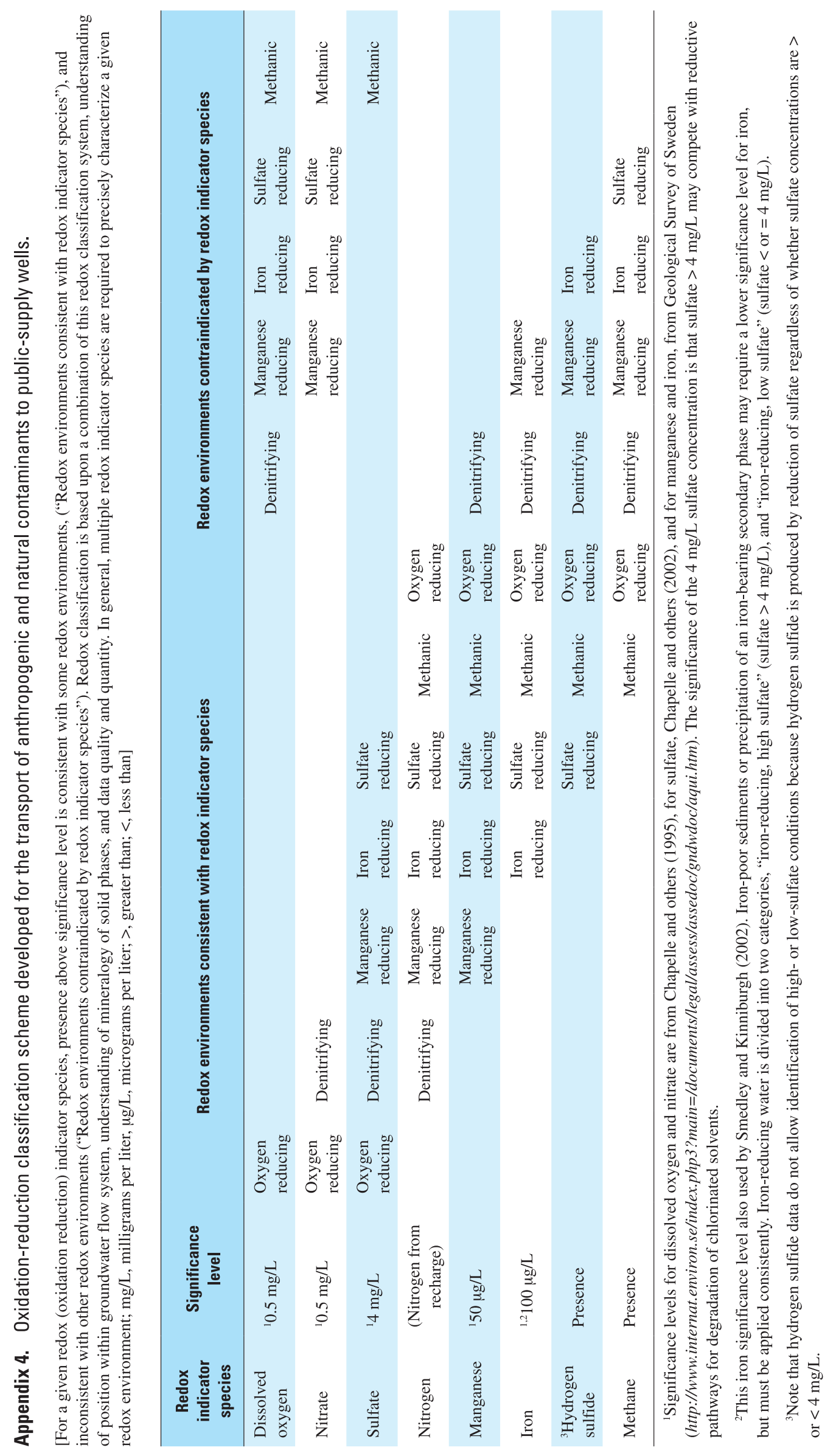


Prepared by the Pembroke and West Trenton Publishing Service Centers.

For more information concerning this report, contact: Director

U.S. Geological Survey

Connecticut Water Science Center 101 Pitkin St.

East Hartford, CT 06108

dc_ct@usgs.gov

or visit our Web site at:

http://ct.water.usgs.gov 


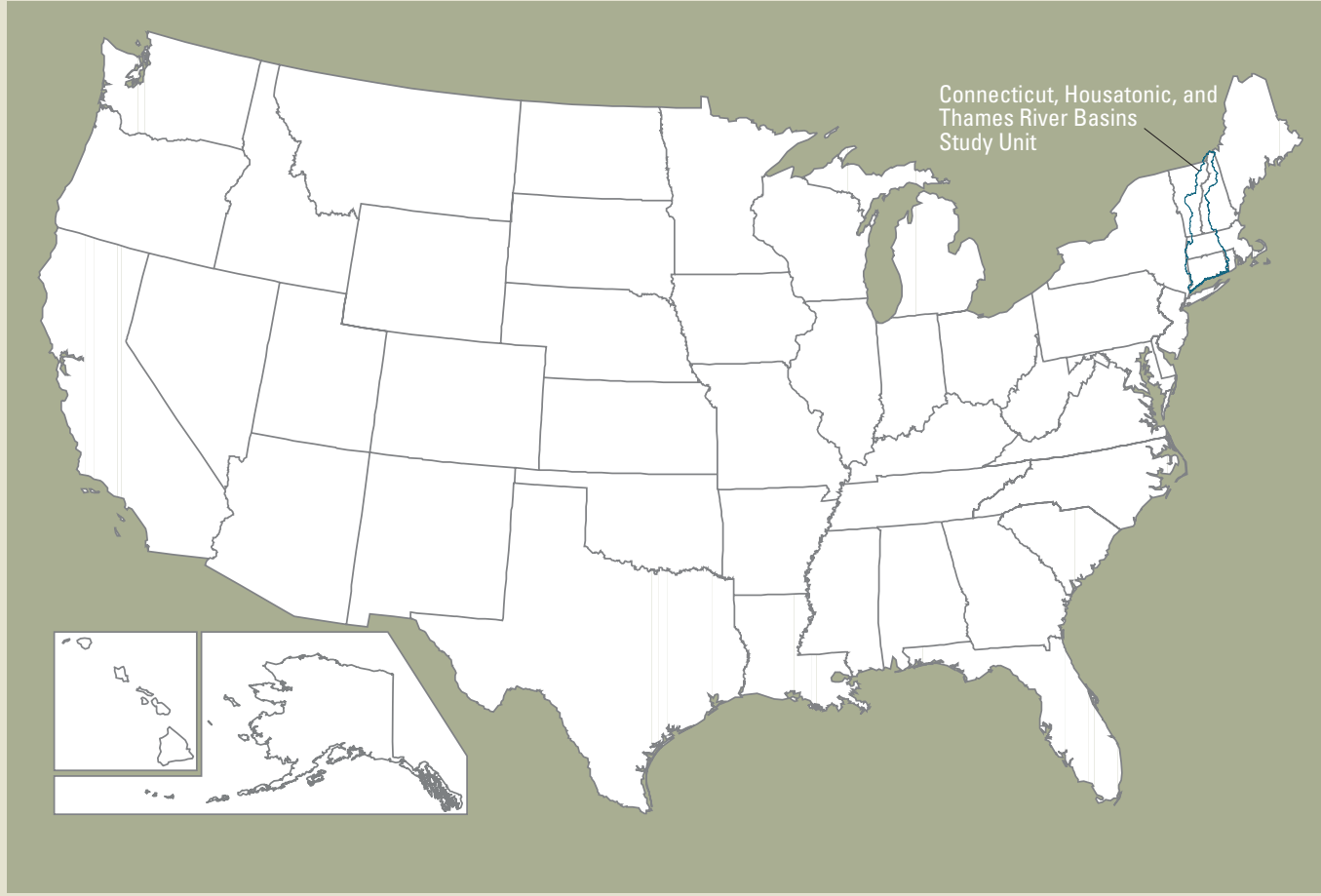

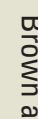

